UNIVERSIDADE DE SÃO PAULO

FFCLRP - DEPARTAMENTO DE BIOLOGIA

PROGRAMA DE PÓS-GRADUAÇÃO EM BIOLOGIA COMPARADA

\title{
Revisão filogenética de Mesoeucrocodylia: irradiação basal e principais controvérsias
}

\section{Felipe Chinaglia Montefeltro}

Tese apresentada à Faculdade de Filosofia, Ciências e Letras de Ribeirão Preto da USP, como parte das exigências para a obtenção do título de Doutor em Ciências, Área: Biologia Comparada.

RIBEIRÃO PRETO - SP 
UNIVERSIDADE DE SÃO PAULO

FFCLRP - DEPARTAMENTO DE BIOLOGIA

PROGRAMA DE PÓS-GRADUAÇÃO EM BIOLOGIA COMPARADA

\title{
Revisão filogenética de Mesoeucrocodylia: irradiação basal e principais controvérsias
}

\author{
Felipe Chinaglia Montefeltro \\ Orientador: Max Cardoso Langer
}

Tese apresentada à Faculdade de Filosofia, Ciências e Letras de Ribeirão Preto da USP, como parte das exigências para a obtenção do título de Doutor em Ciências, Área: Biologia Comparada.

RIBEIRÃO PRETO - SP 


\section{FICHA CATALOGRÁFICA}

Montefeltro, Felipe Chinaglia

Revisão filogenética de Mesoeucrocodylia: irradiação basal e principais controvérsias. Ribeirão Preto, 2013. 285 p. : il. ; $30 \mathrm{~cm}$

Tese de Doutorado, apresentada à Faculdade de Filosofia, Ciências e Letras de Ribeirão Preto/USP. Área de concentração: Biologia Comparada.

Orientador: Langer, Max Cardoso.

1. Crocodyliformes. 2. Mesoeucrocodylia 3. Metasuchia. 4. Notosuchia. 5. Pissarrachampsa. 6. Filogenia 


\section{AGRADECIMENTOS}

Agradeço ao orientador Max Cardoso Langer pelo auxilio e oportunidade de desenvolver o projeto de doutorado sob sua tutela no Laboratório de Paleontologia da FFCLRP. Agradeço também ao orientador Hans C. E. Larsson pela oportunidade e auxilio durante o tempo desenvolvido no Redpath Museum da McGill University.

Agradeço o suporte financeiro deste projeto às instituições: Fundação de Amparo à Pesquisa do Estado de São Paulo (FAPESP), Programa de Pós- Graduação em Biologia Comparada da FFCLRP e Laboratório de Paleontologia da FFCLRP.

Agradeço aos seguintes curadores, e pesquisadores das instituições visitadas pela autorização de análises de material sob sua responsabilidade: Mark Norell e Carl Mehling (AMNH), Bernhard Zipfel e Bruce Rubdge (BPI), Juliana Sayão e Edison Vicente Oliveira (DG-CTG-UFPE), Rodrigo da Rocha Machado (DGM), Marco Brandalise de Andrade (UFRGS), Norbert Micklich (HLMD), Hans C. E. Larsson e Louise Marie Meunier (Redpath Museum), Miguel Ramalho (SGP), Karl Rauscher (IPUW), Max Langer (LPRP), Alejandro Kramarz, Martin Ezcurra e Fernando Novas (MACN), Gladis Retamal (MAU), Diego Pol e Eduardo Ruigomez (MEF), Arturo Muñoz Saraiva e Ricardo Cespedes Paz (MHCN), Lucas Pomi e Marcelo Reguero (MLP), Alexander Kellner, Deise Henriques e Rodrigo Giesta Figueiredo (Museu Nacional), Alberto Garrido (MOZ), Antonio Celso Arruda-Campos, Fabiano Iori e Sandra Tavares (MPMA), Domenica Santos, Flávia Coelho, Jorge Calvo e Juan Porfiri (MUCP), Alberto Barbosa de Carvalho, Hussan Zaher e Paulo Miranda Nascimento (MZUSP), David Evans (ROM), Sheena Kaal (IZIKO), Paul Sereno (UCRC), Felipe Vasconcellos, Ismar Carvalho e Thiago S. Marinho (UFRJ).

Agradeço coletivamente a todos os meus amigos de longa data e recentes, no Brasil e no exterior. Sem dúvidas, eles fizeram esse caminho árduo dos últimos 4 anos mais proveitoso e interessante. Desculpem-me por não citar nominalmente todos, porém não posso 
me abster de citar o imenso companheirismo provido pelos amigos Túlio Nunes, Estevan Eltink e Mario Bronzati. Agradeço também aos amigos de laboratório por promover um ambiente agradável durante as horas de trabalhos diários.

Finalmente, agradeço ao apoio da minha família, em particular, meus pais Valéria, Antônio e minha irmã Suiane, dos quais nunca ouvi uma única palavra que não fosse de incentivo. Chegar ao final deste Doutorado não seria possível sem cada pequeno ato de encorajamento, carinho, suporte e compreensão durante toda minha vida. 


\section{RESUMO}

MONTEFELTRO, F. C. Revisão filogenética de Mesoeucrocodylia: irradiação basal e principais controvérsias. 2013. 285 p. Tese (Doutorado) - Faculdade de Ciências e Letras de Ribeirão Preto, Universidade de São Paulo, Ribeirão Preto, 2013.

Mesoeucrocodylia é um clado bem estabelecido, que circunscreve a maior parte da diversidade taxonômica e morfológica de Crocodyliformes. No entanto, questões amplas relacionadas à sua irradiação basal permanecem controversas. Trabalhos de cunho filogenético tem estabelecido hipóteses altamente contrastantes, em especial relacionadas à validade e inter-relações dos grupos Thalattosuchia, Sebecosuchia, Notosuchia, Peirosauridae e Trematochampsidae. Uma revisão filogenética ampla foi elaborada com o intuito de reavaliar a filogenia de Mesoeucrocodylia de maneira crítica. Para tal, baseou-se no estudo dos táxons envolvidos neste contexto, em especial os possivelmente atribuídos aos cinco subgrupos supracitados, mas também membros das outras principais linhagens de Mesoeucrocodylia, além de grupos externos imediatos ao clado. Os caracteres previamente propostos para este contexto também foram reavaliados, e novos caracteres propostos, visando abarcar a diversidade morfológica total dos diferentes táxons analisados. A matiz táxon-caráter resultante da revisão é composta por 122 táxons e 494 caracteres, que foi submetida à análise de parcimônia através do programa TNT (5000 RAS, TBR, Hold 20). O consenso estrito das 3575 árvores mais parcimoniosas resultantes (MPT) não concorda em sua totalidade com nenhuma hipótese prévia. A nova hipótese filogenética apresenta uma combinação de clados anteriormente propostos e relações pela primeira vez recuperadas. Thalattosuchia foi encontrado como o grupo de Mesoeucrocodylia mais basal, assim, grupo irmão de Metasuchia. Metasuchia, por sua vez, é formado por uma grande dicotomia com Neosuchia em um ramo e Gondwanasuchia no outro. Neosuchia é formado por Stomatosuchidae como ramo mais basal, seguido de Atoposauridae como o grupo irmão de uma politomia. Esta politomia envolve Tethysuchia, Goniopholididae, Bernissartia, e um clado congregando os Neosuchia derivados (Paralligatoridae, Susisuchus e Eusuchia). Gondwanasuchia circunscreve a maior diversidade dos táxons na presente análise sendo formado por uma politomia que envolve Doratodon, Peirosauridae + Trematochampsidae, Sebecidae + Mahajangasuchidae e Notosuchia. Assim, Sebecosuchia foi recuperado parafilético, com Baurusuchidae como um Notosuchia derivado. Adicionalmente, Sebecia, como originalmente proposto, não foi recuperado como uma hipótese mais parcimoniosa em todas as árvores, porém, encontra-se entre os possíveis arranjos dentre as MPT.

Palavras-chave: Crocodyliformes, Mesoeucrocodylia, Metasuchia, Notosuchia, Pissarrachampsa e Filogenia. 


\begin{abstract}
MONTEFELTRO, F. C. The phylogenetic revision of Mesoeucrocodylia: basal radiation and major issues. 2013. 285 p. Tese (Doutorado) - Faculdade de Ciências e Letras de Ribeirão Preto, Universidade de São Paulo, Ribeirão Preto, 2010.

Mesoeucrocodylia is a well established clade encompassing the greatest taxonomic and morphological diversity within Crocodyliformes. However, its basal phylogeny remains poorly understood. Previous works highly disagree on the relationships and validity of an array of basal mesoeucrocodylian groups, particularly Thalattosuchia, Sebecosuchia, Notosuchia, Peirosauridae and Trematochampsidae. The Mesoeucrocodylia basal phylogeny was critically revaluated based on a broad revision. Taxa belonging to the aforementioned subgroups, as well as taxa assigned to other Mesoeucrocodylia major lineages and its immediate outgroups were reanalyzed. Characters previously proposed within this context were also revised and new characters added to cover the morphological diversity within the selected taxa. The final matrix is 122 taxa and 494 character and the parsimony analyses was performed in TNT (5000 RAS, TBR and Hold 20). The strict consensus of the 3575 most parsimonious trees (MPTs) does not fully agree to any of the previous phylogenies. The new analysis depicts a mix of known clades and relationships proposed for the first time. Thalattosuchia is the basal most Mesoeucrocodylia and sister group of Metasuchia. Metasuchia is formed by a dichotomy including Neosuchia on one branch and Gondwanasuchia on the other. Stomatosuchidae is the basal most Neosuchia, followed by Atoposauridae as the sister group of a polytomy encompassing Tethysuchia, Goniopholididae, Bernissartia and a clade of derived neosuchians (Paralligatoridae, Susisuchus and eusuchians). Gondwanasuchia is formed by a basal polytomy including Doratodon, Peirosauridae + Trematochampsidae, Sebecidae + Mahajangasuchidae and Notosuchia. In this sense, Sebecosuchia was not depicted as a monophyletic group and Baurusuchidae was placed derived in the Notosuchia clade. In addition, Sebecia, as original, conceived was not recovered in all of the MPTs however it is a possible result among the MPTs.
\end{abstract}

Keywords: Crocodyliformes, Mesoeucrocodylia, Metasuchia, Notosuchia, Pissarrachampsa e Phylogeny. 


\section{SUMÁRIO}

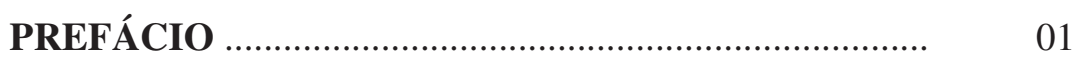

I.

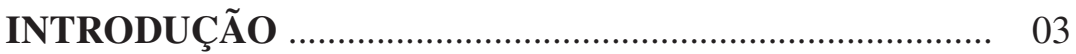

I.I. Principais Controvérsias na Filogenia de Meoseucrocodylia 05

I.I.I. Posicionamento de Thalattosuchia ...................................... 05

I.I.II. Monofilia de Notosuchia .................................................... 07

I.I.III. Monofilia de Sebecosuchia _............................................... 09

I.I.IV. Posição filogenética de Peirosauridae, Mahajangasuchus e Stolokrosuchus ................................................................. 11

I.I.V. Trematochampsidae …................................................. 13

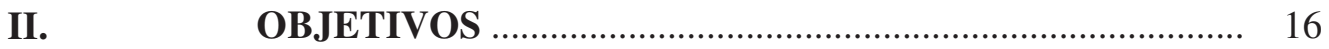

III. MATERIAIS E MÉTODOS ….................................... 17

III.I. Delimitação dos táxons terminais .................................... 17

III.II. Caracteres utilizados na análise ...................................... 18

III.II.I. Compilação de dados e montagem da lista final de

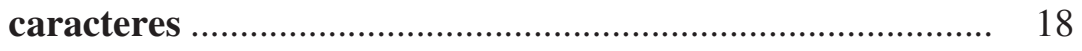

III.II.II Codificação dos táxons .................................................... 21

III.III. Parâmetros da análise filogenética …................................. 21

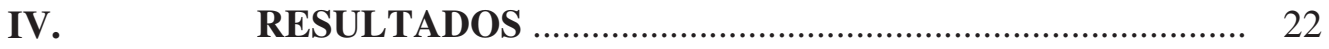

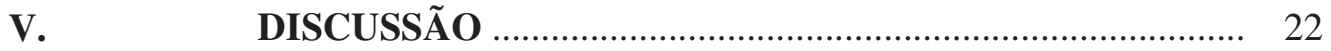

V.I. Topologia do grupo externo ….................................... 25

VI.I.I. Crocodylomorpha não Crocodyliformes ............................ 25

VI.I.II. Crocodyliformes não Mesoeucrocodylia ............................ 26

V.II. Topologia do grupo interno _........................................... 27

V.II.I. Mesoeucrocodylia, Metasuchia e posicionamento de

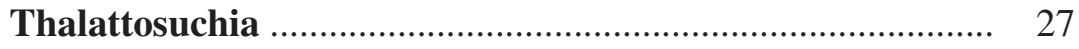

V.II.II. Inter-relações de Thalattosuchia e a posição do Cricosaurus da Colômbia ........................................................ 31

V.II.III. Dicotomia Neosuchia/Gondwanasuchia _............................ 33

V.II.IV. Neosuchia basais ......................................................... 36 
V.II.V. Neosuchia derivados ...................................................... 38

V.II.VI. Inter-relações de Tethysuchia e posição de Khoratosuchus 40

V.II.VII. Inter-relações de Goniopholididae ........................................ 41

V.II.VIII. Paralligatoridae, Susisuchus, Isisfordia e Eusuchia ............. 42

V.II.IX. Inter-relações basais de Gondwanasuchia ........................... 44

V.II.IX.1. Sebecia e as possíveis relações basais de Gondwanasuchia.. 45

V.II.IX.2. Monofilia de Notosuchia e validade de Sebecosuchia .......... 48

V.II.X. Inter-relações do Clado 159 .................................................. 49

V.II.XI. Inter-relações de Peirosauridae + Trematochampsidae ...... 50

V.II.XII. Monofilia de Araripesuchus e Uruguaysuchidae .................. 53

V.II.XIII. Relações basais do clado 147 ............................................... 56

V.II.XIV. Inter-relações dos Notosuchia derivados ............................... 59

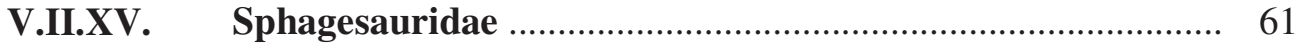

V.II.XVI. Baurusuchia e Baurusuchidae ............................................ 64

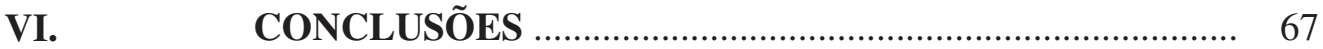

VII. REFERÊNCIAS BIBLIOGRÁFICAS ............................. 70

APÊNDICES .......................................................... 90

APÊNDICE I. TÁXONS TERMINAIS …............................ 90

APÊNDICE II. CARACTERES UTILIZADOS NA ANÁLISE DE PARCIMÔNIA .............................................. 105

APÊNDICE III. MATRIZ TÁXON X CARÁTER ............... 175

APÊNDICE IV. LISTA DE SINAPOMORFIAS ................ 212

REFERÊNCIAS BIBLIOGRÁFICAS ADICIONAIS .......... 233

APÊNDICE V. Montefeltro, F. C., H. C. E. Larsson, \& M. C. Langer. 2011. A New Baurusuchid (Crocodyliformes, Mesoeucrocodylia) from the Late Cretaceous of Brazil and the Phylogeny of Baurusuchidae. PlosONE 6:e21916....... 240 


\section{PREFÁCIO}

O documento aqui apresentado representa a tese submetida ao Programa de Pós-Graduação em Biologia Comparada da FFCLRP como requerimento para a obtenção do título de Doutor em ciências. Esta tese é resultante do projeto "Mesoeucrocodylia do Cretáceo Superior (Formação Vale do Rio do Peixe, Grupo Bauru) de Campina Verde-MG, descrição anatômica e posicionamento filogenético" iniciado junto ao Programa de Pós-Graduação em Biologia Comparada da FFCLRP em 02/03/2009. O projeto contempla dois grandes objetivos, o primeiro, estudar os espécimes coletados no trabalho de campo desenvolvido pelo Laboratório de Paleontologia da FFCLRP em 17-19 de Julho de 2008 (LPRP/USP 0017-0019) na cidade de Campina Verde, MG. O segundo seria desenvolver uma revisão extensa dos táxons e caracteres filogenéticos propostos para Mesoeucrocodylia.

Dado que a análise dos espécimes coletados forma o alicerce para a inserção dos mesmos em um contexto evolutivo, esta faceta do projeto foi desenvolvida primeiramente. A análise do registro fóssil conhecido para Baurusuchidae, incluindo os espécimes LPRP/USP 0018-0019, permitiu o reconhecimento de um novo táxon do grupo circunscrevendo os espécimes supracitados. Do mesmo modo, o estudo da diversidade morfológica de Baurusuchidae fomentou a divisão do estudo filogenético em dois níveis. O primeiro envolve a revisão filogenética dos Baurusuchidae e o segundo as relações dos principais clados de Crocodyliformes.

A descrição do novo táxon, juntamente com a revisão filogenética de Baurusuchidae foram finalizadas em 2011 e agrupadas em um artigo denominado "A new baurusuchid (Crocodyliformes, Mesoeucrocodylia) from the Late Cretaceous of Brazil and the Phylogeny of Baurusuchidae" de autoria de Felipe Chinaglia Montefeltro com co-autoria de Hans C.-E. Larsson e Max Cardoso Langer publicado no dia 13 de Julho de 2011 no periódico 
PLoS One. Tanto o corpo do artigo quanto seu material suplementar representam uma parte essencial do desenvolvimento do projeto contendo grande parte dos resultados obtidos durante o período de vigência do Doutorado. O artigo trata da descrição detalhada do táxon nomeado como Pissarrachampsa sera, bem como da primeira filogenia centrada em Baurusuchidae e a contextualização estratigráfica da região de Campina Verde.

$\mathrm{O}$ artigo foi publicado na língua inglesa e considero que sua tradução despenderia um gasto de energia e tempo desnecessário. Sendo assim, o artigo e seu material suplementar foram incluídos como o Apêndice $\mathrm{V}$ na presente tese. Consequentemente, a revisão mais abrangente dos táxons de Crocodyliformes e caracteres utilizados para definir suas relações filogenéticas compõem a maior parte do corpo deste documento (páginas 3-239). 


\section{INTRODUÇÃO}

As 23 espécies viventes de Crocodyliformes (sensu Benton \& Clark 1988, Clark 1994) são componentes de irradiações relativamente recentes deste grupo, que tem sua história traçada desde o Triássico Superior. A hipótese corrente sobre as relações filogenéticas de Crocodyliformes agrupa as espécies viventes em um clado relativamente pouco inclusivo denominado Crocodylia (sensu Benton \& Clark 1988, Brochu et al. 2009). O registro fóssil de Crocodylia é notável, se estendendo por todos os continentes durante o Neógeno (Brochu 2003) e englobando formas díspares (ex: Brochu \& Storrs 2012, Mead et al. 2002, Boquetin \& Souza-Filho 1990, Rossman 2000). No entanto, em uma perspectiva mais abrangente, a diversidade taxonômica e morfológica de Crocodylia é menos expressiva em comparação aos Crocodyliformes não Crocodylia (Figura 1). Estes, não só apresentam uma maior diversidade taxonômica, mas também uma disparidade morfológica mais marcante. Diversidade tal expressa em uma miríade de formas corporais e hábitos de vida (ex.: Sereno \& Larsson 2009, Krause et al. 2010, Young et al. 2011ab, Holliday \& Gardner 2012, Pol et al. 2012).

As duas últimas décadas foram particularmente prolíficas no que tange o estudo dos Crocodyliformes não Crocodylia. Tal avanço está ligado à descrição de novas formas de morfologia única (ex.: Larsson \& Gado 2000, Salisbury et al. 2006, Ösi et al. 2007, Marinho \& Carvalho 2009, O’Connor et al. 2010), além da descrição de novos espécimes e reavaliação de táxons previamente descritos (Gow 2000, Larsson \& Sues 2007, Simons \& Buckley 2009, Jouve 2009, Kley et al. 2010, Young et al. 2012, Martinelli et al. 2012). Foi também nas últimas duas décadas, que técnicas de sistemática filogenética começaram a ser aplicadas em um contexto amplo para Crocodyliformes (ex.: Clark 1994, Wu et al. 1994ab, 1997). Desde então mais de 90 trabalhos foram publicados contendo análises filogenéticas de 
Crocodyliformes não Crocodylia (números atualizados de Bronzati et al. 2012) e consensos pontuais podem ser identificados.

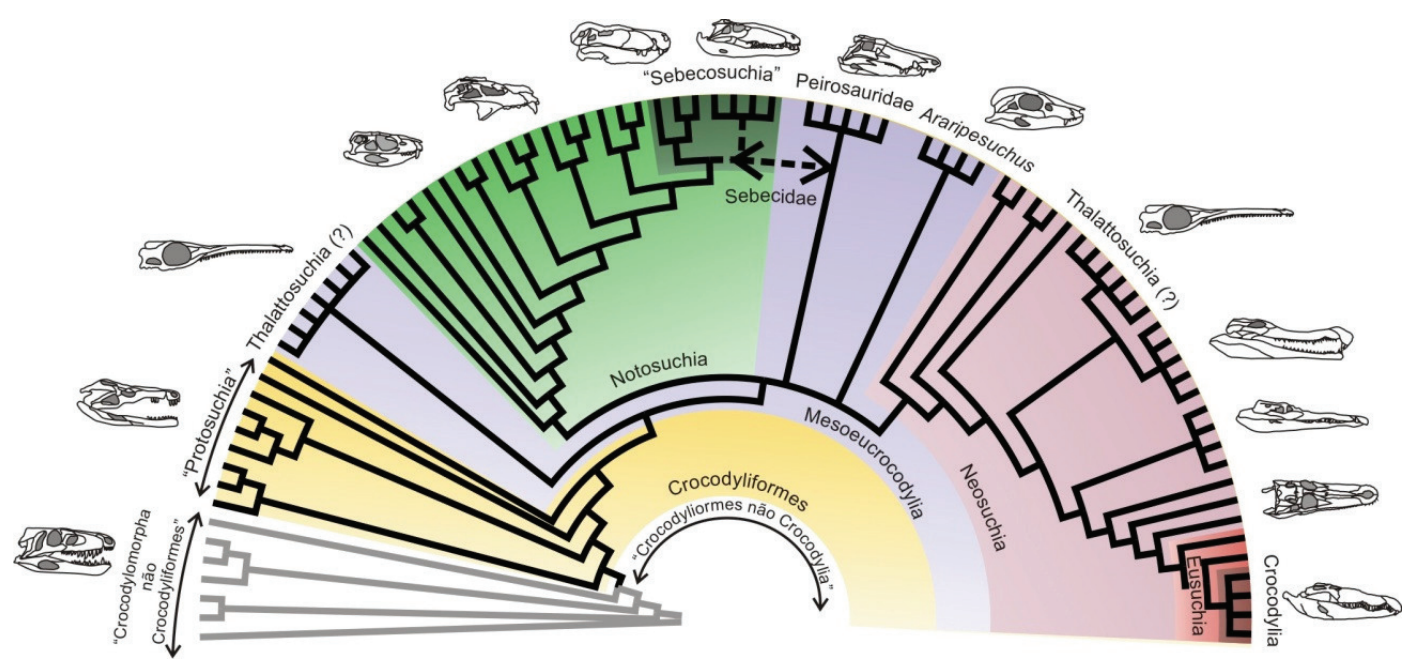

Figura 1. Sumário das relações filogenéticas consensuais de Crocodyliformes baseado em hipóteses previas.

A proposição da parafilia dos tradicionais "Protosuchia" (Brown 1934) e "Mesosuchia" (Huxley 1875) estão entre os pontos principais em que a aplicação da sistemática filogenética teve maior impacto no entendimento das relações dos Crocodyliformes. A aplicação do método também demonstrou consistentemente a presença do grupo monofilético Mesoeucrocodylia (mesmo que com abrangências variáveis), que engloba os tradicionais "Mesosuchia" e Eusuchia. Neste contexto, os "protossúquios" são posicionados, como grupos irmãos sucessivos de Mesoeucrocodylia (Figura 1).

Em Mesoeucrocodylia, poucos clados podem ser consensualmente reconhecidos, o mais evidente é a presença de um subgrupo monofilético denominado Neosuchia (Benton \& Clark 1988). Este engloba, além dos Eusuchia, os mais derivados Mesoeucrocodylia anteriormente incluídos em "Mesosuchia". Eusuchia compreende, além de Crocodylia, certos grupos exclusivamente fósseis (Figura 1). Este arranjo geral pode ser encontrado em 
virtualmente todas as análises filogenéticas de Crocodyliformes (veja Wu et al. 1994ab, 1997, para contrapontos). Não obstante, outras questões permanecem altamente controversas, em especial as relacionadas à irradiação basal de Mesoeucrocodylia envolvendo Thalattosuchia, Sebecosuchia, Notosuchia, Peirosauridae e Trematochampsidae.

\section{I.I. Principais Controvérsias na Filogenia de Meoseucrocodylia}

Para a delimitação dos problemas, propõe-se apresentar as controvérsias sobre a filogenia dos Mesoeucrocodylia basais de forma inteligível. Porém, em muitos casos, a discussão aprofundada sobre um ponto transcende os limites taxonômicos e acaba por ter implicações quase fractais. Para facilitar a exposição dos problemas, nem todas as contradições serão apresentadas, entre elas, as que envolvem o posicionamento de táxons específicos. Assim, foram privilegiadas questões mais amplas, com impacto geral no entendimento da evolução de Crocodyliformes. No entanto, variações de menor escala ocorrem praticamente em todos os níveis da filogenia.

\section{I.I.I. Posicionamento de Thalattosuchia}

Os Thalattosuchia (Fraas 1901) compreendem um dos grupos de Crocodyliformes com plano de corpo mais modificado (Figura 2). Os táxons do grupo são adaptados ao ambiente aquático, mais notavelmente o subgrupo Metriorhynchidae (Fitzinger 1843), que foram os únicos arcossauros completamente adaptados à vida aquática (Langston 1973, Gasparini et al. 2006, Young et al. 2010, 2011ab). O registro temporal dos Thalattosuchia abrange mais de 50 milhões de anos (Sinemuriano-Valanginiano) com um pico de diversidade durante o Jurássico 
Médio e Superior. Neste período, os representantes do grupo são componentes frequentes nas comunidades marinhas em várias regiões do globo (Gasparini et al. 2006, Young et al. 2010).
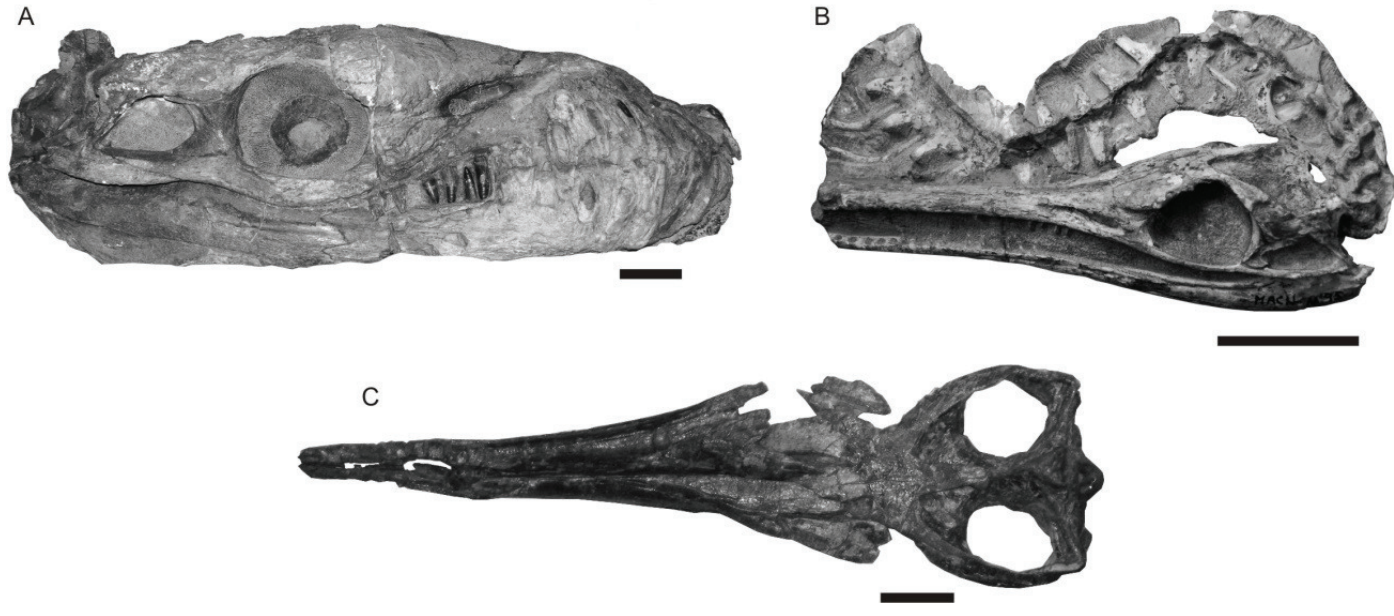

Figura 2. Exemplo de táxons atribuídos a Thalattosuchia. A- Vista lateral direita do crânio de Dakosaurus andiniensis (MOZ 6146P), B- Vista lateral do crânio de pós-crânio parcial de Cricosaurus araucanensis (MACN-N 95) e C- Vista dorsal do crânio do Cricosaurus Colômbia (RM sem número). Barra de escala $5 \mathrm{~cm}$.

A existência de um grupo natural englobando as espécies de Thalattosuchia já era bem sedimentada na literatura, e a sistemática filogenética sustenta consistentemente a sua monofilia (ex.: Buffetaut 1982a, Benton \& Clark 1988, Müller-Towe 2005, Pol \& Gasparini 2009, Jouve 2009, Cau \& Fantini 2010, Young et al. 2010, 2012, Leardi et al. 2012). Recentemente, os Metriorhynchidae foram alvo de intensa revisão, com eventuais rearranjos taxonômico-filogenéticos (ex: Young \& Andrade 2009, Young et al. 2010, 2011ab, 2012). Nesse contexto, os clados Geosaurinae e Metriorhynchinae englobam a maior diversidade dos Metriorhynchidae, que por sua vez, engloba a maioria dos táxons de Thalattosuchia inseridos em análises filogenéticas.

Se por um lado a monofilia do clado é bem sustentada, o posicionamento de Thalattosuchia dentre os Crocodyliformes é um ponto de debate recorrente (Benton \& Clark 
1988, Clark 1994, Buckley \& Brochu 1999, Pol \& Gasparini 2009, Jouve 2009). Benton \& Clark (1988), em seu trabalho seminal sobre a evolução de Crocodyliformes, discutem três possíveis posicionamentos para Thalattosuchia. A hipótese mais parcimoniosa dispõe o clado dentro de Neosuchia e proximamente relacionados a outros táxons de rostro alongado Dyrosaurus e Pholidosaurus (Figura 1, Tethysuchia, sensu Andrade et al. 2011). No entanto, esta hipótese foi preterida em relação às outras duas. O descarte da hipótese mais parcimoniosa foi justificado pela natureza eco-funcional dos caracteres suportando este posicionamento. As outras duas hipóteses menos parcimoniosas, porém preferidas dos autores, apresentam Thalattosuchia como Crocodyliformes basais. Nestas hipóteses, Thalattosuchia ou representa o grupo irmão de todos os demais Crocodyliformes, ou grupo irmão dos demais Mesoeucrocodylia (Figura 1). Em trabalhos subsequentes, a hipótese posicionando Thalattosuchia como grupo irmão dos demais Crocodyliformes só é recuperada em análises exploratórias (Pol \& Gasparini 2009, Jouve 2009). No entanto, as outras duas hipóteses são repetidamente refutadas e corroboradas na literatura (ex.: Buckley et al. 2000; Sereno et al. 2001, 2003; Pol 2003, Pol \& Apesteguia 2005, Turner \& Calvo 2005; Turner 2006; Larsson \& Sues 2007; Andrade \& Bertini 2008ab, Turner \& Sertich 2010, Sereno \& Larsson 2009, Pol et al. 2004, 2009, 2012, Young et al. 2012).

\section{I.I.II. Monofilia de Notosuchia}

Notosuchia foi erigido por Gasparini (1971) como infra-ordem composta por Notosuchus terrestris (Woodward 1896), Uruguaysuchus aznarezi (Rusconi 1933), U. terrai (Rusconi 1933) e Araripesuchus gomesi (Price 1959), circunscrevendo uma unidade morfológica de formas de pequeno porte essencialmente terrestres, provenientes de sedimentos cretácicos gonduânicos (Figura 3). Contudo, com a descrição de novos táxons e a inclusão de 
notosúquios em análises filogenéticas amplas, a delimitação taxonômica do grupo mostrou-se inconsistente. Nesta tese, o termo "Notosuchia" será aplicado (entre aspas) para se referir ao conceito histórico relacionado ao grupo, enquanto Notosuchia será utilizado para designar um clado que frequentemente incluirá táxons não tradicionalmente associados ao grupo.

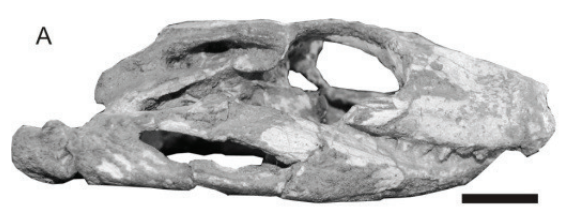

D

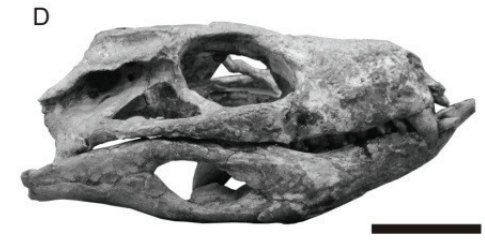

B

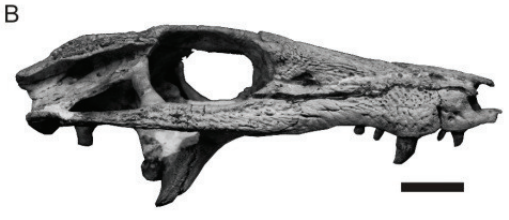

E

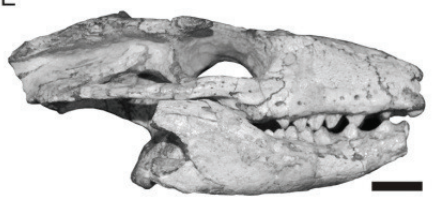

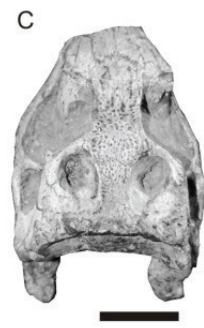

Figura 3. Exemplo de táxons atribuídos a "Notosuchia". A- Vista lateral direita do crânio de Notosuchus terrestris (MUCP-PV 137), B- Vista lateral direita do crânio de Araripesuchus wegneri (MNN GAD 20), C- Vista dorsal do crânio de Araripesuchus patagonicus (MUCPv 269), E- Vista lateral direita do crânio de Mariliaschus amarali (UFRJ-D-106-R), e E- Vista lateral direita do crânio de Sphagesaurus montealtensis (MPMA 15001/90). Barra de escala $2 \mathrm{~cm}$.

Em linhas gerais, "Notosuchia" e Sebecosuchia (em suas totalidades, ou em parte) formam o clado Notosuchia de Sereno et al. (2001). Na maior parte das análises, os Sebecosuchia formam um grupo monofilético, enquanto os "Notosuchia" são encontrados como grupos irmão sucessivos do mesmo. Exceções são encontradas em Turner \& Calvo (2005), Turner (2006) e Fiorelli \& Calvo (2007), em que os "Notosuchia" formam o grupo irmão de Sebecosuchia.

A parte da inclusão de Sebecosuchia, por completo ou parcialmente em Notosuchia, outro ponto de particular discussão repousa sobre Araripesuchus. Algumas análises o consideram aproximado ao clado Neosuchia (Ortega et al. 2000, Buckley et al. 2000, Tykoski et al. 2002, Company et al. 2005, Turner \& Calvo 2005, Turner 2006, Andrade \& Bertini 
2008a, Young \& Andrade 2009, Smith et al. 2010), mas a maioria das análises aponta o gênero como um Notosuchia basal. Nestas hipóteses, Araripesuchus foi alternativamente recuperado como grupo irmão dos demais Notosuchia (Pol \& Norell 2004ab, Pol et al. 2004, Pol \& Apesteguia 2005, Zaher et al. 2006, Turner \& Buckley 2008, Fiorelli \& Calvo 2008, Leardi \& Pol 2009, O’Connor et al. 2010, Riff \& Kellner 2011, Nascimento \& Zaher 2011, Iori \& Carvalho 2011), como uma entidade parafilética na base do clado (Sereno \& Larsson 2009, Turner \& Sertich 2010), ou formando Uruguaysuchidae, juntamente com Uruguaysuchus (Soto et al. 2011, Pol \& Powell, 2011). Uruguaysuchidae (incluindo Araripesuchus) pode, ainda, ser grupo irmão de Peirosauridae (Pol et al. 2012). Outras análises posicionam Araripesuchus como mais derivado no clado Notosuchia (Gomani 1997, Fiorelli \& Calvo 2007, Andrade et al. 2011). Finalmente, Young et al. (2012), posicionam Araripesuchus como grupo irmão da dicotomia Notosuchia - Neosuchia.

Algumas propostas filogenéticas não reconhecem os "Notosuchia" compondo um clado juntamente com Sebecosuchia (na totalidade ou em parte). Estas análises tem os resultados muito discrepantes devido à amostragem taxonômica singular de cada uma delas (ver Clark 1994, Wu \& Sues 1996, Buckley \& Brochu 1999, Carvalho et al. 2004, Jouve et al. 2006 e Jouve 2009). Assim, a correspondência entre os clados recuperados e a comparação dos resultados fica intangível.

\section{I.I.III. Monofilia de Sebecosuchia}

Sebecosuchia foi originalmente proposto baseado em Sebecus icaeorhinus (Simpson 1937), sendo Baurusuchus pachecoi prontamente associado ao grupo (Price 1945, Colbert 1946, Buffetaut 1982b). Sebecosuchia é historicamente formado por Sebecidae (Simpson 1937, Figura 4) e Baurusuchidae (Price 1945, Figura 5), constituindo um grupo de Crocodyliformes 
carnívoros, terrestres, de médio porte, com rostro alto e dentição zifodonte (sensu Prasad \& Lapparent de Broin 2002). Sob essa perspectiva, Sebecosuchia abrange uma amplitude temporal do Cretáceo Superior (Baurusuchidae) ao Neógeno (Sebecidae) com os registros mais significativos provenientes de depósitos sul americanos (Woodward 1896, Price 1945, Gasparini et al. 1993, Campos et al. 2001, Carvalho et al. 2005, Turner \& Calvo 2005, Paolillo \& Linares 2007, Montefeltro et al. 2011, Pol \& Powell 2011). Todavia, possíveis representantes do grupo são encontrados no Cretáceo Superior do Paquistão, Áustria e Espanha; além do Eoceno da Argélia, França, Alemanha e Portugal (Antunes 1975, Buffetaut 1989, Ortega et al. 1996, Rossman et al. 2000, Wilson et al. 2001, Company et al. 2005).

Como mencionado acima, Sebecosuchia aparece como um grupo monofilético derivado do clado Notosuchia na maioria das análises filogenéticas de Crocodyliformes (Pol \& Norell 2004ab, Pol et al. 2004, Pol \& Apesteguia 2005, Zaher et al. 2006, Turner \& Buckley 2008, Fiorelli \& Calvo 2008, Leardi \& Pol 2009, O’Connor et al. 2010, Turner \& Sertich 2010, Riff \& Kellner 2011, Nascimento \& Zaher 2011, Iori \& Carvalho 2011, Soto et al. 2011, Pol et al. 2012), mas a parafilia de Sebecosuchia foi aventada desde os primórdios das análises filogenéticas de Crocodyliformes, sendo corroborada pontualmente em diferentes contextos (Clark 1994, Wu et al. 1997, Carvalho et al. 2004, Larsson \& Sues 2007, Andrade \& Bertini 2008a, Young \& Andrade 2009, Sereno \& Larsson 2009, Montefeltro et al. 2011). Nestes casos, mesmo quando Sebecosuchia é parafilético, em geral, Baurusuchidae se mantém em Notosuchia (Andrade \& Bertini 2008a, Young \& Andrade 2009, Sereno \& Larsson 2009, Montefeltro et al. 2011). 


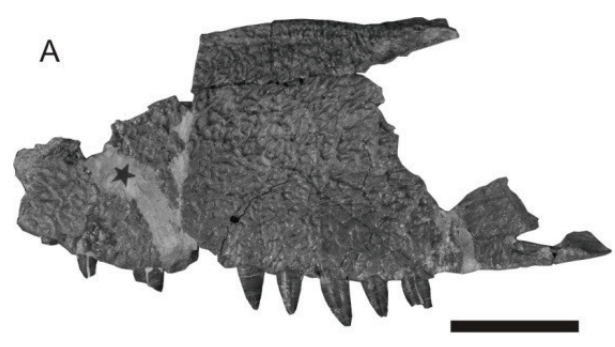

B
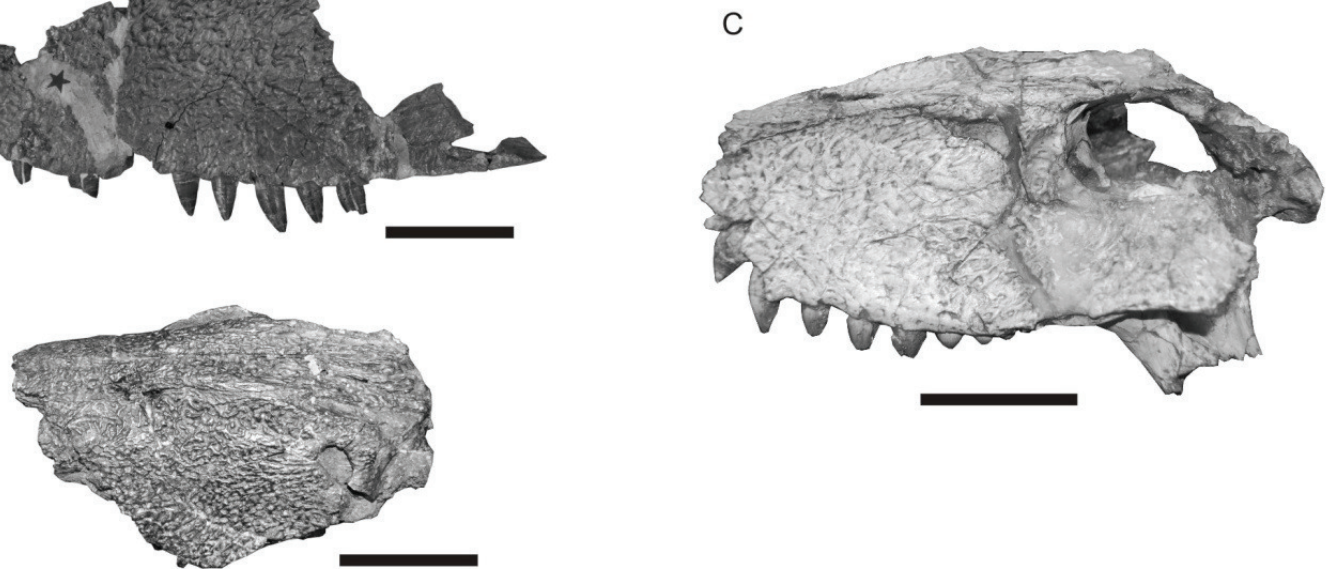

Figura 4. Exemplo de táxons atribuídos a Sebecidae. A- Vista lateral esquerda da maxila esquerda de Sebecus icaeorhinus (AMNH 3160), B- Vista lateral direita do crânio parcial de Bergisuchus dietrichbergi (Me 7003 HLD, invertido) e C- Vista lateral esquerda do crânio de Sebecus querejazus (MHCN-P 3701). Barra de escala $5 \mathrm{~cm}$.

O posicionamento de Sebecidae, normalmente representado nas análises somente por seu táxon tipo, Sebecus icaeorhinus, é mais controverso. Em certas análises, S. icaeorhinus é incluído em Neosuchia (Larsson \& Sues 2007, Andrade \& Bertini 2008a, Young \& Andrade 2009, Sereno \& Larsson 2009, Andrade et al. 2011, Holliday \& Gardner 2012), em particular, sua aproximação à Peirosauridae, fomentou a proposição do termo Sebecia (Larsson \& Sues 2007).

\section{I.I.IV. Posição filogenética de Peirosauridae, Mahajangasuchus e Stolokrosuchus}

Apesar da condição única de Peirosaurus tormini ser reconhecida desde sua descrição (Price 1955), Peirosauridae foi proposto somente por Gasparini (1982). Após um período de latência, um novo táxon foi descrito como pertencente ao grupo (Lomasuchus palpebrosus, Figura 6 A) e dois táxons de morfologia enigmática foram aproximados ao mesmo (Mahajangasuchus insignis e Stolokrosuchus lapparenti Figura 6 C). Mais recentemente, 
Uberabasuchus terrificus, Montealtosuchus arrudacamposi (Figura 6 B) e Pepesuchus deiseae foram descritos e incluídos em Peirosauridae, sendo Hamadasuchus e Gasparinisuchus reanalisado com base em espécimes mais completos e também associados ao grupo. As questões mais discutidas quanto à filogenia de Peirosauridae estão relacionadas à sua posição relativa à Trematochampsa, Araripesuchus, Sebecidae, além da possível proximidade de Mahajangasuchus e Stolokrosuchus.
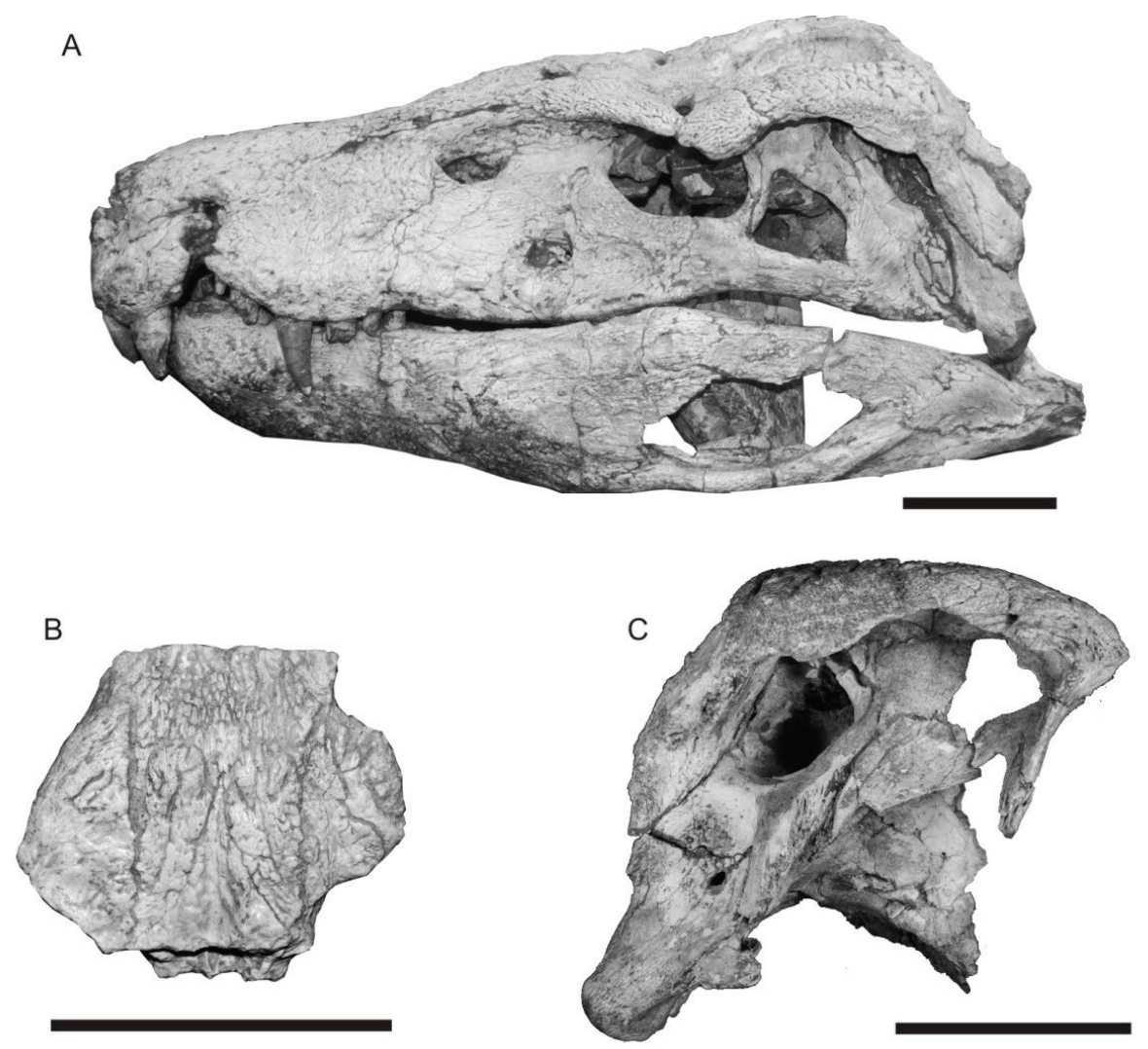

Figura 5. Exemplo de táxons atribuídos a Baurusuchidae. A- Vista lateral esquerda do crânio de Baurusuchus salgadoensis (MPMA 62-0001-02), B- Vista dorsal do teto craniano de Wargosuchus australis (MOZ-PV 6134) e C- Vista lateral direita do crânio de Baurusuchus albertoi (MZSP-PV 140). Barra de escala $5 \mathrm{~cm}$.

A proximidade de Peirosauridae (incluindo Mahajangasuchus) com Trematochampsa e Araripesuchus foi proposta repetidamente (Gasparini et al. 1991, Buckley \& Brochu 1999, Buckley et al. 2000, Tykoski et al. 2002, Turner \& Calvo 2005, Turner 2006, Lauprasert et al. 
2007, 2009). Outros estudos não reconhecem esta relação, mas consideram Peirosauridae como o grupo irmão de Neosuchia (Ortega et al. 2000, Pol \& Norell 2004ab; Pol et al. 2004; Pol \& Apesteguia 2005; Company et al. 2005, Zaher et al. 2006, Turner \& Buckley 2008, Fiorelli \& Calvo 2008, Leardi \& Pol 2009, O’Connor et al. 2010, Iori \& Carvalho 2011, Soto et al. 2011), sem, no entanto, incluir Mahajangasuchus ou Stolokrosuchus nas análises. Quando se dá a inclusão concomitante dos peirossaurídeos típicos (Peirosaurus, Lomasuchus, Uberabasuchus e Hamadasuchus), Stolokrosuchus e Mahajangasuchus nas análises, duas hipóteses são geralmente reconhecidas: (1) Stolokrosuchus e Mahajangasuchus são mais relacionados à Neosuchia, mesmo que em posições divergentes (Jouve et al. 2006, Jouve 2009, Buckley \& Brochu 2009, Andrade et al. 2011), ou (2) somente um dos táxons é aproximado a Peirosauridae. Em algumas análises, apenas Stolokrosuchus se aproxima dos peirossaurídeos típicos (Sereno \& Larsson 2009, Turner \& Sertich 2010, Holliday \& Gardner 2012), em outras somente Mahajangasuchus (Pol \& Powell 2011, Pol et al. 2012). Quanto ao posicionamento de Mahajangasuchus, a descrição de Kaprosuchus saharicus (Figura 6 D) e a sua inclusão em Mahajangasuchidae foi porposta por Sereno \& Larsson (2009) e nunca questionada desde então (Turner \& Sertich 2010, Andrade et al. 2011, Pol et al. 2012). Como mencionado anteriormente, Larsson \& Sues (2007), Young \& Andrade (2009), Sereno \& Larsson (2009), Andrade et al. (2011), Holliday \& Gardner (2012), Young et al. (2012) recuperam o clado Sebecia (Peirosauridae + Sebecidae). Ainda, alguns trabalhos propõem a aproximação de Peirosauridae à Notosuchia (Turner \& Sertich 2010, Andrade et al. 2011, Pol et al. 2012).

\section{I.I.V. Trematochampsidae}


Trematochampsidae foi proposto englobando apenas Trematochampsa taqueti (Buffetaut 1974) do Cretáceo Superior do Níger. Subsequentemente, Buffetaut \& Taquet (1979) descreveram Trematochampsa oblita, proveniente da Formação Maevarano (Maastrichtiano, Bacia de Mahajanga, Madagasgar). Estas espécies possuem dentição zifodonte e, baseado principalmente nesta característica, Buffetaut (1976, 1985, 1991, 1994) incluiu vários Crocodyliformes gonduânicos no grupo. Dentre os principais rearranjos propostos está a inclusão de Itasuchus jesuinoi na família (Buffetaut 1985) e a transferência de Caririsuchus camposi a Itasuchus (Buffetaut 1991). Recentemente, novos materiais de T. oblita foram descritos, e o táxon foi transferido para o novo gênero Miadanasuchus (Simons \& Buckley 2009). Por fim, Chiappe (1988) descreveu Amargasuchus minor, e Iori \& Garcia (2012) descreveram Barreirosuchus franciscoi que correspondem aos outros gêneros sulamericanos associados à Trematochampsidae.
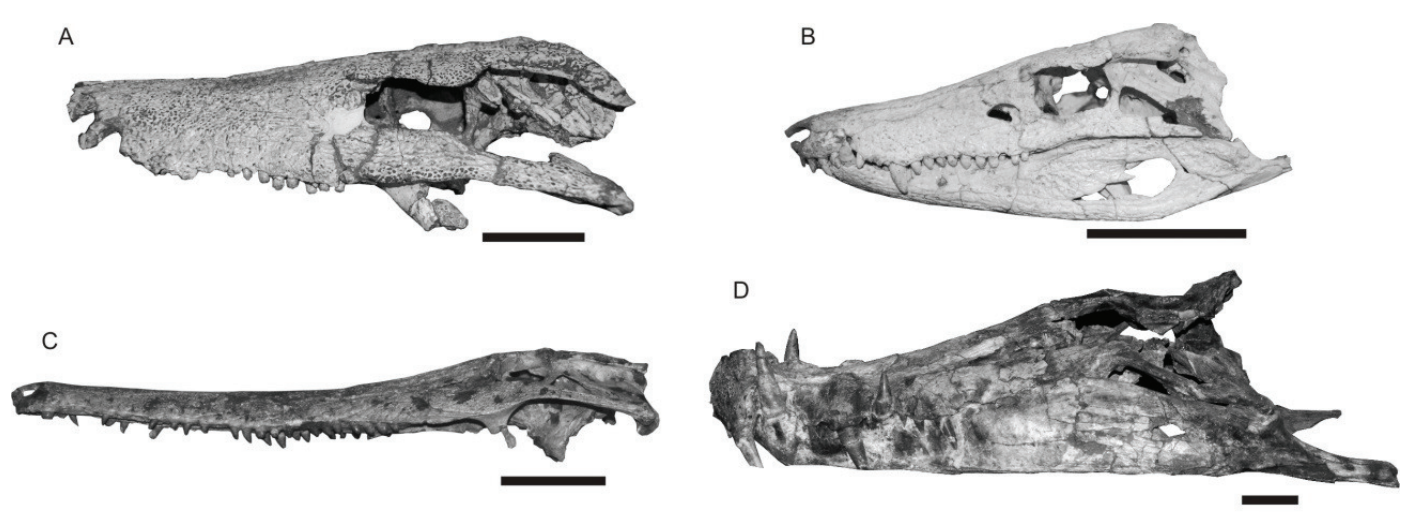

Figura 6. Exemplo de táxons atribuídos e aproximados de Peirosauridae. A- Vista lateral esquerda do crânio de Lomasuchus palpebrosus (MOZ 4084 PV), B- Vista lateral esquerda do crânio de Montealtosuchus arrudacamposi (MPMA-16-007-04), C- Vista lateral esquerda do crânio de Stolokrosuchus lapparenti (MNN GDF 600) e D- Vista lateral esquerda do crânio de Kaprosuchus saharicus (MNN-IGU 12). Barra de escala $5 \mathrm{~cm}$.

Trematochampsidae apresenta uma sistemática controversa e a maioria dos táxons (incluindo T. taqueti) é baseada em materiais extremamente fragmentários. Adicionalmente, a 
zifodontia é atualmente reconhecida em um grande número de Crocodyliformes não filogeneticamente relacionados (vide Langston 1956, Berg 1966, Hecht \& Archer 1977, Turner \& Calvo 2005, Turner 2006). No que tange às relações filogenéticas, a existência de um grupo monofilético que circunscreva os táxons tentativamente incluídos em Trematochampsidae é questionável (Gasparini et al. 1991, Ortega et al. 1996, Buckley \& Brochu 1999, Larsson \& Sues 2007). No entanto, a reavaliação recente de Trematochampsa taqueti e Miadanasuchus oblita (Sertich \& O'Connor 2010, Sertich 2011), sugere a validade dessas espécies e família. Porém, pelo parco número de caracteres codificáveis em seus representantes, poucas análises filogenéticas incluem possíveis trematochampsídeos, e quando isso acontece, estes ou apresentam-se associados à Peirosauridae (Buckley \& Brochu 1999, Buckley et al., 2000, Tykoski et al. 2002, Turner \& Calvo 2005, Turner 2006, Lauprasert et al. 2007, 2009), ou como ramo basal de Neosuchia (Ortega et al. 2000, Company et al. 2005). 


\section{OBJETIVOS}

O objetivo geral do projeto de doutorado, a que se refere esta tese, permeava dois pontos principais: o estudo dos espécimes LPRP/USP 0017-0019, e a revisão filogenética de Meoseucrocodylia. O estudo dos espécimes foi elaborado juntamente com a revisão filogenética de Baurusuchidae, e serviram de base para a definição de um novo táxon, Pissarrachampsa sera. A publicação derivada deste estudo encontra-se anexo ao documento aqui apresentado. Posto isso, o corpo da tese foi estruturado como uma ampla revisão de Mesoeucrocodylia de modo a não tratar os pontos já discutidos no artigo publicado.

Portanto, o objetivo maior do trabalho aqui apresentado é elaborar uma ampla revisão filogenética a partir de representantes dos principais grupos de Mesoeucrocodylia que permita testar a monofilia e inter-relações de grupos como Thalattosuchia, Notosuchia, Sebecosuchia, Sebecia, Peirosauridae, e Trematochampsidae. 


\section{MATERIAIS E MÉTODOS}

Três principais frentes de trabalho foram investigadas para elaboração de uma nova proposta filogenética para os Mesoeucrocodylia. Primeiramente, os táxons terminais da análise foram selecionados. Outro ponto importante é a seleção dos caracteres a serem utilizados na análise, tanto aqueles anteriormente utilizados nas análises de Mesoeucrocodylia, como novas variações reconhecidas. Finalmente, definiu-se a metodologia empregada nas buscas computacionais a ser utilizada na análise.

\section{III.I. Delimitação dos táxons terminais}

O primeiro passo para escolher os táxons terminais foi a limitação do universo de táxons potenciais para a análise com a delimitação concomitante do grupo interno e externo (Nixon \& Carpenter 1993). O ponto inicial foi o reconhecimento de Pissarrachampsa sera como um Baurusuchidae (Montefeltro et al. 2011), que por sua vez, está envolvido em questões controversas da filogenia de Mesoeucrocodylia. Deste modo, Mesoeucrocodylia foi estabelecido como grupo interno da análise, como na concebido por Benton \& Clark (1988) e Clark (1994) e corroborado consistentemente nas análises filogenéticas, mesmo com base de dados divergentes (ex.: Wu et al. 1994ab 1997, Buckley \& Brochu 1999, Buckley et al. 2000, Sereno et al. 2001, 2003, Pol et al. 2004, 2009, 2012, Turner 2006, Larsson \& Sues 2007, Fiorelli \& Calvo 2008, Sereno \& Larsson 2009, Pol \& Gasparini 2009, Jouve 2009, Young \& Andrade 2009, Turner \& Sertich 2010, Clark 2011, Young et al. 2012). O grupo externo foi delimitado com base em análises prévias que apresentam Crocodyliformes e Crocodylomorpha como clados subsequentemente mais abrangentes que circunscrevem Mesoeucrocodylia (Benton \& Clark 1988, Wu \& Chatterjee 1993, Clark 1994, Clark et al. 2000, 2002, 2004, Sues et al. 2003, Nesbitt 2011). 
A partir destes limites estabelecidos, os táxons terminais a serem incluídos na análise de parcimônia foram escolhidos visando maximizar o número de táxons incluídos. Esta seleção está imersa em um compromisso entre os objetivos do presente trabalho, os táxons descritos para o universo selecionado, os táxons empregados em análises prévias e a disponibilidade de materiais observados em primeira mão nas coleções científicas visitadas.

Foram selecionados 122 táxons terminais para a análise de parcimônia (para a lista completa dos táxons ver Apêndice I). Dentre os táxons selecionados, 13 são pertencentes ao grupo externo (3 Crocodylomorpha não Crocodyliformes e 10 Crocodyliformes não Mesoeucrocodylia). No grupo interno, foi dado maior enfoque para os Mesoeucrocodylia envolvidos nas questões delimitadas na Introdução. Dos 109 táxons do grupo interno, 78 são representantes de Thalattosuchia (13 táxons), "Notosuchia” (29 táxons), Sebecosuchia (11 Baurusuchidae e 10 Sebecidae), Peirosauridae (8 táxons) e Trematochampsidae (4 táxons). Finalmente, 31 dos táxons terminais compreendem a porção mais derivada em direção à Neosuchia, Eusuchia e Crocodylia. Crocodylia, por sua vez, é representados por 3 táxons terminais de espécies viventes.

Dos táxons terminais selecionados, 117 foram incluídos em nível específico, mas dois táxons do grupo interno (Theriosuchus e Crocodylus) e três do grupo externo (Hsisosuchus, Sichuanosuchus e Shantungosuchus) englobam mais que uma espécie de um mesmo gênero. Com base na análise pessoal de espécimes em coleções e por representarem entidades taxonômicas únicas, 7 táxons terminais foram incluídos, apesar de não terem sido formalmente descritas.

\section{III.II. Caracteres utilizados na análise}

\section{III.II.I Compilação de dados e montagem da lista final de caracteres}


Como mencionado anteriormente, a produção científica dos últimos 20 anos envolvendo os Crocodyliformes fósseis é extensa. Essa grande quantidade de informações também tem reflexos nos caracteres utilizados nas análises filogenéticas. Nos trabalhos pioneiros de Clark (1994) e Wu et al. (1997), 101 e 109 caracteres foram respectivamente utilizados nas análises de parcimônia de Crocodyliformes. Publicações mais recentes como Andrade et al. (2011) e Pol et al. (2012) utilizam 486 e 347 caracteres respectivamente. Apesar disso, a maioria das análises representa expansões óbvias ou combinações de análises prévias, em especial, as de Clark (1994) e Ortega et al. (2000) (Jouve et al. 2006, Bronzati et al. 2012). Assim, optou-se por basear esta revisão em análises amplas e recentes que apresentassem certo nível de independências entre sí.

Com base nesses critérios, as análises inicialmente selecionadas foram Sereno \& Larsson (2009), Andrade et al. (2011) e Pol \& Powell (2011). Todavia, outras duas publicações amplas foram posteriormente adicionadas à lista. Turner \& Sertich (2010) e Pol et al. (2012), mesmo que estas últimas, juntamente com Pol \& Powell (2011), representassem expansões da base de dados encontrada em Pol et al. (2009). As análises de Turner \& Sertich (2010) e Pol et al. (2012) foram também incluídas, pois apresentam um esquema de amostragem de táxons que se coaduna aos objetivos da revisão filogenética proposta. Adicionalmente, Pol et al. (2012) também introduz uma grande quantidade de novos caracteres pós-cranianos.

Os caracteres incluídos nestas cinco bases de dados representam a maior parte dos caracteres já propostos para os Mesoeucrocodylia basais e cobrem competentemente a amplitude taxonômica selecionada para esta análise. Porém, caracteres de outras publicações foram também incluídos a fim de obter melhor resolução e suporte para áreas específicas da amostragem taxonômica. Estas análises são citadas quando representam a fonte original dos caracteres utilizados, e também foram utilizadas como auxiliar para a redefinição de 
caracteres, ou estados de caracteres, presentes nas análises principais. A lista completa de caracteres se encontra no Apêndice II, e as análises adicionais utilizadas são: Buscallioni \& Sanz (1988), Norell (1988), Buscalioni et al. (1992), Wu \& Chatterjee (1993), Gasparini et al. (1993), Ortega et al. (1996), Wu \& Sues (1996), Gomani (1997), Brochu (1999), Pol (1999), Larsson \& Gado (2000), Buckley et al. (2000), Clark \& Sues (2002), Martinelli (2003), Turner (2004), Jouve (2004, 2009), Pol \& Norell (2004ab), Pol et al. (2004), Pol \& Apesteguia (2005), Jouve et al. (2005), Turner (2006), Zaher et al. (2006), Gasparini et al. (2006), Larsson \& Sues (2007), Osi et al. (2007, 2008), Turner \& Buckley (2008), Andrade \& Bertini (2008a), Wilkinson et al. (2008), Jouve (2009), Pol et al. (2009), Young \& Andrade (2009), Novas et al. (2009), Young et al. (2011b), Fortier et al. (2011), Buscalioni et al. (2011), Riff \& Kellner (2011), Young et al. (2012).

Mesmo esta revisão tendo sido majoritariamente baseada em poucas análises prévias, a compilação crua de suas matrizes de dados levou ao acúmulo de caracteres redundantes (ver Brazeau 2011). A redundância entre caracteres foi minimizada reunindo e redefinindo os caracteres que tratavam da mesma variação morfológica. Para isso, os caracteres redundantes foram comparados e a definição usada obedeceu a critérios de maior consistência em termos de homologia, independência de observações, objetividade, e clareza na descrição. Um processo similar foi utilizado para casos de "ausências repetidas" (repeated absences, Brazeau 2011). Nesses casos, o estado ausente foi mantido em somente um caráter, enquanto autapomorfias e estados não informativos (sensu Brazeau 2011) foram excluídos da análise.

Um procedimento extra foi utilizado em caso de caracteres de estados múltiplos. Em caso de interpretação de homologias hierárquicas (sensu Lipscomb 1992, Strong \& Lipscomb 1999) os caracteres foram submetidos à codificação contingencial (sensu Forey \& Kitching 2000, Sereno 2007, Brazeau 2011). Todavia, em alguns casos, caracteres de estados múltiplos foram mantidos quando interpretados como valores equivalentes (Brazeau 2011), sendo 
mantidos como não aditivos. Adicionalmente, houve a proposição de novos caracteres, bem como de estados de caracteres abarcando novas variações e/ou reinterpretações sobre homologias já propostas. A lista final de caracteres é composta por 494 caracteres, sendo 17 caracteres novos.

\section{III.II.II Codificação dos táxons}

Com as listas de táxons e caracteres prontas, o preenchimento da matriz se deu com base em três tipos de fontes: observação direta dos espécimes, material fotográfico, e literatura, com base em descrições e codificação em matrizes prévias. A fonte de informação utilizada para cada táxon está explícita no Apêndice I, e as codificações compõem matriz resultante (Apêndice III). Para táxons terminais analisados pessoalmente, a informação disponível na literatura só foi utilizada em caso de ambiguidades. Em caso de táxons com acesso a material fotográfico suplementar, a literatura só foi usada quando as imagens eram insuficientes. Para os demais táxons, recorreu-se integralmente a literatura. Deste modo, 79\% dos táxons foram codificados com base em observação pessoal, $10 \%$ baseados em material fotográfico suplementar, e $11 \%$ baseado em descrições e em codificações encontradas em trabalhos prévios.

\section{III.III. Parâmetros da análise filogenética}

A matriz táxon-caráter (122 x 494, apêndice III) foi construída utilizando o software Mesquite 2.75 (Maddison \& Maddison 2011) e as análises de parcimônia foram feitas com o software TNT 1.1 (Goloboff et al. 2008). As buscas heurísticas foram conduzidas utilizando 5000 réplicas com adição randômica de táxons (randon seed 0), o algoritmo tree bisection e 
reconection (TBR) para o branch swapping e hold de 20. Os índices de otimização (consistência e retenção), e os cálculos de árvore de consenso, foram estabelecidos por meio de rotinas desenvolvidas pelos programas utilizados. As proporções de bootstrap (GC e frequências absolutas, Felsenstein 1985, Goloboff et al. 2008) e jacknife (GC, Farris et al. 1996, Goloboff et al. 2008), com 1000 pseudoréplicas (Holmes 2003), bem como os índice de decaimento de Bremer (1994), foram calculados também utilizando o TNT. As análises exploratórias citadas na discussão foram feitas utilizando constrains positivos e negativos (comandos force + e force -) do TNT, sob os mesmos parâmetros da análise total.

\section{RESULTADOS}

A análise de parcimônia resultou em 3575 árvores igualmente parcimoniosas com 2347 passos e com índices $\mathrm{CI}=0.24, \mathrm{RI}=0.67$. $\mathrm{O}$ consenso estrito das árvores mais parcimoniosas está representado na Figura 7. Os índices de suporte de bootstrap, jacknife e suporte de Bremer estão no apêndice IV, juntamente com a lista de sinapomorfias dos clados recuperados no consenso estrito.

\section{DISCUSSÃO}

Um dos problemas gerais relacionados à irradiação basal dos Mesoeucrocodylia é a falta de sobreposição na amostragem taxonômica dentre as múltiplas hipóteses filogenéticas encontradas na literatura, o que dificulta uma comparação tangível dos diferentes resultados (Pol \& Larsson 2011, Bronzati et al. 2012). A vasta amostragem de táxons de Mesoeucrocodylia basais utilizada na presente análise tenta contornar este problema e permite 
discutir a posição filogenética tanto dos principais grupos de Mesoeucrocodylia quanto de táxons específicos em um contexto mais amplo.

Isso é particularmente desejável para averiguar a posição filogenética de táxons incluídos em poucas análises prévias (ex.: Khoratosuchus, Stratiotosuchus, Sebecus querejazus, Itasuchus, Montealtosuchus, Trematochampsa, Morrinhosuchus), táxons descritos previamente, mas pela primeira vez incluídos em uma análise filogenética (ex.: Campinasuchus, Barreirosuchus, Pepesuchus, Doratodon ibericus, Labidiosuchus, Mariliasuchus robustus), e ainda não formalmente descritos (ex.: Araripesuchus $c f$. Niger, Metriorhynchidae Áustria, Cricosaurus Colômbia, Dyrosauridae Bolívia). Adicionalmente, Araripesuchus rattoides e Laganosuchus maghrebensis, descritos inicialmente com base em materiais fragmentários, tiveram sua posição filogenética melhor avaliada com base em espécimes mais completos ainda não descritos.

Um efeito inerente à ampla amostragem taxonômica da presente análise é a inclusão de uma série de táxons fragmentários (ex.: Aegisuchus, Doratodon ibericus, Cynodontosuchus, Peirosaurus, Iberosuchus) e consequentemente uma grande quantidade de missing data na análise. Adicionalmente, a revisão dos caracteres, em especial os caracteres pós-cranianos, também resultou na inclusão de grande quantidade de missing data. Missing data é uma reconhecida fonte de instabilidade em análises filogenéticas (Platnick et al. 1991, Maddison 1993, Wilkinson \& Benton 1995, Kearney \& Clark 2003, Pol \& Escapa 2009), sendo mais comum em, porém não restrita à, análises envolvendo táxons fósseis (Gauthier et al. 1988, Wilkinson 1995, 2003, Prevosti \& Chemisquy 2009). A árvore de consenso estrito encontra-se relativamente bem resolvida (Figura 7) sendo encontradas apenas 15 politomias. 


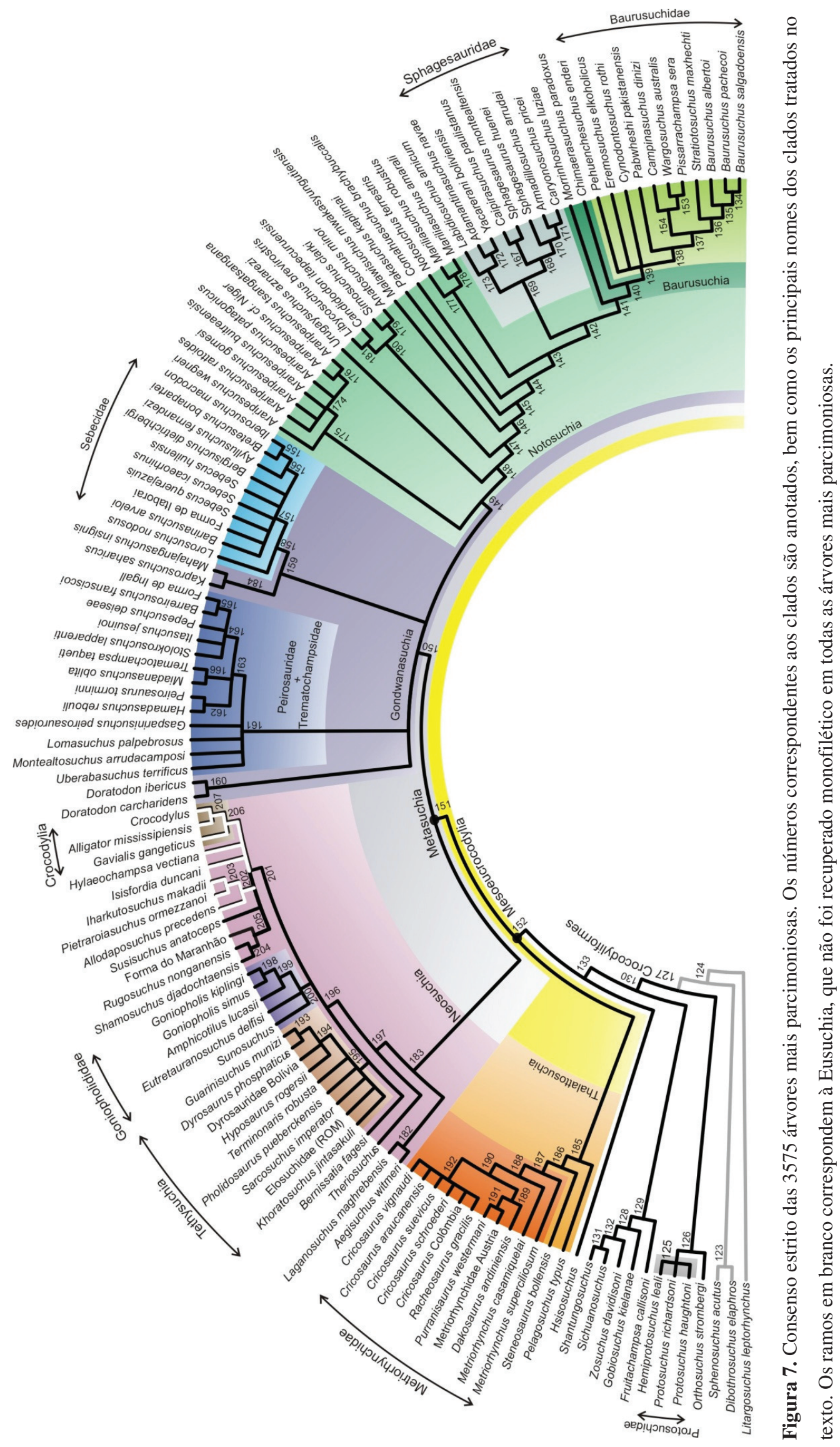


Assim, os missing data aparentemente não levaram à geração de múltiplas hipóteses filogenéticas igualmente mais parcimoniosas, como recorrentemente se observa (Nixon \& Wheeler 1992, Kearney \& Clark 2003, Wilkinson 2003). Porém, os baixos valores das medidas de suporte calculadas (Apêndice IV), podem ter relação com os missing data (Wenzel \& Sidal 1999, Norell \& Wheeler 2003, Wilkinson 2003, Prevosti \& Chemisquy 2009). A exclusão de informações, mesmo que conflitantes, é de difícil justificativa no contexto cladístico (Kearney \& Clark 2003, Wiens 2005), tanto em relação a táxons (Wilkinson \& Benton 1995, Norell \& Wheeler 2003), quanto caracteres (Kearney 2002, Wiens 2003, Prevosti \& Chemisquy 2009). Assim, os resultados obtidos serão discutidos apesar das ambiguidades internas na base de dados, e da falta de suporte estatístico em pontos específicos da topologia, que serão resaltados quando pertinentes.

\section{V.I. Topologia do grupo externo}

\section{V.I.I Crocodylomorpha não Crocodyliformes}

A metodologia empregada na definição dos grupos interno e externo segue, em termos gerais, a metodologia empregada por Nixon \& Carpenter (1993). O único clado cuja monofilia foi forçada a priori é o agrupamento de todos os táxons a parte de Litargosuchus, considerado o primary outgroup da análise (Barriel \& Tassy 1998). Caracteres que dizem respeito a variações do grupo externo foram utilizados na análise, bem como novos caracteres e estados de caracteres propostos para os subgrupos do grupo externo (ex.: caráter 488[2]).

Uma deficiência da presente análise encontra-se na amostragem de caracteres referentes aos Crocodylomorpha não Crocodyliformes (Dibothrosuchus, Litargosuchus e Sphenosuchus) e caracteres apomórficos de Crocodyliformes. Não foi incorporado um vasto número de caracteres presentes em filogenias de cunho mais abrangente, em que apomorfias 
de Crocodyliformes estão melhor discutidas (ex.: Clark et al. 2000, 2004, Clark \& Sues 2002, Sues et al. 2003, Nesbitt 2011). No entanto, o clado Crocodyliformes encontra-se bem suportado. O posicionamento de Litargosuchus como primary outgroup foi assumido baseado em Clark \& Sues (2002) e Clark et al. (2004), mesmo que Nesbitt et al. (2011) apresente Litargosuchus como mais derivado na direção dos Crocodyliformes. Análises exploratórias intercambiando o primary outgroup entre os outros dois táxons supracitados resultam em árvores mais parcimoniosa com o mesmo número de passos e com a mesma topologia do consenso estrito da Figura 7. Adicionalmente, a aproximação de Dibothrosuchus e Sphenosuchus é concordante com Clark et al. (2000), Clark \& Sues (2002) e Sues et al. (2003), porém em desacordo com Clark et al. (2004) e Nesbit (2011) em que estes táxons estão arranjados como grupos sucessivamente mais próximos de Crocodyliformes.

\section{V.I.II Crocodyliformes não Mesoeucrocodylia}

Os Crocodyliformes não Mesoeucrocodylia, majoritariamente representados pelos táxons tradicionalmente atribuídos à "Protosuchia" são formas enigmáticas morfologicamente, estratigraficamente, biogeograficamente e temporalmente (Ósmolska et al. 1997, Pol \& Norell 2004ab, Pol et al. 2004, Fiorelli \& Calvo 2007, Clark 2011), apresentando relações filogenéticas muito variáveis nas diferentes análises em que foram incluídos (ver Wu et al. 1994ab, 1997, Fiorelli \& Calvo 2007, Pol \& Norell 2004ab, Andrade et al. 2011, Pol et al. 2012). A presente análise tem o foco em a Mesoeucrocodylia assim, uma série de formas externas ao clado foi deliberadamente excluída, em especial, a diversidade dos Shartegosuchidae asiáticos, Zaarasuchus, o protosuquídeo de dentes multicuspidados Edentosuchus e a forma norte americana afim (Young 1973, Clark 1986, 2011, Sues et al. 1994, Pol et al. 2004). Adicionalmente, os táxons terminais Sichuanosuchus, 
Shantungosuchus e Hsisosuchus representam táxons supra específicos, estando negligenciada a diversidade de táxons circunscrita nestes gêneros.

A aproximação de Ortosuchus à Protosuchidae, formando o clado mais basal de Crocodyliformes (clado 126) é concordante com uma série de análises prévias gerais de Crocodyliformes, bem como trabalhos focados em "Protosuchia" (Pol \& Norell 2004a, Pol et al. 2004, Clark 2011). O clado 129, formado por Fruitachampsa, do Jurássico da América do Norte, e táxons do Cretáceo da Ásia, incluindo Gobiosuchus, nunca foi recuperado em análises anteriores. Porém, o mesmo clado, sem Gobiosuchus, foi recuperado por Fiorelli \& Calvo (2007). Já a posição de Hsisosuchus, do Jurássico da China, como grupo irmão de Mesoeucrocodylia é consistentemente encontrada com, ou sem, a inclusão de táxons de Shartegosuchidae na análise (Wu et al. 1994ab, Pol \& Norell 2004ab, Fiorelli \& Calvo 2007, Pol \& Gasparini 2009, Sereno \& Larsson 2009, Clark 2011, Riff \& Kellner 2011, Pol \& Powell 2011, Andrade et al. 2011).

A presente análise não provê melhor entendimento sobre aspectos macroevolutivos desta parte obscura da evolução dos Crocodyliformes. O domínio de formas asiáticas, mas com registros contundentes em outros continentes, implica em padrão biogeográfico complexo, em que podem estar envolvidos diversos eventos vicariantes e dispersivos durante

o Triássico e Jurássico. Um evento dispersivo através da Europa no Jurássico foi proposto para os Shartegosuchidae (Clark 2011). Mas, outros eventos precisam ser investigados para explicar, por exemplo, a presença de Neuquensuchus no Cretáceo da América do Sul, ou a distribuição do Gênero Protosuchus na América do Norte e África do Sul.

\section{V.II. Topologia do grupo interno}

\section{V.II.I. Mesoeucrocodylia, Metasuchia e o posicionamento de Thalattosuchia}


Mesoeucrocodylia e Metasuchia são dois nomes aplicados inicialmente por Benton \& Clark (1988) para designar grandes clados de Crocodyliformes mais derivados que os tradicionais "Protosuchia". Mesoeucrocodylia foi adaptado de Whetstone \& Whybrown (1983) no contexto da sistemática filogenética, e apesar de Benton \& Clark (1988) não apresentarem uma definição formal, este é representado por Thalattosuchia + Metasuchia. Metasuchia, por sua vez, também proposto naquele trabalho, foi definido como os Mesoeucrocodylia não Thalattosuchia. Portanto, suas delimitações estão intrinsecamente conectadas e a aplicação precisa destes termos guarda relação com a posição filogenética de Thalattosuchia. Quando Thalattosuchia encontra-se afim à Neosuchia, os termos são sinônimos (Benton \& Clark 1988). Neste contexto ainda, os resultados de Benton \& Clark (1988) sugerem Fruitachampsa (denominado Fruita Form, naquele trabalho) como o Metasuchia mais basal.

A incorporação posterior de outros táxons no contexto filogenético resultou em reinterpretações sobre a filogenia de Crocodyliformes e obscureceu a aplicação precisa destes dois termos, bem como suas correspondências topológicas e sinapomorfias. Trabalhos posteriores utilizam estes termos, em especial Mesoeucrocodylia, com abrangências variáveis. Em uma comparação simples entre análises com topologias similares nesta porção do cladograma, Turner \& Sertich (2010) incluem Fruitachampsa em Mesoeucrocodylia, Pol et al. (2012), aceitam o clado um pouco mais restrito, excluindo Fruitachampsa, enquanto Andrade et al. (2011) incluem Gobiosuchus e Hsisosuchus como componentes basais de Mesoeucrocodylia (Fruitachampsa não foi incluído). Na presente análise, Fruitachampsa foi recuperado como pertencente ao clado 129 juntamente com Gobiosuchus, que foi claramente excluído de Mesoeucrocodylia por Benton \& Clark (1988). Na ausência de uma definição formal para o clado Mesoeucrocodylia, e com o intuito de manter sua correspondência topológica mais próxima à concepção original, o nome é assinalado ao clado 152, composto 
por Thalattosuchia e seu grupo irmão (clado 151). De maneira similar, devido à posição basal de Thalattosuchia, o termo Metasuchia é aplicável ao clado 151.

Visto que tanto Thalattosuchia, quanto os Crocodyliformes não Mesoeucrocodylia apresentam posições variáveis nas múltiplas filogenias. As sinapomorfias correspondentes aos clados Meoseucrocodylia e Metasuchia (quando aplicável) também são lábeis. Para uma comparação adequada entre as possíveis sinapomorfias de Mesoeucrocodylia, foi feita a equivalência deste clado, na presente análise, ao clado Metasuchia de Andrade et al. (2011). A única sinapomorfia reconhecida para Mesoeucrocodylia tanto em Benton \& Clark (1988), Sereno \& Larsson (2009), Pol \& Powell (2011), Andrade et al. (2011), Pol et al. (2012) quanto na presente análise é a presença de um palato secundário maxilar completo anterior ao palatino (caráter 203[1] Figura 8). Esta morfologia do palato secundário foi inclusive reconhecida por Huxley (1875) para definir "Mesosuchia".

Dada a posição basal de Thalattosuchia, algumas sinapomorfias apontadas para Mesoeucrocodylia nos trabalhos prévios não são reconhecidas como tal, algumas das quais se tornam sinapomórficas de Metasuchia (caracteres 83[1], 170[2] e 191[1]). Ainda, um novo caráter relacionado à parede posterior do forâmen esutaquiano medial (caráter 489, Figura 9) foi recuperando como sinapomorfia para Metasuchia, estando ausente em táxons mais basais, incluindo Thalattosuchia.

Adicionalmente, uma análise exploratória, forçando a monofilia de Thalattosuchia + Tethysuchia foi feita. As árvores mais parcimoniosas resultantes desta análise são sete passos mais longos, apresentando cinco potenciais sinapomofias não ambíguas para o clado. Dentre estes, a presença de um rostro tubular e dentes homodontes são caracteres intimamente relacionados à animais aquáticos piscívoros (Clark 1994, Busbey 1995, Pierce et al. 2008, 2009, Jouve 2009, Young et al. 2010). Ainda, a ausência de fenestras no quadrado pode 
também estar relacionada ao hábito aquático destes táxons (Montefeltro \& Larsson 2011, 2012). Assim, baseado na presente base de dados, um grupo monofilético envolvendo os táxons longirostrinos seria suportado grandemente por caracteres eco-funcionais e deve ser visto com cautela (Benton \& Clark 1988, Clark 1994, Jouve 2009, ver Pol \& Gasprini 2009 para contraponto).

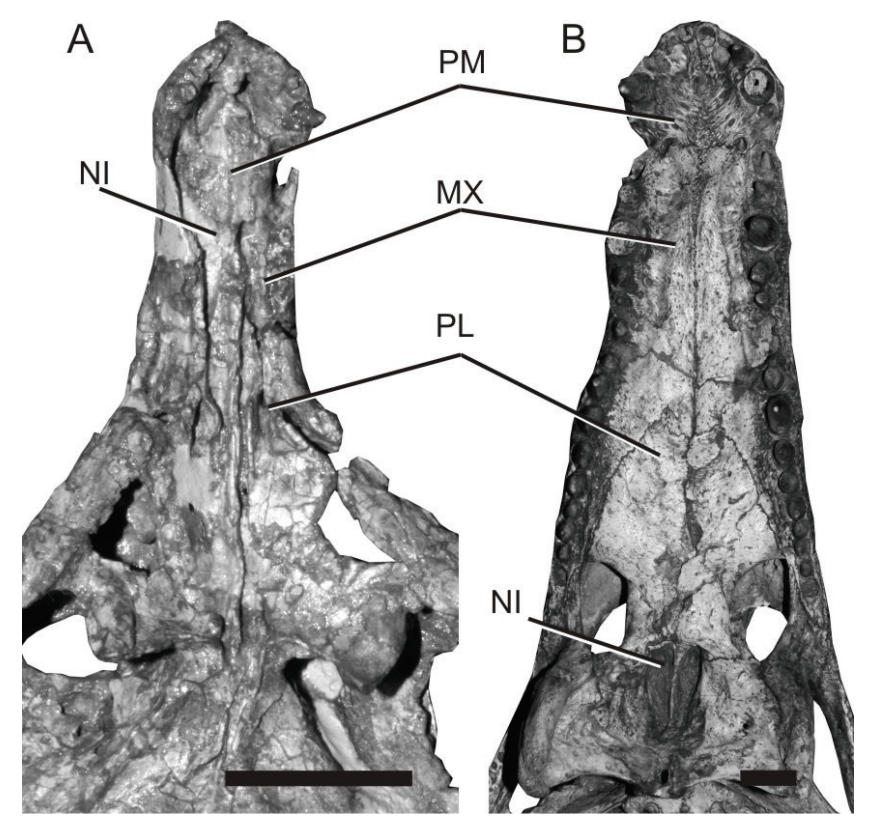

Figura 8. Caráter 203. A- Vista ventral da região anterior do crânio de Orthosuchus strombergi (SAM PK K 4639) exemplificando o ramo posterior das maxilas, que não se contatam anterior ao palatino; B- Vista ventral da região anterior do crânio de Hamadasuchus rebouli (ROM 52620) exemplificando o ramo posterior das maxilas, que se contatam anterior ao palatino. Legenda: MX, maxila; NI, narina interna; PL, palatino; PM, pré-maxila. Barra de escala $2 \mathrm{~cm}$.

Outro aspecto com influência direta sobre o posicionamento filogenético de Thalattosuchia entre os crocodiliformes é a morfologia peculiar do complexo antero-orbital (fenestras e fossa antero-orbital) do grupo. Esta condição única dificulta o estabelecimento de relação de homologias entre as partes do complexo antero-orbital dos Thalattosuchia com as respectivas estruturas nos demais Crocodyliformes e outros Archosauria (Witmer 1997, Jouve 2009). Estudos morfológicos desta região anatômica tem demonstrado consistentemente que o 
complexo antero-orbital de Metriorhynchidae estaria relacionado à excreção de sal, ao invés de um divertículo pneumático como nos demais Archosauria (Fernandez \& Gasparini 2000, 2008, Gandole et al. 2006, Fernandez \& Herrera 2009). Sob essa perspectiva, este complexo, em Metriorhynchidae, representaria uma estrutura neomórfica. Leardi et al. (2012) testaram tais hipóteses com base em estudos de homologia dinâmica e sugerem que a fenestra anteroorbital de Metriorhynchidae não seria homóloga à fenestra antero-orbital dos demais Thalattosuchia e Archosauria. Para investigar as possíveis influências deste fator na presente base de dados, uma análise exploratória foi feita recodificando para não aplicáveis os caracteres relacionados à fenestra antero-orbital nos táxons de Metriorhynchidae (caracteres $12,13,14,59)$. Os resultados apresentam árvore de consenso com a mesma estrutura da análise original, com um passo mais a menos e não influenciando severamente os resultados obtidos.
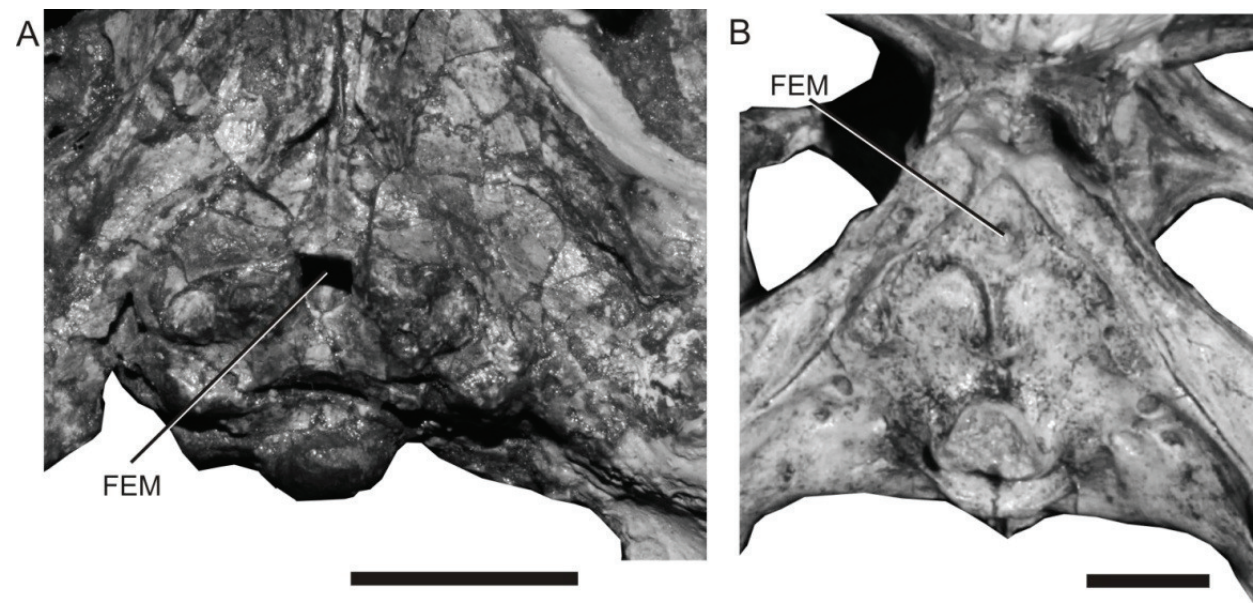

Figura 9. Caráter 489. A- Vista ventral da região posterior do crânio de Orthosuchus strombergi (SAM PK K 4639) exemplificando o forâmen esutaquiano medial sem parede posterior; B- Vista ventral da região posterior do crânio de Araripesuchus wegneri (MNN GAD19) exemplificando o forâmen esutaquiano medial com parede posterior. Legenda: FEM, forâmen eustaquiano medial. Barra de escala $1 \mathrm{~cm}$. 


\section{V.II.II. Inter-relações de Thalattosuchia e a posição do Cricosaurus da Colômbia}

Thalattosuchia (clado 185) é um dos grupos monofiléticos melhor estabelecidos dentre os Crocodyliformes, sendo frequentemente o clado com maior suporte estatístico nas análises filogenéticas (ex.: Sereno \& Larsson 2009, Jouve 2009, Pol et al. 2012), bem como da presente análise. Entretanto, a filogenia de seus subgrupos é, em geral, negligenciada, e somente recentemente análises de parcimônia com ampla amostragem taxonômica foram proferidas (Mueller-Towe 2005, 2006, Gasparini et al. 2006, Jouve 2009, Pol \& Gasparini 2009, Young \& Andrade 2009, Young et al. 2010, 2011ab, 2012). As inter-relações de seus subgrupos variam bastante nas análises prévias, com os Teleosauridae como um arranjo parafilético em relação à Metriorhynchidae (ex.: Jouve 2009, Turner \& Sertich 2010, Andrade et al. 2011, Young et al. 2012, Pol et al. 2012) ou como um clado irmão deste (Mueller-Towe 2005, 2006, Gasparini et al. 2006, Sereno \& Larsson 2009, Young \& Andrade 2009, Pol \& Powell 2011). Na presente análise, Pelagosaurus foi recuperado como o táxon mais basal, seguido de Steneosaurus como grupo irmão de Metriorhynchidae (clado 187). Metriorhynchidae, também é um grupo estatisticamente bem suportado, sendo caracterizado por uma série de sinapomorfias, não somente relacionadas ao hábito pelágico. O arranjo interno do clado não suporta a monofilia de Geosaurinae e Metriorhynchinae (sensu Young \& Andrade 2009), mas Metriorhynchus superciliosum e Metriorhynchus casamiquelai se posicionam como grupos irmãos sucessivos do clado 190. Dentre as relações encontradas no clado 190, destaca-se o agrupamento de Racheosaurus gracilis, dos táxons associados ao Gênero Cricosaurus (sensu Young \& Andrade 2009), e de um táxon não descrito da Colômbia associado à Cricosaurus por Larsson et al. (2011). Analisando as árvores mais parcimoniosas, a possível não monofilia de Cricosaurus é causada principalmente pela posição variável do táxon colombiano, que pode formar um clado com Racheosaurus gracilis ou oscilar como grupo irmão de certos Cricosaurus. Três características foram detectadas 
como relacionadas à posição flutuante do táxon da Colômbia. O ângulo entre as margens anterior e medial da fenestrae temporal superior externa formando aproximadamente $45^{\circ}$ (caráter 99) sugere a aproximação da forma colombiana aos Cricosaurus, no entanto, o processo posteromedial do squamosal orientado transversalmente (caráter 112) sugere uma aproximação à Racheosaurus. Adicionalmente a ausência da curvatura do arco temporal (caráter 125) na forma Colombiana sugere o agrupamento dos Cricosaurus sem a inclusão desta forma.

\section{V.II.III. Dicotomia Neosuchia/Gondwanasuchia}

Neosuchia foi definido por Benton \& Clark (1988) para representar o clado circunscrevendo os táxons mais derivados dos tradicionais "Mesosuchia" (Atoposauridae, Goniopholididae, Pholidosauridae, Dyrosauridae, Bernissartia e Shamosuchus) e Eusuchia. A existência deste clado tem sido corroborada virtualmente em todas as análises abrangentes de Crocodyliformes, mantendo essencialmente a correspondência topológica da concepção original (salvaguardando a possível afinidade de Thalattosuchia ao clado). Adicionalmente, Larsson \& Sues (2007) definem Neoscuhia como todos os táxons mais próximos de Crocodylus niloticus que à Sebecus icaeorhinus. Na presente análise, a definição de Larsson \& Sues (2007) é aplicável, e Neosuchia foi associado ao clado 183, abrangendo também os táxons Laganosuchus e Aegisuchus. Na concepção original de Neosuchia, Stomatosuchidae, clado que engloba Laganosuchus, não foi contemplado, porém, sua inclusão está implícita, pois Stomatosuchus é incluído na definição de Eusuchia de Benton \& Clark (1988).

Apesar de Neosuchia ser consistentemente recuperado, uma gama de possíveis grupos imediatamente externos a este já foi proposta, destacando-se Araripesuchus, Stolokrosuchus, Mahajangasuchus, Peirosauridae e Trematochampsidae (ex.: Ortega et al. 2000, Turner 2006, 
Larsson \& Sues 2007, Turner \& Buckley 2008, Pol \& Gasparini 2009, Turner \& Sertich 2010). Na análise apresentada, todos estes possíveis táxons outrora aproximados à Neosuchia estão agrupados em um amplo grupo irmão de Neosuchia juntamente com os demais "Notosuchia", Doratodon, Baurusuchidae e Sebecidae. Este clado inclui todos os táxons inseridos na confusa definição de Gondwanasuchia e de seus subgrupos de Carvalho et al. (2004). Porém, devido à topologia da presente análise, o nome Gondwanasuchia representará o clado 150.

Apesar da dicotomia Neosuchia/Gondwanasuchia ser contrastante com a maioria das análises prévias de Crocodyliformes (ver Clark 1994, Ortega et al. 2000, Sereno et al. 2001, 2003, Pol \& Norell 2004ab, Turner 2006, Turner \& Buckley 2008, Sereno \& Larsson 2009, Pol \& Gasparini 2009, Lauprasert et al. 2009, Pol \& Powell 2011), análises mais recentes tem recuperado estas relações, com variações menores nos componentes dos clados, mesmo sem a aplicação do nome ao clado (Turner \& Sertich 2010, Andrade et al. 2011, Pol et al. 2012).

Devido à presença de Stomatosuchidae, representado por dois táxons relativamente incompletos, na base de Neosuchia, uma série de potenciais características apomórficas deste clado são de otimização ambígua. Das sinapomorfias não ambíguas recuperadas, destaca-se a exposição lateral do basisfenóide no neurocrânio (caráter 266[1]), e sínfise mandibular baixa e convexa anteriormente (caráter 333[3], Figura 10). Gondwanasuchia, por outro lado, é suportada por uma grande quantidade de sinapomorfias, destacando-se o pós-orbital com uma margem anterolateral adicional (caráter 171[1], Figura 11) e várias sinapomorfias póscranianas propostas pela primeira vez por Pol et al. (2012) (396[1], 398[1], 405[1], 409[1], 412[1], 429[1], 446[1] e 462[1]). A inativação destes caracteres pós-cranianos, no entanto, não gera árvores discrepantes da análise completa. Diferentemente do encontrado por Pol et al. (2012), estes caracteres não são fundamentais para a formação do clado Gondwanasuchia, que é recuperado mesmo sem tais caracteres. 
A

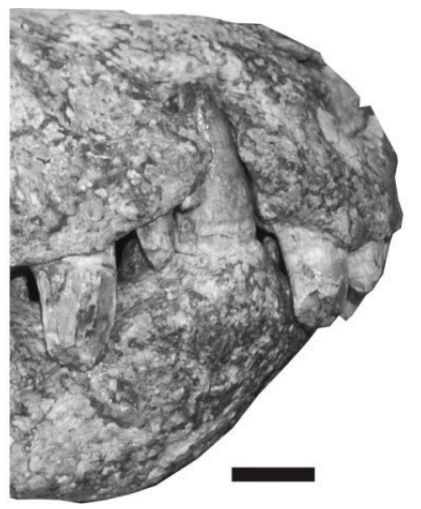

B

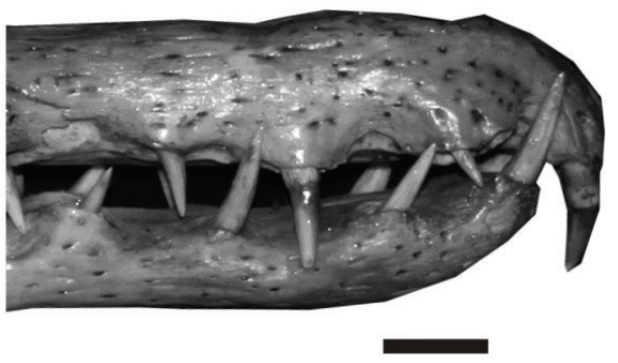

Figura 10. Caráter 333. A- Vista lateral direita da região anterior do rostro e mandíbula de Baurusuchus salgadoensis (MPMA 62-0001-02) em vista lateral exemplificando a sínfise mandibular alta e convexa anteriormente; B- Vista lateral direita da região anterior do rostro e mandíbula de Tomistoma schlegelii (ROM sem número) exemplificando o estado presente em Neosuchia com a sínfise mandibular baixa e convexa anteriormente. Barra de escala $2 \mathrm{~cm}$.

Três análises exploratórias foram feitas para entender as consequências da aproximação de Stolokrosuchus, Araripesuchus, Mahajangasuchidae, Peirosauridae e Trematochampsidae à Neosuchia. Uma análise forçando somente Stolokrosuchus como grupo irmão de Neosuchia gera uma hipótese subótima com 30 passos extras. Dentre os caracteres suportando esta relação inclui-se a exposição lateral do basisfenóide no neurocrânio (caráter 266[1]) que já foi utilizada como uma sinapomorfia de Neosuchia + Stolokrosuchus (Turner \& Buckley 2008, Turner \& Sertich 2010). A aproximação de Peirosauridae + Trematochampsidae (clado 161) à Neosuchia resulta em hipóteses subótimas com 16 passos extras. Quatro características são recuperadas como sinapomorfias não ambíguas para o clado Neosuchia + Peirosauridae + Trematochampsidae (79[1], 156[1], 374[2], 385[1]). Destas, destaca-se a maxila com variações do tamanho do dente formando duas ondas (374[1]), utilizada por Benton \& Clark (1988) como uma sinapomorfia de Neoscuhia. A aproximação de Araripesuchus, Peirosauridae + Trematochampsidae e Mahajnagasuchidae é ainda mais subótima, requerendo 31 passos extras e desestabilizando o consenso estrito, de modo que poucos clados são recuperados. 

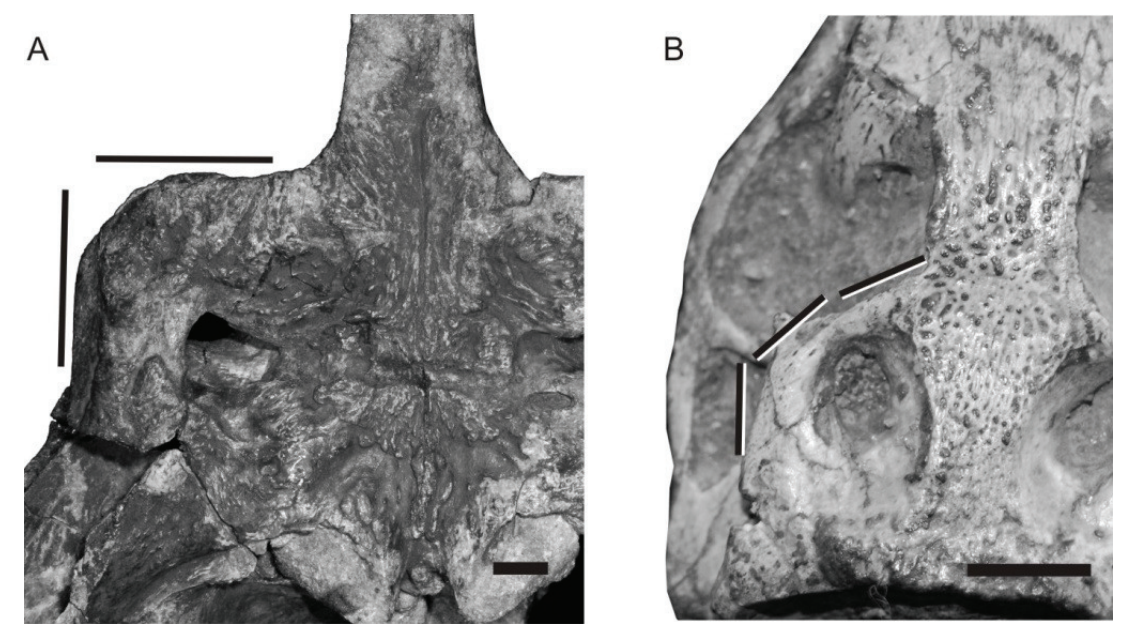

Figura 11. Caráter 489. A- Vista dorsal do crânio de Aegisuchus witmeri (ROM 54530) exemplificando a região dorsal do pós-orbital com margens anterior e lateral apenas; B- Vista dorsal do crânio de Araripesuchus patagonicus (MUCPv 269) exemplificando a região dorsal do pós-orbital com uma margem anterolateral adicional. Barra de escala $1 \mathrm{~cm}$.

\section{V.II.IV. Neosuchia basais}

O primeiro ramo divergente de Neosuchia é Stomatosuchidae como grupo irmão do clado 197. Stomatosuchidae é um grupo de posição filogenética subexplorada, pois o holótipo e único espécime reconhecido de Stomatosuchus (Stromer 1925, 1936), proveniente do Cenomaniano do Egito, foi destruído durante a segunda guerra mundial. A morfologia bizarra deste táxon gigante (até 10 metros de comprimento estimado) com rostro abaulado e fortemente achatado, além da mandíbula frágil, sustentou possível proximidade com os Nettosuchidae (Eusuchia, Alligatorinae) da América do sul (Steel 1973), enquanto Benton \& Clark (1988) e Brochu (2001) sugerem o táxon como Eusuchia basal. Laganosuchus thaumastos e Laganosuchus maghrebensis foram descritos recentemente e atribuídos à Stomatosuchidae (Sereno \& Larsson 2009); paralelamente Aegisuchus witmeri foi descrito e associado à Aegyptosuchus, ambos incluídos em Aegyptosuchidae (Holliday \& Gardner 
2012). As duas análises filogenéticas anteriores, que incluíram estes táxons os posicionam como Neosuchia derivados (Sereno \& Larsson 2009, Holliday \& Gardner 2012), ou mesmo Eusuchia (Holliday \& Gardner 2012). Porém, na análise de Holliday \& Gardner (2012), em que estes táxons foram incluídos concomitantes, estes não formam um clado.

A análise pessoal de Aegisuchus e de novos materiais mais completos associados à Laganosuchus maghrebensis fomentaram a inclusão destes táxons na análise de parcimônia. A morfologia única compartilhada pelos táxons e a formação de um grupo monofilético, sugere que Stomatosuchidae e Aegyptosuchidae representam uma única família. Dentre os caracteres utilizados para a formação do clado, incluí a presença de uma superfície dorsal do parietal portando uma saliência com ornamentação bem definida (486[1]). Um constrain forçando Stomatosuchidae em Eusuchia resulta em árvores com somente 4 passos extras, demonstrando que a posição do clado como Neosuchia basal deve ser visto com cautela. Possíveis sinapomorfias de Stomatosuchus e Eusuchia são 87[0] e 123[1].

Theriosuchus e o clado 196 compartilham três sinapomorfia não ambíguas, ausentes em Stomatosuchidae. Dentre estas, destaca-se a projeção do processo posterolateral do squamosal paralela à superfície do teto craniano (116[0] Figura 12), adquirida paralelamente no clado 163. A posição filogenética de Theriosuchus encontrada na nova filogenia é compatível com um grande número de análises prévias, visto que Stomatosuchidae frequentemente não é incluído (ex.: Buckley et al. 2000, Rogers 2003 Turner \& Calvo 2005, Pol \& Apesteguia 2005, Salisburry et al. 2006, Pol \& Gasparini 2009, Martin et al. 2010, Andrade et al. 2011, Buscalioni et al. 2011). Theriosuchus, na presente análise, sumariza três espécies do gênero, que é o componente emblemático do grupo Atoposauridae (sensu Martin et al. 2010). Atoposauridae apresenta uma extensa distribuição temporal (Jurássico SuperiorMaastrichtiano) sendo um representante recorrente das faunas terrestres Juro-Cretácicas da 
Europa. Porém, registros africanos e norte-americanos podem estender consideravelmente sua distribuição geográfica (Langston 1974, Michard et al. 1990, Rogers 2003).

A

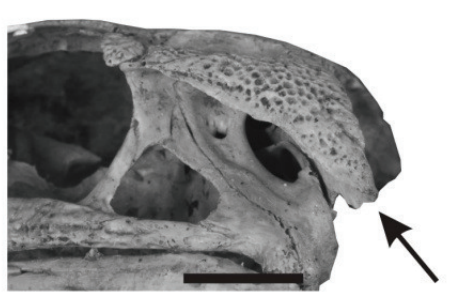

B

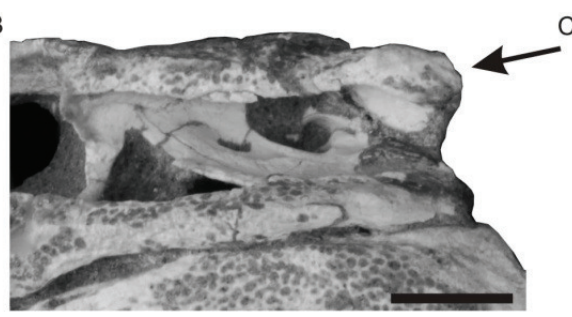

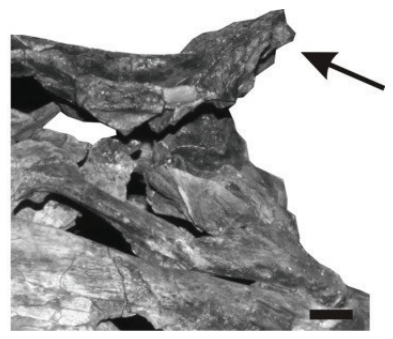

Figura 12. Caráter 116. A- Vista lateral direita da região posterior do crânio de Araripesuchus gomesi (AMNH 24450) exemplificando a projeção do processo posterolateral do squamosal ventralmente direcionado; B- Vista lateral direita da região posterior do crânio de Shamosuchus djadochtaensis (IGM 100/1195) exemplificando a projeção do processo posterolateral do squamosal paralelamente direcionado; C- Vista lateral direita da região posterior do crânio de Kaprosuchus saharicus (MNN-IGU 12) exemplificando a projeção do processo posterolateral do squamosal dorsalmente direcionado. Barra de escala $2 \mathrm{~cm}$.

\section{V.II.V. Neosuchia derivados}

O clado 196 abrange a grande maioria dos Neosuchia da presente análise. No contexto desta discussão, este clado será chamado de Neosuchia derivados. Esta politomia envolve Bernissartia fagesii, Tethysuchia (sensu Andrade et al. 2011, clado 195), Goniopholididae (clado 200) e o clado 201. Em nenhuma árvore mais parcimoniosa Bernissartia é recuperado associado à Tethysuchia, ou mais basal que este clado em relação à Eusuchia. Este resultado é consistente com praticamente todas as hipóteses filogenéticas prévias (ex.: Benton \& Clark 1988, Sereno et al. 2001, 2003, Tykoski et al. 2002, Pol \& Apesteguia 2005, Sereno \& Larsson 2009, Jouve 2009, Pol et al. 2009, 2012, Turner \& Sertich 2010, Pol \& Powell 2011; para contraponto ver Norell \& Clark 1990, Clark \& Norell 1992, Fiorelli \& Calvo 2007). 
A aproximação de Bernissartia ao clado 201 (mais derivado que Tethysuchia e Goniopholididae) corresponde à hipótese mais comunmente reconhecida para o posicionamento deste táxon em análises prévias (ex.: Benton \& Clark 1988, Pol et al. 2004, 2009, 2012, Sereno \& Larsson 2009, Pol \& Powell 2011). Neste contexto, o táxon é tido como de grande importância para o entendimento das características presentes no surgimento de Eusuchia (Dollo 1883, Kälin 1955, Steel 1973, Benton \& Clark 1988, Norell \& Clark 1990, Clark \& Norell 1992, Salisburry et al. 2006, Pol et al. 2009, Salisbury \& Naish 2011). Todavia, a possível associação do táxon à Goniopholididae foi proposta pontualmente em diferentes contextos (Lydekker 1888, Buffetaut 1975, Buscalioni et al. 1984, Turner \& Sertich 2010). Dentre as duas hipóteses, somente a posição de Bernissartia como grupo irmão do clado 201 é mais parcimoniosa na presente análise, com os caracteres 46[2], 215[1], 220[0], 306[0], 466[0] suportando tal relação. Porém, uma análise exploratória forçando a associação de Bernissartia como grupo irmão de Goniopholididae, resulta em árvores mais parcimoniosas somente dois passos mais longas, com os caracteres 257[0] e 389[1] suportando este clado.

Aparte da possível aproximação de Thalattosuchia ao clado, Tethysuchia é recuperado recorrentemente em três posições em Neosuchia, como o representante mais basal do clado (ex.: Pol et al. 2009, Turner \& Sertich 2010, Pol \& Powell 2011, Pol et al. 2012), mais derivado que Atoposauridae e grupo irmão de Goniopholididae e demais Neosuchia (ex.: Pol \& Gasparini 2009, Nascimento \& Zaher 2011, Riff \& Kellner 2011), ou formando um grupo monofilético com Goniopholididae (ex.: Sereno et al. 2001, 2003, Larsson \& Sues 2007, Sereno \& Larsson 2009, Andrade et al. 2011). A posição mais derivada de Tethysuchia em relação à Atoposauridae, recuperada na presente análise, é suportada pela presença de quatro sinapomorfias não ambíguas presente em todas as árvores, destacando a ausência de fenestra antero-orbital (12[1]). Ainda, um grande número de possíveis sinapomorfias é recuperado 
dependendo da resolução da politomia na base do clado 196. Nas árvores mais parcimoniosas em que Goniopholididae e Bernissartia encontram-se mais derivados que Tethysuchia, os caracteres 85[1], 156[1], 312[0] e 389[1] são sinapomórficos do clado 196. Adicionalmente, a possível associação de Tethysuchia e Goniopholididae requer somente um passo extra e apresentam como possíveis sinapomorfias os caracteres 46 [1], 86[1], 261[1] e 467[0]. Os resultados obtidos demonstram uma grande instabilidade nas possíveis relações entre os Neosuchia derivados e novos estudos considerando caracteres relacionados aos grupos, em especial, à Bernissartia, podem auxiliar na resolução destes conflitos.

\section{V.II.VI. Inter-relações de Tethysuchia e posição de Khoratosuchus}

Tethysuchia foi proposto por Andrade et al. (2011) para o clado que agrupa os táxons de rostro alongado pertencentes à Pholidosauridae (Zittel \& Eastman 1902), Dyrosauridae (Stefano 1903) e Elosuchidae (Lapparent de Broin 2002). A formação de Tethysuchia é recorrente em análises prévia (com ou sem a aproximação de Thalattosuchia ao clado). No entanto, dependendo da amostragem taxonômica, tanto Pholidosauridae quanto Dyrosauridae podem ser considerados monofiléticos ou parafiléticos. Na presente análise, Dyrosauridae foi recuperado como monofilético (clado 194) e Pholidosauridae, juntamente com uma forma não descrita associada à Elosuchidae e Khoratosuchus como externos ao clado. A despeito de Khoratosuchus e da forma não descrita, este arranjo foi corroborado em análises gerais de Crocodyliformes (ex.: Sereno et al. 2003, Turner \& Sertich 2010, Andrade et al. 2011, Pol \& Powell 2011, Pol et al. 2012), bem como filogenias focadas em Tethysuchia (Sereno et al. 2001, Barbosa et al. 2008, Hastings et al. 2010, 2011). Porém, outros trabalhos obtém Pholidosauridae como um clado, com ou sem uma amostragem ampla de Dyrosauridae (Jouve et al. 2006, Larsson \& Sues 2007, Jouve 2009, Sereno \& Larsson 2009, Fortier et al. 2011). 
Dentre os caracteres suportando Dyrosauridae, destaca-se o comprimento anteroposterior da fenestra temporal superior muito maior que a órbita (17[1]), paralelamente adquirido em Thalattosuchia. A proposição original de Elosuchidae (Lapparent de Broin 2002) foi estabelecida para englobar uma possível relação de Stolokrosuchus e Elosuchus. Todavia, o clado como originalmente concebido não condiz com a presente análise.

Khoratosuchus jintasakuli, do Cretáceo Inferior da Tailândia, foi inicialmente descrito como Neosuchia, sem proposição mais precisa sobre suas relações filogenéticas. Na presente análise, ele é recuperado como um Tethysuchia, mas devido à quantidade de missing data presente em Khoratosuchus jintasakuli e as politomias dos clados 195 e 196, nenhuma sinapomorfia não ambígua é associada a esse clado. Dentre as características passíveis de codificação para Khoratosuchus que podem ser associadas ao clado, destacam-se o lacrimal mais longo que o pré-frontal (64[0]), a barra pós-orbital muito robusta e com sessão transversal elíptica (170[1]) e a ausência do processo posterior do ectopterigóide (250[0]).

\section{V.II.VII. Inter-relações de Goniopholididae}

Goniopholididae é um dos clados com alto suporte estatístico na presente análise, mas com reduzida amostragem de táxons associados ao grupo (ver Andrade et al. 2011, Salisbury \& Naish 2011). Porém, as relações filogenéticas obtidas na análise de Andrade et al. (2011) encontram-se replicadas, exceto pela aproximação de Sunosuchus e Eutretauranosuchus. O número de sinapomorfias não ambíguas recuperadas para o clado é restrita a somente três, destacando-se a presença de uma crista transversal na superfície dorsal do frontal anterior às órbitas (caráter 81[1], crista inter-orbital transversal Andrade \& Hornung 2011). Este pequeno número de sinapomorfias não ambíguas é enviesado pela grande quantidade de caracteres não

codificados para Sunosuchus. Porém, dos caracteres possivelmente sinapomórficos de 
Goniopholididae encontra-se a presença de uma depressão bem marcada na superfície posterolateral da maxila (caráter 89[1]), homologizada à estrutura presente em Hsisosuchus.

\section{V.II.VIII. Paralligatoridae, Susisuchus, Isisfordia e Eusuchia}

A discussão sobre as inter-relações do clado 201 é crítica para o entendimento das mudanças envolvidas na evolução da morfologia dos crocodiliformes recentes. Porém, as informações disponíveis para esta transição são escassas (Benton \& Clark 1988, Norell \& Clark 1990, Clark \& Norell 1992, Salisburry et al. 2006). Adicionalmente, vários táxons deste contexto não foram incluídos na presente análise, dentre estes, se destacam a Forma de Glen Rose (Langston 1973, 1974), Dolichochampsa minima (Gasparini \& Buffetaut 1980), Gilchristosuchus palatinus (Wu \& Brinkman 1993), Forma de Las Hoyas (Ortega \& Buscalioni 1995), Pachycheilosuchus trinquei (Rogers 2003) e Leiokarionosuchus brookensis (Salisbury \& Naish 2011). A inclusão destes táxons certamente promoveria uma discussão mais robusta sobre a evolução de Eusuchia, que tradicionalmente, e também na presente análise, é centrada em um pequeno número de táxons.

O clado 201 é suportado por uma única sinapomorfia não ambígua, presença de vértebras cervicais procélicas (394[1]). Uma reavaliação importante é o reconhecimento de Susisuchus com o estado apomórfico do caráter, diferentemente de Salisburry et al. (2006) e Pol et al. (2009). A recodificação foi baseada na descrição de novos materiais do táxon com região cervical melhor preservada (Figueiredo et al. 2011).

O clado 205 coresponde à Paralligatoridae (Konzhukova 1954), que é um dos grupos frequentemente ignorados nas análises de Crocodyliformes. No entanto, análises recentes (Turner \& Sertich 2010, Figueiredo et al. 2011, Pol \& Powell 2011, Pol et al. 2012) incluem Rugosuchus e Shamosuchus djadochtaensis, fomentados pela descrição de novos materiais 
deste último (Pol et al. 2009). Ainda sim, uma série de espécies associados ao gênero são ignoradas (Pol et al. 2009, Turner \& Brochu 2011). A inclusão da forma do Maranhão ao clado é segura. Essa associação expande grandemente a ocorrência de Paralligatoridae geograficamente e temporalmente (Montefeltro et al. submetido).

Eusuchia (sensu Buscalioni et al. 2011), não foi recuperado como um clado em todas as árvores. No entanto, em mais de $80 \%$ das árvores, Paralligatoridae é recuperado como grupo irmão dos demais membros do clado 201. Uma análise exploratória forçando esta posição recupera Susisuchus como o grupo irmão de Eusuchia (Crocodylia, Isisfordia e Hylaeochampsidae sensu Buscalioni et al. 2011), como em Salisburry et al. (2006) e Buscalioni et al. (2011). As árvores obtidas também possuem 2447 passos, indicando que este resultado é um subconjunto das árvores mais parcimoniosas recuperadas na análise original. Neste contexto, Susisuchus e Eusuchia compartilham os caracteres 6[0], 100[1], 121[1], 134[0], 355[2], 374[0], 464[3] e 465[0]. Eusuchia por sua vez compartilha o caráter 91[1/2].

A coana exclusivamente bordejada pelo pterigoide e a procelia das vértebras truncais têm sido discutidas desde os primórdios da taxonomia de Crocodyliformes e considerados caracteres importantes para a delimitação de Eusuchia (Huxley 1875, Norell \& Clark 1990, Clark \& Norell 1992, Brochu 1999, Salisburry et al. 2006, Pol et al. 2009). Porém, a descrição e reavaliação de novas formas, conjuntamente com reinterpretações de caracteres impõe uma reavaliação da diagnose tradicional do grupo (Michard et al. 1990, Brochu 1999, Buscallioni et al. 2001, 2011, Salisburry et al. 2006, Pol et al. 2009). Na presente análise, a coana delimitada exclusivamente pelo pterigoide (235[1]) é uma sinapomorfia ambígua de Eusuchia (Susisuchus incerto) com reversão em Pietraroiasuchus. Vértebras truncais procélicas representam uma sinapomorfia ambígua do clado 201, visto o estado plesiomórfico e posição flutuante de Susisuchus. Somente três táxons recentes de Crocodylia foram incluídos na análise (clado 206). Estes foram recuperados como um grupo monofilético. Ainda, houve a 
aproximação de Alligator e Crocodylus como ocorre nas análises morfológicas do grupo (ex.: Brochu 1999).

\section{V.II.IX. Inter-relações basais de Gondwanasuchia}

A politomia basal de Gondwanasuchia envolve os clados Notosuchia (149), Peirosauridae + Trematochampsidae (161), clado 159 (Mahajangasuchidae clado 184 + Sebecidae clado 158) e Doratodon (160). Os possíveis arranjos destes clados são importantes para discutir a validade e monofilia de Sebecia, Sebecosuchia e Notosuchia. Porém, aspectos nomenclaturais precisam ser clarificados para uma discussão adequada. Optou-se por não utilizar a definição filogenética original de Notosuchia estabelecida por Sereno et al. (2001). Esta definição estemática do clado (táxons mais próximos a Notosuchus terrestris que a Crocodylus niloticus) foi proposta prematuramente, baseada em uma análise restrita, que não permitia o entendimento da composição e relações reais do grupo (Turner \& Sertich 2010). A definição é assincrônica com o uso histórico do nome e permite a inclusão de uma série de formas não tradicionalmente associadas ao grupo (ex.: Turner \& Sertich 2010, Pol et al. 2012). A aplicação direta da definição de Sereno et al. (2001) implicaria na equivalência de Notosuchia ao clado Gondwanasuchia (clado 150). Porém, preferiu-se aplicar o nome Notosuchia ao clado 149, para aproximar sua composição ao entendimento histórico do grupo (Gasparini 1971).

Outra idiossincrasia nomenclatural da presente análise foi a nomeação do clado 161 como Peirosauridae + Trematochampsidae. As composições de Trematochampsidae (Buffetaut 1974) e Peirosauridae (Gasparini 1982) são historicamente conectadas, e alguns táxons são atribuídos a um grupo ou outro indiscriminadamente (ex.: Peirosaurus torminni e Hamadasuchus). Esta falta de consistência está em última instância relacionada à possível 
atribuição da espécie tipo de Trematochampsidae (Trematochampsa taqueti) à categoria de nomem dubium. Porém, na presente análise, Trematochampsa taqueti é considerada um táxon válido. A aplicação dos nomes Peirosauridae ou Trematochampsidae ao clado 161 não tem impacto real na discussão sobre a posição e composição do clado, visto que os táxons atribuídos à estas duas famílias formam um grupo monofilético. Enquanto este problema nomenclatural não está resolvido, nenhum dos nomes foi assumido (ver Sertich 2011).

No contexto geral das árvores mais parcimoniosas, o clado formado pelas duas espécies de Doratodon (clado 160) apresentam duas sinapomorfias não ambíguas, destacando-se a presença de duas linhas principais de foramens na região anterior do dentário (494[1] Figura 13). A aproximação de Mahajangasuchidae como grupo irmão de Sebecidae formando o clado 159 é uma relação não proposta em trabalhos prévios. As sinapomorfias não ambíguas recuperadas para o clado são influenciadas pela morfologia bizarra de Mahajangasuchidae associada à presença do táxon Lorosuchus como grupo irmão dos demais Sebecidae. A presença de um crânio platirostral (caráter 8[3]) como sinapomorfia do clado exemplifica esta situação peculiar, sendo revertida no clado 157. Notosuchia (clado 149) apresenta uma série de sinapomorfias não ambíguas. Dentre estas, destaca-se dentes maxilares implantados em um sulco dental comum (caráter 378[1]). Peirosauridae + Trematochampsidae (clado 161) é o clado mais sensível aos possíveis arranjos da politomia basal de Gondwanasuchia, pois todas as sinapomorfias dependem das relações de seus grupos irmãos (ver Apêndice IV).

\section{V.II.IX.1 Sebecia e as possíveis relações basais de Gondwanasuchia}

Considerando todas as árvores mais parciomoniosas, somente dois arranjos são possíveis para a politomia basal de Gondwanasuchia. Em 66\% das árvores existe o agrupamento dos clados a parte de Notosuchia, com Doratodon mais basal do clado. A segunda hipótese recupera 
Doratodon juntamente com Peirosauridae + Trematochampsidae como grupo irmão de Notosuchia, enquanto o clado 159 é basal a estes todos.

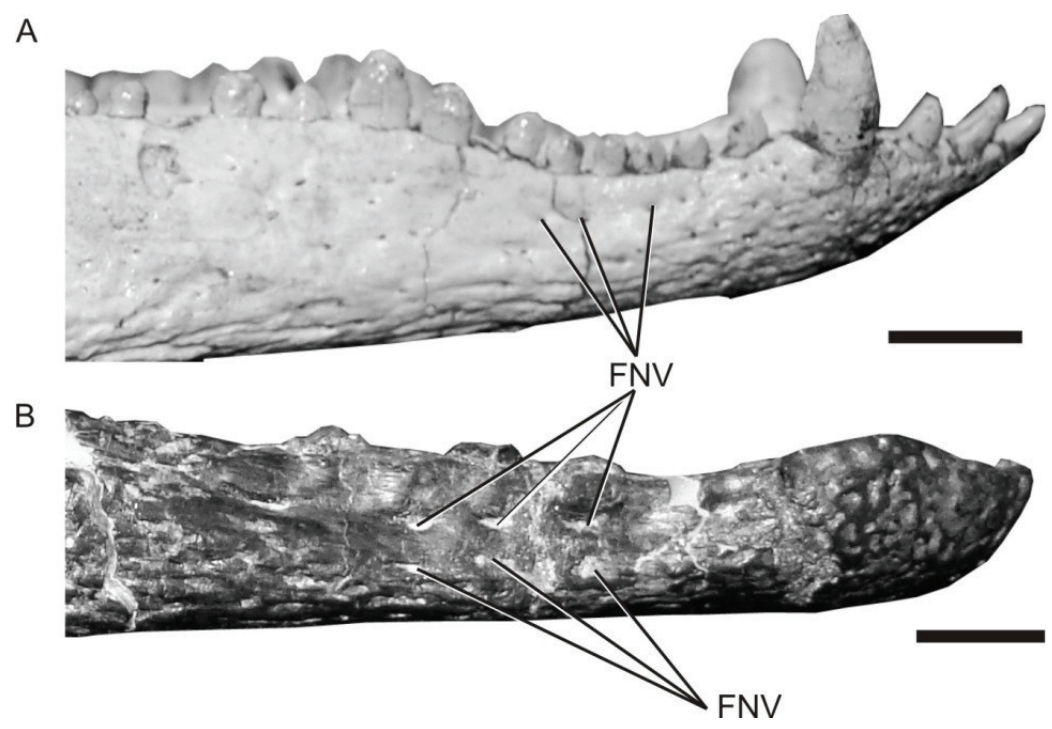

Figura 13. Caráter 494. A- Vista lateral direita da mandíbula de Montealtosuchus arrudacamposi (MPMA-16-007-04) exemplificando a presença de uma linha principal de foramens neurovasculares da região anterior do dentário; B- Vista lateral direita da mandíbula de Doratodon carcharidens (IPUW 234957) exemplificando a presença de duas linhas principais de foramens neurovasculares da região anterior do dentário. Legenda: FNV, foramens neurovasculares. Barra de escala $1 \mathrm{~cm}$.

A primeira hipótese implica em um clado formado majoritariamente pelas formas atribuídas à Sebecia (sensu Sereno \& Larsson 2009), porém, com a inclusão de Mahajangasuchidae e Doratodon. Uma análise experimental forçando a monofilia de Sebecia encontra os caracteres 320[3], 321[1], 341[1] como sinapomorfia do clado. A sutura do dentário e supra-angular complexa, com três projeções posteriores do dentário e duas projeções anteriores do supra-angular (321[1] Figura 14) é destacada, pois já foi considerada como sinapomorfia de Peirosauridae (Turner \& Buckley 2008), e do clado Mahajangasuchidae + Peirosauridae (Turner \& Sertich 2010). Na presente análise, foi possível reconhecer este mesmo estado em Doratodon carcharidens (Figura 14B). Ainda, nesta análise experimental, os táxons de Sebecia mais derivados que Doratodon compartilham 
os caracteres 142[1], 337[1] e 384[1] como sinapomorfias, e Peirosauridae + Trematochampsidae apresenta os caracteres 45[1], 136[1], 200[0] e 371[1]. Dentre as possíveis sinapomorifas de Peirosauridae + Trematochampsidae, a presença de um processo anterior cuneiforme da maxila na região lateral da sutura pré-maxila/maxila (caráter 136[1], Figura 15) também foi recuperada como uma sinapomorfia do clado em diferentes contextos (Gasparini et al. 1991, Turner \& Buckley 2008).

Na hipótese em que o clado Peirosauridae + Trematochampsidae, juntamente com Doratodon, forma o grupo irmão de Notosuchia, esta relação é suportada pelos caracteres 9[0], 39[1], 77[0], 128[1], 330[1], 345[1], 407[1] e 465[0]. Neste contexto ainda, Doratodon é aproximado de Peirosauridae pela presença dos caracteres 213[1] e 320[3], e Peirosauridae é suportado pelo caráter 384[1].
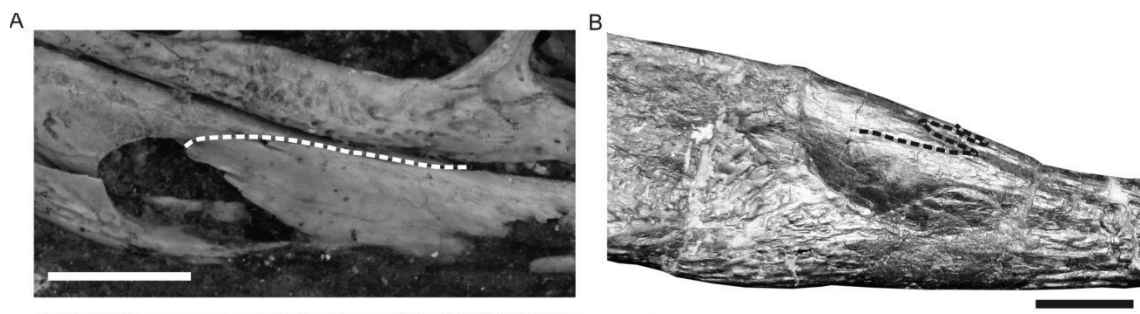

$\mathrm{C}$
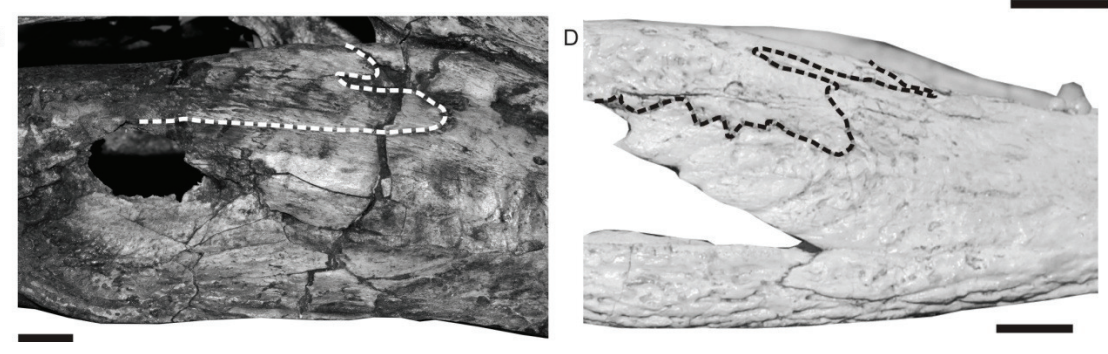

Figura 14. Caráter 321. A- Vista lateral direita da região posterior mandíbula de Araripesuchus gomesi (AMNH 24450) exemplificando a sutura do dentário e supra-angular simples; B- Vista lateral direita da região posterior mandíbula de Doratodon carcharidens (IPUW 234957), C- Vista lateral direita da região posterior mandíbula de Kaprosuchus saharicus (MNN-IGU 12) e D- Vista lateral direita da região posterior mandíbula de Montealtosuchus arrudacamposi (MPMA-16-007-04) exemplificando a sutura do dentário e supra-angular complexa, com três projeções posteriores do dentário e duas projeções anteriores do supra-angular. Barra de escala $1 \mathrm{~cm}$. 


\section{V.II.IX.2 Monofilia de Notosuchia e validade de Sebecosuchia}

Notosuchia, como estabelecido por Gasparini (1971), formado por Notosuchus, Uruguaysuchus e Araripesuchus, mas não incluindo táxons pertencentes à "Mesosuchia", "Thalattosuchia" e "Sebecosuchia", não foi recuperado monofilético em nenhuma das árvores mais parcimoniosas. Baurusuchidae foi recuperado no clado menos inclusivo que congrega estes táxons, como em Sereno \& Larsson (2009), Riff \& Kellner (2011) e Andrade et al. (2011). Adicionalmente, em nenhuma das árvores mais parcimoniosas existe a formação de Sebecosuchia (sensu Pol \& Powell 2011), clado tal que é frequentemente recuperado em análises de Crocodyliformes (ex.: Pol 2003, Gasparini et al. 2006, Fiorelli \& Calvo 2008, Turner \& Buckley 2008, Turner \& Sertich 2010, Pol \& Powell 2011, Pol et al. 2012). Duas análises experimentais foram feitas forçando a monofilia de Sebecosuchia. Na primeira análise, Sebecidae foi forçada como grupo irmão do clado 139. A outra análise exploratória inclui também Doratodon no constrain, baseado na hipótese de Company et al. (2005). Ambas as análises exploratórias recuperam árvores subótimas, possuindo 12 e 17 passos extras respectivamente. Adicionalmente, a topologia de consenso recuperada em ambas as análises inclui Sebecosuchia derivado em Notosuchia, porém menos resolvida que a análise original. Na primeira análise exploratória a formação de Sebecosuchia é sustentada pela presença dos caracteres 53[1], 134[0], 138[1], 246[1] e 313[1], destacando -se a presença do forâmen intramandibulares muito grande (slot like 313[1]), enquanto na segunda análise o clado é suportado pela sutura parietal e pós-orbital ausente da superfície dorsal do crânio, mas presente na região ventral da fossa supratemporal (caráter 97[1]) e coroas dentárias na região

mediana e posterior das maxilas e dentários fortemente comprimidas labiolingualmente (caráter 358[2]). 


\section{V.II. X. Inter-relações do Clado 159}

A dicotomia basal do clado 159 representa em um ramo Mahajangasuchidae (clado 184) e Sebecidae (clado 158). Mahajangasuchidae é um dos clados com maior suporte estatístico da análise, com 20 sinapomorfias presentes em todas as árvores mais parcimoniosas (ver Apêndice IV). A existência do clado não foi questionada nas análises prévias em que Mahajangasuchus e Kaprosuchus foram incluídos concomitantemente (Sereno \& Larsson 2009, Turner \& Sertich 2010 e Andrade et al. 2011). Todavia, a possível associação de Mahajangasuchus à Peirosauridae, proposta em trabalhos prévios, fomentou uma análise exploratória forçando a aproximação da família ao clado Peirosauridae + Trematochampsidae. Esta análise resultou em árvores mais parcimoniosas 4 passos mais longos, com o caráter relacionado à concavidade para a recepção de um dente caniniforme da maxila na superfície lateral do dentário no nível do sétimo dente (caráter 315[1]) como sinapomorfia do clado.

Sebecidae, na presente análise, é formada por Lorosuchus como grupo irmão dos demais táxons, incluindo Bergisuchus e Iberosuchus. Este arranjo é diferente do proposto por Pol \& Powell (2011) e Pol et al. (2012), em que estes últimos são posicionados externos aos demais táxons. O clado 157, por sua vez, é formado por uma politomia envolvendo a grande maioria de Sebecidae juntamente com o clado 156, que reúne Ayllusuchus externo à Bretesuchus e Iberosuchus. Uma importante diferença em relação às análises prévias é a codificação de Iberosuchus exclusivamente baseada no holótipo do táxon. Assim, a quantidade de caracteres codificáveis para o táxon foi reduzida. Esta medida foi tomada, pois os materiais adicionais do táxon, ou não apresentam porções anatômicas sobrepostas às do holótipo (Ortega et al. 1996) ou não estão formalmente descritos (Ortega 2004). Dentre as sinapomorfias de Sebecidae, se destaca as asas do pterigoide com sessão transversal arredondada (caráter 246[1] Figura 16). Adicionalmente, um novo caráter relacionado à presença de um par de foramens na região anterior da superfície ventral do palatino (caráter 
487 Figura 17) é recuperado como sinapomorfia ambígua do clado, dado o estado incerto em Lorosuchus.
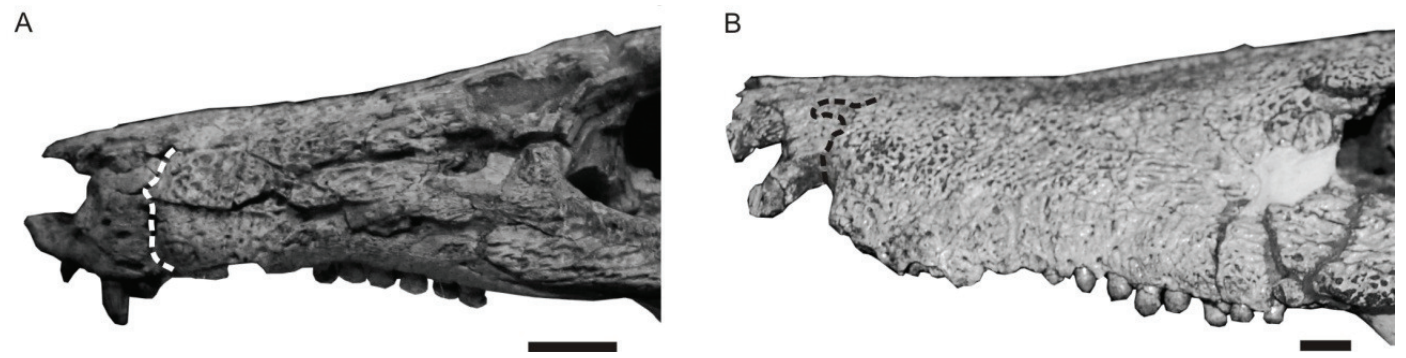

Figura 15. Caráter 136. A- Vista lateral esquerda da região anterior do rostro de Araripesuchus wegneri (MNN GAD 20) exemplificando a ausência do processo anterior cuneiforme da maxila na região lateral da sutura pré-maxila/maxila; B- Vista lateral esquerda da região anterior do rostro de Lomasuchus palpebrosus (MOZ 4084 PV) exemplificando a presença do processo anterior cuneiforme da maxila na região lateral da sutura pré-maxila/maxila. Barra de escala $1 \mathrm{~cm}$.

\section{V.II. XI. Inter-relações de Peirosauridae + Trematochampsidae}

Peirosauridae + Trematochampsidae é formado por três níveis de arranjos politómicos. O primeiro nível envolve os táxons sul-americanos Uberabasuchus, Montealtosuchus, Lomasuchus e Gasparinisuchus além do clado 163. O segundo nível é a politomia do clado 163, envolvendo os táxons originalmente incluídos no Gênero Trematochampsa (Trematochampsa taqueti e Miadanasuchus oblita, clado 166), clado 162 (Hamadasuchus + Peirosaurus) e o clado 164. E o terceiro nível é formado pela politomia envolvendo Itasuchus, Pepesuchus, Stolokrosuchus e o clado 165. As posições recuperadas para os táxons Peirosaurus, Lomasuchus, Uberabasuchus e Hamadasuchus são contrastantes com o as relações propostas previamente. Estes táxons formam um clado na maioria das análises, em especial, naquelas com amostragem restrita (ex.: Gasparini et al. 1991, Pol \& Norell 2004ab, Pol et al. 2004, 2009, Jouve et al. 2006, Turner \& Buckley 2008, Jouve 2009), mas também 
em análises com uma amostragem relativamente ampla de táxons deste contexto (Turner \& Sertich 2010). Estes novos arranjos podem estar relacionadas à maior amostragem da presente análise com a inclusão concomitante de táxons negligenciados em análises prévias (Itasuchus jesuinoi, Trematochampsa taqueti e Miadanasuchus oblita), táxons pela primeira vez incluídos em uma filogenia (Pepesuchus e Barreirosuchus) e uma forma ainda não descrita (Forma de Ingall). Dentre as sinapomorfias do clado 163, ausentes em Uberabasuchus, Montealtosuchu, Lomasuchus e Gasparinisuchus, destaca-se a presença do torus sagital no ramo palatal das maxillas (caráter 214[1] Figura 18), utilizado inicialmente como sinapomorfia de Sebecia (Larsson \& Sues 2007).

Diferentemente das análises proferidas em Larsson \& Sues (2007) e Turner \& Buckley (2008), a inclusão de Trematochampsa não resulta no aumento de hipóteses mais parcimoniosas. Uma análise experimental excluindo os táxons Trematochampsa taqueti e Miadanasuchus oblita não resolveu nenhuma das politomias encontradas na análise completa. Adicionalmente, Trematochampsa taqueti e Miadanasuchus oblita apresentam um ancestral comum exclusivo, diferentemente do estudo de Simons \& Buckley (2009), que propõe a transferência de T. oblita para o gênero Miadanasuchus. Porém, a codificação do táxon Miadanasuchus foi feita com base nos materiais fragmentários descritos (Buffetaut \& Taquet 1979, Rasmunsson 2002, Simons \& Buckley 2009) sendo que novos materiais mais completos podem auxiliar no melhor entendimento das relações deste táxon (ver Sertich 2011). 

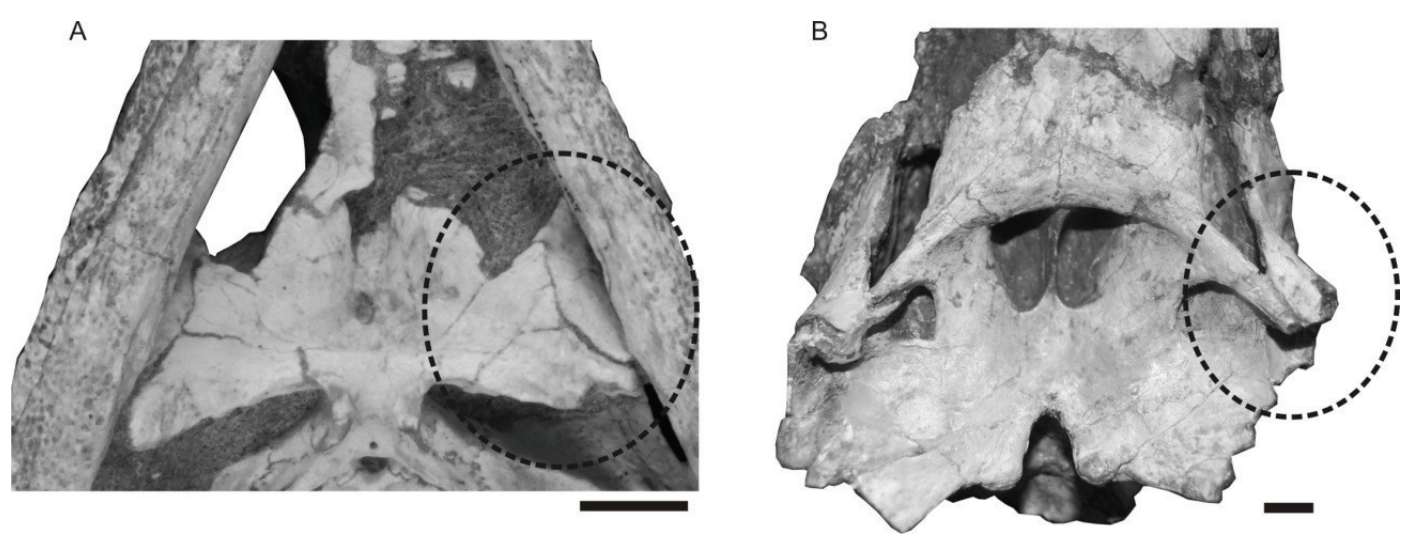

Figura 16. Caráter 246. A- Vista ventral da região posterior do crânio de Shamosuchus djadochtaensis (IGM 100/1195) exemplificando a asa do pterigoide laminar; B- ventral da região posterior do crânio de Sebecus querejazus (MHCN-P 3701) exemplificando a asa do pterigoide com sessão transversal arredondada. Barra de escala $1 \mathrm{~cm}$.
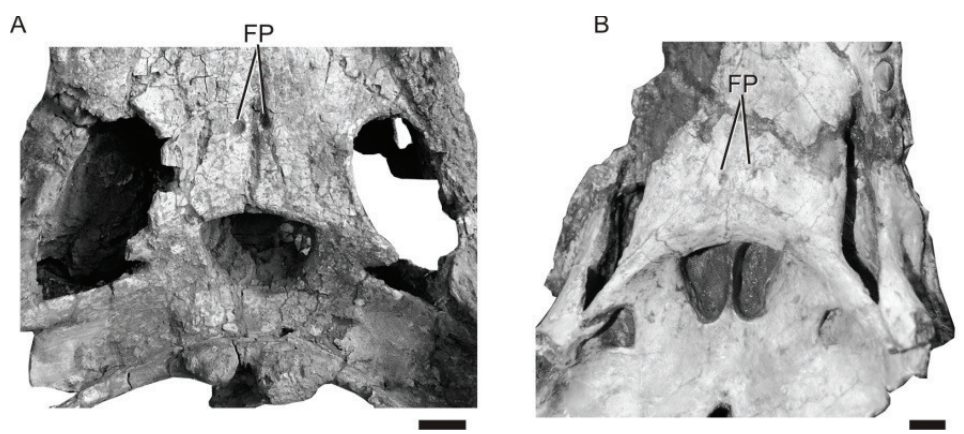

$\mathrm{C}$

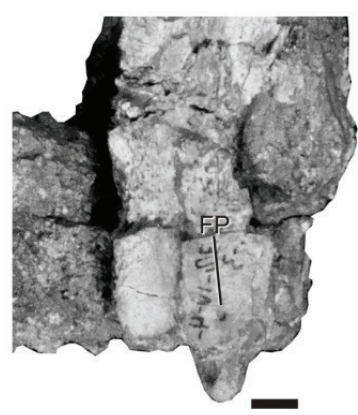

Figura 17. Caráter 487 recuperado como sinapomorfia ambígua de Sebecidae. A- Vista ventral da região posterior do crânio de Bretesuchus bonapartei (PVL 4735), B- Vista ventral da região posterior do crânio de Sebecus querejazus (MHCN-P 3701) e C- Vista ventral da região posterior do crânio de Ayllusuchus fernandezi (MLP 72-X-4-2) apresentando um par de foramens localizados na região anterior da superfície ventral do palatino. Legenda: FP, forâmen palatino. Barra de escala $1 \mathrm{~cm}$.

O clado 164 é recuperado pela primeira vez na presente análise e agrupa uma série de formas de morfologia discrepante dos demais componentes de Peirosauridae + Trematochampsidae. Estes táxons apresentam crânio longirosto (incerto em Barreirosuchus e Forma de Ingall) que é associado ao hábito semi-aquático (Busbey 1995, Brochu 2001, Campos et al. 2011). Adicionalmente, dentre as sinapomorfias do clado, encontra-se a ausência de aberturas extras no quadrado (caráter 193[0] Figura 19), adquirida 
independentemente em outros grupos com o hábito aquático e semi-aquático como Thalattosuchia, Stomatosuchidae e Tethysuchia (Montefeltro \& Larsson 2011, 2012).
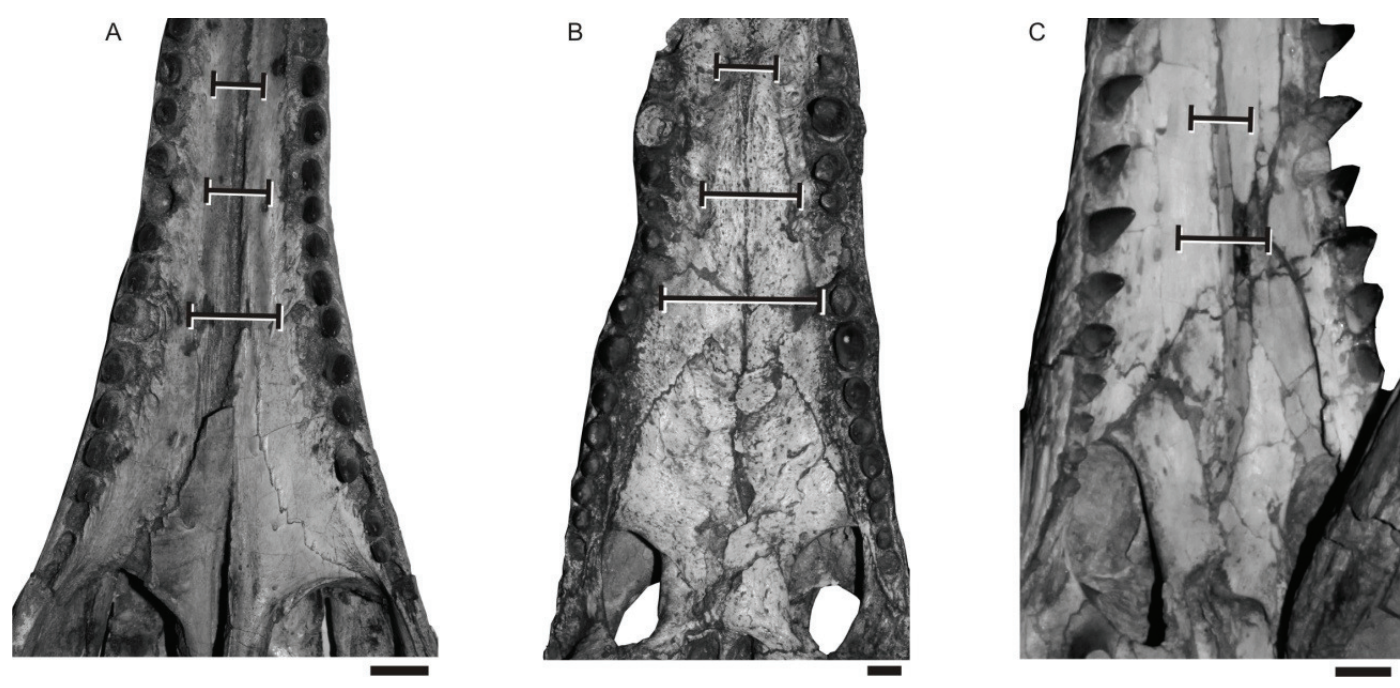

Figura 18. Caráter 214[1] recuperado como sinapomorfia do clado 163. A- Vista ventral da região mediana do crânio de Stolokrosuchus lapparenti (MNN GDF 600), B- Vista ventral da região mediana do crânio de Hamadasuchus rebouli (ROM 52620) e C- Vista ventral da região mediana do crânio de Pepesuchus deiseae (MN 7005 V) apresentando um torus sagital no ramo palatal das maxillas. Barra de escala $1 \mathrm{~cm}$.

\section{V.II. XII. Monofilia de Araripesuchus e Uruguaysuchidae}

As espécies associadas à Araripesuchus foram recuperadas como o clado mais basal de Notosuchia, como em grande parte das análises filogenéticas (Pol \& Norell 2004ab, Pol et al. 2004, Pol \& Apesteguia 2005, Zaher et al. 2006, Turner \& Buckley 2008, Fiorelli \& Calvo 2008, Leardi \& Pol 2009, O’Connor et al. 2010, Riff \& Kellner 2011, Nascimento \& Zaher 2011, Iori \& Carvalho 2011). Dentre as sinapomorfias não ambíguas suportando o clado destaca-se a morfologia da sutura pré-maxila/maxila em formato de fenda ao longo de toda a sutura (caráter 45[2]). 

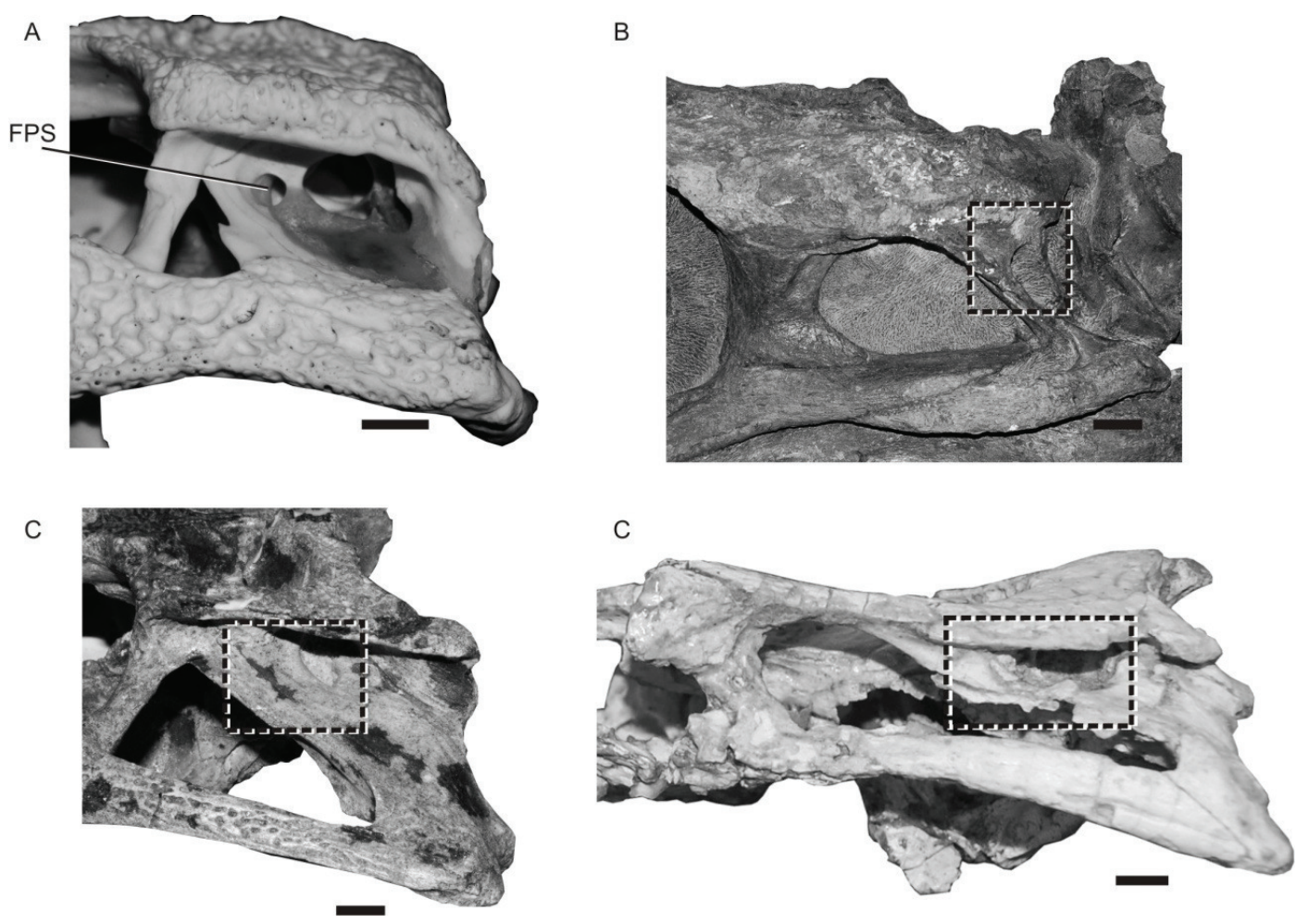

Figura 19. Caráter 193. A- Vista lateral direita da região posterior do crânio de Osteolaemus tetraspis (ROM 6533) exemplificando a presença de aberturas extras à abertura ótica do quadrado; B- Vista lateral direita da região posterior do crânio de Dakosaurus andiniensis (MOZ 6146P, invertido), CVista lateral direita da região posterior do crânio de Stolokrosuchus lapparenti (MNN GDF 600), DVista lateral direita da região posterior do crânio de Dyrosauridae Bolívia (MHNCN- sem número) exemplificando a ausência de aberturas extras à abertura ótica do quadrado adquiridos independentemente. Legenda: FPS, forâmen pré-ótico do sifão. Barra de escala $1 \mathrm{~cm}$.

Araripesuchus wegneri foi recuperado como o grupo irmão das demais espécies do gênero, como em Pol \& Apesteguia (2005), Turner (2006), Soto (2011), Pol \& Powell (2011) e Pol et al. (2012). As espécies de Araripesuchus mais derivadas que A. wegneri compartilham uma única sinapomorfia presente em todas as árvores (22[2]), porém, muitas potenciais sinapomorfias do clado dependem dos arranjos da politomia do clado 174 (ver Apêndice IV). Adicionalmente, o estudo de novos materiais associados ao táxon Araripesuchus rattoides permite confidentemente a inclusão do táxon no gênero, mesmo que a posição do táxon em relação aos demais não seja resolvida. 
Duas das análises bases da presente revisão filogenética recuperam as espécies de Araripesuchus em arranjos parafiléticos (Sereno \& Larsson 2009, Turner \& Sertich 2010). Uma análise exploratória forçando a parafilia do gênero resulta no acréscimo de um único passo nas árvores mais parcimoniosas. Neste caso, a parafilia de Araripesuchus é causada pela posição de Urugauysuchus como grupo irmão de dos representantes de Araripesuchus aparte de A. wegneri. Adicionalmente, Anatosuchus se posiciona como grupo irmão do clado Uruguaysuchus + "Araripesuchus".

$\mathrm{Na}$ topologia de consenso, Uruguaysuchus foi recuperado como grupo irmão dos demais Notosuchia (clado 147). Dentre os caracteres suportando o clado 148 (topologicamente equivalente a Ziphosuchia de Turner \& Sertich 2010), destaca-se a sutura pré-maxila/maxila confluente em toda sua extensão (caráter 44[0]). Trabalhos recentes, incluindo informações provenientes de um novo espécime de Uruguaysuchus, encontram um clado que circunscreve este táxon como grupo irmão de Araripesuchus (Soto et al. 2011, Pol \& Powell 2011, Pol et al. 2012). Baseados nestas análises, o nome Uruguaysuchidae é aplicado para o grupo, como originalmente concebido (Gasparini 1971). As informações provenientes do novo espécime descrito foram incorporadas na presente análise, porém Uruguaysuchidae (Araripesuchus + Uruguaysuchus) não está presente nas árvores mais parcimoniosas. Uma análise exploratória forçando estas mesmas relações (Uruguaysuchidae e Araripesuchus monofiléticos) gera árvores mais parcimoniosas somente três passos mais longos. Porém, muitas relações do entorno do clado são colapsadas e nenhuma sinapomorifa é recuperada em todas as árvores. Neste contexto, os caracteres 107[1], 305[0], 325[1], 331[1], 341[0], 358[1] são possíveis sinapomorfias de Uruguaysuchidae. Dentre estes possíveis caracteres, destaca-se a presença da superfície oclusal da sínfise mandibular fortemente côncava (331[1]) utilizada como sinapomorfia de Uruguaysuchidae por Soto et al. (2011). 


\section{V.II. XIII. Relações basais do clado 147}

As primeiras linhagens divergentes do clado 147 incluem uma série de formas gonduânicas cuja associação à Notosuchia não foi contundentemente contestada, exceto para Anatosuchus minor. Porém, as posições relativas destes táxons são contraditórias nas diferentes análises (ex.: Turner 2006, Pol et al. 2009, Sereno \& Larsson 2009, Turner \& Sertich 2010, O'Connor et al. 2010, Andrade et al. 2011, Pol et al. 2012). No presente estudo, o primeiro ramo divergente do clado 147 é formado pelo clado agrupando Candidodon + Libycosuchus e Anatosuchus + Simosuchus. Este clado (180), por sua vez, é grupo irmão daquele que congrega Mallawisuchus + Pakasuchus + clado 144, sendo estes últimos grupos irmãos. O clado 144 é formado por Comahuesuchus como grupo irmão do clado que congrega o clado $142+$ Notosuchus e as duas espécies do Gênero Mariliasuchus (clado 177). Estas relações não apresentam suporte estatístico robusto, como recorrentemente observado nas hipóteses previamente apresentadas. Em última instância, isso pode ser relacionada à similaridade morfológica dos táxons envolvidos neste contexto (Turner \& Sertich 2010).

Na presente análise, o clado 180 representa Candidodontidae como definido por Montefeltro et al. (2009), com uma inclusividade inesperada e englobando formas de morfologia díspar. Entre as sinapomorfias não ambíguas do clado, destaca-se o contato amplo entre o pós-orbital e quadradojugal (caráter 180[1]) adquirido paralelamente em formas do grupo externo (ex.: Protosuchus haughtoni), alguns esfagessáuridos (ex.: Armadillosuchus) e Baurusuchidae. A aproximação de Candidodon e Libycosuchus é dada por duas sinapomorfias não ambíguas de distribuição homoplástica, destacando-se os dentes pré-maxilares posteriores muito mais longos que os dentes anteriores (caráter 372[1]).

A aproximação de Simosuchus e Anatosuchus é dada por uma série de sinapomorfias não ambíguas, incluindo a presença de uma crista na superfície ventral da região proximal do 
pterigóide (caráter 241[1]) e parte da sínfise composta pelo dentário com margem anterior extensa e orientada perpendicularmente ao eixo sagittal da mandíbula (caráter 335[2]). A união desses dois táxons de morfologia bizarra corrobora a hipótese de Sereno \& Larsson (2009), que é contrastante com as outras hipóteses em que ambos foram incluídos concomitantemente (Sereno et al. 2003, Martinelli 2003, Fiorelli \& Calvo 2007, 2008, Andrade et al. 2008b, Jouve 2009, Turner \& Sertich 2010, Andrade et al. 2011). No entanto, devido às composições taxonômicas e distintas topologias destas análises, uma comparação adequada das posições relativas de Anatosuchus e Simosuchus é intangível. Não obstante, duas análises exploratórias foram proferidas para averiguar posições alternativas destes táxons. A primeira análise exploratória forçou a não monofilia do clado 179, enquanto a segunda análise forçou a monofilia de Anatosuchus + Mahajangasuchidae seguindo os resultados de Fiorelli \& Calvo (2008) e Andrade et al. (2011). A não monofilia do clado 179 gera árvores mais parcimoniosas com somente um passo extra, mas resulta na aproximação de Anatosuchus a um clado contendo Uruguaysuchus e Araripesuchus parafilético (como na análise exploratória para a não monofilia de Araripesuchus apresentada no item V.II.XII). Nesta mesma análise, Simosuchus é recuperado como o grupo irmão de Libycosuchus como em Jouve (2009) e Turner \& Sertich (2010). A aproximação de Anatosuchus à Mahajangasuchidae, por outro lado, gera hipóteses com 12 passos extras e com os caracteres 8[3], 13[1], 240[1], 336[1], 464[0] suportando esta relação. Dentre estas, destaca-se o caráter relacionado à fenestra antero-orbital em forma de fenda (13 [1]).

$\mathrm{Na}$ presente análise, Candidodon não possui um ancestral comum exclusivo com Malawisuchus como em muitas análises filogenéticas prévias (Pol \& Norell 2004ab, Pol et al. 2004, Pol \& Apesteguia 2005, Zaher et al. 2006, Turner \& Buckley 2008). Uma das sinapomorfias do possível clado é a presença de dentes com cúspides adicionais arranjadas em mais de uma linha. $\mathrm{Na}$ nova análise, o caráter relacionado à presença de dentes 
multicuspidados foi submetido à codificação contingencial, deste modo, a presença de dentes multicuspidados foi considerado sinapomorfia do clado 148 revertida no clado 144 . Adicionalmente, a presença de Pakasuchus como grupo irmão do clado 144 suporta a presença de dentes com cúspides acessórias arranjadas em mais de uma linha também como uma sinapomorfia mais abrangente em Notosuchia (Montefeltro et al. 2009, O'Connor et al. 2010).

A posição de Comahuesuchus, Mariliasuchus e Notosuchus mais próximos de Sphagesauridae, Baurusuchidae e Sebecidae (quando Sebecosuchia é monofilético) é uma relação comummente reconhecida em análises prévias, mesmo com considerável discrepância de amostragem taxonômica (Martinelli 2003, Zaher et al. 2006, Turner \& Buckley 2008, Fiorelli \& Calvo 2008, Pol \& Gasparini 2009, Sereno \& Larsson 2009, Pol et al. 2009, 2012, Turner \& Sertich 2010, Andrade et al. 2011, Nascimento \& Zaher 2011, Pol \& Powell 2011). Dentre as sinapomorfias suportando o clado (144), destaca-se a morfologia peculiar do palatino expandindo lateroposteriormente em um processo de sessão transversal arredondada (caráter 230[1], Figura 20, Andrade et al. 2006).

Dentre as características sinapomórifcas que sustentam a posição mais derivada de Mariliasuchus e Notosuchus em relação à Comahuesuchus, destaca-se a presença de múltiplas fenestras no quadrado (caráter 194[1] Figura 21). Deste modo, Notosuchidae (sensu Turner \& Sertich 2010) não inclui Comahuesuchus, diferentemente de Zaher et al. (2006), Pol et al. (2009, 2012), Pol \& Powell (2011) e Nascimento \& Zaher (2011). Na presente análise, Notosuchidae é suportada por uma série de caracteres, destacando-se a presença de fenestras palatais anteriores (caráter 223[1] Figura 22), condição única em Notosuchia (Andrade \& Bertini 2008b, Turner \& Sertich 2010), além da presença de dente com morfologia transicional na sutura pré-maxila/maxila (caráter 379[1]) reconhecido recentemente (Lecuona \& Pol 2008). 
A
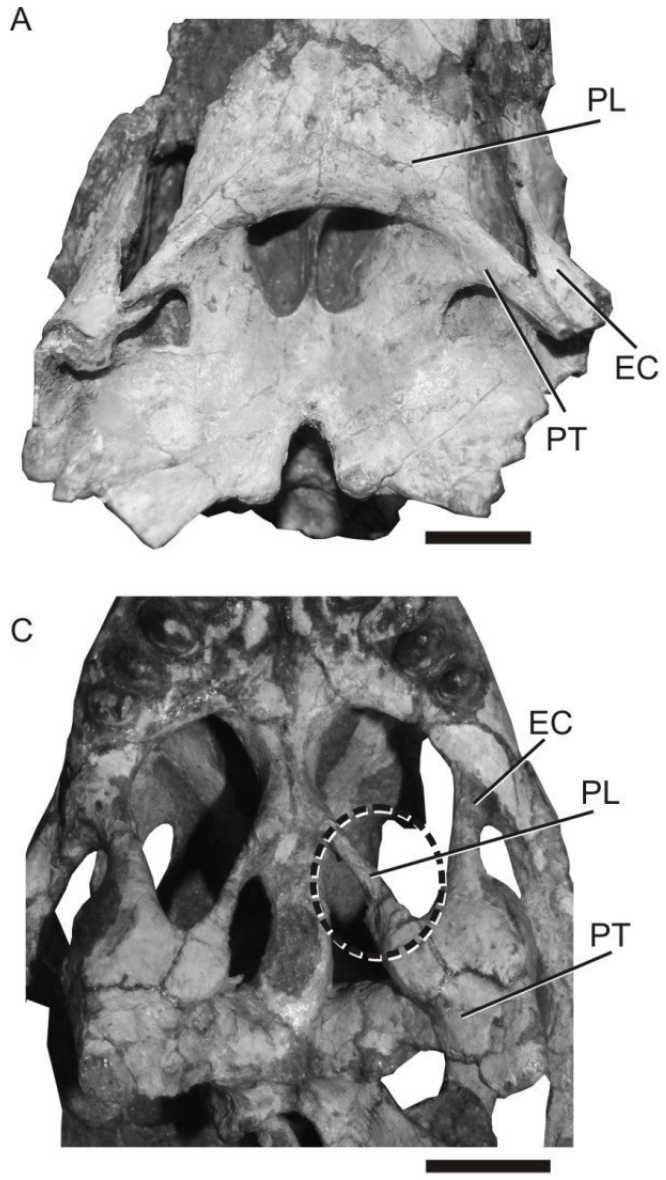

B
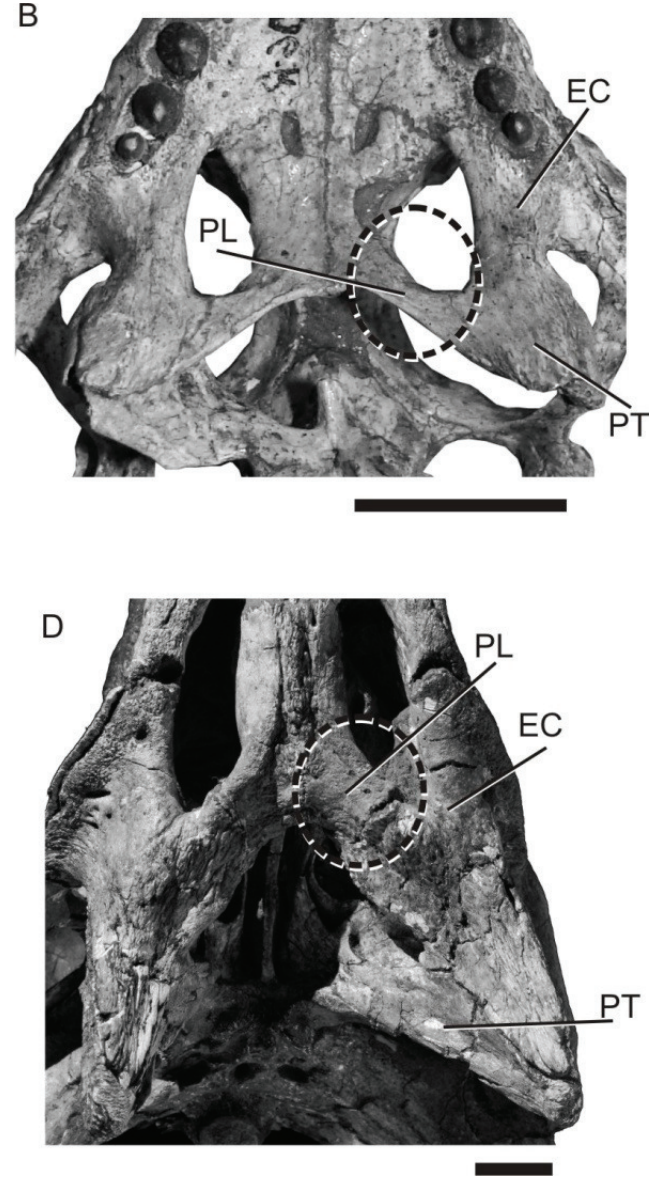

Figura 20. Caráter 230. A- Vista ventral da região posterior do crânio de Sebecus querejazus (MHCNP 3701) exemplificando o eixo anteroposterior do palatino paralelo ao longo de todo o comprimento; B- Vista lateral ventral da região posterior do crânio de Mariliasuchus amarali (UFRJ-D-106-R), CVista lateral ventral da região posterior do crânio de Caipirasuchus paulistanus (MPMA 67-00001/00), D- Vista lateral ventral da região posterior do crânio de Pissarrachampsa sera (LPRP/USP 0018) exemplificando o eixo anteroposterior do palatino expandindo lateroposteriormente em um processo de sessão transversal arredondada. Legenda: EC, ectopterigóide, PL, palatino, PT, pterigóide. Barra de escala $1 \mathrm{~cm}$.

\section{V.II. XIV. Inter-relações dos Notosuchia derivados}

O clado 142 reúne uma dicotomia envolvendo Sphagesauridae (Kuhn 1968, clado 169) e Baurusuchia (Montefeltro et al. 2011, clado141). Os componentes deste clado compartilham uma série de sinapomorfias (ver Apêndice IV), destacando a presença de fossas paracoanais 
na superfície ventral do pterigóide (caráter 236[1], Figura 23) e ausência da parede anterior das aberturas dos tubos eustaquianos laterais (caráter 276[1]).
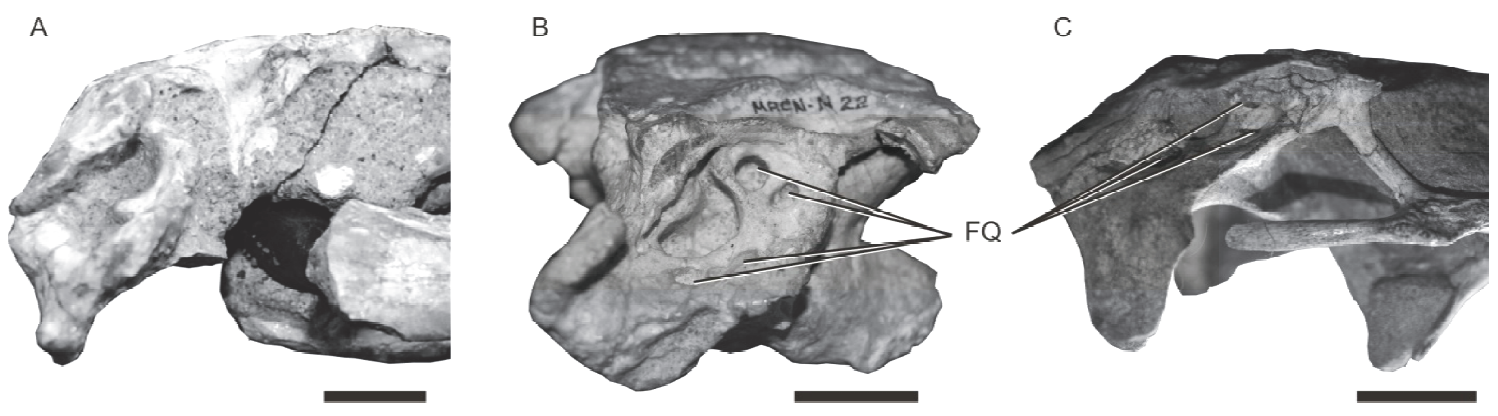

Figura 21. Caráter 194. A- Vista lateral da região posterior do crânio de Comahuesuchus brachybuccalis (MUCP-PV 202) exemplificando a ausência de aberturas extras à abertura ótica do quadrado; B- Vista lateral da região posterior do crânio Notosuchus terrestris (MACN-PV-RN 23), CVista lateral da região posterior do crânio Yacarerani boliviensis (MNK-PAL 5063) exemplificando a presença de aberturas extras à abertura ótica do quadrado. Legenda: $F Q$, fenestras do quadrado. Barra de escala $1 \mathrm{~cm}$.

Posições mais apicais para Baurusuchidae e Sphagesauridae em Notosuchia são geralmente recuperadas, independentemente da Monofilia de Sphagesauridae e Sebecosuchia, mas com variações nas inter-relações destes clados com outros Notosuchia (ex.: Andrade et al. 2008a, Turner \& Sertich 2010, Riff \& Kellner 2011, Montefeltro et al. 2011, Andrade et al. 2011). Esta relação é particularmente estável na análise de Pol (2003) e suas expansões subsequentes (Pol \& Norell 2004ab, Pol \& Apesteguia 2005, Pol \& Gasparini 2009, Pol et al. 2009, 2012, Pol \& Powell 2011), nas quais Sphagesauridae forma um grupo monofilético com Sebecosuchia. Quatro sinapomorfias foram recuperadas para o clado por Pol et al. (2012). Destas, a presença de fossas paracoanais na superfície ventral do pterigoide é a única recuperada na presente análise para o clado 142. Seguindo a discussão de Montefeltro et al. (2011, p 22), a presença de uma depressão triangular na superfície lateral do jugal não foi incluída. A região antero-orbital do jugal mais expandida que a região infraorbital (caráter 149[1]) não foi considerada apomórfica para o clado, pois Pissarrachampsinae (clado 154), 
não incluído em Pol et al. (2012), apresenta o estado plesiomórfico. Finalmente, a implantação dos dentes maxilares em alvéolos, não foi recuperada, devido à recodificação de Mariliasuchus também com esta condição posicionado imediatamente externa ao clado 142 (caráter 378[0], Figura 24).

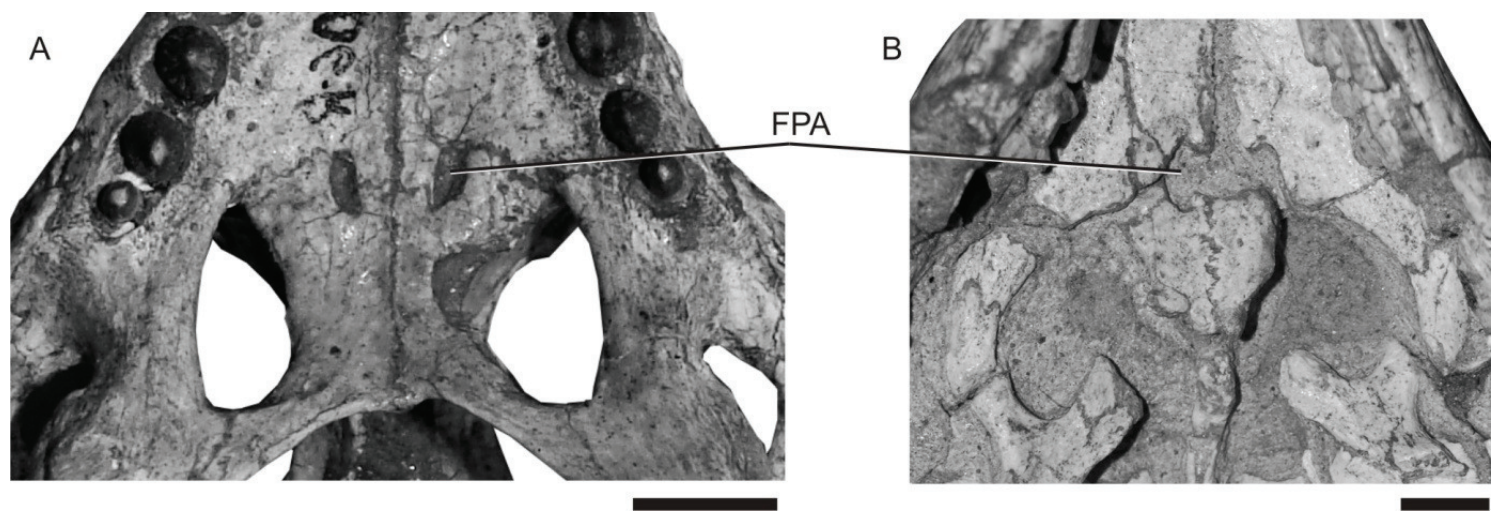

Figura 22. Caráter 223. A- Vista ventral da região palatal média do crânio de Mariliasuchus amarali (UFRJ-D-106-R), B- Vista ventral da região palatal média do crânio de Notosuchus terrestris (MACNPV-RN 1038) exemplificando a presença de fenestras palatais anteriores. Legenda: FPA, fenestras palatais anteriores. Barra de escala $1 \mathrm{~cm}$.

\section{V.II. XV. Sphagesauridae}

Sphagesauridae foi proposto por Kuhn (1968) englobando somente os dois dentes isolados de morfologia única de Sphagesaurus huenei (Price 1950). A utilização de uma família distinta para o táxon foi inicialmente debatida (Gasparini 1971; Steel 1973; Bonaparte 1978), mas posteriormente aceita tendo em vista a descrição de materiais mais completos e de outros táxons possivelmente próximos a Sphagesaurus (Kellner et al. 1995; Kellner \& Campos, 1999; Pol 2003; Marinho \& Carvalho 2007, 2009; Andrade \& Bertini 2008a, Vasconcelos \& Carvalho 2010, Turner \& Sertich 2010, Iori \& Carvalho 2011). No entanto, uma vez que nenhuma definição formal foi proposta, a composição real do grupo é obscurecida pela aplicação do nome a diferentes conjuntos taxonômicos. Os principais pontos 
de controvérsia são a possível inclusão de Adamantinasuchus navae e Chimaerasuchus paradoxus no clado (ver Marinho \& Carvalho 2009, Turner \& Sertich 2010, Kellner et al. 2011a, Iori \& Carvalho 2011).

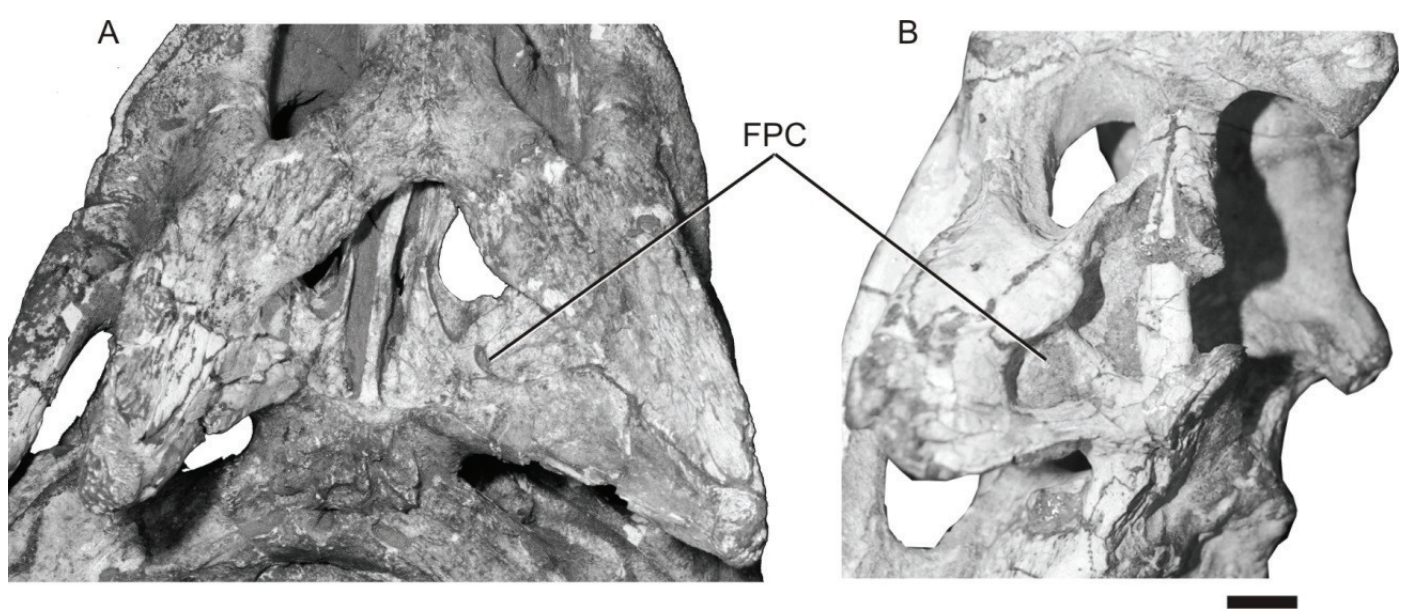

Figura 23. Caráter 236[1] recuperado como sinapomorfia do clado 142. A- Vista ventral da região coanal do crânio de Pissarrachampsa sera (LPRP/USP 0018), B- Vista ventral da região coanal do crânio de Sphagesaurus montealtensis (MPMA 15001/90) exemplificando a presença fossas paracoanais na superfície ventral do pterigoide. Legenda: FPC, fenestras paracoanais. Barra de escala $1 \mathrm{~cm}$.

Na presente análise, o nome Sphagesauridae foi aplicado ao clado 169, pois este reúne todos os táxons consensualmente incluídos no grupo (Sphagesaurus, Armadillosuchus e Caipirasuchus), bem como Adamantinasuchus, que também é frequentemente incluído (Marinho \& Carvalho 2007, 2009, Iori \& Carvalho 2011). Assim, Sphagesauridae engloba também Yacarerani boliviensis e o fragmentário Labidiosuchus amicum, mas não Chimaerasuchus paradoxus. Sphagesauridae é caracterizado por uma série de sinapomorfias, dentre estas, destaca-se a presença de um intervalo separando a série de foramens neurovasculares na região lateral da maxila (caráter 141[1]) e caracteres relacionados à morfologia única da dentição destes táxons, como a implantação obliqua dos dentes maxilares e dentários (caráter 359[2]) e a compressão assimétrica das coroas dentárias conferindo 
formato de gota à sessão transversal dos dentes (caráter 360[1]). Este resultado contrasta com análises prévias que não encontram Adamantinasuchus próximo à Sphagesaurus, mas a outros Notosuchia como Notosuchus, Mariliasuchus e Comahuesuchus (Fiorelli \& Calvo 2008, Novas et al. 2009, O’Connor 2010, Turner \& Sertich 2010, Iori \& Carvalho 2011).

Chimaerasuchus paradoxus é um táxon de morfologia enigmática proveniente do Cretáceo Inferior da China. Este é baseado em materiais fragmentários, incluindo um rostro com dentição conspícua formada por dentes maxilares molariformes multicuspidados. Sua inclusão em Notosuchia foi proposta desde a descrição inicial (Wu et al. 1995) e repetidamente recuperada em análises filogenéticas em diferentes contextos, especialmente, associado à táxons atribuídos à Sphagesauridae (ex.: Wu \& Sues 1996, Pol 2003, Pol \& Apesteguia 2005, Jouve et al. 2006, Fiorelli \& Calvo 2008, Novas et al. 2009, Turner \& Sertich 2010, Iori \& Carvalho 2011, Pol et al. 2012). Porém, Marinho \& Carvalho (2007, 2009), sem uma análise filogenética, sugerem a exclusão de Chimaerasuchus de Sphagesauridae. Adicionalmente, Jouve (2009) propõe uma posição consideravelmente diferente, como um crocodiliforme basal e aproximado de Edentosuchus e a Forma de Kayenta.

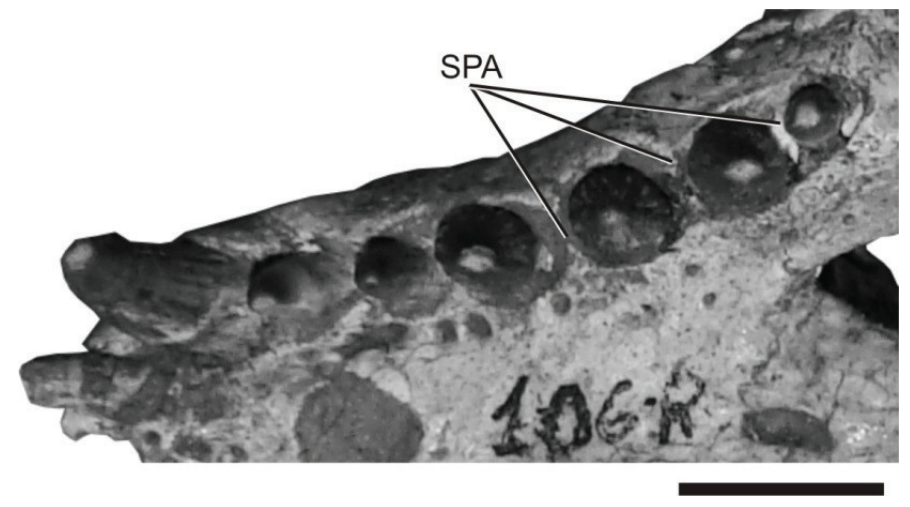

Figura 24. Caráter 378[0] dentes implantados em alvéolos isolados na maxila exemplificado em Mariliasuchus amarali (UFRJ-D-106-R). Legenda: SPA, septo alveolar. Barra de escala $1 \mathrm{~cm}$. 
Duas análises exploratórias foram proferidas para avaliar posições alternativas de Chimaerasuchus na presente base de dados. Uma análise forçou a aproximação de deste táxon a Sphagesauridae e recuperou topologias somente três passos mais longos. Estas topologias encontram a presença de cristas acessórias nas superfícies labial e lingual dos dentes posteriores como única sinapomorfia não ambígua do clado (caráter 366[1]) e o consenso estrito apresenta a mesma estrutura geral da análise original. A segunda análise testou a hipótese heterodoxa de Jouve (2009), mantendo Chimaerasuchus excluído de Mesoeucrocodylia. As árvores mais parcimoniosas obtidas com este constrain são onze passos mais longos que a análise original e recuperam Chimaerasuchus em uma politomia envolvendo também Hsisosuchus, um clado com Fruitachampsa, Zosuchus, Sichuanosuchus e Shantungosuchus, além de Meoseucrocodylia. No que tange a Notosuchia, esta análise apresenta profundos rearranjos no clado 144. Neste caso, o clado 144 é formado por uma dicotomia envolvendo em um ramo Baurusuchidae (clado 139) e no outro Comahuesuchus externo à Notosuchidae (clado 177) + Sphagesauridae politômico (incluindo Morrinhosuchus). Neste caso, Sphagesauridae só apresenta sinapomorfias não ambíguas em algumas árvores, sendo suportado pelos caracteres 13[2] e 360[1].

\section{V.II. XVI. Baurusuchia e Baurusuchidae}

Montefeltro et al. (2011) propuseram duas definições filogenéticas com base nos resultados de sua análise filogenética. Baurusuchidae foi proposto como um clado de definição nodal e Baurusuchia como um clado de definição estemática. Naquele trabalho, ambas as definições circunscrevem o mesmo clado, mas a aplicação das definições no contexto amplo da presente análise apontam dois clados diferentes. Baurusuchia circunscreve o clado 141 enquanto Baurusuchidae circunscreve o clado 139. Baurusuchia foi proposto baseado em um possível 
gap morfológico entre os representantes de Baurusuchidae e seus grupos irmão imediatos. Na presente análise, os táxons Chimaerasuchus e Morrinhosuchus representam os Baurusuchia não Baurusuchidae. Baurusuchia é delimitado por três sinapomorfias, destacando-se a sutura pré-maxila/maxila aberta ventralmente (caráter 44[1]). Porém, a morfologia desta abertura em ambos os Baurusuchia não-Baurusuchidae é diferente do estado encontrado nos Baurusuchidae. Morrinhosuchus apresenta a abertura da sutura em formato de fenda, adquirida paralelamente em Araripesuchus (caráter 46[2]). Chimaerasuchus, por outro lado, apresenta a morfologia mais comummente encontrada, com a abertura pouco desenvolvida e restrita à região ventral da sutura (caráter 46[0]). Chimaerasuchus compartilha com Baurusuchidae três sinapomorfias não ambíguas, dentre estas, a maxila não estendendo posteriormente à margem anterior da órbita em vista lateral (caráter 142[1]). A posição recuperada para Morrinhosuchus é condizente com a única análise filogenética prévia que incluiu este táxon (Iori \& Carvalho 2011), enquanto a posição de Chimaerasuchus representa uma relação não anteriormente proposta.

O clado 139 engloba uma politomia envolvendo Eremosuchus, Pehuenchesuchus, Cynodontosuchus e o clado 138. Considerando as árvores mais parcimoniosas, dois arranjos são recuperados. Estes dois arranjos tem influência direta na aplicação da definição nodal de Baurusuchidae, pois Cynodontosuchus é incluído como um especificador interno do clado (Montefeltro et al. 2011, p. 21). Em 75\% das árvores mais parcimoniosas existe a aproximação de Cynodontosuchus e Pehuenchesuchus em politomia com o clado 138, enquanto em 25\% das árvores, Cynodontosuchus e Eremosuchus encontram-se em politomia com o clado formado por Pehuenchesuchus + clado 138. Em ambas as hipóteses, a politomia é causada pelo colapso de zero-lengths branchs que foram colapsados pela "regra I" de (Codding \& Scharff 1994). Optou-se por assinalar o nome Baurusuchidae paro o clado 139, englobando Eremosuchus e Pehuenchesuchus. 
A maioria dos táxons envolvidos no contexto das relações basais de Baurusuchidae são fragmentários, sendo difícil definir sinapomorfias não ambíguas para Baurusuchidae e seus clado internos (Montefeltro et al. 2011). De qualquer forma, Baurusuchidae é suportada por 4 sinapomorfias não ambíguas (ver Apêndice IV), destacando-se as carenas mesial e distal dos dentes com dentículos homogêneos (caráter 357[1]). Uma importante recodificação foi o reconhecimento de Pehuenchesuchus com o mesmo estado dos demais Baurusuchidae para este caráter (Figura 25). Esta codificação é diferente de Turner \& Calvo (2005) e Pol \& Powell (2011) em que este táxon é recuperado como o Sebecosuchia mais basal devido à ausência de carenas serrilhadas.

O clado 138 é suportado apenas por uma sinapomorfia não ambígua presente em todas as árvores, dente dentário oposto à sutura pré-maxila-maxila duas vezes maior que os outros dentes do dentário (caráter 384[1]). Pabweshi pakistanensis juntamente com Eremosuchus e Pehuenchesuchus representam táxons que foram excluídos a priori da análise de Baurusuchidae por Montefeltro et al. (2011), que sugeriram afinidade destas espécies à Sebecia. Porém, no contexto da nova análise, estes são considerados Baurusuchidae. O clado 137 é formado pela dicotomia Pissarrachampsinae (clado 154) e Baurusuchinae (clado 136), incluindo os representantes mais completos do grupo. Estes resultados corroboram a hipótese proposta por Montefeltro et al. (2011), sendo Campinasuchus dinizi incluído como o táxon mais basal de Pissarrachampsinae. Devido a natureza fragmentária de seus grupos irmão sucessivos, poucas são as sinapomorfias não ambíguas dos dois clados. 


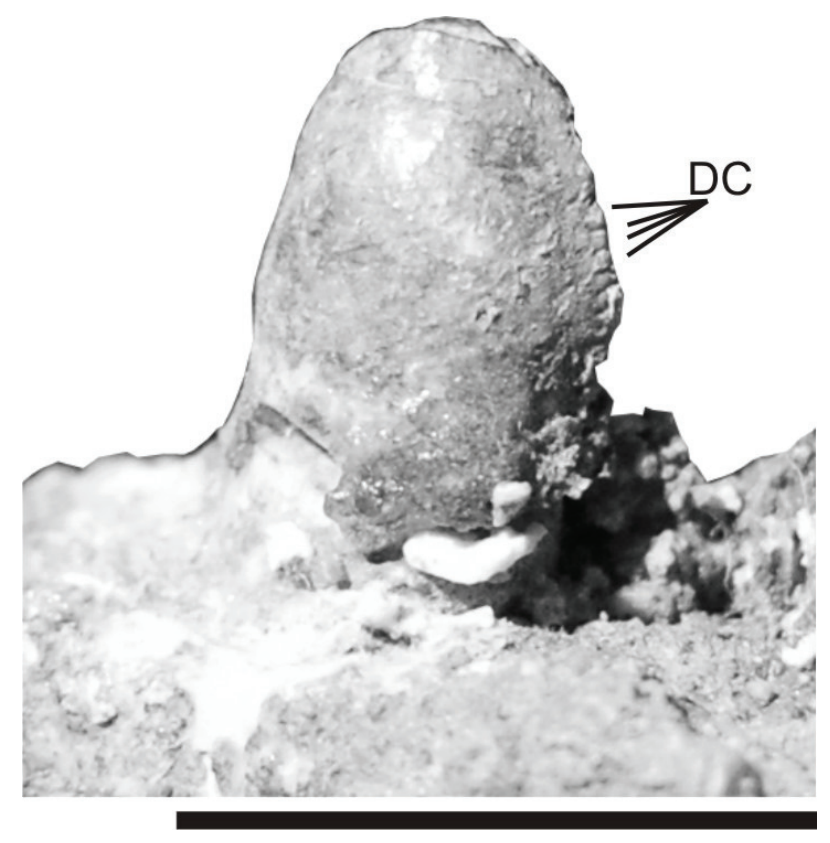

Figura 25. Caráter 357[1] carena dentária com dentículos homogêneos exemplificado em Pehuenchesuchus enderi (MAU-PV-CRS 440). Legenda: DC, dentículos da carena. Barra de escala 1 $\mathrm{cm}$.

\section{CONCLUSÕES}

Considerando esta revisão filogenética dos Mesoeucrocodylia, e as relações nesta estabelecidas, as árvores mais parcimoniosas resultantes, as principais conclusões do presente trabalho são:

- Apesar da grande quantidade de missing data presente em todos os táxons, incluindo alguns táxons muito fragmentários, as 3575 árvores mais parcimoniosas concordam na maioria das relações recuperadas.

- A despeito do foco da análise ser o clado Mesoeucrocodylia dois pontos de consenso na filogenia de Crocodylomopha e Crocodyliformes foram corroborados: Crocodyliformes é um grupo monofilético e Protosuchia, como originalmente concebido, é parafilético. 
- Mesoeucrocodylia forma um clado, porém Fruitachampsa não é incluído.

- Thalattosuchia e Metasuchia representam a dicotomia basal dos Mesoeucrocodylia. A inclusão de Thalattosuchia em Neosuchia como grupo irmão de Tethysuchia resulta em hipóteses filogenéticas menos parcimoniosas.

- A filogenia interna de Thalattosuchia recupera o clado Metriorhynchidae, mas não Geosaurinae e Metriorhynchinae. Adicionalmente, o táxon tratado como Cricosaurus da Colômbia, pode realmente representar um Cricosaurus, mas a associação à Racheosaurus também é possível.

- Metasuchia é formado por uma dicotomia basal com Neosuchia em um ramo e Gondwanasuchia em outro. Neosuchia possui a composição taxonômica próxima à definição original. Gondwanasuchia é formada por Doratodon, Peirosauridae + Trematochampsidae, Sebecidae + Mahajangasuchidae e Notosuchia.

- Stomatosuchidae representa uma radiação basal de Neosuchia seguido de Theriosuchus. Bernissartia, Goniopholididae e Thetysuchia (incluindo Khoratosuchus) encontram-se em uma politomia juntamente com um clado englobando Paralliagatoridae, Susisuchusi e táxons atribuídos à Eusuchia.

- Notosuchia, como originalmente concebido, não é monofilético, pois os táxons originalmente incluídos no grupo encontram-se parafileticamente arranjados em relação à Baurusuchidae. Os táxons atribuídos à Peirosauridae e Trematochampsidae formam um clado. Sebecidae é monofilético e grupo irmão de Mahajangasuchidae.

- Nas inter-relações basais de Gondwanasuchia recuperadas, Sebecosuchia (sensu Pol \& Powell 2011) não é monofilético, enquanto Sebecia (sensu Larsson \& Sues 2007) representa uma hipótese possível de monofilia.

- Araripesuchus representa uma irradiação basal de Notosuchia, mas não forma clado com Uruguaysuchus. 
- Os padrões gerais genealógicos gerais de Baurusuchidae propostos por Montefeltro et al. (2011) são mantidos. Adicionalmente, Eremosuchus, Pehuenchosuchus e Pabwheshi são inseridos no grupo, enquanto Chimaerasuchus e Morrinhosuchus representam os táxons de Baurusuchia não Baurusuchidae. 


\section{REFERÊNCIAS BIBLIOGRÁFICAS}

Andrade, M. B., \& R. J. Bertini. 2008a. A new Sphagesaurus (Mesoeucrocodylia: Notosuchia) from the Upper Cretaceous of Monte Alto City (Bauru Group, Brazil), and a revision of the Sphagesauridae. Hystorical Biology 20:101-136.

Andrade, M. B., \& R. J. Bertini. 2008. Morphological and Anatomical observations about Mariliasuchus amarali and Notosuchus terrestris (Mesoeucrocodylia) and their relationships with other South American notosuchians. Arquivos do Museu Nacional 66:5-62.

Andrade, M. B., \& J. J. Hornung. 2011. A new look into the periorbital morphology of Goniopholis (mesoeucrocodylia: neosuchia) and related forms. Journal of Vertebrate Paleontology 31:352368.

Andrade, M. B., R. J. Bertini, \& A. E. P. C. Pinheiro. 2006. Observations on the palate and choanae structures in Mesoeucrocodylia (Archosauria, Crocodylomorpha): phylogenetic implications. Revista Brasileira de Paleontologia 9:323-332.

Andrade, M. B., R. Edmonds, M. Benton, \& R. Schouten. 2011. A new Berriasian species of Goniopholis (Mesoeucrocodylia, Neosuchia) from England, and a review of the genus. Zoological Journal of the Linnean Society 163:S66-S108.

Antunes, M. T. 1975. Iberosuchus, crocodile Sébécosuchien nouveau. L'Eocène ibérique au nord de la Chalne centrale, et l'origine du canyon de Nazaré. Comunicações dos Serviços Geologicos de Portugal 59:285-330.

Barbosa, J. B., A. W. A. Kellner, \& M. S. S. Vianna. 2008. New dyrosaurid crocodylomorph and evidences for faunal turnover at the K-P transition in Brazil. Proceedings of the Royal Society of London B 275:1-7.

Barriel, V., \& P. Tassy. 1998. Rooting with multiple outgroups: consensus versus parsimony. Cladistics 14:193-200.

Benton, M., \& J. M. Clark. 1988. Archosaur phylogeny and the relationships of the Crocodylia; pp. 295-338 in M. Benton (ed.), The Phylogeny and Classification of the Tetrapods. Clarendon Press, Oxford.

Berg, D. 1966. Die Krokodile, insbesonderfe Asiatosuchus und aff. Sebecus? aus dem Eozän von Messel bei Darmstadt/Haessen. Abhandlungen des Hessischen Landesamtes fur Bodenforschung 52:1-105. 
Bonaparte, J. F. 1978. El Mesozoico de América del Sur y sus Tetrápodos. Opera Lilloana 26:1-596.

Bocquentin-Villanueva, J., \& J. P. S. Filho. 1990. O crocodiliano sul-americano Carandaisuchus como sinonimia de Mourasuchus (Nettosuchidae). Revista Brasileira de Geociências 20:230233.

Brazeau, M. D. 2011. Problematic character coding methods in morphology and their effects. Biological Journal of Linnean Society 104:489-498.

Bremer, K. 1994. Branch support and tree stability. Cladistics 10:295-304.

Brochu, C. A. 1999. Phylogenetics, taxonomy, and historical biogeography of Alligatoroidea. Journal of Vertebrate Paleontology Memoir 6:9-100.

Brochu, C. A. 2001. Crocodylian snouts in space and time: phylogenetic approaches toward adaptive radiation. American Zoologist 41:564-585.

Brochu, C. A. 2003. Phylogenetic approaches toward crocodylian history. Annual Review of Earth and Planetary Sciences 31:357-397.

Brochu, C. A., \& G. W. Storrs. 2012. A giant crocodile from the plio-pleistocene of kenya, the phylogenetic Relationships of neogene african crocodylines, and the antiquity of Crocodylus in africa. Journal of Vertebrate Paleontology 32:587-602.

Brochu, C. A., J. R. Wagner, S. Jouve, C. D. Sumrall, \& L. D. Desmore. 2009. A Correction Corrected: Consensus Over the Meaning of Crocodylia andWhy It Matters. Systematic Biology 58:1-7.

Bronzati, M. F., F. C. Montefeltro, \& M. C. Langer. 2012. A species-level supertree of Crocodyliformes. Historical Biology 24:598-606.

Brown, B. 1934. A change of names. Science 79:80.

Buckley, G. A., \& C. A. Brochu. 1999. An enigmatic new crocodile from the Upper Cretaceous of Madagascar. Special Papers in Palaeontology 60:149-175.

Buckley, G. A., C. A. Brochu, D. W. Krause, \& D. Pol. 2000. A pug-nosed crocodyliform from the Late Cretaceous of Madagascar. Nature 405:941-944.

Buffetaut, E. 1974. Trematochampsa taqueti, un Crocodilien nouveau du Sénonien inférieur du Niger. Comptes Rendus de l'Académie Des Sciences 279:1749-1752. 
Buffetaut, E. 1975. Sur l'anatomie et la position systématique de Bernissartia fagesii Dollo, L., 1883, Crocodilien du Wealdien de Bernissart, Belgique. Bulletin de L'Institut Royal des Sciences Naturelles de Belgique 30:1-20.

Buffetaut, E. 1976. Ostéologie et affinités de Trematochampsa taqueti (Crocodylia, Mesosuchia) du Sénonien inférieur d'In Beceten (République du Niger). Géobios 9:143-198.

Buffetaut, E. 1982. Radiation évolutive, paléoécologie et biogégraphie des crocodiliens mésosuchiens. Mèmoires de la Société Géologique de France 142:1-88.

Buffetaut, E. 1982b. A ziphodont mesosuchian crocodile from the Eocene of Algeria and its implication for vertebrate dispersal. Nature 300:176-178.

Buffetaut, E. 1985. Présence de Trematochampsidae (Crocodylia, Mesosuchia) dans le Crétacé supérieur Du Brésil. Implications paléobiogéographiques. Comptes Rendus de l'Académie Des Sciences 319:348-350.

Buffetaut, E. 1989. A new ziphodont mesosuchian crocodile from the Eocene of Algeria. Palaeontographica 208:1-10.

Buffetaut, E. 1991. Itasuchus Price, 1955; pp. 348-350 in J. G. Maysei (ed.), Santana Fossils: an Illustrated Atlas. TFH Publications Inc., Neptune.

Buffetaut, E. 1994. A new crocodilian from the Cretaceous of southern Morocco. Comptes Rendus de l'Académie Des Sciences 319:1563-1568.

Buffetaut, E., \& P. Taquet. 1979. Un nouveau Crocodilien mésosuchien dans le Campanien de Madagascar, Trematochampsa oblita, n. sp. Bulletin de la Société Géologique de France 23:183-188.

Busbey, A. B. 1995. The structural consequences of skull flatening in crocodilians; pp. 173-192 in J. Thomason (ed.), Functional Morphology in Vertebrate Paleontology. Cambridge University Press, New York.

Buscalioni, A. D., E. Buffetaut, \& J. L. Sanz. 1984. An immature specimen of the crocodilian Bernissartia from the Lower Cretaceous of Galve (Province of Teruel, Spain). Paleontology 27:809-813.

Buscalioni, A. D., \& J. L. Sanz. 1988. Phylogenetic relationships of the Atoposauridae (Archosauria, Crocodylomorpha). Hystorical Biology 1:233-250. 
Buscalioni, A. D., J. L. Sanz, \& M. L. Casanovas. 1992. A new species of the eusuchian crocodile Diplocynodon from the Rocene of Spain. Neues Jahrbuch fur Geologie und Palaontologie, Abhandlungen 187:1-29.

Buscalioni, A. D., F. Ortega, D. B. Weishampel, \& C. M. Jianu. 2001. A revision of the Crocodyliform Allodaposuchus precedens from the Upper Cretaceous of the Hateg Basin, Romania. Its relevance in the Phylogeny of Eusuchia. Journal of Vertebrate Paleontology 21:74-86.

Buscalioni, A. D., P. Piras, R. Vullo, M. Signore, \& C. Barbera. 2011. Early eusuchia crocodylomorpha from the vertebrate-rich Plattenkalk of Pietraroia (Lower Albian, southern Apennines, Italy). Zoological Journal of the Linnean Society 163:S199-S227.

Carvalho, I. S., L. C. B. Ribeiro, \& L. S. Avilla. 2004. Uberabasuchus terrificus sp. nov., a new Crocodylomorpha from the Bauru Basin (Upper Cretaceous), Brazil. Gondwana Research 7:975-1002.

Carvalho, I. S., A. C. A. Campos, \& P. H. Nobre. 2005. Baurusuchus salgadoensis, a new Crocodylomorpha (Cretaceous), Brazil. Gondwana Research 8:11-30.

Cau, A., \& F. Fanti. 2010. The oldest known metriorhynchid crocodylian from the Middle Jurassic of North-eastern Italy: Neptunidraco ammoniticus gen. et sp. nov. Gondwana Research 19:550565.

Chiappe, L. M. 1988. A new trematochampsid crocodile from the Early Cretaceous of north-western Patagonia, Argentina and its palaeobiogeographical and phylogenetic implications. Cretaceous Research 9:379-389.

Clark, J. M. 1986. Phylogenetic relationships of the crocodylomorph archosaurs. University of Chicago, 556 pp.

Clark, J. M. 1994. Patterns of evolution in Mesozoic Crocodyliformes; pp. $84-97$ in N. C. Fraser \& H.D. Sues (eds.), In the Shadow of Dinosaurs. Cambridge University, Cambridge.

Clark, J. M. 2011. A new shartegosuchid crocodyliform from the Upper Jurassic Morrison Formation of western Colorado. Zoological Journal of the Linnean Society 163:S152-S172.

Clark, J. M., \& M. A. Norell. 1992. The Early Cretaceous Crocodylomorph Hylaeochampsa vectiana from the Wealden of the Isle of Wight. American Museum Novitates 3032:1-19. 
Clark, J. M., H.-D. Sues, \& D. Berman. 2000. A new specimen of Hesperosuchus agilis from the Upper Triassic of New Mexico and the Interrelationships of basal crocodylomorph archosaurs. Journal of Vertebrate Paleontology 20:683-740.

Clark, J. M., \& H.-D. Sues. 2002. Two new basal crocodylomorph archosaurs from the Lower Jurassic and the monophyly of the Sphenosuchia. Zoological Journal of the Linnean Society 136:7795.

Clark, J. M., X. Xu, C. A. Forster, \& Y. Wang. 2004. A Middle Jurassic 'sphenosuchian' from China and the origin of the crocodylian skull. Nature 430:1021-1024.

Coddington, J., \& N. Scharff. 1994. Problems with Zero-length branches. Cladistics 10.

Colbert, E. H. 1946. Sebecus, representative of a peculiar suborder of fossil crocodilia from Patagonia. Bulletin of American Museum of Natural History 87:217-270.

Company, J., X. P. Suberbiola, J. I. Ruiz-Omeñaca, \& A. D. Buscalioni. 2005. A new species of Doratodon (Crocodyliformes: Ziphosuchia) from the Late Cretaceous of Spain. Journal of Vertebrate Paleontology 25:343-353.

Dollo, L. 1883. Première note sur les crocodiliens de Bernissart. Bulletin du Musée Royal D'Histoire Naturelle de Belgique 1883:309-340.

Farris, J., D. Källersjö, D. Lipscomb, \& A. G. Kluge. 1996. Parsimony jacknnifing outperform neighbor-joining. Cladistics 12:99-124.

Felsenstein, J. 1985. Confidence limits on phylogenies: an approach using the bootstrap. Evolution 39:783-791.

Fernandez, M., \& Z. Gasparini. 2000. Salt glands in a Tithonian metriorhynchid crocodyliform and their physiological significance. Lethaia 33:269-276.

Fernandez, M., \& Z. Gasparini. 2008. Salt glands in the Jurassic metriorhynchid Geosaurus: implications for the evolution of osmoregulation in Mesozoic marine crocodyliforms. Naturwissenschaften 95:79-84.

Fernandez, M., \& Y. Herrera. 2009. Paranasal sinus system of Geosaurus araucanensis and the homology of the antorbital fenestra of metriorhynchids (Thalattosuchia: Crocodylomorpha). Journal of Vertebrate Paleontology 29:702-714.

Figueiredo, R. G., J. K. R. Moreira, A. A. F. Saraiva, \& A. W. A. Kellner. 2011. Description of a new specimen of Susisuchus anatoceps (Crocodylomorpha: Mesoeucrocodylia) from the Crato 
Formation (Santana Group) with comments on Neosuchia. Zoological Journal of the Linnean Society 163:S273-S288.

Fiorelli, L. E., \& J. O. Calvo. 2007. The first "protosuchian" (Archosauria: Crocodyliformes) from the Cretaceous (Santonian) of Gondwana. Arquivos do Museu Nacional 65:417-459.

Fiorelli, L. E., \& J. O. Calvo. 2008. New remains of Notosuchus terrestris Woodward 1896 (Crocodyliformes: Mesoeucrocodylia) from Late Cretaceous Neuquèn, Patagonia, Argentina. Arquivos do Museu Nacional 66:83-124.

Fitzinger, L. J. F. J. 1843. Systema reptilium. Braumüller et Seidel, Wien, 136 pp.

Forey, P. L., \& I. J. Kitching. 2000. Experiments in coding multistate characters; pp. 54-80 in R. W. Scotland (ed.), Homology and systematics: coding characters for phylogenetic analysis. Taylor \& Francis, London.

Fortier, D., D. Perea, \& C. L. Schultz. 2011. Redescription and phylogenetic relationships of Meridiosaurus vallisparadisi, a pholidosaurid from the Late Jurassic of Uruguay. Zoological Journal of the Linnean Society 163:257-272.

Fraas, E. 1901. Die Meerkrokodile (Thalattosuchia n. g.) eine neue sauriergruppe der Juraformation. Jahreshefte des Vereins für vaterländische Naturkunde in Württemberg 57:409-418.

Gandole, R., E. Buffetaut, N. Monaghan, \& G. Dyke. 2006. Salt glands in the fossil crocodile Metriorhynchus. Journal of Vertebrate Paleontology 26:1009-1010.

Gasparini, Z. 1971. Los Notosuchia del Cretácico de América del Sur como un nuevo Infraorden de los Mesosuchia (Crocodilia). Ameghiniana 8:83-103.

Gasparini, Z. 1982: Una nueva familia de crocodrilos zifodontes Cretácicos de América del Sur. Vth Congreso Latinoamericano de Geología, Buenos Aires, 1982.

Gasparini, Z., \& E. Buffetaut. 1980. Dolichochampsa minima, n.g. n.sp., a representative of a new family of eusuchian crocodiles from the Late Cretaceous of northern Argentina. Neues Jahrbuch fur Geologie und Palaontologie, Monastshefte 5:257-271.

Gasparini, Z., L. M. Chiappe, \& M. Fernandez. 1991. A new Senonian peirosaurid (Crocodylomorpha) from Argentina and a synopsis of the South American Cretaceous crocodilian. Journal of Vertebrate Paleontology 11:316-333.

Gasparini, Z., M. Fernandez, \& J. Powell. 1993. New Tertiary sebecosuchians (Crocodylomorpha) from South America: phylogenetic implications. Hystorical Biology 7:1-19. 
Gasparini, Z., D. Pol, \& L. A. Spalletti. 2006. An unusual marine crocodyliform from the JurassicCretaceous boundary of Patagonia. Science 311:70-73.

Gauthier, J., A. G. Kluge, \& T. Rowe. 1988. Amniote phylogeny and the importance of fossils. Cladistics 4:105-209.

Goloboff, P., J. Farris, \& K. Nixon. 2008. TNT, a free program for phylogenetic analysis. Cladistics 24:774-786.

Gomani, E. M. 1997. A crocodyliform from the Early Cretaceous Dinosaur Beds, Northern Malawi. Journal of Vertebrate Paleontology 17:280-294.

Gow, C. E. 2000. The skull of Protosuchus haughtoni, an Early Jurassic crocodyliform fromSouthern Africa. Journal of Vertebrate Paleontology 20:49-56.

Hastings, A. K., J. I. Bloch, E. A. Cadena, \& C. A. Jaramillo. 2010. A new small short-snouted dyrosaurid (crocodylomorpha, Mesoeucrocodylia) from the paleocene of northeastern Colombia. Journal of Vertebrate Paleontology 30:139-162.

Hastings, A. K., J. I. Bloch, \& C. A. Jaramillo. 2011. A new longirostrine dyrosaurid (crocodylomorpha, mesoeucrocodylia) from the paleocene of north-eastern colombia: biogeographic and behavioural implications for new-world Dyrosauridae. Palaeontology 54:1095-1116.

Hecht, M. K., \& M. Archer. 1977. Presence of ziphondont crocodilians in the Tertiary and Pleistocene of Australia. Alcheringa 1:383-385.

Holliday, C. M., \& N. M. Gardner. 2012. A New Eusuchian Crocodyliform with Novel Cranial Integument and Its Significance for the Origin and Evolution of Crocodylia. Plos ONE $7: e 30471$.

Holmes, S. 2003. Bootstrapping phylogenetic trees: theory and methods. Statistical Science 18:241255.

Huxley, T. H. 1875. On Stagonolepis robertsoni, and on the evolution of the Crocodilia. Quarterly Journal of the Geological Society of London 31:423-438.

Iori, F. V., \& I. S. Carvalho. 2011. Caipirasuchus paulistanus, a new sphagesaurid (Crocodylomorpha, Mesoeucrocodylia) from the Adamantina Formation (Upper Cretaceous, Turonian-Santonian), Bauru Basin, Brazil. Journal of Vertebrate Paleontology 31:1255-1264. 
Iori, F. V., \& K. L. Garcia. 2012. Barreirosuchus franciscoi, um novo Crocodylomorpha Trematochampsidae da Bacia Bauru, Brasil. Revista Brasileira de Geociências 42:397-410.

Jouve, S. 2009. The Skull of Teleosaurus camodensis (Crocodylomorpha; Thalattosuchia), and Phylogenetic Analysis of Thalattosuchia. Journal of Vertebrate Paleontology 29:88-102.

Jouve, S. 2004. Etude des Crocodyliformes fini Crétacé-Paléogàne du Bassin des Oulad Abdoun (Maroc) et comparaison avec les faunes africaines contemporaines: systématique, phylogénie et paléobiogéographie. Muséum National d'Histoire Naturelle, Muséum National d'Histoire Naturelle, Paris, $651 \mathrm{pp}$.

Jouve, S., M. Iarochène, B. Bouya, \& M. Amaghzaz. 2005. A new dyrosaurid crocodyliform from the Palaeocene of Morocco and a phylogenetic analysis of Dyrosauridae. Acta Palaeontologica Polonica 50:581-594.

Jouve, S., M. Iarochène, B. Bouya, \& M. Amaghzaz. 2006. A new species of Dyrosaurus (Crocodylomorpha, Dyrosauridae) from the early Eocene of Morocco: phylogenetic implications. Zoological Journal of the Linnean Society 148:603-656.

Kälin, J. 1955. Zur Stammesgeschichte der Crocodilia. Revue Suisse De Zoologie 62:347-356.

Kearney, M. 2002. Fragmentary taxa, missing data, and ambiguity: mistaken assumptions and conclusions. Systematic Biology 51:369-381.

Kearney, M., \& J. M. Clark. 2003. Problems due to missing data in phylogenetic analyses including fossils: a critical review. Journal of Vertebrate Paleontology 23:263-274.

Kellner, A. W. A., D. A. Campos, \& L. I. Price. 1995: New material of Sphagesaurus (Sphagesauridae, Crocodylia) from the Late Cretaceous of Brazil. Atas do XIV Congresso Brasileiro de Paleontologia, 1995.

Kellner, A. W. A., \& D. A. Campos. 1999. Vertebrate paleontology in Brazil - a review. Episodes 22:238-251.

Kellner, A. W. A., A. C. A. Campos, D. Riff, \& M. B. Andrade. 2011a. A new crocodylomorph (Sphagesauridae, Notosuchia) with horn-like tubercles from Brazil. Zoological Journal of the Linnean Society 163:S57-S65.

Kley, N. J., J. J. W. Sertich, A. Turner, D. W. Krause, P. M. O'Connor, and J. A. Georgi. 2010. Craniofacial morphology of Simosuchus clarki (Crocodyliformes: Notosuchia) from the Late Cretaceous of Madagascar. Journal of Vertebrate Paleontology 30:13-98. 
Konzhukova, E. D. 1954. [New fossils crocodilians from Mongolia. Trudy Paleontologicheskogo Instituta ANSSSR 48:171-194.

Krause, D. W., J. J. W. Sertich, R. Rogers, S. C. Kast, A. H. Rasomiaramanana, and G. A. Buckley. 2010. Overview of the discovery, distribution, and geological context of Simosuchus clarki (Crocodyliformes: Nnotosuchia) from the late cretaceous of Madagascar. Journal of Vertebrate Paleontology 30:4-12.

Kuhn, O. 1968. Die Vorzeitlichen Krokodile. Oeben, Krailing, 124 pp.

Lapparent de Broin, F. 2002. Elosuchus, a new genus of crocodile from the Cretaceous of the North of Africa. Comptes Rendus Palevol 1:275-285.

Langston, W. 1973. The crocodilian skull in historical perspective; pp. 263-284 in C. Gans \& T. S. Parsons (eds.), Biology of Reptilia: Morphology D. Academic Press, London.

Langston, W. 1974. Nonmammalian Comanchean tetrapods. Geoscience and Man VIII:77-102.

Langston, J. W. 1956. The Sebecosuchia: Cosmopolitan crocodilians? American Journal of Science 254:605-614.

Larsson, H. C. E., \& B. Gado. 2000. A new Early Cretaceous crocodyliform from Niger. Neues Jahrbuch fur Geologie und Palaontologie, Abhandlungen 217:131-141.

Larsson, H. C. E., \& H.-D. Sues. 2007. Cranial osteology and phylogenetic relationships of Hamadasuchus rebouli (Crocodyliformes: Mesoeucrocodylia) from the Cretaceous of Morocco. Zoological Journal of the Linnean Society 149:533-567.

Larsson, H. C. E., T. Dececchi, \& F. C. Montefeltro. 2011: A new metriorhynchid (Crocodyliformes, Thalattosuchia) from the Early Cretaceous of Colombia (Rosablanco Formation, Late Valanginian). Resumos do: IV Congresso Latinoamericano de Paleontologia de Vertebrados, San Juan, Argentina, 2011.

Lauprasert, K., G. Cuny, E. Buffetaut, V. Suteethorn, \& K. Thirakhupt. 2007. Siamosuchus phuphokensis, a new goniopholidid from the Early Cretaceous (ante-Aptian) of northeastern Thailand. Bulletin de la Société Géologique de France 178:201-216.

Lauprasert, K., G. Cuny, K. Thirakhupt, \& V. Suteethorn. 2009. Khoratosuchus jintasakuli gen. et sp. nov., an advanced neosuchian crocodyliform from the Early Cretaceous (Aptian-Albian) of NE Thailand. Geological Society, London, Special Publications 315:175-187. 
Leardi, J. M., \& D. Pol. 2009. The first crocodyliform from the Chubut Group (Chubut Province, Argentina) and its phylogenetic position within basal Mesoeucrocodylia. Cretaceous Research 30:1376-1386.

Leardi, J. M., D. Pol, \& M. Fernandez. 2012. The antorbital fenestra of metriorhynchidae (Crocodyliformes, Thalattosuchia): testing its homology within a phylogenetic framework. Journal of Vertebrate Paleontology 32:490-494.

Lecuona, A., \& D. Pol. 2008. Tooth morphology of Notosuchus terrestris (Notosuchia: Mesoeucrocodylia): new evidence and implications. Comptes Rendus Palevol 7:407-417.

Lipscomb, D. 1992. Parsimony, homology and the analysis of multstate characters. Cladistics 8:45-65.

Lydekker, R. 1888. Part I., Catalogue of the fossil Reptilia and Amphibia in the British Museum (Natural History) British Museum (Natural History), London, 296-301 pp.

Maddison, W. P., \& D. R. Maddison. 2011. Mesquite: a modular system for evolutionary analysis. Version 2.75.

Maddison, W. P. 1993. Missing data versus missing characters in phylogenetic analysis. Systematic Biology 42:576-581.

Marinho, T. S., \& I. S. Carvalho. 2007. Revision of the Sphagesauridae Kuhn, 1968 (Crocodyliformes, Mesoeucrocodylia); pp. 581-592 in I. S. Carvalho (ed.), Paleontologia: Cenários da Vida. Editora Interciência.

Marinho, T. S., \& I. S. Carvalho. 2009. An armadillo-like sphagesaurid crocodyliform from the Late Cretaceous of Brazil. Journal of South American Earth Sciences 27:36-41.

Martin, J. E., M. Rabi, \& Z. Csiki. 2010. Survival of Theriosuchus (Mesoeucrocodylia: Atoposauridae) in a Late Cretaceous archipelago: a new species from the Maastrichtian of Romania. Naturwissenschaften 97:845-854.

Martinelli, A. G. 2003. New cranial remains of the bizarre notosuchid Comahuesuchus brachybuccalis (Archosauria, Crocodyliformes) from the late Cretaceous of Río Negro Province (Argentina). Ameghiniana 40:559-572.

Martinelli, A. G., J. J. W. Sertich, A. Garrido, \& A. M. Praderio. 2012. A new peirosaurid from the Upper Cretaceous of Argentina: Implications for specimens referred to Peirosaurus torminni Price (Crocodyliformes: Peirosauridae). Cretaceous Research 37:191-200. 
Mead, J. I., D. W. Steadman, S. H. Bedford, C. J. Bell, \& M. Spriggs. 2002. New extinct mekosuchine crocodile from Vanuatu, South Pacific. Copeia 2002:632-641.

Michard, J.-G., F. Broin, M. Brunet, \& J. Hell. 1990. Le plus ancien crocodilien néosuchien spécialisé à caracteres "eusuchiens" du continent africain (Crétacé inférieur, Cameroun). Comptes Rendus de l'Académie Des Sciences 311:365-371.

Montefeltro, F. C., \& H. C. E. Larsson. 2011. Evolution of the otic region of fossil Crocodyliformes. Journal of Vertebrate Paleontology 2-5:161-161.

Montefeltro, F. C., \& H. C. E. Larsson. 2012: O ouvido externo dos Crocodyliformes fósseis. VIII Simpósio Brasileiro de Paleontologia de Vertebrados, Recife, Brazil, 2012.

Montefeltro, F. C. 2009. Multicusped crocodyliform teeth from the Upper Cretaceous (São José do Rio Preto Formation, Bauru Group) of São Paulo, Brazil. Cretaceous Research 30:1279-1286.

Montefeltro, F. C., H. C. E. Larsson, \& M. C. Langer. 2011. A New Baurusuchid (Crocodyliformes, Mesoeucrocodylia) from the Late Cretaceous of Brazil and the Phylogeny of Baurusuchidae. Plos ONE 6:e21916.

Mueller-Töwe. 2005. Phylogenetic relationships of the Thalattosuchia. Zitteliana A45:211-213.

Mueller-Töwe. 2006. Anatomy, phylogeny, and palaeoecology of the basal thalattosuchians (Mesoeucrocodylia) from the Liassic of Central Europe. Chemie, Pharmazie und Geowissenschaften, Johannes Gutenberg-Universität, Mainz, 422 pp.

Nascimento, P. M., \& H. Zaher. 2011. The skull of the Upper Cretaceous baurusuchid crocodile Baurusuchus albertoi Nascimento \& Zaher 2010, and its phylogenetic affinities. Zoological Journal of the Linnean Society 163:S116-S131.

Nesbitt, S. 2011. The eary evolution of archosaurs: relationships and the origin of major clades. Bulletin of American Museum of Natural History 352:1-352.

Nixon, K. C., \& J. M. Carpenter. 1993. On outgroups. Cladistics 9:413-426.

Nixon, K., \& Q. D. Wheeler. 2003. Extinction and the origin of species.; pp. 119-143 in M. J. Novacek and Q. D. Wheeler (eds.), Extinction and Phylogeny. Columbia University Press, New York.

Norell, M. A. 1988. Cladistic approaches to paleobiology as applied to the phylogeny of alligatorids. Yale University, New Haven, Connecticut, 544 pp. 
Norell, M. A., \& J. M. Clark. 1990. A reanalysis of Bernissartia fagesii, with comments on its phylogenetic position and its bearing on the origin and Diagnosis of the Eusuchia. Bulletin de L'Institut Royal des Sciences Naturelles de Belgique 60:115-128.

Norell, M. A., \& W. C. Wheeler. 2003. Missing entry replacement data analysis: a replacement approach to dealing with missing data in paleontological and total evidence data sets. Journal of Vertebrate Paleontology 23:275-283.

Novas, F., D. F. Pais, D. Pol, A. B. Carvalho, A. Scanfalera, A. Mones, \& M. S. Riglos. 2009. Bizarre Notosuchian crocodyliform with associated eggs from the Upper Cretaceous of Bolivia. Journal of Vertebrate Paleontology 29:1316-1320.

O'Connor, P. M., J. J. W. Sertich, N. J. Stevens, E. M. Roberts, M. D. Gottfried, T. L. Hieronymus, Z. A. Jinnah, R. Ridgely, S. E. Ngasala, \& J. Tembra. 2010. The evolution of mammal-like crocodyliforms in the Cretaceous Period of Gondwana. Nature 466:748-751.

Ortega, F., \& A. D. Buscalioni. 1995. Las hoyas crocodiles, an evidence of the transition model of the eusuchian dorsal armour configuration; pp. 53-56 in II International Symposium on Lithographic Limestones, Ediciones de la Universidad Autónoma de Madrid, Lleida-Cuenca.

Ortega, F. 2004. Historia evolutiva de los cocodrilos Mesoeucrocodylia. Universidad Autónoma de Madrid, Madrid, $350 \mathrm{pp}$.

Ortega, F., A. D. Buscalioni, \& Z. Gasparini. 1996. Reinterpretation and new denomination of Atacisaurus crassiporatus (Middle Eocene; Issel, France) as cf. Iberosuchus (Crocodylomorpha, Metasuchia). Géobios 29:353-364.

Ortega, F., Z. Gasparini, A. D. Buscalioni, \& J. O. Calvo. 2000. A new species of Araripesuchus (Crocodylomorpha, Mesoeucrocodylia) from the lower Cretaceous of Patagonia (Argentina). Journal of Vertebrate Paleontology 20:57-76.

Ösi, A. 2008. Cranial osteology of Iharkutosuchus makadii, a Late Cretaceous basal eusuchian crocodyliform from Hungary. Neues Jahrbuch fur Geologie und Palaontologie, Abhandlungen 248:279-299.

Ősi, A., J. M. Clark, \& D. B. Weishampel. 2007. First report on a new basal eusuchian crocodyliform with multicusped teeth from the Upper Cretaceous (Santonian) from Hungary. Neues Jahrbuch fur Geologie und Palaontologie, Abhandlungen 243:169-177. 
Osmólska, H., S. Hua, \& E. Buffetaut. 1997. gobiosuchus Kielanae (Protosuchia) from the Late Cretaceous of Mongolia: anatomy and relationships. Acta Palaeontologica Polonica 42:257289.

Paolillo, A., \& O. J. Linares. 2007. Nuevos cocodrilos Sebecosuchia del cenozoico suramericano (Mesosuchia: Croodylia). Pelobiologia Neotropical 3:1-25.

Pierce, S. E., K. D. Angielczyk, \& E. J. Rayfield. 2009. Morphospace occupation in Thalattosuchian crocodylomorphs: skull Shape variation, species delineation and temporal patterns. Palaeontology 52:1057-1097.

Pierce, S. E., K. D. Angielczyk, \& E. J. Rayfield. 2008. Patterns of morphospace occupation and mechanical performance in extant crocodilian skulls: a combined geometric morphometric and finite element modeling approach. Journal of Morphology 269:840-864.

Platnick, N. I., C. E. Griswold, \& J. Coddington. 1991. On missing entries in cladistic analysis. Cladistics 7:337-343.

Pol, D. 1999. El esqueleto postcraneano de Notosuchus terrestris (Archosauria: Crocodyliformes) del Cretácico Superior de la Cuenca Neuquina y su información fi logenética. Universidad de Buenos Aires, Buenos Aires, 158 pp.

Pol, D. 2003. New remains of Sphagesaurus huenei (Crocodylomorpha: Mesoeucrocodylia) from the Late Cretaceous of Brazil. Journal of Vertebrate Paleontology 23:817-831.

Pol, D., \& S. Apesteguia. 2005. New Araripesuchus remains from the Early Late Cretaceous (Cenomanian-Turonian) of Patagonia. American Museum Novitates 3490:1-38.

Pol, D., \& H. Escapa. 2009. Unstable taxa in cladistic analysis: identification and the assessment of relevant characters. Cladistics 25:515-527.

Pol, D., \& Z. Gasparini. 2009. Skull anatomy of Dakosaurus andiniensis (Thalattosuchia: Crocodylomorpha) and the phylogenetic position of Thalattosuchia. Journal of Systematic Palaeontology 7:163-197.

Pol, D., \& H. C. E. Larsson. 2011. 1st Symposium on the evolution of crocodyliforms. Zoological Journal of the Linnean Society 163:S1-S6.

Pol, D., \& M. A. Norell. 2004a. A new crocodyliform from Zos Canyon, Mongolia. American Museum Novitates 3445:1-36. 
Pol, D., \& M. A. Norell. 2004b. A new Gobiosuchid Crocodyliform taxon from the Cretaceous of Mongolia. American Museum Novitates 3458:1-31.

Pol, D., \& J. Powell. 2011. A new sebecid mesoeucrocodylian from the Rio Loro Formation (Palaeocene) of north-western Argentina. Zoological Journal of the Linnean Society 163.

Pol, D., S.-a. Ji, J. M. Clark, \& L. M. Chiappe. 2004. Basal crocodyliforms from the Lower Cretaceous Tugulu Group (Xinjiang, China) and the phylogenetic position of Edentosuchus. Cretaceous Research 25:603-622.

Pol, D., A. Turner, \& M. A. Norell. 2009. Morphology of the Late Cretaceous crocodylomorph Shamosuchus djachtaensis and a discussion of neosuchian phylogeny as related to the origin of Eusuchia. Bulletin of American Museum of Natural History 324:1-103.

Pol, D., J. M. Leardi, A. Lecuona, \& D. W. Krause. 2012. Postcranial anatomy of Sebecus icaeorhinus (Crocodyliformes, Sebecidae) from the Eocene of Patagonia. Journal of Vertebrate Paleontology 32:328-354.

Prasad, G. V. R., \& F. Lapparent de Broin. 2002. Late Cretaceous crocodile remains from Naskal (India): comparisons and biogeographic affinities. Annales de Paléontologie 82:19-71.

Prevosti, F., \& M. A. Chemisquy. 2010. The impact of missing data on real morphological phylogenies: influence of the number and distribution of missing entries. Cladistics 26:326339.

Price, L. I. 1945. A new reptil from the Cretaceous of Brazil. Notas Preliminares e Estudos - Divisão de Geologia e Mineralogia, Rio de Janeiro - Brasil 25:1-8.

Price, L. I. 1950. On a new Crocodilian, Sphagesaurus, from the Cretaceous of the state of São Paulo, Brazil. Anais da Academia Brasileira de Ciências XXII:77-85.

Price, L. I. 1955. Novos Crocodilídeos dos Arenitos da Série Baurú, Cretáceo do Estado de Minas Gerais. Divisão de Geologia e Mineralogia do Departamento Nacional da Produção Mineral, Rio de Janeiro, D. F. 27:487-498.

Price, L. I. 1959. Sobre um crocodilídeo notossúquio do Cretácico brasileiro. Boletin da Divisão de Geologia e Mineralogia, Departamento Nacional da Produção Mineral 188:1-55.

Rasmusson, E. L. 2008. New material of Trematochampsa oblita (Crocodyliformes, Trematochampsidae) from the Late Cretaceous of Madagascar, with a review and cladistic analysis of the Family Trematochampsidae. Department of Geological Sciences, Michigan State University, 75 pp. 
Riff, D., \& A. W. A. Kellner. 2011. Baurusuchid crocodyliforms as theropod mimics: clues from the skull and appendicular morphology of Stratiotosuchus maxhechti (Upper Cretaceous of Brazil). Zoological Journal of the Linnean Society 163:S37-S56.

Rogers II, J. V. 2003. Pachycheilosuchus trinquei, a new procoelous crocodyliform from the Lower Cretaceous (Albian) Glen Rose Formation of Texas. Journal of Vertebrate Paleontology 23:128-145.

Rossmann, T. 2000. Studies on Cenozoic crocodiles: 5. Biomechanical Investigation on the postcranial skeleton of the Palaeogene crocodile Pristichampsus rollinati (Eusuchia: Pristichampsidae). Neues Jahrbuch fur Geologie und Palaontologie, Abhandlungen 217:829-300.

Rossmann, T., M. Rauhe, \& F. Ortega. 2000. Studies on Cenozoic crocodiles 8. Description of Bergisuchus dietrichbergi Kühn (Sebecosuchia: Bergisuchidae n. fam.) from the Middle Eocene of Germany, and some new systematic and biological conclusions. Paläontologische Zeitschrift 74:379-392.

Rusconi, C. 1933. Sobre reptiles cretáceos del Uruguay (Uruguaysuchus aznarezi, n. g. n. Sp.) y sus relaciones com los notossuquidos de Patagonia. Boletin del Instituto de Geologia y perforaciones Montevideo Uruguay 19:1-69.

Salisbury, S. W., R. Molnar, E. Frey, \& P. M. A. Willis. 2006. The origin of modern crocodyliforms: new evidence from the Cretaceous of Australia. Proceedings of the Royal Society of London B 273:2439-2448.

Salisbury, S. W., \& D. Naish. 2011. Crocodilians; pp. 305-369 in D. J. Batten (ed.), english Wealden fossils. The Palaeontological Association, London.

Sereno, P. C. 2007. Logical basis for morphological characters in phylogenetics. Cladistics 11:309315.

Sereno, P. C., \& H. C. E. Larsson. 2009. Cretaceous Crocodyliforms from the Sahara. Zookeys 28:1143.

Sereno, P. C., H. C. E. Larsson, C. A. Sidor, \& B. Gado. 2001. The giant Crocodyliform Sarcosuchus from the Cretaceous of Africa. Science 294:1516-1519.

Sereno, P. C., C. A. Sidor, H. C. E. Larsson, \& B. Gado. 2003. A new Notosuchian from the early Cretaceous of Niger. Journal of Vertebrate Paleontology 23:477-482. 
Sertich, J. J. W., \& P. M. O'Connor. 2010. The evolution of trematochampsid crocodyliforms in Africa: new evidence from the Middle Cretaceous Galula Formation, Southwestern Tanzania. Journal of Vertebrate Paleontology 30:163.

Sertich, J. J. W. 2011. New remains of Miadanasuchus oblita the Late Cretaceous of Madagascar a reevaluation of Trematochampsidae. Journal of Vertebrate Paleontology 31:193.

Simons, E. L. R., \& G. A. Buckley. 2009. New material of "Trematochampsa" oblita (Crocodyliformes Trematochampsidae) from the Late Cretaceous of Madagascar. Journal of Vertebrate Paleontology 29:599-604.

Simpson, G. G. 1937. New reptiles from the eocene of South America. American Museum Novitates 927:1-3.

Smith, D. K., E. R. Allen, R. K. Sanders, \& K. L. Stadtman. 2010. A new specimen of Eutretauranosuchus (Crocodyliformes; Goniopholididae) from Dry Mesa, Colorado. Journal of Vertebrate Paleontology 30:1466-1477.

Soto, M., D. Pol, \& D. Perea. 2011. A new specimen of Uruguaysuchus aznarezi (Crocodyliformes: Notosuchia) from the middle Cretaceous of Uruguay and its phylogenetic relationships. Zoological Journal of the Linnean Society 163:S173-S198.

Steel, R. 1973. Crocodylia; in O. Kuhn (ed.), Handbuch der Paläoherpetologie/Encyclopedia of Paleoherprtology, Volume 16. Gustav Fischer Verlag, Stuttgart - Portland.

Stefano, G. de 1903. Nuovi rettili degli strati a fosfato della Tunisia. Bolletino dela Societa Geologia Italiana 22:51-80.

Stromer, E. 1925. Ergebnisse der Forschungsreisen Prof. E. Stromers in den Wüsten Ägyptens. II. Wirbeltier-Reste der Baharije-Stufe (unterstes Cenoman). 7 Stomatosuchus inermis Stromer, ein schwach bezahnter Krokodilier und 8. Ein Skelettrest des Pristiden Onchopristis numidus Huag sp. Abhandlungen der Bayerischen Akademie der Wissenschaften. Mathematischnaturwissenschaftliche Abteilung 30:1-22.

Stromer, E. 1936. Ergebnisse der Forschungsreisen Prof. E. Stromers in den Wüsten Ägyptens. II. Wirbeltier-Reste der Baharije-Stufe (unterstes Cenoman). VII. Baharije-Kessel und -Stufe mit deren Fauna und Flora. Eine ergänzende Zusammenfassung. Abhandlungen der Königlich Bayerischen Akademie der Wissenschaften. Mathematisch-naturwissenschaftliche Abteilung 33:1-102.

Strong, E. E., \& D. Lipscomb. 1999. Character coding and inapplicable data. Cladistics 23:565-587. 
Sues, H.-D., P. E. Olsen, J. G. Carter, \& D. M. Scott. 2003. A new crocodylomorph archosaur from the Upper Triassic of North Carolina. Journal of Vertebrate Paleontology 23:329-343.

Sues, H.-D., J. M. Clark, \& F. Jenkins Jr. 1994. A review of the Early Jurassic tetrapods from the Glen Canyon Group of the American southwest; pp. 284-294 in N. C. Fraser and H.-D. Sues (eds.), In the shadows of dinosaurs: early Mesozoic tetrapods. Cambridge University Press, Cambridge.

Turner, A. 2004. Crocodyliform biogeography during the Cretaceous: biogeographical analysis. Proceedings of the Royal Society of London B 271:2003-2009.

Turner, A. 2006. Osteology \& phylogeny of a new species of Araripesuchus (Crocodyliformes: Mesoeucrocodylia) from the Late Cretaceous of Madagascar. Hystorical Biology 18:255-369.

Turner, A., \& J. O. Calvo. 2005. A new sebecosuchian crocodyliform from the Late Cretaceous of Patagonia. Journal of Vertebrate Paleontology 25:87-98.

Turner, A., \& G. A. Buckley. 2008. Mahajangasuchus insignis (Crocodyliformes: Mesoeucrocodylia) cranial anatomy and new data on the origin of the eusuchian-style palate. Journal of Vertebrate Paleontology 28:382-408.

Turner, A., \& J. J. W. Sertich. 2010. Phylogenetic history of Simosuchus clarki (Crocodyliformes: Notosuchia) from the Late Cretaceous of Madagascar. Journal of Vertebrate Paleontology Memoir 30:177-236.

Turner, A., \& C. A. Brochu. 2011. Neosuchian phylogeny and a reevaluation of the crocodyliform Shamosuchus from the Cretaceous of Asia. Ameghiniana 48:94-95.

Tykosky, R. S., T. B. Rowe, R. A. Ketcham, \& M. W. Colbert. 2002. Calsoyasuchus valliceps, a new Crocodyliform from the early Jurassic Kayenta Formation of Arizona. Journal of Vertebrate Paleontology 22:593-611.

Vasconcellos, F. M., \& I. S. Carvalho. 2010. Paleoichnological assemblage associated with Baurusuchus salgadoensis remains, a Baurusuchidae Mesoeucrocodylia from the Bauru Basin, Brazil (Late Cretaceous). New Mexico Museum of Natural History and Science, Bulletin $51: 227-237$.

Wenzel, J. J., \& M. E. Siddall. 1999. Noise. Cladistics 15:51-64.

Whetstone, K. N., \& P. Whybrow. 1983. A Cursorial Crocodilian from the Triassic of Lesotho (Basutiland, South Africa). Occasional Papers of the Museum of Natural History, University Kansas 106:1-37. 
Wiens, J. J. 2003. Incomplete taxa, incomplete characters and phylogenetic accuracy: is there a missing data problem? Journal of Vertebrate Paleontology 23:297-310.

Wiens, J. J. 2005. Can incomplete taxa rescue phylogenetic analyses from long-branch attraction? Systematic Biology 54:731-742.

Wilkinson, M. 1995. Coping with abundant missing entries in phylogenetic inference using parsimony. Systematic Biology 44:501-514.

Wilkinson, M. 2003. Missing entries and multiple trees: instability, relashionships, and support in parsimony analysis. Journal of Vertebrate Paleontology 23:311-323.

Wilkinson, M., \& M. Benton. 1995. Missing data and rhynchosaur phylogeny. Hystorical Biology 10:137-150.

Wilkinson, L. E., M. T. Young, \& M. J. Benton. 2008. A new metriorhynchid crocodilian (Mesoeucrocodylia: Thalattosuchia) from the Kimmeridgian (Upper Jurassic) of Wiltshire, UK. Palaeontology 51:1307-1333.

Wilson, J. A., M. S. Malkani, \& P. D. Gingerich. 2001. New crocodyliform (Reptilia, Mesoeucrocodylia) from the Upper Cretaceous Pab Formation of Vitakri, Balochistan (Pakistan). Contributions from the Museum of Paleontology, University of Michigan 30:321336.

Witmer, L. M. 1997. The evolution of the antorbital cavity of archosaurus: a study in soft-tissue reconstruction in the foissl record with analysis of the function of pneumaticity. Journal of Vertebrate Paleontology 17:1-76.

Woodward, A. S. 1896. On two Mesozoic crocodilians, Notosuchus (genus novum) and Cynodontosuchus (genus novum) from the red sandstones of the territory of Neuquén (Argentina). Anales Museo de La Plata 4:1-20.

Wu, X.-C., \& D. B. Brinkman. 1993. A new crocodylomorph of "mesosuchian" grade from the Upper Cretaceous Milk River Formation, Southern Alberta. Journal of Vertebrate Paleontology 13:153-160.

Wu, X.-C., \& S. Chatterjee. 1993. Dibothrosuchus elaphros, a crocodylomorph from the Lower Jurassic of China and the Phylogeny of the Sphenosuchia. Journal of Vertebrate Paleontology 13:58-89. 
Wu, X.-C., \& H.-D. Sues. 1996. Anatomy and phylogenetic relationships of Chimaerasuchus paradoxus, an unusual crocodyliform reptile from the Lower Cretaceous of Hubei, China. Journal of Vertebrate Paleontology 16:688-702.

Wu, X.-C., D. B. Brinkman, \& J.-C. Lu. 1994a. A new species of Shantungosuchus from the Lower Cretaceous of Inner Mongolia (China), with comments on S. chuhsienensis Young, 1961 and the phylogenetic position of the genus. Journal of Vertebrate Paleontology 14:210-229.

Wu, X.-C., J. Li, \& X. Li. 1994. Phylogenetic relationship of Hsisosuchus. Vertebrata Palasiatica 7:166-180.

Wu, X.-C., H.-D. Sues, \& A. Sun. 1995. A plant-eating crocodyliform reptile from the Cretaceous of China. Nature 376:678-680.

Wu, X.-C., H.-D. Sues, \& Z.-M. Dong. 1997. Sichuanosuchus shuhanensis, a new ?Early Cretaceous protosuchian (Archosauria: Crocodyliformes) from Sichuan (China), and the monophyly of Protosuchia. Journal of Vertebrate Paleontology 17:89-103.

Young, M. T., \& M. B. Andrade. 2009. What is Geosaurus? Redescription of Geosaurus giganteus (Thalattosuchia: Metriorhynchidae) from the Upper Jurassic of Bayern, Germany. Zoological Journal of the Linnean Society 157:551-585.

Young, C. C. 1973. A new fossil crocodile from Wuerho. Memoirs of the Institute of Vertebrate Paleontology and Paleoanthropology, Academia Sinica 11:37-44.

Young, M. T., S. L. Brussatte, M. Ruta, \& M. B. Andrade. 2010. The evolution of Metriorhynchoidea (Mesoeucrocodylia, Thalattosuchia): an integrated approach using geometric morphometrics, analysis of disparity, and biomechanics. Zoological Journal of the Linnean Society 158:801859.

Young, M. T., M. B. Andrade, \& S. L. Brussatte. 2011a. Body size estimation and evolution in metriorhynchid crocodylomorphs: implications for species diversification and niche partitioning. Zoological Journal of the Linnean Society 163:1199-1216.

Young, M. T., M. A. Bell, \& S. L. Brussatte. 2011b. Craniofacial form and function in Metriorhynchidae (Crocodylomorpha: Thalattosuchia): modelling phenotypic evolution with maximum likelihood methods. Biology Letters 7:913-916.

Young, M. T., S. L. Brussatte, M. B. Andrade, J. B. Desojo, B. L. Beatty, L. Steel, M. Fernandez, M. Sakamoto, Ruiz-Omeñaca, \& R. M. Schoch. 2012. The cranial osteology and feeding ecology 
of the metriorhynchid crocodylomorph genera Dakosaurus and Plesiosuchus from the Late Jurassic of Europe. Plos ONE 7:1-42.

Zaher, H., D. Pol, A. B. Carvalho, C. Riccomini, D. A. Campos, \& W. R. Nava. 2006. Redescription of the cranial morphology of Mariliasuchus amarali, and Its phylogenetic affinities (Crocodyliformes, Notosuchia). American Museum Novitates 3512:1-40.

Zittel, K. A. v., \& C. R. Eastman. 1902. Text-book of palaeontology. Macmillan, London. 


\section{APÊNDICES}

\section{APÊNDICE I. TÁXONS TERMINAIS}

Os táxons terminais da análise filogenética são listados abaixo discriminando as fontes de informação utilizadas para suas codificações. As publicações utilizadas são referidas, e os números dos espécimes são fornecidos quando o material foi analisado pessoalmente (p) ou por fotos (f), vide acrômios institucionais ao final de lista de táxons. Para táxons supraespecíficos são listadas as espécies circunscritas na codificação. Holótipos, parátipos e lectótipos são sublinhados. Os táxons são listados e suas codificações explicitadas na matriz (ver Materiais e Métodos, III.III e Matriz, apêndice III).

\section{Táxons do grupo externo}

\section{“Crocodylomorpha não Crocodyliformes"}

Dibothrosuchus elaphros - Wu \& Chatterjee (1993), Clark \& Sues (2002), Clark et al. (2004).

Litargosuchus leptorhynchus - Gow \& Kitching (1988), Clark \& Sues (2002); BP/1/5237 P

(p).

Sphenosuchus acutus - Haughton (1915), Walker (1990), Clark \& Sues (2002), Clark et al.

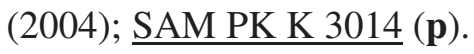

\section{“Crocodyliformes não Mesoeucrocodylia"}

Fruitachampsa callisoni - Turner \& Sertich (2010), Clark (2011), Pol et al. (2012). 
Gobiosuchus kielanae - Osmólska (1972), Osmólska et al. (1997), Turner \& Sertich (2010),

Pol et al. (2012).

Hemiprotosuchus leali - Bonaparte (1971); Turner \& Sertich (2010), Pol et al. (2012); PVL $\underline{3829}(\mathbf{f})$.

Hsisosuchus - Hsisosuchus chowi, Hsisosuchus dashanpuensis e Hsisosuchus chungkingen;

Li et al. (1994), Gao (2001), Peng \& Shu (2005), Andrade et al. (2011), Turner \& Sertich (2010), Pol et al. (2012).

Orthosuchus strombergi - Nash (1968), Nash (1975), Benton \& Clark (1988); Sereno \& Larsson (2009), Nesbitt (2011), Pol et al. (2012); $\underline{\text { SAM PK K } 4639}$ (p), BP/1/4770 (p).

Protosuchus haughtoni - Busbey \& Gow (1984), Gow (2000), Nesbitt (2011); BP/1/4746 (p), BP/1/4946 (p), BP/1/590 (p), BP/1/4770 (p), SAM PK K 8026 (p).

Protosuchus richardsoni - Brown (1933), Hetch \& Tarsitano (1983), Sereno \& Larsson (2009), Turner \& Sertich (2010), Nesbitt (2011), Pol et al. (2012); $\underline{\text { AMNH FR } 3016}$ (p).

Shantungosuchus - Shantungosuchus hangjinensis e Shantungosuchus brachycephalus; Wu et al. (1994a), Lu \& Wu (1996), Turner \& Sertich (2010), Pol et al. (2012).

Sichuanosuchus - Sichuanosuchus shuhanensis e Sichuanosuchus huidongensis; Wu et al. (1997), Peng (1996), Turner \& Sertich (2010), Pol et al. (2012).

Zosuchus davidisoni - Pol \& Norell (2004a), Sereno \& Larsson (2009), Turner \& Sertich (2010), Pol et al. (2004). 


\section{Táxons do grupo interno (Mesoeucrocodylia)}

Adamantinasuchus navae - Nobre \& Carvalho (2006), Turner \& Sertich (2010), Andrade et al. (2011); UFRJ-DG 107-R (p).

Anatosuchus minor - Sereno et al. (2003), Sereno \& Larsson (2009), Turner \& Sertich (2010), Andrade et al. (2011), Pol et al. (2012); MNN GAD 17 (p), MNN GAD 18 (p), $\underline{\text { MNN GAD } 603}$ (p).

Araripesuchus buitreaensis - Pol \& Apesteguia (2005), Turner (2006), Sereno \& Larsson (2009), Turner \& Sertich (2010), Andrade et al. (2011), Pol et al. (2012).

Araripesuchus cf. Niger - MNN GAD 283 (p).

Araripesuchus gomesi - Price (1959), Hetch (1991), Ortega et al. (2000), Pol \& Apesteguia (2005), Turner (2006), Sereno \& Larsson (2009), Turner \& Sertich (2010), Andrade et al. (2011), Pol et al. (2012); AMNH 24450 (p).

Araripesuchus patagonicus - Ortega et al. (2000), Pol \& Apesteguia (2005), Turner (2006), Sereno \& Larsson (2009), Turner \& Sertich (2010), Andrade et al. (2011), Pol et al. (2012); MUCPv 267 (p), MUCPv 268 (p), $\underline{\operatorname{MUCPv} 269}$ (p).

Araripesuchus rattoides - Sereno \& Larsson (2009); CMN 41893 (p), UCRC PV3 (p), ROM $64711(\mathbf{p})$.

Araripesuchus tsangatsangana - Turner (2006), Sereno \& Larsson (2009), Turner \& Sertich (2010), Andrade et al. (2011), Pol et al. (2012).

Araripesuchus wegneri - Sereno \& Larsson (2009); MNN GAD19 (p), MNN GAD 20 (p), MNN GAD 23 (p), MNN GAD 26 (p). 
Armadillosuchus arrudai - Marinho \& Carvalho (2009), Turner \& Sertich (2010),

Montefeltro et al. (2011), Andrade et al. (2011); UFRJ DG 303-R (p), MPMA 640001/04 (p).

Ayllusuchus fernandezi - Gasparini (1984), Pol \& Powell (2011), Pol et al. (2012); MLP 72$\underline{\mathrm{X}-4-2}(\mathbf{p})$.

Barinasuchus arveloi - Paolillo \& Linares (2008), Pol \& Powell (2011), Pol et al. (2012).

Barreirosuchus fransciscoi - Iori \& Garcia (2012).

Baurusuchus albertoi - Nascimento \& Zaher (2010, 2011), Montefeltro et al. (2011); MZSP$\underline{\text { PV } 140}(\mathbf{p})$.

Baurusuchus pachecoi - Price (1945), Benton \& Clark (1988), Riff \& Kellner (2001), Carvalho et al. (2005), Pol \& Gasparini (2007), Nascimento \& Zaher (2010, 2011), Montefeltro et al. (2011), Pol \& Powell (2011); DGM 299-R (f).

Baurusuchus salgadoensis - Carvalho et al. (2005), Nascimento \& Zaher (2010, 2011), Montefeltro et al. (2011), Pol \& Powell (2011); MPMA 62-0001-02 (p).

Bergisuchus dietrichbergi - Rossman et al. (2000), Pol \& Powell (2011), Andrade et al. (2011), Pol et al. (2012); Me 7003 HLD (p).

Bretesuchus bonapartei - Gasparini et al. (1993); Pol \& Powell (2011), Pol et al. (2012); PVL $\underline{4735}(\mathbf{f})$.

Caipirasuchus paulistanus - Iori \& Carvalho (2011); MPMA 67-00001/00 (p).

Campinasuchus dinizi - Carvalho et al. (2011). 
Candidodon itapecuruensis - Carvalho \& Campos (1988), Carvalho (1994), Nobre \&

Carvalho (2002), Nobre (2004), Montefeltro et al. (2009), Andrade et al. (2006); $\underline{\mathrm{MN}}$ 4154 (f), UFRJ 113R (p), UFRJ 114R (p).

Caryonosuchus pricei - Kellner et al. (2011a); DGM 1411-R (p).

Chimaerasuchus paradoxus - Wu et al. (1995), Wu \& Sues (1996), Jouve (2009), Turner \& Sertich (2010), Pol et al (2012).

Comahuesuchus brachybuccalis - Martinelli (2003), Turner \& Sertich (2010), Andrade et al. (2011), Pol et al. (2012); MACN-PV 31 (p), MUCP-PV 202 (p), MOZ 6131 (p).

Cricosaurus araucanensis - Gasparini \& Dellape (1976), Fernández \& Gasparini (2000, 2008), Pol \& Gasparini (2009), Young \& Andrade (2009), Herrera et al. (2009), Young et al. (2010, 2011); MACN-N 95 (f).

Cricosaurus Colômbia - Larsson et al. (2011); RM sem número (p).

Cricosaurus schroederi - Karl et al. (2006), Young \& Andrade (2009), Young et al. (2010, 2011).

Cricosaurus suevicus - Young \& Andrade (2009), Young et al. (2010, 2011), Andrade et al. (2011), Pol et al. (2012).

Cricosaurus vignaudi - Frey et al. (2002), Young \& Andrade (2009), Young et al. (2010, 2011).

Cynodontosuchus rothi - Pol \& Gasparini (2007), Montefeltro et al. (2011); MLP 64-IV-16$\underline{25}(\mathbf{p})$.

Dakosaurus andiniensis - Gasparini et al. (2006), Pol \& Gasparini (2009), Pol et al. (2012), Young et al. (2012); MOZ 6146P (p). 
Doratodon carcharidens - Bunzel (1871), Seeley (1881), Buffetaut (1979); IPUW 234952

(p), IPUW 234953 (p), IPUW 234955a-b (p), IPUW 234957 (p), IPUW 234958 (p), IPUW 234959 (p), IPUW 234960 (p), IPUW 234961 (p).

Doratodon ibericus - Company et al. (2005); LPRP/USP réplica sem número (p).

Eremosuchus elkoholicus - Buffetaut (1982b, 1989), Turner \& Calvo (2005).

Forma de Ingall - MNN GDF T221 (p).

Forma de Itaboraí - Gasparini (1984), Company et al. (2005), Pinheiro et al. (2011).

Gasparinisuchus peirosauroides - Gasparini (1982), Gasparini et al. (1991), Martinelli et al. (2012); $\underline{\mathrm{MOZ}} 1750$ (p).

Hamadasuchus rebouli - Larsson \& Sues (2007), Sereno \& Larsson (2009), Andrade et al. (2011); ROM 4982 (p), ROM 52059 (p), ROM 52620 (p), ROM 54511 (p).

Iberosuchus macrodon - Antunes (1975); SGP 5679 (p).

Itasuchus jesuinoi - Price (1955), Vasconcellos (2006); DGM 434-R (p).

Kaprosuchus saharicus - Sereno \& Larsson (2009), Turner \& Sertich (2010), Andrade et al.

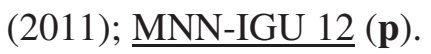

Labidiosuchus amicum - Kellner et al. (2011b).

Libycosuchus brevirostris - Turner \& Sertich (2010), Andrade et al. (2011), Pol et al. (2012).

Lomasuchus palpebrosus - Gasparini et al. (1991), Turner \& Sertich (2010), Pol \& Powell

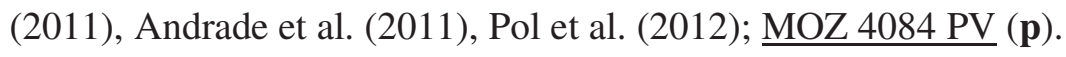

Lorosuchus nodosus - Pol \& Powell (2011), Pol et al. (2012). 
Mahajangasuchus insignis - Buckley \& Brochu (1999), Turner \& Buckley (2008), Sereno \& Larsson (2009), Turner \& Sertich (2010), Andrade et al. (2011), Pol et al. (2012).

Malawisuchus mwakasyungutiensis - Clark et al. (1989), Gomani (1997), Turner \& Sertich (2010), Andrade et al. (2011), Pol et al. (2012).

Mariliasuchus amarali - Carvalho \& Bertini (1999), Zaher et al. (2006), Andrade et al. (2008b), Montefeltro et al. (2011), Pol et al. (2012); UFRJ-D-50-R (p), UFRJ-D105-R (p), UFRJ-D-106-R (p).

Mariliasuchus robustus - Nobre et al. (2007); UFRJ-D-56-R (p).

Metriorhynchidae Áustria - IPUW sem número.

Metriorhynchus casamiquelai - Gasparini \& Díaz (1977), Pol \& Gasparini (2007), Young \& Andrade (2009), Young et al. (2010, 2011).

Metriorhynchus superciliosum - Young \& Andrade (2009), Young et al. (2010, 2011); AMNH FR 997 (p).

Miadanasuchus oblita - Buffetaut \& Taquet (1979), Rasmusson (2008), Simons \& Buckley (2009).

Montealtosuchus arrudacamposi - Carvalho et al. (2007), Andrade et al. (2011); MPMA-16$\underline{007-04}(\mathbf{p})$.

Morrinhosuchus luziae - Iori \& Carvalho (2009); MPMA 07-0009/01 (p).

Notosuchus terrestris - Fiorelli \& Calvo (2008), Andrade \& Bertini (2008b), Lecuona \& Pol (2008), Sereno \& Larsson (2009), Turner \& Sertich (2010), Montefeltro et al. (2011), Pol et al. (2012); MACN-PV-RN 22 (p), MACN-PV-RN 23 (p), MACN-PV-RN 1037 (p), MACN-PV-RN 1039 (p), MACN-PV-RN 1040 (p), MACN-PV-RN 1041 
(p), MACN-PV-RN 1048 (p), MACN-PV-RN 1127 (p), MACN-PV-RN 1038 (p), MACN-PV-RN 1045 (p), MLP 64-IV-16-5 (p), MLP 64-IV-16-7 (p), MLP 64-IV16-8 (p), MLP 64-IV-16-10 (p), MUCP-PV 35 (p), MUCP-PV 137 (p), MUCP-PV 147 (p), MUCP-PV 149 (p), MUCP-PV 198 (p), MUCP-PV 287 (p).

Pabwheshi pakistanensis - Wilson et al. (2001), Sereno \& Larsson (2009), Montefeltro et al. (2011), Pol \& Powell (2011), Pol et al. (2012).

Pakasuchus kaplimai - O’Connor et al. (2010).

Pehuenchesuchus enderi - Turner \& Calvo (2005), Pol \& Powell (2011), Pol et al. (2012); MAU-PV-CRS 440 (p).

Peirosaurus torminni - Price (1955); Gasparini et al. (1991), Martinelli et al. (2012); DGM $\underline{433 R}(\mathbf{p})$.

Pelagosuchus typus - Müller-Towe (2006), Pierce \& Benton (2006), Holliday \& Witmer (2009), Sereno \& Larsson (2009), Turner \& Sertich (2010), Pol \& Powell (2011), Andrade et al. (2011), Pol et al. (2012).

Pepesuchus deiseae - Campos et al. (2011); MN 7005 V (p).

Pissarrachampsa sera - Montefeltro et al. (2011); LPRP/USP 0017 (p), LPRP/USP 0018 (p), LPRP/USP 0019 (p).

Purranisaurus westermani - Gasparini (1980), Gasparini et al. (2008), Fernandez et al. (2011).

Racheosaurus gracilis - Young \& Andrade (2009), Young et al. (2010, 2011b, 2012); NHMUK 3948 (f).

Sebecus huilensis - Langston (1965); Buffetaut \& Hoffstetter (1977), Busbey (1986). 
Sebecus icaeorhinus - Colbert (1946), Turner \& Sertich (2010), Molnar (2010), Pol \& Powell (2011), Andrade et al. (2011), Pol et al. (2012); AMNH 3159 (p), AMNH 3160 (p).

Sebecus querejazus - Buffetaut \& Marshall (1991), Pol \& Powell (2011), Pol et al. (2012); MHCN-P 3701 (p), MHCN-P 13491 (p).

Simosuchus clarki - Sereno \& Larsson (2009), Georgi \& Krause (2010), Hill (2010), Kley et al. (2010), Sertich \& Groenke (2010), Turner \& Sertich (2010), Pol et al. (2012).

Sphagesaurus huenei - Pol (2003), Andrade \& Bertini (2008a), Turner \& Sertich (2010), Andrade et al. (2011), Pol et al. (2012).

Sphagesaurus montealtensis - Andrade \& Bertini (2008a), Andrade et al. (2011); MPMA $\underline{15001 / 90}(\mathbf{p})$.

Steneosaurus bollensis - Müller-Towe (2006), Sereno \& Larsson (2009), Turner \& Sertich (2010), Pol \& Powell (2011), Andrade et al. (2011), Pol et al. (2012).

Stolokrosuchus lapparenti - Larsson \& Gado (2000), Larsson \& Sues (2007), Turner \& Sertich (2010), Andrade et al. (2011); MNN GDF 600 (p).

Stratiotosuchus maxhechti - Campos et al. (2001), Pinheiro et al. (2008), Montefeltro et al. (2011), Riff \& Kellner (2011), Andrade et al. (2011); DGM 1477-R (p).

Trematochampsa taqueti - Buffetaut (1974, 1976); Ibc 3 (f), Ibc 6 (p), Ibc 7 (p), Ibc 17 (p), Ibc 19 (p), Ibc 21 (p), Ibc 23 (p), Ibc 24 (p), Ibc 26 (p), Ibc 29 (p), Ibc 33 (p), Ibc 35 (f), Ibc 36 (p), Ibc 38 (p), Ibc 39 (p), Ibc 41 (p), Ibc 42 (p), Ibc 45 (p), Ibc 46 (p), Ibc 48 (f), Ibc 52 (p), Ibc 54 (p), Ibc 55 (p), Ibc 56 (p), Ibc 58 (p), Ibc 59 (p), Ibc 60 (p), Ibc 61 (p), Ibc 63 (p), Ibc 64 (p), Ibc 65 (p), Ibc 66 (p), Ibc 67 (p), Ibc 68 (p), Ibc 71 (p), Ibc 73 (p), Ibc 74 (p), Ibc 76 (f), Ibc 77 (p), Ibc 79 (p), Ibc 80 (p), Ibc 81 
(p), Ibc 82 (p), Ibc 83 (p), Ibc 85 (p), Ibc 87 (p), Ibc 88 (p), Ibc 105 (p), Ibc 106 (p), Ibc 109 (p), Ibc 112 (p), Ibc 113 (p), Ibc 114 (p), Ibc 117 (p), Ibc 121 (p), Ibc 122 (p), Ibc 123 (p), Ibc 125 (p), Ibc 126 (p), Ibc 128 (p), Ibc 129 (p), Ibc 130 (p), Ibc 132 (p), Ibc 135 (p), Ibc 137 (p), Ibc 138 (p), Ibc 139 (p), Ibc 140 (f), Ibc 141 (p), Ibc 143 (p), Ibc 145 (p), Ibc 147 (p), Ibc 148 (p), Ibc 150 (p), Ibc 153 (p), Ibc 154 (p), Ibc 170 (f), Ibc 201 (f), Ibc 202 (p), Ibc 203 (p), Ibc 204 (p), Ibc 209 (p), Ibc 210 (p), Ibc 211 (p), Ibc 212 (p), Ibc 214 (f), Ibc 218 (p), Ibc 219 (p), Ibc 220 (f), Ibc 221 (p), Ibc 224 (p), Ibc 225 (p), Ibc 230 (p), Ibc 231 (f), Ibc 234 (f), Ibc 236 (p), Ibc 238 (p), Ibc 239 (p), Ibc 242 (p), Ibc 243 (p), Ibc 244 (p), Ibc 245 (p), Ibc 246 (p), Ibc 247 (p), Ibc 248 (p), Ibc 250 (p), Ibc 262 (f), Ibc 267 (f), Ibc 275 (f), Ibc 291 (f), Ibc 373 (p), Ibc 375 (p), Ibc 383 (p), Ibc 385 (p), Ibc 388 (p), Ibc 391 (p), Ibc 399 (p), Ibc 404 (f), Ibc 405 (p), Ibc 410 (f), Ibc 412 (p), Ibc 414 (p), Ibc 423 (f), Ibc 425 (f), Ibc 440 (p), Ibc 442 (p), Ibc 443 (p), Ibc 444 (p), Ibc 445 (p), Ibc 446 (p), Ibc 447 (p), Ibc 448 (p), Ibc 459 (f), Ibc 500 (f), Ibc 526 (f), Ibc 536 (f), Ibc 625 (f), Ibc 627 (f), Ibc 656 (p), Ibc 658 (f), Ibc 659 (p), Ibc 676 (p), Ibc 749 (f), Ibc 775 (f), Ibc 894 (f), Ibc 1060 (p), Ibc 1078 (f), Ibc 1080 (f), Ibc 1160 (f), Ibc 1180 (f), Ibc 1123 (f), Ibc 1164 (f), Ibc 1171 (f), Ibc 1312 (f), Ibc 1382 (p), Ibc 1388 (p), Ibc 1389 (p), Ibc 1393 (p), Ibc 1394 (p), Ibc 1397 (p), Ibc 1401 (p), Ibc 1402 (p), Ibc 1403 (p), Ibc 1404 (p), Ibc 1405 (p), Ibc 1419 (f), Ibc 1452 (f), Ibc 1453 (p), Ibc 1457 (p),Ibc 1459 (p), Ibc 1487 (p).

Uberabasuchus terrificus - Carvalho et al. (2004), Vasconcelos (2006), Andrade et al. (2011), Pol et al. (2012).

Urugaysuchus aznarezi - Rusconi (1933), Gasparini (1971), Sereno \& Larsson (2009), Sertich (2010), Andrade et al. (2011), Soto et al. (2011), Pol et al. (2012); FC-DPV $2320(\mathbf{p})$. 
Wargosuchus australis - Martinelli \& Pais (2008), Montefeltro et al. (2011); MOZ-PV 6134 (p).

Yacarerani boliviensis - Novas et al. (2009), Turner \& Sertich (2010), Andrade et al. (2011); MNK-PAL 5063 (f).

\section{Neosuchia}

Aegisuchus witmeri - Holliday \& Gardner (2012); $\underline{\text { ROM } 54530}$ (p).

Allodaposuchus precedens - Buscalioni et al. (2001, 2011), Delfino et al. (2008), Turner \& Sertich (2010), Andrade et al. (2011).

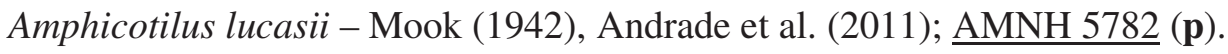

Bernissatia fagesi - Dollo (1883), Buscalioni et al. (1984), Norell \& Clark (1990), Sereno \& Larsson (2009), Pol et al. (2009), Turner \& Sertich (2010), Andrade et al. (2011).

Dyrosauridae Bolívia - MHNCN sem número (p).

Dyrosaurus phosphaticus - Jouve (2005), Brochu et al. (2002), Andrade et al. (2011).

Elosuchidae (ROM) - ROM sem número $(\mathbf{p})$.

Eutretauranosuchus delfisi - Mook (1967), Buffetaut \& Ingavat (1980), Smith et al. (2010), Andrade et al. (2011).

Forma do Maranhão - LPRP/USP 0617.

Goniopholis kiplingi - Andrade et al. (2011); DORCM 12154 (p).

Goniopholis simus - Owen (1878), Andrade et al. (2011); NHMUK R 5261 (f). 
Guarinisuchus munizi - Barbosa et al. (2008), Andrade et al. (2011); DG-CTG-UFPE 5723

(p).

Hylaeochampsa vectiana - Clark \& Norell (1992), Sereno \& Larsson (2009), Turner \&

Sertich (2010), Andrade et al. (2011), Pol et al. (2012); NHMUK 177 (f).

Hyposaurus rogersii - Denton et al. (1997), Pol et al. (2012).

Iharkutosuchus makadii - Osi et al. (2007), Osi (2008), Osi \& Weishampel (2009), Pol et al. (2009), Buscalioni et al. (2011).

Isisfordia duncani - Salisbury et al. (2006), Pol et al. (2009), Sereno \& Larsson (2009), Andrade et al. (2011).

Khoratosuchus jintasakuli - Lauprasert et al. (2009); NNRU-A 1803 (f).

Laganosuchus maghrebensis - Sereno \& Larsson (2009); UCRC PV 2 (p), ROM sem número (p).

Pholidosaurus pueberckensis - Meyer (1841), Owen (1878), Salisbury (2002), Fortier et al. (2011), Andrade et al. (2011), Pol et al. (2012); NHMUK R 3956 (f), NHMUK R $28432(\mathbf{f})$.

Pietraroiasuchus ormezzanoi - Buscalioni et al. (2011).

Rugosuchus nonganensis - Wu et al. (2001b), Pol et al. (2009), Turner \& Sertich (2010), Pol et al. (2012).

Sarcosuchus imperator - Sereno et al. (2001), Sereno \& Larsson (2009), Fortier et al. (2011), Andrade et al. (2011), Pol et al. (2012); MNN 603 (p), MNN 604 (p), MNN 606 (p), MNN sem número (p). 
Shamosuchus djadochtaensis - Mook (1924), Pol et al. (2009), Turner \& Sertich (2010), Pol et al. (2012); $\underline{\text { AMNH } 3159}$ (p), IGM 100/1195 (p).

Sunosuchus - Sunosuchus junggarensis e Sunosuchus thailandicus; Wu et al. (1996), Buffetaut \& Ingavati (1980), Andrade et al. (2011).

Susisuchus anatoceps - Salisbury et al. (2003), Salysbury et al. (2006), Pol et al. (2009), Figeuredo \& Kellner (2009), Figueiredo et al. (2011), Andrade et al. (2011).

Terminonaris robusta - Mook (1934), Wu et al. (2001a), Sereno et al. (2001), Sereno \& Larsson (2009), Turner \& Sertich (2010), Pol et al. (2012).

Theriosuchus - Theriosuchus pusillus, Theriosuchus guimarotae, Theriosuchus sympiestodon; Owen (1878), Norell \& Clark (1990), Salisburry (2002), Schwarz \& Salisburry (2005), Martin et al. (2010); NHMUK R 48330 (f).

\section{Crocodylia}

Alligator mississipiensis - Iordansky (1973), Brochu (1999, 2010), Sereno \& Larsson (2009), Turner \& Sertich (2010), Andrade et al. (2011), Pol et al. (2012); RM 2790 (p), RM $2801(\mathbf{p})$.

Crocodylus - Crocodylus porosus, Crocodylus niloticus, Crocodylus acutus; Iordansky (1973), Meden (1981, 1983); Brochu (1999, 2010), Brochu et al. (2010), Sereno \& Larsson (2009), Turner \& Sertich (2010), Andrade et al. (2011), Pol et al. (2012); ROM R 934 (p), ROM R 6837 (p), ROM R 6838 (p).

Gavialis gangeticus - Iordansky (1973), Brochu (1999), Sereno \& Larsson (2009), Turner \& Sertich (2010), Andrade et al. (2011), Pol et al. (2012); ROM R 19 (p), RM 4791 (p). 


\section{ABREVIAÇÕES INSTITUCIONAIS}

\section{Acrômios institucionais dos táxons visitados pessoalmente}

AMNH, American Museum of Natural History, Nova York, EUA; BPI, Bernard Price Institute; Johanesburgo, Africa do Sul; CMN, Canadian Museum of Nature, Ottawa, Canadá; DG-CTG-UFPE, Centro de Tecnologia e Geociências da UFPE, Recife, Brasil; DGM, Departamento Nacional de Produção Mineral, Rio de Janeiro, Brasil; DORCM, Dorset County Museum, Dorchester, Reino Unido; FC-DPV, Colección de Vertebrados Fósiles, Facultad de Ciencias, Montevideo, Uruguay; HLMD, Hessisches Landesmuseum, Darmstadt, Alemanha; Ibc, Muséum National d'Histoire Naturelle, Paris, França; IGM, Instituto de Geologia da Mongólia, Ulaan Bataar, Mongólia; IPUW, Institut fur Paläontologie, Universität Wienis, Viena, Áustria; LPRP/USP, Laboratório de Paleontologia de Ribeirão Preto-USP, Ribeirão Preto, Brasil; MACN, Museo Argentino de Ciências Naturales, Buenos Aires, Argentina; MAU, Museo Municipal Argentino Urquiza, Rincón de lós Sauces, Argentina; MHCN, Museo de Historia Natural Alcides d'Orbigny, Cochabamba, Bolívia; MLP, Museo de La Plata, La Plata, Argentina; MN, Museu Nacional, Rio de Janeiro, Brasil; MNN, Musée National du Niger, Niamey, Níger; MOZ, Museo Professor J. Olsacher, Zapala, Argentina; MPMA, Museu de Paleontologia de Monte Alto, Monte Alto, Brasil; MUCP, Museo de Geología y Paleontología, Universidad Nacional del Comahue, Neuquén, Argentina; MZSP, Museu de Zoologia da USP, São Paulo, Brasil; RM, Redpath Museum, Montreal, Canadá; ROM, Royal Ontario Museum, Toronto, Canadá; SAM, Iziko, South African Museum, Cidade do Cabo, Africa do Sul; SGP; Museu Geológico, Lisboa, Portugal; UCRC, University of Chicago Research Collection, Chicago, EUA; UFRJ, Coleção de Paleontologia de Vertebrados da Universidade Federal do Rio de Janeiro no Rio de Janeiro, Rio de Janeiro, Brasil. 
Coleções com táxons depositados analisados somente por material fotográfico

MNK, Museo Noel Kempff Mercado, Santa Cruz de La Sierra, Bolívia; NHMUK, Natural

History Museum, Londres, Reino Unido; NNRU, Nakhon Ratchsima Rajabhat, Nakhon

Ratchasima, Tailândia; PVL, Instituto Miguel Lillo, San Miguel de Tucumán, Argentina. 


\section{APÊNDICE II. CARACTERES UTILIZADOS NA ANÁLISE DE PARCIMÔNIA}

Os caracteres utilizados nas análises de parcimônia estão listados abaixo. Os caracteres de 1 a 477 são resultantes da revisão filogenética desenvolvida, ao passo que os caracteres 478 a 494 são apresentados pela primeira vez e representam novas propostas de homologias reconhecidas. Os caracteres resultantes da revisão filogenética são precedidos por uma anotação que lista os autores originais do caráter, seguido da inclusão dos mesmos dentre as análises bases da revisão filogenética (Sereno \& Larsson 2009, Turner \& Sertich 2010, Pol \& Powell 2011, Andrade et al. 2011, Pol \& Powell 2012), seguidos do número do caráter em tais análises. As análises auxiliares são listadas quando estas foram utilizadas para a redefinição do enunciado, ou estado de caráter. Foi adicionada a anotação (mod) na frente da citação dos trabalhos quando este foi modificado extensivamente (adição/remoção de estados de caracteres, ou as homologias foram redefinidas). Os novos caracteres são precedidos pela anotação (novo).

1. (mod) Clark (1994)-C1: Superfície dorsal dos ossos do crânio: lisa (0), ornamentada (1).

2. (mod) Sereno \& Larsson (2009)-C1; (mod) Turner \& Sertich (2010)- C1; (mod) Pol \& Powell (2011)-C1; (mod) Andrade et al. (2011)-C10-11; (mod) Pol et al. (2012)- C1: Superfície dorsal ornamentada dos ossos do crânio: superfície com poucas ornamentações (0), superfície fortemente ornamentada com punctuações (pits) e rugas (grooves) (1).

3. Gasparini et al. (2006)-C252; Turner \& Sertich (2010)- C252; Pol \& Powell (2011)C252; Pol et al. (2012)-C252: Superfície externa do rostro: não ornamentada (0), ornamentada (1). 
4. Andrade et al. (2011)-C09: Projeção dorsal do rostro: ausente, rostro com perfil reto ou direcionado ventralmente (0), rostro com uma curvatura dorsal bem marcada (1).

5. (mod) Clark (1994)- C2; Sereno \& Larsson (2009)-C2; Turner \& Sertich (2010)- C2; Pol \& Powell (2011)-C2; Pol et al. (2012)-C2: Expansão do crânio na região das órbitas: gradual (0), expansão abrupta (1).

6. $\quad$ Ortega et al. (2000)- C130; Turner \& Sertich (2010)- C178; Pol \& Powell (2011)-C178; (mod) Andrade et al. (2011)-C81; Pol et al. (2012)-C178: Contorno lateral do crânio em vista dorsal: retilíneo (0), sinusoidal (1).

7. (mod) Wu et al. (1997)-C4; Sereno \& Larsson (2009)-C3; (mod) Andrade et al. (2011)C5: Tamanho do rostro (margem anterior da órbita até a região anterior do rostro) relativo ao restante do crânio: de mesmo tamanho ou mais longo (0), mais curto (1).

8. (mod) Clark (1994)- C3; (mod) Sereno \& Larsson (2009)- C4; Turner \& Sertich (2010)C3; Pol \& Powell (2011)-C3; (mod) Andrade et al. (2011)-C6; Pol et al. (2012)- C3: Proporções do rostro: oreinirostral estreito (0), oreinirostral largo (1), tubular (2), platirostral (3).

9. (mod) Clark (1994)-C6; (mod) Sereno \& Larsson (2009)-C8; (mod) Turner \& Sertich (2010)- C6; (mod) Pol \& Powell (2011)- C6; (mod) Andrade et al. (2011)- C31; Pol et al. (2012)- C6: Orientação da narina externa: anterolateral (0), dorsal (1).

10. Clark (1994)-C66; Turner \& Sertich (2010)-C66; Pol \& Powell (2011)-C66; (mod) Andrade et al. (2011)-C37; Pol et al. (2012)-C66: Narina externa: divididas por um septo (0), confluente (1).

11. (mod) Wilkinson et al. (2008)-C18; (mod) Young \& Andrade et al. (2009)-C18; (mod) Young et al. (2011)-C18: Orientação principal das órbitas: dorsal ou dorsolateral (0), lateral (1).

12. Andrade et al. (2011)-C43: Fenestra antero-orbital: presente (0), ausente (1). 
13. (mod) Clark (1994)- C67; Turner \& Sertich (2010)- C67; (mod) Pol \& Powell (2011)67; (mod) Andrade et al. (2011)-C44- 48; Pol et al. (2012)- C67: Tamanho da fenestra antero-orbital externa (senso Witmer, 1997): tão grande quanto a orbita (0), aproximadamente metade do tamanho da órbita (1), muito menor que a órbita (2).

14. (mod) Gasparini et al. (2006)- C246; Sereno \& Larsson (2009)- C6; Turner \& Sertich (2010)- C246; Pol \& Powell (2011)- C287; Andrade et al. (2011)- C46; Pol et al. (2012)- C287: Formato da fenestra antero-orbital externa: arredondada ou alta dorsoventralmente (0), baixa e alongada em formato de fenda (1), triangular com ápice direcionado dorsalmente (2).

15. Ortega et al. (2000)- C72; Turner \& Sertich (2010)- C224; Pol \& Powell (2011)- C224; Pol et al. (2012)- C224: Fenestra supratemporal externa: presente (0), ausente (1).

16. (mod) Andrade et al. (2011)- C111: Fenestra supratemporal externa: quadrada a subretangular (0), circular à elíptica (1), triangular com ápice antero-medialmente direcionado (2).

17. (mod) Clark (1994)- C68; Sereno \& Larsson (2009)- C7; (mod) Turner \& Sertich (2010)- C68; (mod) Pol \& Powell (2011)- C68; (mod)- Andrade et al. (2011)- C106107- 109; (mod) Pol et al. (2012)- C68: Comprimento anteroposterior da fenestra temporal superior: igual ou menor que comprimento da órbita (0), muito maior que a órbita (1).

18. Andrade et al. (2011)-C162: Fenestra temporal inferior em comparação à órbita: reduzida, menor que $20 \%$ da área da órbita (0), grande, maior que 50\% da área da órbita (1).

19. Ortega et al. (2000)- C46; Andrade et al. (2011)- C165: Orientação da fenestra temporal inferior: orientada lateralmente (0), laterodorsalmente (1). 
20. Andrade et al. (2011)- C164: Formato da fenestra temporal inferior: claramente triangular (0), elíptica a subpoligonal (1).

21. (mod) Clark (1994)- C39; Sereno \& Larsson (2009)- C127; Turner \& Sertich (2010)C39; Pol \& Powell (2011)- C39; Young et al. (2011b)- C187; Pol et al. (2012)- C39: Abertura coanal: continua com a margem do pterigoide (exceto anteriormente e anterolateralmente) (0), abertura no palato através de uma depressão profunda (choanal groove) (1).

22. (mod) Andrade \& Bertini (2008a)- C91; (mod) Andrade et al. (2011)- C239: Formato da choanal groove: subcircular, elíptica, ou lanceolada (0), triangular com ápice anterior (1), retangular (2).

23. (mod) Clark (1994)- C42; (mod) Ortega et al. (2000)- C139; (mod) Sereno \& Larsson (2009)- C133; (mod) Turner \& Sertich (2010)- C42; Pol \& Powell (2011)- C42; (mod) Andrade et al. (2011)- C233- 234- 240- 260; (mod) Pol et al. (2012)- C42: Tamanho da abertura coanal (choanal groove): largura total menor que 30\% da distância entre as margens laterais da asa do pterigoide (0), largura total maior que 50\% da distância das margens laterais das asas do pterigóide (1).

24. (mod) Clark (1994)- C69; Sereno \& Larsson (2009)- C142; Turner \& Sertich (2010)C69; Pol \& Powell (2011)- C69; Andrade et al. (2011)- C244; Pol et al. (2012)- C69: Abertura coanal: não septada (0), parcialmente septada (1), completamente septada (2).

25. Pol \& Norell (2004a)- C183; Turner \& Sertich (2010)- C234; Pol \& Powell (2011)C234; Andrade et al. (2011)- C241; Pol et al. (2012)- C234: Abertura coanal: aberta posteriormente (0), fechada posteriormente por uma projeção ventral do pterigóide (1).

26. (mod) Andrade et al. (2011)- C206: Fenestra suborbital: pequena (0), subigual ou maior que a órbita (1). 
27. Andrade \& Bertini (2008a)- C86; Andrade et al. (2011)- C207: Formato da margem anterior da fenestra suborbital: arredondado (0), em um ângulo agudo, formando uma fissura (1).

28. Montefeltro et al. (2011)- C49: Fenestra pós-temporal: presente (0), ausente (1).

29. (mod) Sereno \& Larsson (2009)- C158- 166; (mod) Turner \& Sertich (2010)- C268; (mod)- Pol \& Powell (2011)- C268; (mod) Andrade et al. (2011)- C277- 278- 302- 306307; (mod) Pol et al. (2012)- C268: Abertura ótica: aberta posteriormente (0), fechada posteriormente pelo quadrado e otoccipital (1).

30. (mod) Andrade et al. (2011)- C302: Morfologia do meato auditivo (incluindo abertura ótica e abertura ótica da passagem crânio-quadrado, mas não o forâmen pré-ótico do sifão e fenestras quadradas quando presentes): subpoligonal à elíptica (0), triangular com ápice dorsal (1)

31. (mod) Andrade et al. (2011)- C303: Tamanho do meato auditivo externo (incluindo abertura ótica e abertura ótica da passagem crânio-quadrado, mas não o forâmen préótico do sifão e fenestras quadradas quando presentes): pequeno, não completamente visível em vista lateral (0), tamanho mediano (1), conspicuamente grande (2).

32. (mod) Clark (1994)- C49; (mod) Brochu (1999)- C141; (mod) Sereno \& Larsson (2009)- C158- 166; (mod) Turner \& Sertich (2010)- C49-268; (mod) Pol \& Powell (2011)- C49; (mod) Andrade et al. (2011)- C277- 278- 306- 307; (mod) Pol et al. (2012)- C49- 268: Canal crânio-quadrado: aberto lateralmente (0), fechado lateralmente (1).

33. (mod) Clark (1994)- C49; (mod) Brochu (1999)- C141; (mod) Sereno \& Larsson (2009)- C158- 166; (mod) Turner \& Sertich (2010)- C49-268; (mod)- Pol \& Powell (2011)- C49; (mod) Andrade et al. (2011)- C277- 278- 306- 307; (mod) Pol et al. 
(2012)- C49- 268: Abertura occipital do canal crânio-quadrado: próximo a lateral do crânio (0), medialmente localizado e ventral ao processo paraoccipital.

34. Brochu (1999)- C101; Sereno \& Larsson (2009)- C9: Saliência dorsal mediana no rostro: ausente (0), presente (1).

35. Jouve (2009)- C341; Fortier et al. (2011)- C261: Largura da maxila em relação a largura do rostro ao nível dos alvéolos maxilares 4 e 5: pré-maxila mais estreita (0), pré-maxila mais larga (1).

36. (mod) Andrade et al. (2011)- C62: Pré-maxila anterior à narina externa: fortemente suturadas (0), fracamente suturadas, algumas vezes não em contato (1).

37. Clark (1994)- C5; Turner \& Sertich (2010)- C5; Pol \& Powell (2011)- C5; Andrade et al. (2011)- C33; Pol et al. (2012)- C5: Pré-maxila anterior à narina externa: estreita (0), larga (1).

38. Jouve (2004)- C205; Fortier et al. (2011)- C263: Distância entre extremidade anterior do rostro e extensão mais anterior da sutura pré-maxila/maxila em vista dorsal em relação à distância entre extensão mais anterior da sutura pré-maxila/maxila em vista dorsal e a extremidade posterodorsal da pré-maxila: distância entre extremidade anterior do rostro maior (0), distância entre extremidade anterior do rostro menor (1).

39. Andrade et al. (2011)- C38: Projeção da barra inter-narial relativa ao corpo principal da pré-maxila: barra não projeta anterior ao corpo da pré-maxila (0), barra projetada anterior ao corpo principal da pré-maxila (1).

40. Clark (1994)- C4; (mod) Sereno \& Larsson (2009)- C79; Turner \& Sertich (2010)- C4; Pol \& Powell (2011)- C4; (mod) Andrade et al. (2011)- C39- C24; Pol et al. (2012)- C4: Participação da pré-maxila na barra inter-narial: formando pelo menos a metade ventral (0), pré-maxila com pouca participação na barra inter-narial (1). 
41. Gasparini et al. (2006)- C237; Turner \& Sertich (2010)- C237; Pol \& Powell (2011)C237; Andrade et al. (2011)- C71; Pol et al. (2012)- C237: Forâmen na depressão perinarial na pré-maxila: ausente (0), presente (1).

42. Andrade et al. (2011)- C29: Cristas peri-narial: ausente (0), presente na região lateral e posterior da narina (1).

43. Andrade et al. (2011)- C41: Fossa pós-narial: ausente (0), presente (1)

44. (mod) Clark (1994)- C9; (mod) Turner \& Sertich (2010)- C9; (mod): Montefeltro et al. (2011)- C1; (mod) Andrade et al. (2011)- C56- 57- 410; (mod) Pol et al. (2012)- C9: Sutura pré-maxila-maxila: confluente (0), aberta ventralmente (1).

45. (mod) Clark (1994)- C9; (mod) Turner \& Sertich (2010)- C9; (mod) Montefeltro et al. (2011)- C1; (mod) Pol \& Powell (2011)- C9; (mod) Andrade et al. (2011)- C56- 57- 58410; (mod) Pol et al. (2012)- C9: Abertura da sutura pré-maxila-maxila: abertura da sutura pouco desenvolvida, presente na região ventral da sutura (0), sutura aberta bem desenvolvida, frequentemente envolvendo pelo menos parcialmente o dente oposto da mandíbula (1), sutura aberta em formato de fenda presente ao longo de toda a sutura (2).

46. (mod) Clark (1994)- C13- 14; Pol (1999)- C136; (mod) Sereno \& Larsson (2009)- C8; (mod) Turner \& Sertich (2010)- C13- 14- 124; (mod) Pol \& Powell (2011)- C13- 14124; (mod) Andrade et al. (2011)- C36; (mod) Pol et al. (2012)- C13- 14- 124: Extensão dos nasais na narina externa: ausente pelo contato entre as maxillas (0), ausente pelo contato entre as pré-maxillas (1), participa medialmente da margem dorsal/posterior da narina externa (2), participa medialmente e lateralmente da margem dorsal/posterior da narina externa (3).

47. Pol (1999)- C138; Turner \& Sertich (2010)- C125; Pol \& Powell (2011)- C125; Andrade et al. (2011)- C59; Pol et al. (2012)- C125: Processo posterodorsal da pré- 
maxila: ausente (0), presente estendendo posterodorsalmente em formato de cunha entre maxila e nasal (1).

48. Clark (1994)- C8; Turner \& Sertich (2010)- C8; Pol \& Powell (2011)- C8; Andrade et al. (2011)- C63; Pol et al. (2012)- C8: Contato entre pré-maxila e maxila: pré-maxila sobrepõe frouxamente o processo anterodorsal da maxilla (0), fortemente suturados (butt joint) ao longo da região ventral da sutura (1).

49. Wu et al. (1997)- C127; Turner \& Sertich (2010)- C207; Pol \& Powell (2011)- C207; Andrade et al. (2011)- C86; Pol et al. (2012)- C207: Superfície posterolateral da maxilla: sem uma depressão marcada (0), com uma depressão bem marcada (1).

50. Andrade et al. (2011)- C92: Contato nasal/maxila: contato extenso (0), contato reduzido (1).

51. Andrade et al. (2011)- C78: Participação da maxila na margem da órbita: ausente (0), presente (1).

52. Gasparini et al. (2006)- C257; Sereno \& Larsson (2009)- C10; Turner \& Sertich (2010)C257; Montefeltro et al. (2011)- C2; Pol \& Powell (2011)- C257; Andrade et al. (2011)C77; Pol et al. (2012)- C257: Nasais: pareados (0), parcialmente ou completamente fundidos (1).

53. (mod) Montefeltro et al. (2011)- C3: Superfície dorsal do nasal: arredondado ou plano (0), formando uma barra sagital (1).

54. Pol (1999)- C140; Turner \& Sertich (2010)- C127; Pol \& Powell (2011)- C127; Andrade et al. (2011)- C76; Pol et al. (2012)- C76: Margem lateral do nasal posterior à narina externa: côncava (0), retilínea (1).

55. Pol (1999)- C141; (mod) Turner \& Sertich (2010)- C128; (mod) Pol \& Powell (2011)C128; (mod) Pol et al. (2012)- C128: Margens laterais dos nasais: paralelas (0), convergente anteriormente (1). 
56. Pol \& Apesteguia (2005)- C223; Turner \& Sertich (2010)- C228; Pol \& Powell (2011)C228; Pol et al. (2012)- C228: Região posterolateral dos nasais: ocupando parte dorsal do rostro (0), região posterolateral do nasal defletido ventralmente (1).

57. Pol \& Powell (2011)- C288: Exposição do nasal na região lateral do rostro: defletindo gradualmente da região dorsal do crânio (0), defletindo abruptamente, formando aproximadamente $90^{\circ}$ em relação a face dorsal (1).

58. Montefeltro et al. (2011)- C4: Porção posterior da superfície dorsal do nasal: arredondada ou plana (0), rugosa e deprimida (1).

59. Ortega et al. (2000)- C70; Turner \& Sertich (2010)- C172; Young et al. (2011)- C40; Andrade et al. (2011)- C49; Pol et al. (2012)- C172: Relação do nasal e a fenestra antero-orbital: nasal incluído na fenestra (0), nasal excluído da fenestra (1).

60. (mod) Clark (1994)- C11; Sereno \& Larsson (2009)- 21; (mod) Turner \& Sertich (2010)- C11; (mod) Pol \& Powell (2011)- C11; (mod) Young et al. (2011)- C97; (mod) Andrade et al. (2011)- C93-98; (mod) Pol et al. (2012)- C11: Contato entre nasal e lacrimal: presente (0), ausente (1).

61. Clark (1994)- C12; Turner \& Sertich (2010)- C12; Pol \& Powell (2011)- C12; Pol et al. (2012)- C12: Contato nasal/lacrimal: contato através da margem medial do lacrimal (0), contato através da margem lateral e anterior do lacrimal (1).

62. Ortega et al. (2000)- C24; Sereno \& Larsson (2009)- C11; Turner \& Sertich (2010)C165; Pol \& Powell (2011)- C165; Pol et al. (2012)- C165: Margem caudal do nasal: convergente medialmente (0), separado pelo processo anterior do frontal (1).

63. Montefeltro et al. (2011)- C10; (mod) Andrade et al. (2011)- C75; Sulco na porção sagittal da região posterior do nasal e anterior do frontal: ausente (0), presente (1).

64. (mod) Brochu (1999)- C117; Sereno \& Larsson (2009)- C23: Comprimento total do lacrimal em comparação com o pré-frontal: mais longo (0), subigual (1), mais curto (2). 
65. Sereno \& Larsson (2009)- C22; (mod) Andrade et al. (2011)- C94- 96: Formato do lacrimal: mais longo que largo (0), tão longo quanto largo (1).

66. (mod) Sereno \& Larsson (2009)- C72; (mod) Montefeltro et al. (2011)- C12: Faceta do pré-frontal e lacrimal para o suporte do palpebral: pouco desenvolvido, não se estendendo lateralmente sobre a órbita (0), bem desenvolvido, se estendendo lateralmente sobre a órbita (1).

67. (mod) Pol et al. (2009)- C277; (mod) Turner \& Sertich (2010)- C277; (mod) Pol \& Powell (2011)- C277; (mod) Pol et al. (2012)- C277: Formato geral da faceta do préfrontal e lacrimal para o suporte do palpebral: Bordas pouco marcadas e faceta alongada anteroposteriormente (0), bordas bem delimitadas e faceta hemisférica (1).

68. Gasparini et al. (2006)- C256; Turner \& Sertich (2010)- C247; Pol \& Powell (2011)C247; Andrade et al. (2011)- C125; Pol et al. (2012)- C247: Desenvolvimento lateral do pré-frontal: reduzido (0), bem desenvolvido se estendendo lateralmente sobre a órbita (1).

69. Pol \& Powell (2011)- C289; Pol et al. (2012)- C289: Crista na sutura pré-frontal/frontal: ausente (0), presente (1).

70. (mod) Gomani (1997)- C4; Sereno \& Larsson (2009)- C15; Turner \& Sertich (2010)C111; Pol \& Powell (2011)- C111; Pol et al. (2012)- C111: Pré-frontal anterior à órbita: alongado, orientado paralelo ao eixo anteroposterior do crânio (0), curto e largo, orientado posteromedialmente- anterolateralmente.

71. (mod) Andrade et al. (2011)- C99: Crista pré-frontal/lacrimal dorsal à órbita: ausente (0), presente (1).

72. Gasparini et al. (2006)- C256; Turner \& Sertich (2010)- C256; Pol \& Powell (2011)C256; Pol et al. (2012)- C256: Borda orbital do pré-frontal e lacrimal: margens planas (0), formando margens elevadas (1). 
73. (mod) Montefeltro et al. (2011)- C5: Contato medial entre os pré-frontais: ausente, contato amplo entre nasal e frontal (0), presente (1).

74. (mod) Montefeltro et al. (2011) -C5: Contato medial entre os pré-frontais: presente em um ponto das margens mediais (0), presente ao longo de grande parte das margens mediais (1).

75. Clark (1994)- C21; Turner \& Sertich (2010)- C21; Pol \& Powell (2011)- C21; Andrade et al. (2011)- C132; Pol et al. (2012)- C21: Frontais: pareados (0), fundidos (1).

76. Clark (1994)- C20; Turner \& Sertich (2010)- C20; Pol \& Powell (2011)- C20; (mod) Andrade et al. (2011)- C134; Pol et al. (2012)- C20: Largura dos frontais entre as órbitas: estreito, tão largo quanto os nasais (0), largo, duas vezes mais largos que os nasais (1).

77. Andrade et al. (2011)- C137: Morfologia da margem anterior do frontal: truncada (0), ou com seção decrescente (1).

78. Clark (1994)- C22; Sereno \& Larsson (2009)- C28; Turner \& Sertich (2010)- C22; Pol \& Powell (2011)- C22; (mod) Montefeltro et al. (2011)- C11; Andrade et al. (2011)C102; Pol et al. (2012)- C22: Superfície dorsal do frontal: plano (0), com uma crista longitudinal (1).

79. (mod) Montefeltro et al. (2011)- C11: Crista longitudinal do frontal: restrita à região posterior do frontal (0), crista na região mediana do frontal, ou ocupando todo o comprimento do frontal (1), crista restrita a região anterior do frontal (2).

80. Andrade et al. (2011)- C140: Extensão anterior do frontal: longo, estendendo anterior à orbita (0), curto, não se estendendo anterior à orbita (1).

81. Pol et al. (2009)- C276; Sereno \& Larsson (2009)- C19; Turner \& Sertich (2010)- C276; Pol \& Powell (2011)- C276; Pol et al. (2012)- C276: Crista transversal na superfície dorsal do frontal anterior às órbitas: ausente (0), presente (1). 
82. Riff \& Kellner (2011)- C260; (mod) Pol \& Powell (2011)- C290; Montefeltro et al. (2011)- C9; Pol et al. (2012)- C290: Frontal posterior às órbitas: plana ou ligeiramente côncavo (0), marcadamente côncavo, não considerando a margem das órbitas elevadas, quando presente (1).

83. (mod) Clark (1994)- C15; Turner \& Sertich (2010)- C15; Pol \& Powell (2011)- C15; Andrade et al. (2011)- C127- 128; Pol et al. (2012)- C15: Processo descendente do préfrontal (prefrontal pillar): não contata o palato (0), contata o palato (1).

84. (mod) Ortega et al. (2000)- C30; (mod) Turner \& Sertich (2010)- C182; (mod) Pol \& Powell (2011)- C182; (mod) Andrade et al. (2011)- C129- 130; (mod) Pol et al. (2012)C182: Região dorsal do prefrontal pillar (independente de contato com o palato): transversalmente expandido (0), longitudinalmente expandido (1).

85. (mod) Ortega et al. (2000)- C30; (mod) Turner \& Sertich (2010)- C182; (mod) Pol \& Powell (2011)- C182; (mod) Andrade et al. (2011)- C129- 130; (mod) Pol et al. (2012)C182: Região ventral do prefrontal pillar quando integrado ao palato: transversalmente expandido (0), em formato colunar (1).

86. Sereno et al. (2001)- C27; Turner \& Sertich (2010)- C238; Pol \& Powell (2011)- C238; Andrade et al. (2011)- C142; Pol et al. (2012)- C238: Ramo anterior do frontal: não se estendendo anterior à margem anterior dos pré-frontais $(0)$, se estendendo anteriormente às margens do pré-frontais (1).

87. (mod) Brochu (1999)- C103; (mod) Sereno \& Larsson (2009)- C14; Turner \& Sertich (2010)- C266; Pol \& Powell (2011)- C266; Andrade et al. (2011)- C135- 157; Pol et al. (2012)- C266: Margens laterais do frontal relativo à superfície dorsal do frontal: em nível (0), elevada, formando uma crista na margem da órbita (1). 
88. Andrade et al. (2011)- C141: Participação do frontal na márgem primária da órbita: participação extensa na órbita primária (0), excluída da órbita pelo contato entre préfrontal-pós-orbital (1).

89. (mod) Clark (1994)- C28; Turner \& Sertich (2010)- C28; Pol \& Powell (2011)- C28; (mod) Andrade et al. (2011)- C152- 153; Pol et al. (2012)- C28- Processo anterolateral do pós-orbital: ausente, ou pouco desenvolvido (0), bem desenvolvido (1).

90. Clark (1994)- C16; Turner \& Sertich (2010)- C16; Pol \& Powell (2011)- C16; (mod) Young et al. (2011)- C35; Andrade et al. (2011)- C200; Pol et al. (2012)- C16: Contato pós-orbital-jugal: pós-orbital anterior ao jugal (0), pós-orbital medial ao jugal (1), pósorbital lateral ao jugal (2).

91. (mod) Clark (1994)- C23; (mod) Buckley \& Brochu (1999)- C81; (mod) Turner \& Sertich (2010)- C23; (mod) Pol \& Powell (2011)- C23; (mod) Montefeltro et al. (2011)C7; (mod) Andrade et al. (2011)- C122- 143: Sutura parietal e pós-orbital: ausente da superfície dorsal do crânio e fossa supratemporal (0), ausente da superfície dorsal do crânio, mas presente na região ventral da fossa supratemporal (1), ausente da superfície dorsal do crânio, mas presente extensivamente na região ventral da fossa supratemporal (2), presente na fossa supratemporal e na superfície dorsal do crânio (3).

92. Ortega et al. (2000)- C33; Turner \& Sertich (2010)- C166; Pol \& Powell (2011)- C166; Andrade et al. (2011)- C151; Pol et al. (2012)- C166: Comprimento relativo entre pósorbital e squamosal: squamosal mais longo (0), pós-orbital mais longo (1).

93. Clark (1994)- C24; Turner \& Sertich (2010)- C24; Pol \& Powell (2011)- C24; Andrade et al. (2011)- C118; Pol et al. (2012)- C24: Conformação da superfície dorsal do crânio: complexa (0), superfície dorsal do crânio formado pelo esquamosal e pós-orbital com projeções laterais sobre o quadrado (1). 
94. Clark (1994)- C33; (mod) Sereno \& Larsson (2009)- C33- 63; Turner \& Sertich (2010)C33; Pol \& Powell (2011)- C33; Young et al. (2011)- C2; (mod) Andrade et al. (2011)C145; Pol et al. (2012)- C33: Região entre as bordas mediais das fenestras temporais superiores: região plana (0), uma crista sagittal (1).

95. (mod) Norell (1988)- C9; (mod) Brochu (1999)- C87; (mod) Sereno \& Larsson (2009)C32; (mod) Andrade et al. (2011)- C108: Ossos bordejando a fenestra temporal superior: não se projetando sobre a abertura da fenestra temporal superior (0), se projetando sobre a abertura da fenestra temporal superior (1).

96. (mod) Norell (1988)- C9; (mod) Brochu (1999)- C87; (mod) Sereno \& Larsson (2009)C32-(mod); Andrade et al. (2011)- C108: Extensão dos ossos se projetando sobre a fenestra temporal superior: restrito a margem medial e posterior da fenestra (0), presente sobre todo o perímetro da fenestra temporal superior (1).

97. (mod) Montefeltro et al. (2011)- C13: Margens medial da fenestra temporal superior: lisas (0) hipertrofiadas (1).

98. Clark (1994)- C31; Turner \& Sertich (2010)- C31; Pol \& Powell (2011)- C31; Pol et al. (2012)- C31: Barra entre a órbita e a fenestra temporal superior: barra sólida com superfície dorsal ornamentada (0), barra estreita com ornamentações restrita a face anterior (1).

99. Gasparini et al. (2006)- C254; Turner \& Sertich (2010)- C254; Pol \& Powell (2011)C254; Young et al. (2011)- C26; Pol et al. (2012)- C254: Ângulo entre as margens anterior e medial da fenestra temporal superior externa: angulo maior ou igual a $90^{\circ}(0)$, ângulo aproximadamente de $45^{\circ}$ (1).

100. Brochu (1999)- C92; Turner \& Sertich (2010)- C265; Pol \& Powell (2011)- C265; Andrade et al. (2011)- C105; Pol et al. (2012)- C265: Região anteromedial da fossa supratemporal: presente (0), ausente, fossa vertical nessa região (1). 
101. (mod) Andrade et al. (2011)- C146: Superfície dorsal do parietal: no mesmo nível do squamosal (0), projetada dorsalmente relativa ao teto craniano (1), marcadamente deprimida em relação ao teto craniano (2).

102. (mod) Wu et al. (1997)- C123; (mod) Turner \& Sertich (2010)- C206; (mod) Pol \& Powell (2011)- C206; Andrade et al. (2011)- C292; (mod) Pol et al. (2012)- C206: Largura do teto craniano em relação a região ventral: tão largo quanto, quadrados encoberto pelo esquamosal (0), mais estreito, mas esquamosal ainda cobrindo parte laterodistal dos quadrados (1), mais estreito, expondo a região laterodistal dos quadrados (2).

103. Andrade et al. (2011)- C149: Margens da barra temporal superior: retilíneas ou ligeiramente convexa (0), margens sinusoidais (1).

104. (mod) Ortega et al. (2000)- C157; (mod) Turner \& Sertich (2010)- C181; (mod) Pol \& Powell (2011)- C181; Montefeltro et al. (2011)- C17; Andrade et al. (2011)- C148; (mod) Pol et al. (2012)- C181: Margens laterais dos esquamosais e pós-orbitais: paralelas (0), divergindo posteriormente (1).

105. (mod) Clark (1994)- C65; (mod) Sereno \& Larsson (2009)- C31; (mod) Turner \& Sertich (2010)- C65; (mod) Pol \& Powell (2011)- C65; (mod) Young et al. (2011)- C17; (mod) Andrade et al. (2011)- C186; (mod) Pol et al. (2012)- C65: Palpebrais: ausente (0), presente (1).

106. (mod) Clark (1994)- C65; (mod) Sereno \& Larsson (2009)- C31; (mod) Turner \& Sertich (2010)- C65; (mod) Pol \& Powell (2011)- C65; (mod) Young et al. (2011)- C17; (mod) Andrade et al. (2011)- C186- 187; (mod) Pol et al. (2012)- C65: Palpebral posterior: ausente (0), presente (1).

107. (mod) Clark (1994)- C65; (mod) Sereno \& Larsson (2009)- C31; (mod) Turner \& Sertich (2010)- C65; (mod) Pol \& Powell (2011)- C65; (mod) Young et al. (2011)- C17; 
(mod) Andrade et al. (2011)-187; (mod) Pol et al. (2012)- C65: Formato do palpebral anterior: arredondado (0), superficialmente triangular, com um processo posterolateral (1).

108. Pol \& Norell (2004b)- C181; Turner \& Sertich (2010)- C214; Pol \& Powell (2011)C214; (mod) Montefeltro et al. (2011)- C21; (mod) Andrade et al. (2011)- C188- 189190; Pol et al. (2012)- C214: Palpebrais: separados ou fracamente suturados à margem lateral do frontal (0), suturados extensivamente à margem lateral do frontal (1).

109. Wilkinson et al. (2008)- C27; Young and Andrade (2009)- C27; Young et al. (2011)C27: Sutura entre frontal e pós-orbital na margem anterior da fenestra temporal superior externa: no mesmo nível da barra intertemporal (0), ventral à barra intertemporal (1).

110. Clark \& Sues (2002)- C13; (mod) Sereno \& Larsson (2009)- C56: Margem lateral do squamosal: lisa (0), com um sulco para a aba do ouvido externo (1).

111. (mod) Clark \& Sues (2002)- C13; Larsson \& Sues (2007)- C32; Sereno \& Larsson (2009)- C56: Margens do sulco para a aba do ouvido externo: margem ventral lateral à margem dorsal (0), margem ventral diretamente ventral à margem dorsal (1).

112. Gasparini et al. (2006)- C250; Sereno \& Larsson (2009)- C62; Turner \& Sertich (2010)C250; Pol \& Powell (2011)- C250; Pol et al. (2012)- C250: Processo posteromedial do squamosal orientado transversalmente (0), orientado posterolateralmente (1).

113. Gasparini et al. (2006)- C251; Turner \& Sertich (2010)- C251; Pol \& Powell (2011)C251; Pol et al. (2012)- C251: Superfície dorsal do esquamosal: retilínea (0), côncava dorsalmente (1).

114. Ortega et al. (2000)- C75; Sereno \& Larsson (2009)- C60; Turner \& Sertich (2010)C173; Pol et al. (2012)- C173: Abertura anterior do forâmen temporo-orbital: presente (0), ausente (1). 
115. (mod) Clark (1994)- C36; (mod) Ortega et al. (2000)- C42; (mod) Sereno \& Larsson (2009)- C57- 58; (mod) Turner \& Sertich (2010)- C36; (mod) Montefeltro et al. (2011)C18- 38; (mod) Pol \& Powell (2011)- C36; (mod) Andrade et al. (2011)- C154- 156; (mod) Pol et al. (2012)- C36: Processo posterolateral do squamosal: ausente (0), presente (1).

116. (mod) Ortega et al. (2000)- C42; (mod) Sereno \& Larsson (2009)- C58; (mod) Turner \& Sertich (2010)- C36; (mod) Montefeltro et al. (2011)- C18- 38; (mod) Pol \& Powell (2011)- C36; (mod) Andrade et al. (2011)- C154- 156; (mod) Pol et al. (2012)- C36: Projeção do processo posterolateral do squamosal: paralela a superfície do teto craniano (0), ventralmente direcionado (1), dorsalmente direcionado (2).

117. (mod) Ortega et al. (2000)- C42; (mod) Sereno \& Larsson (2009)- C58; (mod) Turner \& Sertich (2010)- C36; (mod) Montefeltro et al. (2011)- C18- 38; (mod) Pol \& Powell (2011)- C36; (mod) Andrade et al. (2011)- C154- 156; (mod) Pol et al. (2012)- C36: Projeção ventral do processo posterolateral do squamosal: não fecha o meato auditivo posteriormente (0), fecha o meato auditivo posteriormente (1).

118. (mod) Sereno \& Larsson (2009)- C58: Projeção do processo posterolateral do squamosal: no mesmo nível to teto craniano (0), separado do teto craniano por um desnível (1).

119. (mod) Larsson \& Sues (2007)- C35; Sereno \& Larsson (2009)- C58; Turner \& Sertich (2010)- C168: Projeção do processo posterolateral do squamosal: não ornamentado (0), ornamentado (1).

120. Larsson \& Sues (2007)- C36; Sereno \& Larsson (2009)- C59; Projeção distal do processo posterolateral do squamosal: afilando (0), alargado (1). 
121. Ortega et al. (2000)- C62; Turner \& Sertich (2010)- C171; Pol \& Powell (2011)- C171; Pol et al. (2012)- C171: Supraoccipital: não exposto na superfície dorsal do crânio (0), exposto na superfície dorsal do crânio (1).

122. Montefeltro et al. (2011)- C37: Exposição dorsal do supraoccipital: exposto medianamente na região posterior do crânio (0), restrito a uma pequena faixa posterior ao parietal e squamosal (1).

123. (mod) Clark (1994)- C32; Turner \& Buckley (2008)- C285; Sereno \& Larsson (2009)C169; Turner \& Sertich (2010)- C285: Parietal: com uma ampla porção occipital (0), sem uma grande porção occipital (1).

124. Wilkinson et al. (2008)- C42; Young \& Andrade (2009)- C42; Young \& Andrade (2009)- C42; Young et al. (2011)- C42: Enclave na margem do parietal e squamosal em vista dorsal: ausente $(0)$, presente (1).

125. (mod) Andrade et al. (2011)- C150: Curvatura ventral do arco temporal: ausente (0), presente (1).

126. Ortega et al. (2000)- C10; Turner \& Sertich (2010)- C163; Pol \& Powell (2011)- C163; (mod) Andrade et al. (2011)- C382- 388; Pol et al. (2012)- C163: Posição relativa entre as margens ventrais da pré-maxila e maxilla: em linha (0), margem ventral da prémaxila ventral à margem ventral da maxilla (1).

127. Pol (1999)- C135- C50; (mod) Sereno \& Larsson (2009)- C80; Turner \& Sertich (2010)- C123; Pol \& Powell (2011)- C123; Andrade et al. (2011)- C35; Pol et al. (2011)- C123: Entalhe na margem lateral da pré-maxila formando a narina externa: ausente (0), presnte na metade dorsal da margem lateral da pré-maxila formando a narina externa (1). 
128. (mod) Pol \& Apesteguia (2005)- C221; Sereno \& Larsson (2009)- C82; Turner \& Sertich (2010)- C226; Pol \& Powell (2011)- C226; (mod) Andrade et al. (2011)- C40; Pol et al. (2012)- C226: Fossa perinarial: ausente (0), presente (1).

129. (mod) Pol \& Apesteguia (2005)- C221; Sereno \& Larsson (2009)- C82; Turner \& Sertich (2010)- C226; Pol \& Powell (2011)- C226; (mod) Andrade et al. (2011)- C40; Pol et al. (2012)- C226: Fossa perinarial: não alcançando a margem alveolar da prémaxila anteriormente (0), alcançando a margem alveolar da pré-maxila anteriormente (1).

130. (mod) Pol \& Apesteguia (2005)- C221; Sereno \& Larsson (2009)- C82; Turner \& Sertich (2010)- C226; Pol \& Powell (2011)- C226; (mod) Andrade et al. (2011)- C40; Pol et al. (2012)- C226: Fossa perinarial: não se estendendo posterior à margem posterior da narina externa (0), se estendendo posterior à margem posterior da narina externa (1).

131. (mod) Andrade \& Bertini (2008a)- C17; (mod) Andrade et al. (2011)- C23- 24: Distância entre os foramens neurovasculares da pré-maxila e maxila e respectivas margens alveolares: foramens neurovasculares separados da margem alveolar (0), foramens neurovasculares próximos à margem alveolar (1).

132. Andrade et al. (2011)- C25: Foramens neurovasculares da região media da maxila formando um arco: ausente, foramens alinhados em uma reta (0), presente (1).

133. (mod) Andrade \& Bertini (2008a)- C17; Andrade et al. (2011)- C26: Foramens neurovasculares da região posterior da maxila: foramens mais ventrais próximos à margem alveolar (0), foramens mais ventrais distantes da margem alveolar mais que duas vezes a distancia dos demais foramens (1).

134. Ortega et al. (2000)- C21; Turner \& Sertich (2010)- C183; (mod) Montefeltro et al. (2011)- C22; Pol \& Powell (2011)- C183; (mod) Andrade et al. (2011)- C318; Pol et al. 
(2011)- C183: Margem ventral da maxila em vista lateral: retilínea ou convexa (0), sinusoidal (1).

135. Pol (1999)- C149; Ortega et al. (2000)- C13; Jouve (2009)- C248; Turner \& Sertich (2010)- C135; Pol \& Powell (2011)- C135; Andrade et al. (2011)- C28; Pol et al. (2012)- C135: Forâmen presente na superfície da sutura pré-maxila-maxila, não relacionado a acomodação do dente mandibular hipertrofiado: ausente (0), presente (1).

136. Gasparini et al. (1991)- C3; Sereno \& Larsson (2009)- C102; Turner \& Sertich (2010)C213; Pol \& Powell (2011)- C213; Andrade et al. (2011)- C60- 61; Pol et al. (2012)C213: Processo anterior cuneiforme da maxila na região lateral da sutura pré-maxilamaxila: ausente (0), presente (1).

137. (mod) Pol (1999)- C153; Turner \& Sertich (2010)- C139; Pol \& Powell (2011)- C139; Andrade et al. (2011)- C54; Pol et al. (2012)- C153: Superfície externa da maxila e prémaxila: um único plano lateral (0), região ventral exposta lateralmente e região dorsal exposta laterodorsalmente (1).

138. (mod) Gasparini et al. (2006)- C236; (mod) Turner \& Sertich (2010)- C236; (mod) Pol \& Powell (2011)- C236; (mod) Pol et al. (2012)- C236: Margens alveolares evaginadas: ausente (0), presente (1).

139. (mod) Gasparini et al. (2006)- C236; (mod) Turner \& Sertich (2010)- C236; (mod) Pol \& Powell (2011)- C236; (mod) Pol et al. (2012)- C236: Margens alveolares evaginadas: formando uma estrutura continua (0), evaginações presentes em cada alvéolo (1).

140. (mod) Wu \& Sues (1996)- C29; Sereno \& Larsson (2009)- C104; Turner \& Sertich (2010)- C107; Pol \& Powell (2011)- C107; Pol et al. (2012)- C107: Região não esculpida ao longo da margem alveolar da maxila: ausente (0), presente (1).

141. (mod) Pol (1999)- C152; (mod) Sereno \& Larsson (2009)- C111; (mod) Turner \& Sertich (2010)- C138- 293; (mod) Pol \& Powell (2011)- C138; (mod) Pol et al. (2012)- 
C138: Foramens neurovasculares na região lateral da maxila: formando um linha continua (0), formando duas séries separadas por um intervalo (1).

142. (mod) Wu \& Chatterjee (1993)- C4; (mod) Wu et al. (1997)- C127; Sereno \& Larsson (2009)- C107: Extensão posterior da maxila na região lateral do rostro: posterior à margem anterior da órbita (0), anterior à margem anterior da órbita (1).

143. Zaher et al. (2006)- C193; Sereno \& Larsson (2009)- C25; Turner \& Sertich (2010)C229; Pol \& Powell (2011)- C229; Pol et al. (2012)- C229: Extensão posterior do lacrimal em relação ao jugal: estendendo-se posteroventralmente contatando amplamente o jugal (0), afilando posteroventralmente não contatando o jugal ou com um contato muito abreviado (1).

144. Larsson \& Sues (2007)- C26; Sereno \& Larsson (2009)- C39: Margem anterior do lacrimal e jugal: superficies confluentes sem um entalhe (0), margem anterior do jugal convexa formando um entalhe preenchido pela maxila no contato (1).

145. Pol (1999)- C134; Sereno \& Larsson (2009)- C43; Turner \& Sertich (2010)- C122; Pol \& Powell (2011)- C122; Andrade et al. (2011)- C181- 182; Pol et al. (2012)- C122: Extensão do jugal ventral à órbita: não excedendo a margem anterior da órbita (0), excedendo a margem anterior da órbita (1).

146. (mod) Brochu (1999)- C139; (mod) Larsson \& Sues (2007)- C22; (mod) Sereno \& Larsson (2009)- C35: Região orbital posterior do jugal: confluente com a barra pósorbital (0), deslocado lateralmente terminando anterior a barra pós-orbital e formando um entalhe (1).

147. (mod) Pol (1999)- C133; (mod) Ortega et al. (2000)- C145; (mod) Andrade \& Bertini (2008a)- C46; (mod) Sereno \& Larsson (2009)- C41; (mod) Turner \& Sertich (2010)C121; (mod) Montefeltro et al. (2011)- C27; (mod) Pol \& Powell (2011)- C121; (mod) 
Pol et al. (2012)- C121: Superfície lateral do jugal: confluente ao longo de toda a extensão (0), superfície infra-orbital deslocada lateralmente na região anterior (1).

148. (mod) Pol (1999)- C133; (mod) Ortega et al. (2000)- C145; (mod) Andrade \& Bertini (2008a)- C46; (mod) Sereno \& Larsson (2009)- C41; (mod) Turner \& Sertich (2010)C121; (mod) Montefeltro et al. (2011)- C27; (mod) Pol \& Powell (2011)- C121; (mod) Pol et al. (2012)- C121: Superfície deslocada lateralmente do jugal: não ultrapassando a margem anterior da órbita (0), ultrapassando a margem anterior da órbita (1).

149. Pol (1999)- C144; Turner \& Sertich (2010)- C130; Montefeltro et al. (2011)- C25; Pol \& Powell (2011)- C130; (mod) Andrade et al. (2011)- C178; Pol et al. (2012)- C130: Altura da região antero-orbital do jugal em relação à região infraorbital: alturas similares ou região infraorbital mais alta (0), região antero-orbital mais expandida que a região infraorbital (1).

150. (mod) Clark (1994)- C17; (mod) Turner \& Sertich (2010)- C17; Montefeltro et al. (2011)- C24; Pol \& Powell (2011)- C17; Andrade et al. (2011)- C174; (mod) Pol et al. (2012)- C17: Altura da região orbital do jugal em relação a altura da região infratemporal: alturas similares (0), região orbital duas vezes mais alta que a região infratemporal (1).

151. Zaher et al. (2006)- C194; Sereno \& Larsson (2009)- C45; Turner \& Sertich (2010)C230; Pol \& Powell (2011)- C230; (mod) Andrade et al. (2011)- C180; Pol et al. (2012)- C230: Superfície lateral do jugal próxima à margem anterior: sem um forâmen hipertrofiado (0), com um forâmen hipertrofiado (1).

152. Larsson \& Sues (2007)- C25; Sereno \& Larsson (2009)- C38: Tamanho relativo do processo anterior do jugal e o comprimento da fenestra temporal inferior: menor ou subigual (0), muito mais longo (1). 
153. (mod) Montefeltro et al. (2011)- C45: Sutura ectopterigóide-jugal: confluente (0), em uma crista bem marcada (1).

154. (mod) Montefeltro et al. (2011)- C45: Sutura ectopterigóide-jugal em formato de crista: contínua com a superfície infratemporal do jugal (0), separada da superfície infratemporal do jugal por um entalhe (1).

155. Sereno \& Larsson (2009)- C46; Andrade et al. (2011)- C177: Superfície posterior do jugal e ectopterigóide: sutura jugal ectopterigóide deslocado medialmente (0), superfícies laterais do jugal e ectopterigóide formando uma depressão (1).

156. Jouve (2004)- C68; Jouve (2009)- C75; Turner \& Sertich (2010)- C300: Lâmina ventral do jugal: estende longamente anterior ao ectopterigóide (0), extensão anterior em nível com a extensão anterior do ectopterigóide (1).

157. (mod) Pol (1999)- C156; Sereno \& Larsson (2009)- C142; Turner \& Sertich (2010)C142; Pol \& Powell (2011)- C142; (mod) Andrade et al. (2011)- C194; Pol et al. (2012)- C142: Orientação da base do processo pós-orbital do jugal: posterodorsalmente direcionada (0), dorsalmente direcionada (1), anterodorsalmente direcionada (2).

158. Pol (1999)- C157; Turner \& Sertich (2010)- C143; Pol \& Powell (2011)- C143; Pol et al. (2012)- C143: Localização do processo pós-orbital do jugal: disposto anteriormente no jugal (0), disposto na região média do jugal (1), disposto posteriormente no jugal (2).

159. Ortega et al. (2000)- C34; (mod) Turner \& Sertich (2010)- C167; (mod) Pol \& Powell (2011)- C167; (mod) Andrade et al. (2011)-C179- 193; (mod) Pol et al. (2012)- C167: Superfície lateral externa do processo pós-orbital do jugal: confluente com a superfície lateral do corpo do jugal (0), deslocada medialmente formando um sulco (1).

160. Ortega et al. (2000)-C34; (mod) Turner \& Sertich (2010)- C167; (mod) Pol \& Powell (2011)-C167; (mod) Andrade et al. (2011)-C179-193: Superfície lateral externa do processo pós-orbital do jugal deslocada medialmente: deslocada posteriormente, mas 
confluente com a superfície lateral do corpo do jugal anteriormente (0), deslocada medialmente por toda a extensão (1).

161. Clark (1994)- C18; Turner \& Sertich (2018)- C18; Montefeltro et al. (2011)- C28; Pol \& Powell (2011)- C18; Andrade et al. (2011)- C173; Pol et al. (2012)- C18: Processo infratemporal do jugal (0), lateromedialmente comprimida (0), sessão transversal circular (1).

162. (mod) Clark (1994)- C25; Sereno \& Larsson (2009)- C65; Turner \& Sertich (2010)C25; Pol \& Powell (2011)- C25; Andrade et al. (2011)- C13; Pol et al. (2012)- C25: Superfície externa da barra pós-orbital: ornamentada (0), não ornamentada (1).

163. Gasparini et al. (2006)- C244; Sereno \& Larsson (2009)- C77; Turner \& Sertich (2010)C244; Pol \& Powell (2011)- C244; Andrade et al. (2011)- C199; Pol et al. (2012)C244: Superfície lateral da barra pós-orbital: formada pelo pós-orbital e jugal (0), formada somente pelo pós-orbital (1).

164. (mod) Pol et al. (2004)- C179; (mod) Sereno \& Larsson (2009)- C44; (mod) Turner \& Buckley (2008)- C286; (mod) Turner \& Sertich (2010)- C210- 286; Pol \& Powell (2011)- C210; Andrade et al. (2011)- C176; Pol et al. (2012)- C210: Margem ventral da barra infratemporal: retilínea ou levemente arqueada dorsalmente (0), fortemente arqueada dorsalmente (1).

165. (mod) Pol \& Norell (2004b)- C183; (mod) Pol et al. (2009)- C216; (mod) Turner \& Sertich (2010)- C216; Pol \& Powell (2011)- C216; Pol et al. (2012)- C216: Crista na superfície infratemporal do jugal: ausente (0), presente (1).

166. Wu \& Sues (1996)- C14; Sereno \& Larsson (2009)- C40; Turner \& Sertich (2010)C102; Pol \& Powell (2011)- C102; Young et al. (2011)- C39: Andrade et al. (2011)C50- Pol et al. (2012)- C102- Jugal em elação a fossa antero-orbital: participando na margem da fossa antero-orbital (0), excluído da margem da fossa antero-orbital (1). 
167. Pol (1999)- C150; Sereno \& Larsson (2009)- C47; Turner \& Sertich (2010)- C136; (mod) Andrade et al. (2011)- C166; Pol et al. (2012)- C136: Processo posterior do jugal: estendendo posterior à margem posterior da fenestra infratemporal (0), não estendendo posterior à margem posterior da fenestra temporal inferior (1).

168. (mod) Pol (1999)- C155; (mod) Sereno \& Larsson (2009)- C51; (mod) Turner \& Sertich (2010)- C141; (mod) Pol \& Powell (2011)- C141; (mod) Pol et al. (2012)- C141: Quadradojugal alcançando o côndilo lateral do quadrado: não (0), sim (1).

169. (mod) Pol (1999)- C155; (mod) Sereno \& Larsson (2009)- C51; (mod) Turner \& Sertich (2010)- C141; (mod) Pol \& Powell (2011)- C141; (mod) Pol et al. (2012)- C141: Quadradojugal: alcança o côndilo do quadrado mas não participa da articulação crâniomandibular (0), participa da articulação crânio-mandibular (1).

170. (mod) Clark (1994)- C26; Sereno \& Larsson (2009)- C66; (mod)Turner \& Sertich (2010)- C26; Young et al. (2011)- C36; (mod) Pol \& Powell (2011)- C26; (mod) Andrade et al. (2011)- C191- 192; Pol et al. (2012)- C26: Formato da barra pós-orbital: comprimida lateromedialmente (0), muito robusta e com sessão transversal elíptica (1), delicada e com sessão transversal arredondada (2).

171. Clark (1994)- C29; Turner \& Sertich (2010)- C29; Pol \& Powell (2011)- C29; (mod) Andrade et al. (2011)- C123; Pol et al. (2012)- C29: Formato da região dorsal do pósorbital: com margens anterior e lateral apenas (0), com uma margem anterolateral adicional (1).

172. Clark (1994)- C30; Turner \& Sertich (2010)- C30; Pol \& Powell (2011)- C30; Young et al. (2011)- C90; Andrade et al. (2011)- C201; Pol et al. (2012)- C30: Região dorsal da superfície lateral da barra pós-orbital próximo ao teto craniano: confluente com o plano dorsal do pós-orbital (0), região dorsal da barra com constrição e não confluente com o plano dorsal do pós-orbital (1). 
173. Clark (1994)- C27; Turner \& Sertich (2010)- C27; Pol \& Powell (2011)- C27; Young et al. (2011)- C114; Andrade et al. (2011)- C202; Pol et al. (2012)- C27: Abertura vascular na região dorsal da barra pós-orbital: ausente (0), presente (1).

174. (mod) Larsson \& Sues (2007)- C39; Sereno \& Larsson (2009)- C67: Processo posteroventral do pós-orbital: ausente ou extremamente reduzido (0), presente e bem desenvolvido, margem dorsal da fenestra temporal inferior separada da margem dorsal do crânio (1).

175. (mod) Buscalioni et al. (1992)- C6; (mod) Brochu (1999)- C80; Wu et al. (1997)- C108; Sereno \& Larsson (2009)- C64; Turner \& Sertich (2010)- C199; Pol \& Powell (2011)C199; (mod) Andrade et al. (2011)- C204; Pol et al. (2012)- C199: Participação do pósorbital na fenestra temporal inferior: totalmente excluído, ou participação ínfima (0), bordejando a fenestra temporal inferior (1).

176. Montefeltro et al. (2011)- C15: Superfície do processo descendente do pós-orbital: plano (0), côncava (1).

177. Pol (1999)- C161; Sereno \& Larsson (2009)- C53; Turner \& Sertich (2010)- C145; Pol \& Powell (2011)- C145; Pol et al. (2012)- C145: Ornamentação na base do quadradojugal: ausente (0), presente (1).

178. (mod) Larsson \& Sues (2007)- C31; (mod) Pol \& Powell (2011)- C295; (mod) Pol et al. (2012)- C295: Comprimento do processo anterior do quadradojugal: ausente ou extremamente reduzido (0), presente (1).

179. Pol \& Norell (2004a)- C180; Turner \& Sertich (2010)- C211; Pol \& Powell (2011)C211; Pol et al. (2012)- C211: Região posterolateral do quadradojugal: afilando ou arredondada e fortemente associado ao quadrado (0), com a margem ventral sinusoidal e margem posterior ampla e arredondada e fracamente associado a margem lateral do quadrado (1). 
180. (mod) Clark (1994)- C19; (mod)Turner \& Sertich (2010)- C19; Montefeltro et al. (2011)- C14; Pol \& Powell (2011)- C19; Andrade et al. (2011)- C203; Pol et al. (2012)C19: Contato pós-orbital-quadradojugal em vista lateral: contato restrito ou ausente (0), contato amplo (1).

181. Pol \& Norell (2004b)- C185; Turner \& Sertich (2010)- C218; Pol \& Powell (2011)C218; Pol et al. (2012)- C218: Sessão dorsal da sutura entre quadradojugal e pósorbital: lisa (0), formando uma crista (1).

182. Ortega et al. (2000)- C47; (mod) Sereno \& Larsson (2009)- C49; Turner \& Sertich (2010)- C169; Pol \& Powell (2011)- C169; Young et al. (2011)- C133; Andrade et al. (2011)- C167; Pol et al. (2012)- C169: Margem posterior da fenestra temporal inferior: retilínea (0), com projeção anterior (1).

183. (mod) Sereno \& Larsson (2009)- C49: Projeção anterior da margem posterior da fenestra temporal inferior: em formato de crista (0), formando o spina-quadratojugalis (1).

184. Montefeltro et al. (2011)- C30: Margem ventral do quadradojugal e quadrado: contínua (0), margem ventral do esquamosal deslocada e marcando uma reentrância (1).

185. (mod) Turner \& Buckley (2008)- C288; (mod) Turner \& Sertich (2010)- C288:Processo anterior do squamosal recobrindo o pós-orbital anteriormente: ausente (0), presente (1).

186. (mod) Turner \& Buckley (2008)- C288; (mod) Turner \& Sertich (2010)- C288: Processo anterior do squamosal recobrindo o pós-orbital anteriormente: não alcançando a margem posterior da órbita (0), alcançando a margem posterior da órbita (1).

187. (mod) Pol (1999)- C166; (mod) Ortega et al. (2000)- C44; (mod) Sereno \& Larsson (2009)- C155; (mod) Turner \& Sertich (2010)- C149; (mod) Pol \& Powell (2011)C149; (mod) Andrade et al. (2011)- C291- 293: Pol et al. (2012)- C149- Orientação 
principal do eixo do quadrado: direcionado posteroventral (0), direcionado ventralmente ou anteroventralmente (1).

188. Clark (1994)- C47; Larsson \& Sues (2007)- C99; Sereno \& Larsson (2009)- C161; Turner \& Sertich (2010)- C47; Pol \& Powell (2011)- C47; Young et al. (2011)- C102; Andrade et al. (2011)- C298; Pol et al. (2012)- C47: Cabeça primária do quadrado: articula com squamosal, ottocipital e proótico (0), proótico e lateroesfenóide (1).

189. (mod) Montefeltro et al. (2011)- C33: Depressão lateral do quadrado: ausente (0), presente (1).

190. (mod) Brochu (1999)- C102; (mod) Larsson \& Sues (2007)- C95; (mod) Sereno \& Larsson (2009)- C157; (mod) Andrade et al. (2011)- C305: Abertura ótica da passage crânio-quadrada: não marcando uma reentrância na abertura ótica (0), marcando uma reentrância na abertura ótica (1), marcando um sulco posteroventral (2).

191. Clark (1994)- C46; Sereno \& Larsson (2009)- C156; Turner \& Sertich (2010)- C46; Pol \& Powell (2011)- C46; Andrade et al. (2011)- C297; Pol et al. (2012)- C46: Margem posterior do quadrado: largo medial ao tímpano e fracamente côncavo (0), margem posterior reduzida dorsal ao contato com o otoccipital e fortemente côncavo (1).

192. (mod) Larsson \& Sues (2007)- C41; Sereno \& Larsson (2009)- C69: Meato auditivo externo: contínuo (0), separado em duas regiões pela crista da sutura quadrado/quadradojugal (1).

193. (mod) Clark (1994)- C45; (mod) Larsson \& Sues (2007)- C98; (mod) Sereno \& Larsson (2009)- C160; (mod) Turner \& Sertich (2010)- C45; (mod) Pol \& Powell (2011)- C45; Young et al. (2011)- C158; (mod) Andrade et al. (2011)- C294- 295; (mod) Pol et al. (2012)- C45: Aberturas extras à abertura ótica do quadrado: ausente (0), presente (1).

194. (mod) Clark (1994)- C45; (mod) Larsson \& Sues (2007)- C98; (mod) Sereno \& Larsson (2009)- C160; (mod) Turner \& Sertich (2010)- C45; (mod) Pol \& Powell (2011)- C45; 
Young et al. (2011)- C158; (mod) Andrade et al. (2011)- C294- 295; (mod) Pol et al. (2012)- C45: Aberturas extras à abertura ótica do quadrado: somente forâmen pré-ótico do sifão (0), múltiplas fenestras (1).

195. Montefeltro et al. (2011)- C34: Fenestras do quadrado: visíveis em vista lateral (0), internalizadas na abertura ótica (1).

196. (mod) Brochu (1999)- C132; Sereno \& Larsson (2009)- C157; (mod) Andrade et al. (2011)- C304: Contato entre squamosal e quadrado na abertura ótica: dorsal à abertura ótica da passagem crânio-quadrado (0), na altura da abertura ótica da passagem crânioquadrada (1).

197. Montefeltro et al. (2011)- C31: Região distal do corpo do quadrado: margem anterior orientada em um ângulo reto em relação ao quadradojugal (0), margem anterior do quadrado apresenta uma curvatura não acentuada em direção ao quadradojugal (1).

198. Pol (1999)- C167; (mod) Larsson \& Sues (2007)- C97; (mod) Sereno \& Larsson (2009)C154- 159; Turner \& Sertich (2010)- C150; Pol \& Powell (2011)- C150; (mod) Andrade et al. (2011)- C299; Pol et al. (2012)- C150: Região distal do quadrado: formando apenas um plano orientado poteriormente (0), com dois planos distintos, um plano orientado posteriormente, e um plano medial com o forâmen aëreum (1).

199. (mod) Larsson \& Sues (2007)- C62; (mod) Pol \& Powell (2011)- C285; (mod) Montefeltro et al. (2011)- C39; (mod) Andrade et al. (2011)- C65: Forâmen incisivo: presente (0), ausente (1).

200. Clark (1994)- C7; Turner \& Sertich (2010)- C7; Pol \& Powell (2011)- C7; (mod) Andrade et al. (2011)- C68; Pol et al. (2012)- C7: Ramos palatais das pré-maxilas: não se contatam posterior ao forâmen incisivo (0), contatam-se posteriormente ao longo do conato com as maxilas (1). 
201. (mod) Brochu (1999)- C153; Turner \& Sertich (2010)- C270; Pol \& Powell (2011)C270; Pol et al. (2012)- C270: Forâmen incisivo: situado longe do processo alveolar no nível do segundo e terceiro alvéolo (0), aproxima-se do processo alveolar (1).

202. (mod) Sereno et al. (2001)- C68; Turner \& Sertich (2010)- C239; Pol \& Powell (2011)C239; Andrade et al. (2011)- C387; Pol et al. (2012)- C239: Orientação da região anterior da margem alveolar da pré-maxila: vertical (0), posteroventralmente direcionada (1).

203. Clark (1994)- C10; (mod) Sereno \& Larsson (2009)- C105; Turner \& Sertich (2010)C10; Pol \& Powell (2011)- C10; Pol et al. (2012)- C10: Ramo posterior da maxila: não se contatam anterior ao palatino (0), contatam anterior ao palatino (1).

204. (mod) Sereno et al. (2001)- C67; (mod) Sereno \& Larsson (2009)- C94; (mod) Turner \& Sertich (2010)- C227; Pol \& Powell (2011)- C227; Pol et al. (2012)- C227: Depressões paramedianas na pré-maxila: ausente (0), presente (1).

205. Turner \& Buckley (2008)- C290; Turner \& Sertich (2010)- C290: Depressões proeminentes no palato no nível do sexto e sétimo dentes maxilares: ausente (0), presente (1).

206. (mod) Pol (1999)- C139; (mod) Ortega et al. (2000)- C9; (mod) Sereno \& Larsson (2009)- C91; (mod) Turner \& Sertich (2010)- C126; (mod) Pol \& Powell (2011)- C126; (mod) Andrade et al. (2011)- C217; Pol et al. (2012)- C126: Sutura entre pré-maxila e maxila medial a região alveolar em vista palatal: anteromedilmente direcionada (0), sinusoidal, posteromedialmente direcionada lateralmente e anteromedialmente direcionada medialmente (1), posteromedialmente direcionada (2), côncava, com concavidade direcionada anteriormente (3). 
207. Larsson \& Sues (2007)- C66; Sereno \& Larsson (2009)- C90; Pol \& Powell (2011)C286; Pol et al. (2012)- C286: Fossa na lateral do rostro escavando o ultimo dente prémaxilar: ausente (0), presente (1).

208. Larsson \& Sues (2007)- C60; Pol \& Powell (2011)- C284; Pol et al. (2012)- C284: Foramens nutrientes na superfície palatal do contato pré-maxila-maxila: muito reduzido ou ausente (0), presente e bem desenvolvidos (1).

209. Pol \& Powell (2011)- C291; Pol et al. (2012)- C291: Superfície rugosa na superfície palatal da maxila posterior ao ultimo dente: ausente (0), presente (1).

210. Gasparini et al. (2006)- C253; Sereno \& Larsson (2009)- C110; Turner \& Sertich (2010)- C253; Pol \& Powell (2011)- C253; Pol et al. (2012)- C253: Depressão longitudinal na superfície palatal da maxila e palatino: ausente (0), presente (1).

211. Ortega et al. (2000)- C2; Andrade et al. (2011)- C20: Ornamentações na superfície palatal da maxila: ausente (0), presente (1)

212. Montefeltro et al. (2011)- C23: Contato sagital das maxilas: superfície lisa (0), presença de uma série longitudinal de foramens (1).

213. (mod) Andrade \& Bertini (2008a)- C88; (mod) Novas et al. (2009)- C231; (mod) Andrade et al. (2011)- C214- 215: Participação da maxilla na margen anterior da fenestra suborbital: participa amplamente (0), participação reduzida (1).

214. Larsson \& Sues (2007)- C71; Sereno \& Larsson (2009)- C109: Torus sagital no ramo palatal das maxillas: ausente (0), presente (1)

215. (mod) Brochu (1999)- C91; (mod) Larsson \& Sues (2007); C91- (mod) Sereno \& Larsson (2009)- C147; (mod) Turner \& Sertich (2010)- C264; Pol \& Powell (2011)C264; (mod) Andrade et al. (2011)- C252- 253; Pol et al. (2012)- C264: Contato entre ectopterigóide e maxila: ectopterigóide confina a maxila (0), contato amplo separando o ectopterigóide da fileira dentária da maxila (1). 
216. (mod) Montefeltro et al. (2011)- C32: Extensão dorsal do quadradojugal em vista medial: não alcançando o nível da margem dorsal da fenestra temporal inferior (0), alcançando o nível da margem dorsal da fenestra temporal inferior (1).

217. (mod) Clark (1994)- C37; (mod) Larsson \& sues (2007)- C79; (mod) Sereno \& Larsson (2009)- C121; (mod) Turner \& Sertich (2010)- C37; (mod) Pol \& Powell (2011)- C37; Andrade et al. (2011)- C211- 212- 213; Pol et al. (2012)- C37: Processo palatal do palatino: ausente (0), presente (1).

218. (mod) Clark (1994)- C37; (mod) Larsson \& sues (2007)- C79; (mod) Sereno \& Larsson (2009)- C121; (mod) Turner \& Sertich (2010)- C37; (mod) Pol \& Powell (2011)- C37; Andrade et al. (2011)- C211- 212- 213; Pol et al. (2012)- C37: Processo palatal do palatino: não contatam medialmente (0), contatam inteiramente formando parte do palato secundário (1).

219. (mod) Brochu (1999)- C108; (mod)- Gasparini et al. (2006)- C243; (mod) Larsson \& Sues (2007)- C78; (mod) Wilkinson et al. (2008)- C6; (mod) Young \& Andrade (2009)C6; (mod) Sereno \& Larsson (2009)- C124; (mod) Turner \& Sertich (2010)- C243; (mod) Pol \& Powell (2011)- C243; (mod) Young et al. (2011)- C6; (mod) Andrade et al. (2011)- C225- 226; Pol et al. (2012)- C243: Sutura palatino/maxila: palatino arredondado anteriormente (0), palatino afilando anteriormente (1), palatino invaginado (2), sutura transversal em relação ao eixo sagittal do crânio (3).

220. (mod) Andrade \& Bertini (2008a)- C88; (mod) Andrade et al. (2011)- C216; Processo maxilar do palatino próximo a fenestra suborbital: ausente (0), presente (1).

221. Andrade et al. (2011)- C229: Largura do duto nasofaringeal em sua menor largura: restrito, não mais que $25 \%$ da largura total do crânio (0), largo, não menos que $50 \%$ da largura total do crânio (1). 
222. Pol (1999)- C143; Turner \& Sertich (2010)- C129; Montefeltro et al. (2011)- C40; Pol \& Powell (2011)- C129; Andrade et al. (2011)- C222; Pol et al. (2012)- C129: Extensão anterior do palatino: ultrapassando a margem anterior da fenestra suborbital (0), não ultrapassando a margem anterior da fenestra suborbital (1).

223. (mod) Wu et al. (1997)- C128; Larsson \& Sues (2007)- C80; Andrade \& Bertini (2008a)- C85; Sereno \& Larsson (2009)- C128; Pol et al. (2009)- C208; Turner \& Sertich (2010)- C208; Pol \& Powell (2011)-C208; (mod) Andrade et al. (2011)- C205; Pol et al. (2012)- C208: Fenestras palatais anteriores: ausentes (0), presentes (1).

224. Montefeltro et al. (2011)- C42; (mod) Andrade et al. (2011)- C232: Contato sagittal entre os palatinos: liso (0), rugoso (1).

225. Montefeltro et al. (2011)- C44: Fileira de foramens flanqueando o contato medial dos palatinos: ausente (0), presente (1).

226. Pol et al. (2009)- C278; Turner \& Sertich (2010)- C278; Pol \& Powell (2011)- C278; Pol et al. (2012)- C278: Região anterior da barra entre as fenestras suborbitais: margens laterais paralelas ou subparalelas (0), margens laterais divergindo anteriormente (1).

227. Pol et al. (2009)- C279; Turner \& Sertich (2010)- C279; Pol \& Powell (2011)- C279; Pol et al. (2012)- C279: Região posterior da barra entre as fenestras suborbitais: margens laterais paralelas ou subparalelas (0), margens laterais divergindo posteriormente (1).

228. (mod) Montefeltro et al. (2011)- C41; (mod) Andrade et al. (2011)- C231: Face ventral da barra palatina: plana e larga (0), superfície ventral restrita e região dorsal cilíndrica (1).

229. (mod) Montefeltro et al. (2011)- C41; (mod) Andrade et al. (2011)- C231: Região dorsal cilíndrica da barra palatina: com a mesma largura em toda extensão (0), com uma constrição na região posterior (1). 
230. (mod) Martinelli (2003)- C36; Zaher et al. (2006)- C196; Sereno \& Larsson (2009)C129; (mod) Turner (2004)- C119; (mod) Turner \& Sertich (2010)- C232; (mod) Pol \& Powell (2011)- C232; (mod) Andrade et al. (2011)- C228- 259; Pol et al. (2012)- C232: Eixo anteroposterior do palatino: paralelo ao longo de todo o comprimento (0), expandindo lateroposteriormente em um processo de sessão transversal arredondada (1).

231. Pol \& Norell (2004a)- C165; Sereno \& Larsson (2009)- C125; Turner \& Sertich (2010)C194; Pol \& Powell (2011)- C194; Pol et al. (2012)- C194: Contato entre palatino e pterigóide: palatino recobre pterigóide (0), palatino fortemente suturado ao pterigóide (1).

232. Buckley et al. (2000)- C115; Sereno \& Larsson (2009)- C120; Turner \& Sertich (2010)C284; Andrade et al. (2011)-C221: Vomer: exposto no palato (0), não exposto no palato (1).

233. Clark (1994)- C38; Turner \& Sertich (2010)- C38; Pol \& Powell (2011)- C38; Pol et al. (2012)- C38: Pterigoide: sobrepondo o quadrado e o basiesfenóide (0), fortemente suturado ao quadrado e ao lateroesfenóide (1).

234. Wu et al. (1997)- C121; Turner \& Sertich (2010)- C204; Pol \& Powell (2011)- C204; Pol et al. (2012)- C204: Contato entre os pterigóides no palato: ausência de contato anterior ao basiesfenóide (0), em contato anterior ao basiesfenóide (1).

235. (mod) Clark (1994)- C43; (mod) Sereno \& Larsson (2009)- C126; Turner \& Sertich (2010)- C43; Pol \& Powell (2011)- C43; (mod) Andrade et al. (2011)- C242- 243; Pol et al. (2012)- C43: Palato pterigoidano primário: forma a margem posterior da coana (0), forma a margem posterior, lateral e parte da margem anterior da coana (1), forma a coana completamente (2).

236. Andrade \& Bertini (2008a)- C103; Turner \& Sertich (2010)- C291; (mod) Montefeltro et al. (2011)- C50; (mod) Pol et al. (2011)- C293; Andrade et al. (2011)- C209; (mod) 
Pol et al. (2012)- C293: Fossas paracoanais na superfície ventral do pterigoide: ausente (0), presente (1).

237. (mod) Montefeltro et al. (2011)- C50; (mod) Pol et al. (2011)- C293; (mod) Pol et al. (2012)- C293: Fenestras paracoanais do pterigoide: ausente (0), presente (1).

238. (mod) Montefeltro et al. (2011)- C50; (mod) Pol et al. (2011)- C293; (mod) Pol et al. (2012)- C293: Fenestras paracoanais do pterigoide: abertas dorsalmente (0), fechadas dorsalmente (1).

239. Turner \& Sertich (2010)- C292: Pterigoide formando a margem da fenestra suborbital: presente (0), ausente (1).

240. (mod) Clark (1994)- C44; Sereno \& Larsson (2009)- C136; Turner \& Sertich (2010)C44; (mod) Pol \& Powell (2011)- C44; (mod) Andrade et al. (2011)- C235- 236- 237; Pol et al. (2012)- C44: Margem anterior da coana: localizada entre as fenestras suborbitais ou anteriormente (0), próximo a margem posterior das fenestras suborbitais (1), próxima à margem posterior da asa do pterigoide (2).

241. (mod) Andrade et al. (2011)- C262: Crista na superfície ventral da região proximal do pterigoide: ausente (0), presente (1)

242. (mod) Andrade et al. (2011)- C262: Crista na superfície ventral da região proximal do pterigoide: restrita (0), robusta (1).

243. Pol (1999)- C165; Sereno \& Larsson (2009)- C137; Turner \& Sertich (2010)- C148; Pol \& Powell (2011)- C148; Pol et al. (2012)- C148: Processo quadrado do pterigoide: bem desenvolvido (0), pouco desenvolvido (1).

244. (mod) Wu et al. (1997)- C119; Turner \& Sertich (2010)- C203; Pol \& Powell (2011)C203; Pol et al. (2012)- C203: Largura do ramo quadrado do pterigoide em vista ventral: estreito (0), largo (1). 
245. Clark (1994)- C40; Turner \& Sertich (2010)- C40; Pol \& Powell (2011)- C40; Pol \& Powell (2011)- C40; Andrade et al. (2011)- C21; Pol et al. (2012)- C40: Superfície palatal do pterigoide: sem ornamentações (0), ornamentada (1).

246. (mod) Ortega et al. (2000)- C138; (mod) Sereno \& Larsson (2009)- C138; Turner \& Sertich (2010)- C179; (mod) Pol \& Powell (2011)- C179; (mod) Andrade et al. (2011)C261- 263; Pol et al. (2012)- C179: Asa do pterigoide: laminar (0), com sessão transversal arredondada (1).

247. (mod) Ortega et al. (2000)- C138; (mod) Sereno \& Larsson (2009)- C138; Turner \& Sertich (2010)- C179; (mod) Pol \& Powell (2011)- C179; (mod) Andrade et al. (2011)C261- 263; Pol et al. (2012)- C179: Comprimento da asa do pterigoide com sessão transversal arredondada: alongada (0), restrita (1).

248. Wu et al. (1997)- C106; Turner \& Sertich (2010)- C198; Pol \& Powell (2011)- C198; Pol et al. (2012)- C198: Asa do pterigoide: laminar e fina (0), robusta com espaços pneumáticos (1).

249. Osi et al. (2007)- C166; Buscalioni et al. (2011)-C180; Expansão lateral da asa do pterigoide: expandida ultrapassando o nível do côndilo medial do quadrado (0), reduzida lateralmente não alcançando o nível do côndilo medial do quadrado (1).

250. (mod) Larsson \& Sues (2007)- C83; (mod) Sereno \& Larsson (2009)- C130: Processo posterior do pterigoide: ausente (0), bem desenvolvido e se projetando posteriormente (1).

251. (mod) Pol \& Apesteguia (2005)- C186; (mod) Turner \& Sertich (2010)- C191; (mod) Pol \& Powell (2011)- C191; Andrade et al. (2011)- C247; Pol et al. (2012)- C191: Septo coanal: estrutura laminar vertical (0), uma barra expandida ventralmente (1), robusto e arredondado em sessão transversal (2). 
252. (mod) Turner (2006)- C126; (mod) Sereno \& Larsson (2009)- C271; (mod) Pol et al. (2009)- C271; (mod) Turner \& Sertich (2010)- C271; (mod) Montefeltro et al. (2011)C47; (mod) Pol \& Powell (2011)- C271; (mod) Andrade et al. (2011)- C246; (mod) Pol et al. (2012)- C246: Superfície ventral do septo coanal: plano (0), marcado por um sulco (1), com uma crista (2).

253. Pol (1999)- C158; Ortega et al. (2000)- C36; Sereno \& Larsson (2009)- C76; Turner \& Sertich (2010)- C144; Pol \& Powell (2011)- C144; Andrade et al. (2011)- C198; Pol et al. (2012)- C144: Contato entre pós-orbital e ectopterigóide: presente (0), ausente (1).

254. Sereno \& Larsson (2009)- C148; Andrade et al. (2011)- C197: Ectopterigóide participando da região ventral da barra pós-orbital: ausente (0), presente (1).

255. Pol et al. (2004)- C164; Turner \& Sertich (2010)- C195; Pol \& Powell (2011)- C195; Pol et al. (2012)- C195: Orientação do eixo principal do ectopterigóide: lateral ou ligeiramente anterolateral (0), subparalelo ao eixo sagital do crânio (1).

256. Zaher et al. (2006)- C198; Sereno \& Larsson (2009)- C145; Turner \& Sertich (2010)C235; Pol \& Powell (2011)- C235; Pol et al. (2012)- C235: Extensão da projeção medial do ectopterigóide sobre a asa do pterigóide: estende-se pouco (0), bem estendido, ocupando aproximadamente a metade lateral da superfície ventral da asa do pterigóide (1).

257. (mod) Norell (1988)- C32; Brochu (1999)- C149; Turner \& Sertich (2010)- C269; Pol \& Powell (2011)- C269; Andrade et al. (2011)- C257; Pol et al. (2012)- C269: Extensão distal do ectopterigoide sobre a asa do pterigoide: alcança a região mais distal da asa do pterigóide (0), não alcança a região mais distal da asa do pterigoide (1).

258. Zaher et al. (2006)- C197; Turner \& Sertich (2010)- C233; Pol \& Powell (2011)- C233; (mod) Andrade et al. (2011)- C255; Pol et al. (2012)- C233: Participação do ectopterigóide na barra palatina: ausente (0), presente (1). 
259. Pol (1999)- C147; Turner \& Sertich (2010)- C133; Pol \& Powell (2011)- C133; Pol et al. (2012)- C133: Processo anterior do ectopterigóide: bem desenvolvido (0), reduzido (1).

260. Ortega et al. (2000)- C146; Sereno \& Larsson (2009)- C146; Turner \& Sertich (2010)C180; Pol \& Powell (2011)- C180; Andrade et al. (2011)- C254; Pol et al. (2012)C180: Processo medial do ectopterigóide: simples (0), bifurcado (1).

261. Pol (1999)- C148; (mod) Larsson \& Sues (2007)- C94; (mod) Sereno \& Larsson (2009)C150; Turner \& Sertich (2010)- C134; Pol \& Powell (2011)- C134; Pol et al. (2012)C134: Processo posterior do ectopterigóide: bem desenvolvido (0), reduzido (1).

262. Pol \& Powell (2011)- C292; Pol et al. (2012)- C292: Contato ectopterigóide/palatino posterior à fenestra suborbital: ausente (1), presente (1).

263. Andrade et al. (2011)- C256: Morfologia do ramo distal do ectopterigóide: laminar (0), com sessão transversal arredondada em maior parte de sua extensão (1).

264. Clark (1994)- C54; Turner \& Sertich (2010)- C54; Pol \& Powell (2011)- C54; Andrade et al. (2011)- C289; Pol et al. (2012)- C54: Formato do processo basipterigóide: proeminente formando uma sutura móvel com o pterigóide (0), basisfenóide suturalmente fechado (1).

265. Clark (1994)- C56; (mod) Larsson \& Sues (2007)- C89- 90; Sereno \& Larsson (2009)C131- 135; Turner \& Sertich (2010)- C56; Pol \& Powell (2011)- C56; Young et al. (2011)- C87; (mod) Andrade et al. (2011)- C286; Pol et al. (2012)- C56: Basisfenóide na face ventral do neuro-crânio: exposto (0), praticamente não exposto em vista ventral (1).

266. Pol (1999)- C163; Sereno \& Larsson (2009)- C174; Turner \& Sertich (2010)- C147; Pol \& Powell (2011)- C147; Pol et al. (2012)- C147: Exposição lateral do basisfenóide no neuro-crânio: ausente (0), presente (1). 
267. Montefeltro et al. (2011)- C51: Superfície ventral do basisfenóide: confluente com a superfície dos ossos adjacentes (0), corpo central do basisfenóide ventralmente desenvolvido e separado da superfície dos ossos adjacentes por um sulco e formando uma tuberosidade pós-coanal do pterigóide e basisfenóide (1).

268. Clark (1994)- C50; Turner \& Sertich (2010)- C50; Pol \& Powell (2011)- C50; Pol et al. (2012)- C50: Superfície ventral do ramo quadrado do pterigóide: plano (0), com um $\operatorname{sulco}(1)$.

269. Pol \& Norell (2004a)- C170; Turner \& Sertich (2010)- C209; (mod) Montefeltro et al. (2011)- C54; Pol \& Powell (2011)- C170; Pol et al. (2012)- C170: Par de cristas na superfície ventral do basisfenóide: ausente (0), presente (1).

270. (mod) Wu et al. (1997)- C104; Larsson \& Sues (2007)- C100; (mod) Sereno \& Larsson (2009)- C162: Contato basisfenóide-quadrado: contato dorsolateral (0), contato dorsolateral e anterolateral (1).

271. (mod) Clark (1994)- C55; Ortega et al. (2000)- C68; (mod) Larsson \& Sues (2007)C90; Sereno \& Larsson (2009)- C131; Turner \& Sertich (2010)- C55; Pol \& Powell (2011)- C55; (mod) Andrade et al. (2011)- C286; Pol et al. (2012)- C55: Comprimento do basisfenóide em relação ao comprimento do basioccipital em vista ventral: basisfenóide mais curto que o basioccipital (0), basisfenóide mais longo que o basioccipital (1).

272. Clark (1994)- C57; Larsson \& Sues (2007)- C110; Sereno \& Larsson (2009)- C177; Turner \& Sertich (2010)- C57; Pol \& Powell (2011)- C57; (mod) Andrade et al. (2011)C268- 288; Pol et al. (2012)- C57: Basal tubera do basioccipital: reduzidos (0), bem desenvolvidos ventralmente (1).

273. Turner \& Sertich (2010)- C297: Crista medial na superfície ventral do basioccipital anterior ao côndilo occipital: ausente (0), presente (1). 
274. Clark (1994)- C52; Turner \& Sertich (2010)- C52; Pol \& Powell (2011)- C52; Andrade et al. (2011)- C290; Pol et al. (2012)- C52: Tubos eustaquianos: não completamente incluídos entre o basioccipital e basisfenóide (0), completamente incluídos entre o basioccipital e basisfenóide (1).

275. Pol (1999)- C146; Sereno \& Larsson (2009)- C173; Turner \& Sertich (2010)- C132; Pol \& Powell (2011)- C132; Pol et al. (2012)- C132: Localização das aberturas dos tubos eustaquianos laterais: localizadas posteriores à abertura do tubo eustaquiano medial (0), alinhadas anteroposteriormente e dorsoventralmente à abertura do tubo eustaquiano medial (1).

276. Montefeltro et al. (2011)- C52: Parede anterior das aberturas dos tubos eustaquianos laterais: presente (0), ausente, aberturas abrem em um sulco anterior (1).

277. Montefeltro et al. (2011)- C53: Tamanho da abertura dos tubo eustaquiano medial: maior que as aberturas dos tubos laterais (0), menor que a abertura dos tubos laterais (1).

278. Montefeltro et al. (2011)- C29: Ramo anterior do quadrado em vista anterior: formando mais que $50 \%$ da margem lateral da fenestra temporal superior interna (0), formando menos que $50 \%$ da margem lateral da fenestra temporal superior interna (1).

279. Montefeltro et al. (2011)- C36: Cicratriz muscular correspondente à crista 'A' (Iordansky 1968): reta, ou curvada (0), sigmoidal (1).

280. Osi et al. (2007)- C165; (mod) Buscalioni et al. (2011)- C178: Cicratriz muscular correspondente à crista 'A' (Iordansky, 1968): simples (0), composta por várias cristas (1).

281. Pol \& Norell (2004a)- C164; Sereno \& Larsson (2009)- C152; Turner \& Sertich (2010)C192; Pol \& Powell (2011)- C192: Sessão transversal do ramo distal do quadrado: desenvolvido mediolateral e restrito anteroposteriormente (0), subquadrangular (1). 
282. (mod) Ortega et al. (2000)- C53; Sereno \& Larsson (2009)- C153; Turner \& Sertich (2010)- C170; Pol \& Powell (2011)- C170; Andrade et al. (2011)- C300; Pol et al. (2012)- C170: Sulco entre os côndilos do quadrado: pouco desenvolvido (0), profunda, com côndilo medial bem desenvolvido (1).

283. Montefeltro et al. (2011)- C35: Côndilo lateral do quadrado: mesmo comprimento anteroposterior que o côndilo medial (0), côndilo lateral hemisférico (1).

284. Brochu (1999)- C115; Larsson \& Sues (2007)- C103; Sereno \& Larsson (2009)- C165: Ponte do lateroesfenóide: ausente (0), presente, parcial ou completo (1).

285. Brochu (1999)- C130; Sereno \& Larsson (2009)- C175; Turner \& Sertich (2010)- C267; Pol \& Powell (2011)- C267; Andrade et al. (2011)- C285; Pol et al. (2012)- C285: Processo capitate do lateroesfenóide: lateralmente orientado (0), voltado medialmente ao plano sagital do crânio (1).

286. Gasparini et al. (2006)- C249; Sereno \& Larsson (2009)- C61; Turner \& Sertich (2010)C249; Pol \& Powell (2011)- C249; Pol et al. (2012)- C249: Região posterolateral do squamosal lateral ao processo paroccipital: reduzido (0), com uma superfície arredondada (1).

287. Clark (1994)- C62; Turner \& Sertich (2010)- C62; Pol \& Powell (2011)- C62; Andrade et al. (2011)- C270; Pol et al. (2012)- C62: Supraoccipital: formando parte da margem dorsal do foramen magnum (0), excluído da margem dorsal do foramen magnum pelo contato medial entre os processos paraoccipitais (1).

288. Clark (1994)- C64; Sereno \& Larsson (2009)- C176; Turner \& Sertich (2010)- C64; Pol \& Powell (2011)- C64; (mod) Andrade et al. (2011)- C266; Pol et al. (2012)- C64: Superfície posterior do supraoccipital: plana (0), com protuberâncias bilaterais desenvolvidas (1). 
289. Andrade et al. (2011)- C267: Concavidade na superfície posterior do supraoccipital: ausente (0), presente (1).

290. Jouve et al. (2005)- C5; Andrade et al. (2011)- C272: Participação do exoccipital no côndilo occipital: ausente (0), presente (1).

291. (mod) Gomani (1997)- C32; Sereno \& Larsson (2009)- C172; Turner \& Sertich (2010)C112; Pol \& Powell (2011)- C112; Pol et al. (2012)- C112: Orientação da superfície posterior do basioccipital e parte ventral do otoccipital: orientada posteriormente (0), orientada posteroventralmente (1).

292. Clark (1994)- C48; Turner \& Sertich (2010)- C48; Pol \& Powell (2011)- C48; Andrade et al. (2011)- C274; Pol et al. (2012)- C48: Contato ventrolateral entre otoccipital e quadrado: reduzido (0), amplo (1).

293. Young \& Andrade (2009)- C7: Orientação do processo paraoccipital em vista occipital: horizontal (0), dorsolateralmente direcionado em um ângulo de $45^{\circ}(1)$, região medial retilínea e região lateral inclinada dorsalmente em um ângulo $45^{\circ}$ (2), curvado fortemente ventralmente (3).

294. Clark (1994)- C58; Turner \& Sertich (2010)- C58; Pol \& Powell (2011)- C58; Andrade et al. (2011)- C273; Pol et al. (2012)- C58: Processo côncavo descendente do otoccipital ventral ao processo sub-escaplar: ausente (0), presente (1).

295. Clark (1994)- C51; Turner \& Sertich (2010)- C51; Pol \& Powell (2011)- C51; Andrade et al. (2011)- C275; Pol et al. (2012)- C51: Contato entre a região ventromedial do quadrado e otoccipital: ausente (0), presente, formando a artéria carótida e nervos IX-XI (1).

296. Clark (1994)- C59; Turner \& Sertich (2010)- C59; Pol \& Powell (2011)- C59; Andrade et al. (2011)- C276; Pol et al. (2012)- C59: Passagem dos nervos cranianos IX-XI no 
neuro-crânio: saída comum através de um forâmen vago no otoccipital (0), saída do nervo IX medial à saída dos nervos X e XI (1).

297. (mod) Wu et al. (1997)- C105; Larsson \& Sues (2007)- C101; Sereno \& Larsson (2009)- C163; Turner \& Sertich (2010)- C197; Pol \& Powell (2011)- C197; Pol et al. (2012)- C197: Contato ventromedial do corpo do quadrado com o otoccipital: distinto (0), indistinto (1).

298. Clark (1994)- C60; Sereno \& Larsson (2009)- C168; Turner \& Sertich (2010)- C60; Pol \& Powell (2011)- C60; Andrade et al. (2011)- C269; Pol et al. (2012)- C60: Otoccipital ventral ao processo paroccipital bem desenvolvido: ausente (0), presente (1).

299. Clark (1994)- C61; Turner \& Sertich (2010)- C61; Pol \& Powell (2011)- C61; Andrade et al. (2011)- C281; Pol et al. (2012)- C61: Orientação da crista interfenestralis entre a fenestra pseudorotunda e fenestra ovalis: vertical (0), horizontal (1).

300. Clark (1994)- C63; Sereno \& Larsson (2009)- C170; Turner \& Sertich (2010)- C63; Pol \& Powell (2011)- C63; Andrade et al. (2011)- C282; Pol et al. (2012)- C63: Localização do antro mastoideo: não se estende ao supraoccipital (0), se estende ao supraoccipital em um canal transversal que conecta à região do ouvido médio (1).

301. Pol \& Norell (2004a)- C181; Sereno \& Larsson (2009)- C151; Turner \& Sertich (2010)C212; Pol \& Powell (2011)- C212; Pol et al. (2012)- C212: Orientação do contato otoccipital-quadrado em vista posterior: vental (0), ventrolateral (1).

302. Gasparini et al. (2006)- C248; Turner \& Sertich (2010)- C248; Pol \& Powell (2011)C248; Pol et al. (2012)- C248: Tamanho do forâmen da carótida interna: reduzido, similar ao tamanho das aberturas cranianas dos nervos IX-XI (0), muito maior que as aberturas cranianas dos nervos IX-XI (1).

303. (mod) Montefeltro et al. (2011)- C60: Superfície da região sinfiseal: não ornamentada (0), ornamentada (1). 
304. (mod) Montefeltro et al. (2011)- C60: Ornamentação da superfície da região sinfesial: somente dentário ornamentado (0), dentário e esplenial ornamentados (1).

305. (mod) Andrade et al. (2011)- C17- 18: Superfície da região posterior da mandíbular (angular, metade posterior do supra-angular e angular): superfície pouco ornamentada (0), fortemente ornamentada com um padrão particular de ornamentação irradiando da região ventral (1).

306. Clark (1994)- C75; (mod) Sereno \& Larsson (2009)- C185; Turner \& Sertich (2010)C75; Young et al. (2011)- C45; Pol \& Powell (2011)- C75; (mod) Andrade et al. (2011)- C312; Pol et al. (2012)- C75: Fenestra mandibular: ausente (0), presente (1).

307. (mod) Clark (1994)- C75; (mod) Sereno \& Larsson (2009)- C185; (mod) Turner \& Sertich (2010)- C75; Pol \& Powell (2011)- C75; (mod) Young et al. (2011)- C45; (mod) Andrade et al. (2011)- C313; Pol et al. (2012)- C75: Tamanho da fenestra mandibular: tamanho reduzida (0), tamanho avantajado (1).

308. Andrade et al. (2011)- C314: Orientação do eixo principal da fenestra mandibular: horizontal (0), inclinado anteroventalmente (1).

309. Andrade et al. (2011)- C315- 316- 339: Formato da fenestra mandibular externa: subcircular à levemente elíptica (0), fortemente elíptica, eixo anterior-posterior pelo menos três vezes mais longo que eixo dorsal-ventral (1), em formato de fenda (2), formato de gota (3), triangular (4).

310. Andrade et al. (2011)- C321: Morfologia do ramo distal da mandibular em vista oclusal: ramo distal retilíneo ou levemente curvado (0), ramo distal fortemente curvado conferindo a mandibular um formato de "Y" (1).

311. Wu et al. (1997)- C112; Turner \& Sertich (2010)- C202; Pol \& Powell (2011)- C202; Pol et al. (2012)- C202: Margem posteroventral do ramo mandibular: retilíneo ou convexo (0), fortemente deslocado ventralmente (1). 
312. Wu \& Sues (1996)- C23; Larsson \& Sues (2007)- C102; Sereno \& Larsson (2009)C164; (mod) Turner \& Sertich (2010)- C105; Pol \& Powell (2011)- C105; (mod) Andrade et al. (2011)- C02-03-04; Pol et al. (2012)- C105: Articulação da mandibular: no mesmo nível que o côndilo occipital (0), ventralmente posicionada em relação ao côndilo occipital (1).

313. Ortega et al. (2000)- C90; Turner \& Sertich (2010)- C174; Montefeltro et al. (2011)C61; Pol \& Powell (2011)- C174; Pol et al. (2012)- C174: Tamanho do forâmen intramandibularis oralis: reduzido (0), muito grande (1).

314. (mod) Larsson \& Sues (2007)- C119; (mod) Sereno \& Larsson (2009)- C185: Forâmen intramandibularis caudalis: ausente (0), presente (1).

315. (mod) Buckley \& Brochu (1999)- C105; Sereno \& Larsson (2009)- C189; Turner \& Sertich (2010)- C158; Pol \& Powell (2011)- C158; (mod) Andrade et al. (2011)- C337: Superfície lateral do dentário no nível do sétimo dente: plana (0), com uma concavidade para a recepção de um dente canineforme da maxila (1).

316. Pol \& Apesteguia (2005)- C188; Sereno \& Larsson (2009)- C194; Turner \& Sertich (2010)- C193; Pol \& Powell (2011)- C193; Pol et al. (2012)- C193: Superfície lateral do dentário ventral à margem alveolar mediana e posterior: orientada verticalmente contínua com o restante da superfície lateral do dentário (0), superfície plana exposta dorsolateralmente e separada do restante da superfície do dentário por uma crista (1).

317. Clark (1994)- C70; Sereno \& Larsson (2009)- C181; Turner \& Sertich (2010)- C70; Pol \& Powell (2011)- C70; (mod) Andrade et al. (2011)- C338; Pol et al. (2012)- C70: Dentário estendido posteriormente ventral à fenestra mandibular externa: presente (0), ausente (1).

318. (mod) Ortega et al. (1996)- C2; (mod) Buckley \& Brochu (1999)- C108; Sereno \& Larsson (2009)- C192; Turner \& Sertich (2010)- C160; Pol \& Powell (2011)- C160; Pol 
et al. (2012)- C160: Compressão do dentário na região lateroventral anterior à fenestra mandibular: presente (0), ausente, superfície convexa (1).

319. Pol (1999)- C213; Turner \& Sertich (2010)- C155; Pol \& Powell (2011)- C155; Pol et al. (2012)- C155: Dentário com região não ornamentada ventral à linha de dentes: ausente (0), presente (1).

320. (mod) Ortega et al. (1996)- C1; Sereno \& Larsson (2009)- C190; (mod) Buckley \& Brochu (1999)- C107; Turner \& Sertich (2010)- C159; Pol \& Powell (2011)- C159; Pol et al. (2012)- C159: Margem dorsal do dentário: ligeiramente côncava ou retilínea, subparalela ao eixo do crânio (0), retilínea com uma expansão abrupta (1), retilínea com uma expansão abrupta e côncava posterior a expansão (2), sinusoidal, com duas concavidades (3).

321. Brochu (1999)- C48; Sereno \& Larsson (2009)- C196; Turner \& Buckley (2008)- C289; Turner \& Sertich (2010)- C289; (mod) Andrade et al. (2011)- C347-348-349: Sutura do dentário e supra-angular: simples (0), complexa, com três projeções posteriores do dentário e duas projeções anteriores do supra-angular (1).

322. (mod) Brochu (1999)- C53; Turner \& Sertich (2010)- C262; Pol \& Powell (2011)C262; (mod) Andrade et al. (2011)- C401; Pol et al. (2012)- C262: Projeção dos alvéolos anteriores do dentário: anterodorsal (0), procumbente (1).

323. (mod) Ortega et al. (2000)- C98; Sereno \& Larsson (2009)- C197; Turner \& Sertich (2010)- C175; Pol \& Powell (2011)- C175; Pol et al. (2012)- C175: Tamanho do coronoide: curto, localizado imediatamente à margem dorsal da mandibular (0), longo, se estendendo anteriormente e região posterior elevada dorsalmente à margem dorsal dos ramos mandibulares (1). 
324. Young \& Andrade (2009)- C157; Young et al. (2011)- C157; Young et al. (2012)C146: Participação do coronóide na superfície lateral da mandibular: ausente (0), presente (1)

325. Pol \& Apesteguia (2005)- C181; Sereno \& Larsson (2009)- C191; Turner \& Sertich (2010)- C186; Pol \& Powell (2011)- C186; Montefeltro et al. (2011)- C63; Andrade et al. (2011)- C335; Pol et al. (2012)- C186: Protuberância na superfície posterior da sínfise: ausente (0), presente (1).

326. Montefeltro et al. (2011)- C64: Depressões sinfiseais posteroventrais: ausente (0), presente (1).

327. (mod) Montefeltro et al. (2011)- C64: Depressões sinfiseais posteroventrais: voltadas ventralmente (0), voltadas posteriormente (1).

328. Andrade et al. (2011)- C332: Tamanho da sínfise: curta, tão longa quanto larga (0), relativamente longa, mais longa que larga (1), muito longa, comprimento cinco vezes maior que largura (2).

329. (mod) Clark (1994)- C77; Sereno \& Larsson (2009)- C188; (mod) Turner \& Sertich (2010)- C77- 119; (mod) Pol \& Powell (2011)- C77- 119; (mod) Andrade et al. (2011)C342-343; Pol et al. (2012)- C77- 119: Participação do splenial na sínfise: ausente (0), presente (1).

330. Andrade et al. (2011)- C345: Participação do splenial na parede medial dos alvéolos posteriores: não participa (0), forma a parede medial dos alvéolos posteriores (1).

331. Pol \& Apesteguia (2005)- C184; Sereno \& Larsson (2009)- C180; Turner \& Sertich (2010)- C189; Pol \& Powell (2011)- C189; Pol et al. (2012)- C189: Superfície oclusal da sínfise mandibular: plana ou ligeiramente côncava (0), fortemente côncava (1).

332. Pol \& Apesteguia (2005)- C185; Turner \& Sertich (2010)- C190; Pol \& Powell (2011)C190; Andrade et al. (2011)- C334; Pol et al. (2012)- C190: Superfíce medial do 
esplenial posterior à sínfise: plana ou ligeiramente côncava (0), marcadamente côncava (1).

333. (mod) Wu \& Sues (1996)- C17; Larsson \& Sues (2007)- C111; Sereno \& Larsson (2009)- C179; Turner \& Sertich (2010)- C103; Pol \& Powell (2011)- 103; Pol et al. (2012)- C103: Sínfise mandibular em vista lateral: baixa e afilando anteriormente (0), alta e afilando anteriormente (1), alta e convexa anteriormente (2), baixa e convexa anteriormente (3).

334. Sereno \& Larsson (2009)- C178; Montefeltro et al. (2011)- C62; Andrade et al. (2011)C331: Orientação da região anterior da sínfise mandibular: horizontal, ou ligeiramente dorsalmente direcionado (0), formando um ângulo de aproximadamente 45 graus (1).

335. (mod) Pol (1999)- C212; Sereno \& Larsson (2009)- C186; Turner \& Sertich (2010)C154; Pol \& Powell (2011)- C154; (mod) Andrade et al. (2011)- C319- 320; Pol et al. (2012)- C154: Formato da participação do dentário na sínfise, em vista ventral: afilando anteriormente marcando um ângulo agudo (0), formando uma convexidade de curvatura suave anteriormente (1), margem anterior extensa e orientada perpendicularmente ao eixo sagittal da mandíbula (2).

336. Pol and Apesteguia (2005)- C180; Turner \& Sertich (2010)- C185; Pol \& Powell (2011)- 185; Andrade et al. (2011)- C344; Pol et al. (2012)- C185: Sutura entre o splenial e o dentário, em vista ventral: marcando um ângulo agudo (0), ou transversalmente orientada (1).

337. Ortega et al. (1996)- C7; Buckley \& Brochu (1999)- C110; Sereno \& Larsson (2009)C193; Turner \& Sertich (2010)- C161; Pol \& Powell (2011)- C161; Andrade et al. (2011)- C341; Pol et al. (2012)- C161: Esplenial posterior à sínfise: comprimido lateromedialmente $(0)$, robusto dorsalmente (1). 
338. Gasparini et al. (2006)- C245; Turner \& Sertich (2010)- C245; Pol \& Powell (2011)C245; Pol et al. (2012)- C245: Sulco do supra-angular: ausente (0), presente (1).

339. Ortega et al. (1996)- C5; Sereno \& Larsson (2009)- C187; Turner \& Sertich (2010)C118; Pol \& Powell (2011)- C118; Pol et al. (2012)- C118; Pol et al. (2012)- C118: Sulco na região posterior do dentário e anterior do supra-angular: ausente (0), presente (1).

340. (mod) Wilkinson et al. (2008)- C47; (mod) Young \& Andrade (2009)- C49; (mod) Young et al. (2011)- C2011; Andrade et al. (2011)- C346: Superfície ventral do supraangular em vista lateral: angular não se estende anterior ao nível da margem anterior das órbitas (0), supra-angular se estende anterior ao nível da margem anterior das órbitas (1).

341. (mod) Clark (1994)- C74; Turner \& Sertich (2010)- C74; Pol \& Powell (2011)- C74; (mod) Andrade et al. (2011)- C324; Pol et al. (2012)- C74: Margem dorsal do supraangular: retilínea (0), arqueada dorsalmente (1).

342. Pol \& Norell (2004b)- C187; Sereno \& Larsson (2009)- C202; Turner \& Sertich (2010)C220; Pol \& Powell (2011)- C220; Pol et al. (2012)- C220: Crista longitudinal na superfície dorsolateral do supra-angular: ausente (0), presente (1).

343. Turner \& Buckley (2008)- C287; Turner \& Sertich (2010)- C287; Andrade et al. (2011)- C330: Expansão lateral da margem posterodorsal do supra-angular na região anterior à fossa glenóide: ausente (0), presente (1).

344. Buckley \& Brochu (1999)- C102; Sereno \& Larsson (2009)- C198; Turner \& Sertich (2010)- C156; Pol \& Powell (2011)- C156; Andrade et al. (2011)- C357; Pol et al. (2012)- C156: Contribuição do supra-angular na fossa glenóide: forma somente a parede lateral da fossa glenóide (0), forma aproximadamente o terço lateral da fossa glenóide (1). 
345. Clark (1994)- C76; Sereno \& Larsson (2009)- C201; Turner \& Sertich (2010)- C76; Montefeltro et al. (2011)- C65; Pol \& Powell (2011)- C76; Andrade et al. (2011)- C353; Pol et al. (2012)- C76: Inserção do músculo pterygoideous posterior: não se estende a superfície lateral do angular (0), se estende a superfície lateral do angular (1).

346. (mod) Norell (1988)- C42; (mod) Brochu (1999)- C51; Larsson \& Sues (2007)- C118; Sereno \& Larsson (2009)- C199; Turner \& Sertich (2010)- C301; Andrade et al. (2011)C350: Extensão posterior do supra-angular: presente em toda a extensão do processo retroarticular (0), excluído da porção distal do processo retroarticular (1).

347. Pol et al. (2009)- C280; Turner \& Sertich (2010)- C280; Pol \& Powell (2011)- C280; Pol et al. (2012)- C280: Formato da margem posteroventral do angular: retilínea ou suavemente curvada (0), conspicuamente recurvada dorsalmente (1).

348. Wu et al. (1997)- C110; Turner \& Sertich (2010)- C201; Pol \& Powell (2011)- C201; Pol et al. (2012)- C201: Angular posterior à fenestra mandibular: exposto na superfície lateral da mandibular (0), deslocado para a superfície ventral da mandibular (1).

349. (mod) Pol \& Norell (2004b)- C186; (mod) Pol et al. (2009)- C219; Sereno \& Larsson (2009)- C203; (mod) Turner \& Sertich (2010)- C219; (mod) Pol \& Powell (2011)(mod) C219; Pol et al. (2012)- C219: Crista proeminente na superfície ventrolateral do angular: ausente (0), presente (1).

350. (mod) Pol \& Norell (2004b)- C186; (mod) Pol et al. (2009)- C219; (mod) Sereno \& Larsson (2009)- C203; (mod) Turner \& Sertich (2010)- C219; (mod) Pol \& Powell (2011)- C219; (mod) Pol et al. (2012)- C219: Crista proeminente na margem ventral do angular: ventralmente direcionada (0), lateralmente direcionada (1).

351. Clark (1994)- Sereno \& Larsson (2009)- C204; Turner \& Sertich (2010)- C72; Pol \& Powell (2011)- C72; Andrade et al. (2011)- C354; Pol et al. (2012)- C72: Pré-articular: presente (0), ausente (1). 
352. (mod) Wu \& Sues (1996)- C23; (mod) Turner \& Sertich (2010)- C104; (mod) Pol \& Powell (2011)- C104; Andrade et al. (2011)- C355; Pol et al. (2012)- C104: Faceta para a articulação do quadrado: mesmo comprimento que côndilos do quadrado (0), faceta moderadamente mais longa (1), faceta evidentemente mais longa (1).

353. (mod) Pol \& Apesteguia (2005)- C182; Turner \& Sertich (2010)- C187; Pol \& Powell (2011)-C187; (mod) Andrade et al. (2011)- C356; Pol et al. (2012)- C187: Margem posterior da fossa glenóide: bem delimitada por uma crista (0), margem posterior pouco delimitada, crista ausente (1).

354. (mod) Clark (1994)- C73; (mod) Turner \& Sertich (2010)- C73; (mod) Pol \& Powell (2011)- C73; Pol et al. (2012)- C73: Processo do articular contatando o otoccipital e basesfenóide: ausente (0), presente (1).

355. (mod) Clark (1994)- C71; (mod) Jouve et al. (2005)- C5; (mod) Larsson \& Sues (2007)C122; (mod) Sereno \& Larsson (2009)- C206; Turner \& Sertich (2010)- C71; (mod) Young et al. (2011)- C50; (mod) Andrade et al. (2011)- C358- 359- 360- 362- 363; Pol et al. (2012)- C71: Processo retroarticuar: ausente ou extremamente reduzido (0), com uma superfície extensa projetando posteroventralmente e voltada dorsomedialmente (1), alongada posteriormente, triangular e voltada dorsalmente (2), projetando posteroventralmente e paddle-shaped (3).

356. Andrade et al. (2011)- C361: Região distal do processo retroarticular: posicionado ventral à fossa glenóide (0), posicionado dorsal à fossa glenóide (1).

357. (mod) Ortega et al. (1996)- C11; (mod) Ortega et al. (2000)- C100; (mod) Sereno et al. (2003)- C53; (mod) Larsson \& Sues (2007)- C68; (mod) Sereno \& Larsson (2009)C114; (mod) Andrade \& Bertini (2008a)- C120; Turner \& Sertich (2010)- C120; (mod) Montefeltro et al. (2011)- C55; (mod) Pol \& Powell (2011)- C120; (mod) Young et al. (2011)- C171- 172; (mod) Andrade et al. (2011)- C378- 379; Pol et al. (2012)- C120: 
Carena dentária: lisa (0) com dentículos homogêneos (1) com dentículos tuberculares heterogêneos (2).

358. (mod) Pol (1999)- C154; (mod) Ortega et al. (2000)- C104; (mod) Andrade \& Bertini (2008a)- C135; (mod) Sereno \& Larsson (2009)- C116; (mod) Turner \& Sertich (2010)C140; (mod) Pol \& Powell (2011)- C140; (mod) Young et al. (2011)- C57; (mod) Andrade et al. (2011)- C368-369-393; Pol et al. (2012)- C140: Coroas dentárias na região mediana e posterior da série dentária da maxila e dentário: sessão transversal subcircular (0), moderadamente comprimidas lateralmente (1), fortemente comprimidas lateralmente (2).

359. Pol (1999)- C151; Turner \& Sertich (2010)- C137; (mod) Pol \& Powell (2011)- C137; (mod) Andrade et al. (2011)- C414; Pol et al. (2012)- C137: Implantação dentária na maxila e dentário: orientadas paralelas ao eixo sagittal do crânio (0), dentes maxilares implantados obliquamente (1), ambos dentes maxilares e dentários implantados obliquamente (2).

360. (mod) Andrade \& Bertini (2008a)- C135; (mod) Andrade et al. (2011)- C368-369-393: Compressão das coroas dentárias: compressão simétrica ou ausente (0), assimétrica, conferindo formato de gota à sessão transversal dos dentes (1).

361. (mod) Gomani (1997)- C46; (mod) Buckley et al. (2000)- C113; (mod) Andrade \& Bertini (2008a)- C149; (mod) Pol et al. (2009)- C188; Turner \& Sertich (2010)- C188; Pol \& Powell (2011)- C188; (mod) Andrade et al. (2011)- C377- 417; (mod) Pol et al. (2012)- C188: Cúspides dentárias acessórias: ausente (0), presente (1).

362. (mod) Gomani (1997)- C46; (mod) Buckley et al. (2000)- C113; (mod) Andrade \& Bertini (2008a)- C149; (mod) Pol et al. (2009)- C188; (mod) Turner \& Sertich (2010)C188; (mod) Pol \& Powell (2011)- C188; (mod) Andrade et al. (2011)- C377-417; 
(mod) Pol et al. (2012)- C188: Cúspides dentárias acessórias: formando uma única linha (0), arranjadas em mais de uma linha (1).

363. Gasparini et al. (2006)- C242; Turner \& Sertich (2010)- C242; Pol \& Powell (2011)C242; Andrade et al. (2011)- C419; Pol et al. (2012)- C242: Dentes posteriores com anéis de esmalte bem marcados: ausente (0), presente (1).

364. (mod) Andrade et al. (2011)- C375; Presença de cristas longitudinais de esmalte nos dentes posteriores: ausente (0), presente (1).

365. Turner \& Sertich (2010)- C294; Andrade et al. (2011)- C374: Presença de ornamentação granulada (pebbled) no esmalte dentário dos elementos posteriores da série: ausente (0), presente (1).

366. Andrade et al. (2011)- C376- 380- 381: Cristas acessórias nas superfícies labial e lingual dos dentes posteriores: ausente (0), presente (1).

367. (mod) Wu \& Sues (1996)- C27; (mod) Ortega et al. (2000)- C133; Turner \& Sertich (2010)- C106; Pol \& Powell (2011)- C106; (mod) Montefeltro et al. (2011)- C56; Young et al. (2011)- C52; Pol et al. (2012)- C106: Número de dentes pré-maxilares: seis (0), cinco (1), quarto (2), três (3), dois (4).

368. (mod) Wu \& Sues (1996)- C30; (mod) Sereno et al. (2003)- C51; (mod) Sereno \& Larsson (2009)- C112; Turner \& Sertich (2010)- C108; Pol \& Powell (2011)- C108; (mod) Montefeltro et al. (2011)- C59; Pol et al. (2012)- C108: Número de dentes maxilares: oito ou mais (0), sete (1), seis (2), cinco (3), quarto (4).

369. (mod) Sereno et al. (2001)- C69; (mod) Sereno \& Larsson (2009)- C97; (mod) Turner \& Sertich (2010)- C240; (mod) Pol \& Powell (2011)- C240; (mod) Andrade et al. (2011)C390; (mod) Pol et al. (2012)- C240:- Orientação das fileiras dentárias pré-maxilares: divergindo da linha média em uma curva suave (0), orientada transversalmente em 
relação à linha média (1), divergindo da linha média em um ângulo aproximado de 120 graus (2), divergindo da linha média em um ângulo aproximado de 60 graus (3).

370. Zaher et al. (2006)- C195; Sereno \& Larsson (2009)- C95; Turner \& Sertich (2010)C231; Pol \& Powell (2011)- C231; Pol et al. (2012)- C231: Dentes procumbentes prémaxilares: ausente (0), presente (1).

371. Larsson \& Gado (2000)- C162; Pol \& Powell (2011)- C283; Pol et al. (2012)- C283: Primeiro e segundo alvéolos pré-maxilares: separados (0), confluentes (1).

372. (mod) Clark (1994)- C78; (mod) Turner \& Sertich (2010)- C78; (mod) Montefeltro et al. (2011)- C57; Pol \& Powell (2011)- C78; Pol et al. (2012)- C78: Dentes prémaxilares posteriores: tamanho similar aos dentes anteriores (0), muito mais longos (1).

373. Sereno et al. (2001)- C70; Sereno \& Larsson (2009)- C98; Turner \& Sertich (2010)C241; Pol \& Powell (2011)- C141; (mod) Andrade et al. (2011)- C391; Pol et al. (2012)- C141: Posição do ultimo dente pré-maxilar e a fileira dentária da maxila: disposto anteriormente ou anteromedialmente (0), disposto anterolateralmente (1).

374. (mod) Clark (1994)- C79; Turner \& Sertich (2010)- C79; Pol \& Powell (2011)- C79; Young et al. (2011)- C115; (mod)- Andrade et al. (2011)- C80- 82; (mod) Andrade et al. (2011)- C397; Pol et al. (2012)- C79: Tamanho dos dentes maxilares: sem variação conspícua no tamanho dos dentes (0), dentes engrandecidos formando uma onda (1), dentes formando duas ondas (2).

375. (mod) Ortega et al. (2000)- C18; (mod) Andrade et al. (2011)- C394- 395: Fileiras dentárias maxilares: não ultrapassam o nível da margem anterior da fenestra suborbital (0), ultrapassam o nível da margem anterior da fenestra suborbital (1).

376. Andrade \& Bertini (2008a)- C131; Turner \& Sertich (2010)- C299; Andrade et al. (2011)- C412: Tamanho relativo dos dentes maxilares e a superfície palatal maxilar: 
dentes proporcionalmente pequenos, ocupando uma área marginal do crânio (0), relativamente grande, ocupando grande parte da superfície palatal maxilar (1).

377. (mod) Andrade et al. (2011)- C413: Tamanho relativo do sétimo e oitavo dente mandibular: mesmo tamanho (0), sétimo dente muito menor que o oitavo (1).

378. (mod) Ortega et al. (2000)- C19; Sereno \& Larsson (2009)- C113; Turner \& Sertich (2010)- C164; Pol \& Powell (2011)- C164; Andrade et al. (2011)- C396; Pol et al. (2012)- C164: Implantação dentária maxilar: dentes implantados em alvéolos isolados (0), dentes implantados em um sulco dental comum (1).

379. Turner \& Sertich (2010)- C296: Dente com morfologia transicional na sutura prémaxila/maxila: ausente (0), presente (1).

380. Ortega et al. (1996)- C13; Buckley et al. (2000)- C117; Sereno \& Larsson (2009)C119; Turner \& Sertich (2010)- C162; Pol \& Powell (2011)- C162; Young et al. (2011)- C59; Pol et al. (2012)- C162: Base dos dentes posteriores da maxila: sem constrição (0), com uma constrição (1).

381. Turner \& Sertich (2010)- C295: Faceta de desgaste nos dentes posteriores: ausente (0), presente (1).

382. Ortega et al. (2000)- C101; Turner \& Sertich (2010)- C176; (mod) Pol \& Powell (2011)- C176; Pol et al. (2012)- C176: Largura da raiz dentária em relação à largura da coroa: mais restrita (0), mais larga (1).

383. (mod) Ortega et al. (2000)- C156; Sereno \& Larsson (2009)- C117; (mod) Turner \& Sertich (2010)- C184; (mod) Pol \& Powell (2011)- C184; (mod) Andrade et al. (2011)C84- 392; (mod) Pol et al. (2012)- C184: Posição do primeiro dente maxilar hipertrofiado: dentes relativamente homodonte (0), Segundo ou terceiro alvéolo (1), quarto ou quinto alvéolo (2). 
384. Clark (1994)- C80; (mod) Sereno \& Larsson (2009)- C184; Turner \& Sertich (2010)C80; Pol \& Powell (2011)- C80; (mod) Andrade et al. (2011)- C408- 409- 411- 317 404; Pol et al. (2012)- C80: Comprimento do dente dentário oposto à sutura pré-maxilamaxila: menos que duas vezes maior que outros dentes do dentário (0) duas vezes maior que outros dentes do dentário (1).

385. Buscallioni \& Sanz (1988)- C35; Sereno \& Larsson (2009)- C209; Turner \& Sertich (2010)- C113; Pol \& Powell (2011)- C103; Pol et al. (2012)- C103: Centro vertebral: cilíndrico (0), em formato de carretel (spool-shaped) (1).

386. Clark (1994)- C89; Turner \& Sertich (2010)- C89; Pol \& Powell (2011)- C89; Pol et al. (2012)- C89: Tamanho do intercentro do atlas: mais largo que longo (0), tão longo quanto largo (1).

387. Larsson \& Sues (2007)- C130; Sereno \& Larsson (2009)- C211: Altura do espinho neural do axis: subigual à altura do centro axial (0), metade da altura do centro axial (1).

388. Pol (1999)- C168; Sereno \& Larsson (2009)- C214; Turner \& Sertich (2010)- C151; Pol \& Powell (2011)- C151; (mod) Andrade et al. (2011)- C423; Pol et al. (2012)- C151: Desenvolvimento anteroposterior do espinho neural do axis: bem desenvolvido, cobrindo todo o comprimento do arco neural axial (0), reduzido, localizado na metade posterior do comprimento do arco neural (1).

389. Brochu (1999)- C3; Turner \& Sertich (2010)- C258; Pol \& powell (2011)- C258; Andrade et al. (2011)- C425; Pol et al. (2012)- C258: Largura da metade posterior do espinho neural do axis: largo (0), comprimido lateralmente (1).

390. Pol (1999)- C169; Turner \& Sertich (2010)- C152; Pol \& Powell (2011)- C152; Pol et al. (2012)- C152: Desenvolvimento relativo das pré-zigapófises do axis e o arco neural axial: pré-zigapófises não excedendo a margem anterior do arco neural (0), prézigapófises excedendo a margem anterior do arco neural (1). 
391. Pol (1999)- C170; Sereno \& Larsson (2009)- C213; Turner \& Sertich (2010)- C153;Pol \& Powell (2011)- C153; Pol et al. (2012)- C153: Pós-zigapófises do axis: bem desenvolvida e curvando lateralmente (0), pouco desenvolvida (1).

392. Brochu (1999)- C19; Turner \& Sertich (2010)- C259; Pol \& Powell (2011)- C259; Andrade et al. (2011)- C426; Pol et al. (2012)- C259: Bifurcação da hipapófise axial: presente (0), ausente (1).

393. (mod) Clark (1994)- C90; (mod) Sereno \& Larsson (2009)- C210; (mod) Turner \& Sertich (2010)- C90; (mod) Pol \& Powell (2011)- C90; (mod) Andrade et al. (2011)C428- 429; (mod) Pol et al. (2012)- C90: Espinhos neurais cervicais de sessão transversal arredondada: ausente (0), presente (1).

394. Clark (1994)- C92; Sereno \& Larsson (2009)- C215; Turner \& Sertich (2010)- C92; Pol \& Powell (2011)- C92; Pol et al. (2012)- C92: Centros vertebrais cervicais: anficélicos (0), procélicos (1).

395. Andrade \& Bertini (2008a)- C154; Andrade et al. (2011)- C430: Base dos espinhos neurais das vértebras cervicais anteriores: espinho neural claramente distinto do arco neural (0), base robusta com a formação das cristas espinozigapofiseais (1).

396. Pol et al. (2012)- C296: Processo pré-zigapofiseal das vértebras cervicais anteriores: projetando anterodorsalmente em linha reta (0), projetando dorsalmente e fortemente recurvado (1).

397. Pol et al. (2012)- C297: Processo pré-zigapofiseal das vértebras cervicais anteriores e medianas em vista lateral: margem anterior retilínea ou convexa (0), margem anterior possuindo uma convexidade distinta no ponto médio do processo pré-zigapofiseal (1).

398. Pol et al. (2012)- C298: Forma da faceta articular da parapófise nas vértebras cervicais posteriores e dorsais anteriores: subcircular/ovoide com maior eixo 
anteroposteriormente direcionado (0), subtriangular/ovoide com maior eixo dorsoventralmente direcionado (1).

399. Andrade \& Bertini (2008a)- C157; Andrade et al. (2011)- C431: Base dos espinhos neurais das vértebras cervicais posteriores: espinho neural claramente distinto do arco neural (0), base robusta com a formação das cristas espinozigapofiseais (1).

400. Andrade et al. (2011)- C427: Pré-zigapófises da terceira vértebra cervical: pouco desenvolvidas, se projetando pouco anterior ao centro vertebral (0), bem desenvolvidas, se projetando grandemente anterior ao centro vertebral (1).

401. (mod) Buscallioni \& Sanz (1988)- C37; (mod) Sereno \& Larsson (2009)- C216; (mod) Turner \& Sertich (2010)- C91; (mod) Pol \& Powell (2011)- C91; (mod) Andrade et al. (2011)- C421; Pol et al. (2012)- C91: Hipapófises nas vértebras cérvico-dorsais: ausente (0), presente (1).

402. (mod) Buscallioni \& Sanz (1988)- C37; (mod) Sereno \& Larsson (2009)- C216; (mod) Turner \& Sertich (2010)- C91; (mod) Pol \& Powell (2011)- C91; (mod) Andrade et al. (2011)- C421; Pol et al. (2012)- C91: Hipapófises nas vértebras cérvico-dorsais: restritas à vértebras cervicais (0), presente nas vértebras cervicais e dorsais (1).

403. Clark (1994)- C93; Sereno \& Larsson (2009)- C218; Turner \& Sertich (2010)- C93; Pol \& Powell (2011)- C93; Andrade et al. (2011)- 419-420; Pol et al. (2012)- C93: Vértebras dorsais anficélicas (0), procélicas (1).

404. (mod) Buscalioni \& Sanz (1988)- C39; Turner \& Sertich (2010)- C114; Pol \& Powell (2011)- C114; Pol et al. (2012)- C114: Processo transverso das vértebras dorsais: baixo e laminar (0), alto dorsoventralmente (1).

405. Pol et al. (2012)- C299: Migração dorsal da parapófise nos arcos neurais nas vértebras dorsais medianas: vértebras dorsais 4-9 apresentando a migração gradual das parapófises, com pelo menos duas vértebras com a parapófise localizada na base do 
pedicelo do arco vertebral, ventral à diapófise (0), migração abrupta, com vértebra dorsal 4 com a parapófise na sutura neurocentral e vértebra 5 com a parapófise na mesma altura que a diapófise, formando o processo transversal (1).

406. Pol et al. (2012)- C300: Superfície medial do processo pré-zigapofiseal das vértebras cervicais anteriores e medianas: plana ou levemente convexa (0), com uma depressão ovoide ou triangular próximo ao arco neural (1).

407. Pol et al. (2012)- C301: Lâmina spinopós-zigapofiseal nas vértebras dorsais: ausente (0), presente como uma lâmina bem desenvolvida (1).

408. Pol et al. (2012)- C302: Depressão na superfície dorsal dos arcos neurais das vértebras dorsais anteriores e medianas entre os processos pós-zigapofiseais: ausente (0), presente (1).

409. Pol et al. (2012)- C303: Posição relativa entre processo transverso e pós-zigapófises nas vértebras dorsais medianas: pós-zigapofíses dorsais ao processo tranverso (0), pószigapófises no mesmo nível que o processo transverso (1).

410. Buscalioni \& Sanz (1988)- C44; Sereno \& Larsson (2009)- C219; Turner \& Sertich (2010)- C115; Pol \& Powell (2011)- C115; Andrade et al. (2011)- C432; Pol et al. (2012)- C115: Número de vértebras sacrais: duas (0), mais que duas (1).

411. Gasparini et al. (2006)- C255; Sereno \& Larsson (2009)- C221; Turner \& Sertich (2010)- C255; Pol \& Powell (2011)- C255; Andrade et al. (2011)- C433- 434; Pol et al. (2012)- C255: Direção do processo transverso das vértebras sacrais: lateral (0), ventrolateralmente direcionado (1).

412. Pol et al. (2012)- C304: Região dorsalateral da primeira costela sacral: no mesmo nível que o canal neural (0), expandida dorsolateral, projetando dorsalmente ao nível do canal neural (1). 
413. (mod) Clark (1994)- C94; Larsson \& Sues (2007)- C134; Sereno \& Larsson (2009)C220; (mod) Turner \& Sertich (2010)- C94; (mod) Pol \& Powell (2011)- C94; (mod) Andrade et al. (2011)- C422; (mod) Pol et al. (2012)- C94: Primeira vértebra caudal: anficélica (0), biconvexa (1).

414. Young \& Andrade (2009)- C61; Andrade et al. (2011)- C436: Última vértebras caudais: uma série contínua com as vértebras mais proximais (0), ventralmente direcionadas (1).

415. (mod) Turner (2006)- C129; Sereno \& Larsson (2009)- C217; Turner \& Sertich (2010)C273; Pol \& Powell (2011)- C273; Pol et al. (2012)- C273: Espinho se projetando posterodorsalmente a partir do processo posterior das costelas cervicais no contato com o processo tubercular: ausente (0), presente (1).

416. (mod) Clark (1994)- C82; (mod) Ortega et al. (2000)- C120; (mod) Sereno \& Larsson (2009)- C223; (mod) Turner \& Sertich (2010)- C82; (mod) Pol \& Powell (2011)- C82; Andrade et al. (2011)- C439; (mod) Pol et al. (2012)- C82: Margem anterior da escápula: margem fortemente côncava (0), margem relativamente retilínea (1).

417. Buckley \& Brochu (1999)- C106; Sereno \& Larsson (2009)- C222; Turner \& Sertich (2010)- C283; Pol et al. (2012)- C305: Largura da lâmina escapular: menor que duas vezes a largura da articulação da escápula com o coracóide (0), maior que duas vezes a largura da articulação da escápula com o coracóide (1).

418. Brochu (1999)- C29; Sereno \& Larsson (2009)- C228; Turner \& Sertich (2010)- C261; Pol \& Powell (2011)- C261; Andrade et al. (2011)- C456; Pol et al. (2012)- C261: Inserção do músculo teres major e músculo dorsalis scapulae separadas no úmero: sim (0), não (1).

419. Pol et al. (2012)- C306: Cicatriz do músculo tríceps dorsal à glenoide escapular: presente como uma crista bem desenvolvida (0), ausente (1). 
420. Wu \& Sues (1996)- C33; (mod) Turner \& Sertich (2010)- C109; (mod) Pol \& Powell (2011)- C109; (mod) Pol et al. (2012)- C109: Processo medial do coracóide: processo alongado direcionado posteromedialmente (0), proceesso expandido distalmente e direcionado ventromedialmente (1).

421. (mod) Clark (1994)- C83; Sereno \& Larsson (2009)- C225; Turner \& Sertich (2010)C83; Pol \& Powell (2011)- C83; Andrade et al. (2011)- C440; Pol et al. (2012)- C83: Comprimento do coracóide: até dois terços do comprimento da escápula (0), comprimento subigual ao comprimento da escápula (1).

422. Pol et al. (2012)- C308: Expansão distal do coracoide: maior ou igual à expansão proximal (0), menos desenvolvido que a região proximal (1).

423. Pol et al. (2012)- C307: Recesso ventral à glenoide do coracoide: rasa, apresentando uma leve concavidade (0), recesso bem marcado, côncavo em vista lateral, encoberto por uma projeção ventral da glenóide (1).

424. Pol et al. (2012)- C309: Orientação da área de inserção do músculo subscapularis sobre a tuberosidade interna do úmero: orientada obliquamente em vista anterior, com a área de inserção orientada proximomedialmente (0), orientada verticalmente em vista anterior, com a área de inserção orientada medialmente (1).

425. Pol et al. (2012)- C310: Formato da crista deltapeitoral do úmero e sua projeção: crista bem desenvolvida com um tubérculo bem desenvolvido para a inserção do complexo supracoracoideus, Meers (2003) (0), crista baixa convexa em vista lateral sem um tubérculo bem desenvolvido (1).

426. Pol et al. (2012)- C311: Terço proximal da crista deltapeitoral: originando no ponto mais proximolateral do úmero e se estendendo distalmente pela margem lateral do úmero (0), origem proximal deslocada medialmente do ponto mais proximolateral do 
úmero e se estendendo distalmente marcando uma superfície côncava entre a crista e margem lateral do úmero (1).

427. Pol et al. (2012)- C312: Orientação da metade distal da crista deltapetoral: crista posicionada na margem lateral do úmero atingindo no máximo o ponto médio do comprimento lateromedial do úmero (0), medialmente direcionada ultrapassando o ponto médio do comprimento lateromedial do úmero (1).

428. Pol et al. (2012)- C313: Superfície anterior da metade distal da crista deltapeitoral: formando uma crista lateromedilamente restrita (0), com uma superfície lateromedial expandida (1).

429. Pol et al. (2012)- C314: Depressão circular na superfície posteroproximal do úmero relacionada à inserção do músculo scapulohumeralis caudalis: ausente (0), presente (1).

430. Pol et al. (2012)- C317: Superfícies medial e lateral da porção distal do úmero: plana e anteroposteriormente larga, similar ao comprimento lateromedial da porção distal do úmero (0), convexa e reduzida em comparação ao comprimento lateromedial da porção distal do úmero (1).

431. Brochu (1999)- C27; Sereno \& Larsson (2009)- C229; Turner \& Sertich (2010)- C260; Pol \& Powell (2011)- C260; Andrade et al. (2011)- C457; Pol et al. (2012)- C260: Largura do processo olecrano da ulna: estreito e com margens angulosas (0), largo e arredondado (1).

432. Pol et al. (2012)- C318: Superfície articular da ulna com o radiale: voltada posterolateralmente (0), voltada posteriormente, não visível em vista lateral (1).

433. Pol et al. (2012)- C319: Desenvolvimento proximodistal da superfície articular da ulna com o radial: curta e larga, até $30 \%$ do comprimento total do radial (0), alongada proximodistalmente, com comprimento total maior que $40 \%$ do comprimento do radial (1). 
434. Buscallioni \& Sanz (1988)- C54; Turner \& Sertich (2010)- C117; Pol \& Powell (2011)C117; Andrade et al. (2011)- C462; Pol et al. (2012)- C117: Formato da região proximal do radial: expandida simetricamente como a região distal (0), mais expandida lateralmente que medialmente (1).

435. Ortega et al. (2000)- C127; Andrade et al. (2011)- C459: Proporções do radial: muito mais longo que largo (0), largura proximal subigual ao comprimento total (1).

436. Pol et al. (2012)- C320: Região distal da superfície articular do radial com o ulnar: superfície articular emergindo gradualmente do eixo do radial (0), separada do eixo do radial por um desnível (1)

437. Pol et al. (2012)- C321: Região proximal da superfície articular do radial com o ulnar: separada da superfície articular para a ulna por uma crista (0), contínua com a superfície articular com a ulna (1).

438. Pol et al. (2012)- C322: Superfície anterior do radial: convexa (0), com uma crista proximodistal que divide a superfície anterior do radial (1).

439. Pol et al. (2012)- C323: Expansão distolateral do ulnar: menos expandida que a região distomedial do ulnar (0), projetando mais distalmente que a região distomedial formando a projeção ulnar anterior, Nascimento \& Zaher (2010) (1).

440. Pol et al. (2012)- C324: Largura lateromedial do eixo do metacarpal I: tão largo quanto o eixo dos demais metacarpais (0), mais largo que os demais metacarpais, com o dígito I sendo o mais robusto (1).

441. Clark (1994)- C84; Sereno \& Larsson (2009)- C231; Turner \& Sertich (2010)- C84; Pol \& Powell (2011)- C84; Andrade et al. (2011)- C441; Pol et al. (2012)- C84: Processo anterior do ílio: comprimento similar ao comprimento do processo posterior do ílio (0), comprimento do processo anterior um quarto ou menor que o comprimento do processo posterior (1). 
442. (mod) Buscallioni \& Sanz (1988)- C49; (mod) Sereno \& Larsson (2009)- C234; (mod) Turner \& Sertich (2010)- C116; (mod) Pol \& Powell (2011)- C116; (mod) Pol et al. (2012)- C116: Superfície rugosa resultante da inserção do músculo iliotibialis formando a crista supra-acetabular: restrita lateromedialmente (0), lateromedialmente expandida (1).

443. Pol et al. (2012)- C325: Processo pós-acetabular do ílio: bem desenvolvido como um processo distinto com pelo menos $60 \%$ da comprimento acetabular (0), reduzido, não possuindo mais que $50 \%$ do comprimento acetabular (1).

444. Pol et al. (2012)- C326: Região posterior do processo pós-acetabular: afilando (0), subretangular e orientado verticalmente com pelo menos $60 \%$ da altura da origem do processo pós-acetabular (1).

445. Pol et al. (2012)- C327: Orientação da margem ventral do processo pós-acetabular: posterodorsalmente direcionado (0), horizontal ou ligeiramente posteroventralmente direcionado (1).

446. Pol et al. (2012)- C328: Posição da margem ventral do processo pós-acetabular em seu terço posterior: dorsal à margem acetabular dorsal (0), no mesmo nível ou ventral ao ponto médio da altura acetabular (1).

447. (mod) Buscallioni \& Sanz (1988)- C49; (mod) Sereno \& Larsson (2009)- C234; (mod) Turner \& Sertich (2010)- C116; (mod) Pol \& Powell (2011)- C116; (mod) Pol et al. (2012)- C116: Orientação da superfície rugosa resultante da inserção do músculo iliotibialis formando a crista supra-acetabular: dorsal ou dorsolateralmente (0), lateralmente (1).

448. Clark (1994)- C85; Turner \& Sertich (2010)- C85; Pol \& Powell (2011)- C85; Andrade et al. (2011)- C447; Pol et al. (2012)- C84: Formato do púbis: sessão transversal arredondada ao longo de toda a extensão (0), expandido distalmente (1). 
449. (mod) Clark (1994)- C86; (mod) Sereno \& Larsson (2009)- C235; (mod) Turner \& Sertich (2010)- C86; (mod) Pol \& Powell (2011)- C86; Andrade et al. (2011)- C444; Pol et al. (2012)- C86: Processo anterior do ísquio: ausente (0), presente (1).

450. (mod) Clark (1994)- C86; (mod) Sereno \& Larsson (2009)- C235; (mod) Turner \& Sertich (2010)- C86; (mod) Pol \& Powell (2011)- C86; (mod) Andrade et al. (2011)C445; Pol et al. (2012)- C86: Processo anterior do ísquio: não exclui o pubis da margem do acetábulo (0), exclui o pubis da margem do acetábulo (1).

451. (mod) Buckley \& Brochu (1999)- C102; (mod) Sereno \& Larsson (2009)- C236; (mod) Turner \& Sertich (2010)- C157; (mod) Pol \& Powell (2011)- C157; Pol et al. (2012)C157: Margem anterior do fêmur na area para a inserção do músculo puboischiofemoralis internus 1 e músculo caudofemoralis longus: margem anterior linear (0), possuindo uma projeção distinta e côncavo dorsal à essa projeção (1).

452. Pol et al. (2012)- C331: Desenvolvimento do trocanter maior do fêmur: proeminente, alcançando o nível do quarto trocanter e com uma borda lateral em crista que separa a superfície lateral do fêmur da superfície plana posterior do fêmur (0), superfície reduzida proximodistalmente, não alcançando o nível do quarto trocanter e sem uma crista separando as superfícies proximal e posterior (1).

453. Pol et al. (2012)- C334: Crista supracondilar lateral na superfície anterior da região distal do fêmur: bem desenvolvida e separando a superfície lateral da superfície côncava anterior do fêmur (0), crista ausente, com superfície anterior do fêmur plana (1).

454. (mod) Turner (2006)- C128; Pol et al. (2009)- C272; Sereno \& Larsson (2009)- C237; Turner \& Sertich (2010)- C272; Pol \& Powell (2011)- C272: Projeção posterior da região proximal da cabeça fibular: ausente (0), presente (1).

455. Pol et al. (2012)-C336: Eixo tibial em vistas anterior e posterior: retilínea ou ligeiramente arqueado (0), fortemente arqueado lateralmente (1). 
456. Pol et al. (2012)- C337: Projeção distal das facetas articulares da tíbia: região medial da faceta articular distal da tíbia se estende distalmente à região lateral, marcando uma margem distal da tíbia oblíqua (0), regiões medial e distal subigualmente expandidas, formando a margem distal da tíbia retilínea (1).

457. Pol et al. (2012)- C338: Margem anterior da faceta tibial para o astrágalo: formando uma crista bem delimitada atingindo a região esférica para a articulação dos meta-tarsais I e II fechando a região anteromedial da concavidade anterior do astrágalo (0), formando uma crista baixa separada medialmente da região esférica do astrágalo para a articulação dos meta-tarsais I e II por um entalhe e não fechando a região anteromedial da concavidade anterior do astrágalo (1).

458. Pol et al. (2012)- C339: Superfícies plantar e calcânear do astrágalo: conectadas entre si e formando uma superfície articular contínua com o côndilo calcaneal, cuja margem distal forma uma crista na margem distolateral da concavidade do astrágalo (0), separadas formando superfícies articulares distintas (1).

459. Pol et al. (2012)- C340: Superfície articular para o tarsal distal III no astrágalo: em nível com a região distal da faceta plantar do calcâneo e com a superfície distal da articulação esférica para os meta-tarsais I e II, em vista anterior, estas estruturas formam um crista elevada que fecha a região anterodistal da concavidade do astrágalo (0), deslocada proximalmente formando uma separação clara entre a faceta plantar e a superfície distal da articulação esférica para os meta-tarsais I e II, marcando uma incisura distal ao longo da margem anterior da concavidade do astrágalo (1).

460. Pol et al. (2012)- C341: Fenda para o ligamento astragalar-tarsal (Sertich \& Groenke, 2010) na região distal da concavidade anterior: não diferenciada do restante da concavidade anterior (0), depressão distinta, separada da concavidade anterior por uma crista obliqua na margem proximolateral do ligamento astragalar-tarsal (1). 
461. Pol et al. (2012)- C342: Desenvolvimento da depressão astragalar proximal localizada posteriormente à faceta tibial do astrágalo: depressão rasa e pouco desenvolvida (0), depressão profunda com margens anterior e medial delimitadas, marcando uma fossa astragalar (1).

462. (mod) Pol et al. (2012)- C343: Formato da faceta fibular do astrágalo: subretangular com margens anterior e posterior subiguais (0), trapezoidal, com margem anterior mais baixa que a margem posterior (1).

463. Pol et al. (2012)- C347: Faceta astragalar posterior do calcâneo: subtriangular com margens proximal e lateral formando um ângulo reto e margem medioplantar obliqua (0), margens plantar e proximal subparalelas conectas por uma margem medial larga e arredondada (1).

464. (mod) Clark (1994)- C95; (mod) Sereno \& Larsson (2009)- C247; (mod) Turner \& Sertich (2010)- C95; Pol \& Powell (2011)- C95; (mod) Andrade et al. (2011)- C475; Pol et al. (2012)- C95: Formato dos osteodermos dorsais: arredondados (0), retangular, pelo menos três vezes mais largos que longos (1), retangular, menos que 2 três vezes mais largos que longo (2), quadrado (3).

465. (mod) Clark (1994)- C96; (mod) Brochu (1999)- C40; (mod) Turner \& Sertich (2010)C96; (mod) Pol \& Powell (2011)- C96; (mod) Andrade et al. (2011)- C477; Pol et al. (2012)- C96: Processo articular anterior dos osteodermos dorsais: ausente (0), presente (1).

466. (mod) Clark (1994)- C96; (mod) Brochu (1999)- C40; (mod) Turner \& Sertich (2010)C96; (mod) Pol \& Powell (2011)- C96; (mod) Andrade et al. (2011)- C477; Pol et al. (2012)- C96: Processo articular anterior dos osteodermos dorsais: margem convexa (0), processo anterolateral bem desenvolvido (1). 
467. Clark (1994)- C101; Sereno \& Larsson (2009)- C249; Pol et al. (2009)- C101; Turner \& Sertich (2010)- C101; Pol \& Powell (2011)- C101; Andrade et al. (2011)- C478; Pol et al. (2012)- C101: Quilha na superfície dorsal dos osteodermos dorsais: ausente (0), presente (1).

468. Pol et al. (2009)- C274; Turner \& Sertich (2010)- C274; Pol \& Powell (2011)- C274; (mod) Andrade et al. (2011)- C482; Pol et al. (2012)- C274: Quilha na superfície dorsal dos osteodermos dorsais: estendendo por toda a superfície dorsal do osteodermo (0), restrita a metade posterior (1).

469. (mod) Clark (1994)- C98; (mod) Turner \& Sertich (2010)- C98; Pol \& Powell (2011)C98; (mod) Andrade et al. (2011)- C474; Pol et al. (2012)- C98: Contato entre os osteodermos: imbricados (0), suturados um ao outro (1), não contatam (2).

470. Ortega et al. (2000)- C109; Sereno \& Larsson (2009)- C245; Turner \& Sertich (2010)C177; Pol \& Powell (2011)- C177; Pol et al. (2012)- C177: Armadura de osteodermos cervical e dorsal: contínuas (0), com uma interrupção no limite entre as duas séries (1).

471. Andrade et al. (2011)- C471: Armadura de osteodermos pré-sacral: mesma morfologia ao longo da série independente das descontinuidade da série (0), osteodermos cervicais com morfologia distinta (1).

472. (mod) Clark (1994)- C97; (mod) Sereno \& Larsson (2009)- C246; (mod) Turner \& Sertich (2010)- C97; Pol \& Powell (2011)- C97; Andrade et al. (2011)- C472; (mod) Pol et al. (2012)- C97: Fileiras de osteodermos dorsais primários (sensu Frey, 1988): presente (0), ausente (1).

473. (mod) Clark (1994)- C97; (mod) Sereno \& Larsson (2009)- C246; (mod) Turner \& Sertich (2010)- C97; Pol \& Powell (2011)- C97; Andrade et al. (2011)- C472; (mod) Pol et al. (2012)- C97: Fileiras de osteodermos dorsais primários (sensu Frey, 1988): duas fileiras paralelas (0), quatro fileiras (1), mais que quatro fileiras (2). 
474. Turner \& Sertich (2010)- C298: Fileiras acessórias de osteodermos dorsais (sensu, Frey 1988): ausente (0), presente (1).

475. Clark (1994)- C100; Sereno \& Larsson (2009)- C251; Turner \& Sertich (2010)- C100; Pol \& Powell (2011)- C100; Andrade et al. (2011)- C468; Pol et al. (2012)- C100: Osteodermos ventrais: ausente (0), presente (1).

476. (mod) Clark (1994)- C99; (mod) Sereno \& Larsson (2009)- C252; (mod) Turner \& Sertich (2010)- C99; (mod) Pol \& Powell (2011)- C99; (mod) Andrade et al. (2011)C481; Pol et al. (2012)- C99: Osteodermos caudais: somente na região dorsal (0), cauda completamente encoberta de osteodermos (1).

477. Pol \& Norell (2004b)- C190; Turner \& Sertich (2010)- C223; Pol \& Powell (2011)C223; Pol et al. (2012)- C223: Osteodermos apendiculares: ausente (0), presente (1).

478. (novo) Constrição do processo anterior do frontal: ausente (0), presente, processo anterior com uma constrição em sua porção mais proximal (1).

479. (novo) Margem dorsal sulco para a aba do ouvido externo: paralela à ventral (0), margem dorsal com uma curvatura medial (1).

480. (novo) Tamanho da abertura dorsal do canal orbito-temporal: pequeno, menos que $30 \%$ da área da fenestra temporal superior interna (0), grande, mais que 30\% da área da fenestra temporal superior interna (1).

481. (novo) Ornamentação da região posterolateral do squamosal próxima à margem da fenestra temporal superior externa: mesmo padrão de ornamentação do restante do crânio (0), com uma ornamentação granulada peculiar (1).

482. (novo) Participação do frontal na órbita primária, excluindo os palpebrais: restrita a região posterior (0), formando grande parte da margem mediana e anterior (1).

483. (novo) Forâmen sifonal na base da base da barra pós-orbital: ausente (0), presente (1). 
484. (novo) Forâmen sifonal na base da barra pós-orbital: não visível em vista lateral (0), visível em vista lateral (1).

485. (novo) Crista na região posterior do parietal: ausente (0), presente (1).

486. (novo) Superfície dorsal do parietal com uma saliência com ornamentação bem definida: ausente (0), presente (1).

487. (novo) Par de foramens localizados na região anterior da superfície ventral do palatino (não homólogos à fenestra maxilo-palatina e canais palatinos): ausente (0), presente (1).

488. (novo) Orientação principal do forâmen eustaquiano médio: ventral (0), lateral (1), posterior (2).

489. (novo) Forâmen esutaquiano medial: com parede posterior (0), sem parede posterior (1).

490. (novo) Altura dorsoventral da região proximal do corpo do processo articular do quadrado: menor que $50 \%$ da largura do teto craniano (0), mais que 50\% da largura do teto craniano (1).

491. (novo) Superfície proximal do côndilo occipital: superfície gradualmente se estende para a superfície occipital do crânio (0), constrita, marcando um pescoço na base do côndilo occipital (1).

492. (novo) Contato medial entre os processos paraoccipitais dorsal ao foramen magnum: plano (0), cristas parasagitais presentes formando um sulco bem desenvolvido dorsal ao foramen magnum (1).

493. (novo) Diástema entre o sétimo e oitavo alvéolo mandibular: ausente, alvéolos regularmente espaçados (0), presente, dentes sétimo e oitavo separados entre si e aproximados do sexto e nono alvéolos respectivamente (1).

494. (novo)-Número de linhas de foramens neurovasculares da região anterior do dentário: uma linha principal (0), duas linhas principais (1). 


\section{APÊNDICE III. MATRIZ TÁXON X CARÁTER}

A matriz resultante com a codificação de todos os táxons para todos caracteres é apresentada a seguir. Missing data são representados por “?”, polimorfismos estão delimitados por “[ ]”, enquanto dados não aplicáveis são representados por "N".

Adamantinasuchus navae

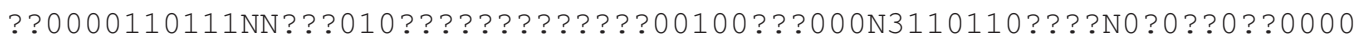

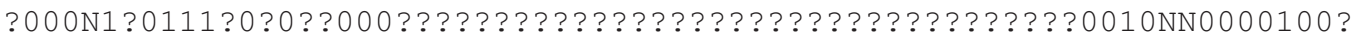

??10??0011?0110N01010N01000?0??2?1?111?0?????0?????????????????0??? ?N

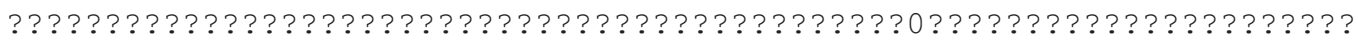

????????0???????????????????01100?0???01101 [12] 0??????1?1??000??00010

0???000N??????22210N00003101?001?00001011?????????????????????????

??????????????????????????????????????????????????????????????????0??

?110?0?00???00

Aegisuchus witmeri

11 ????????0???000??????????010111????????????????????????????0?????

?????1 ??0N??0????00??00101100000?10??? ?01000011000?0N100 ????????????

??????????????????????????????? 01 ??????????? $0 \mathrm{~N}$ ? 1 ? 21 ? $0 \mathrm{NN} 0$ ?? ?? ??????

??????????????????????????????????????????????????????? ?01 ?? 1100100

0 ??????00011000???110??110????????????????????????????????????????

????????????????????????????????????????????????????????????????????

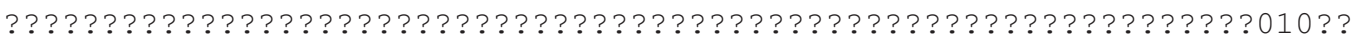
?01?00111??

Alligator mississipiensis

111001031001 NN0101101?0211001111100010010000N21100000100?0N0010200000 0100N1010N0101110100130101100010200100001100110N0000N000000NN10010010 N0000110?N01000N010 [12] 1101000N010201101010000?000N0101101000100?1010 01N100000010110100000110N01111200N020N0000N00100010010001001110001001 10NN0 $0000011010000100110011101011110000010001 ? 30000 ? 0$ N00000301?000000 
0011000010002000000 N0000100000021000010020110000101100001111100100000 010010101100000 ????1 ??010????10????01110??0?1???0???30N11111021010000 01100000001000

\section{Allodaposuchus precedens}

111000031 ? $0 ? ? 010110100011001010$ N00000?????0N21100000010N0 ? ?? 010000 ? 0000N1010N000101?000120101100000211????0110001[01] 001110100000NN????N 010N1? [01] ???00?????0N0 ?011101?0?N?10201101?1??0?0N0??0?02?010NN10010 01 ?? ?N0?000001?110?00000000N01111200N02????00N??1NN?10??0001??1?10?0? 00 ? $1 ? ?, 01000$ ? 101000010 ? ??0??10??????????????????????????????????

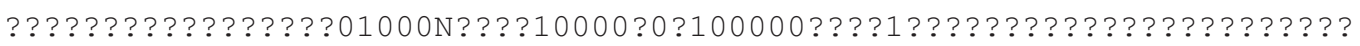
???????????????????????????????????????????????????????????????????? 0??010N?00??010??

\section{Amphicotilus lucasii}

111101031101 NN010110100211011010100000N?0111011110000110N0?0010?00000 $0100 \mathrm{~N} 1010 \mathrm{~N} 0101011000100101100000210100001100 ? 10 \mathrm{~N} 0110 \mathrm{~N} 000000 \mathrm{NN} 10 ? 10010$ N000??100N01000N0?011101001N010201?0101?000??00N0?00?0????10010110001

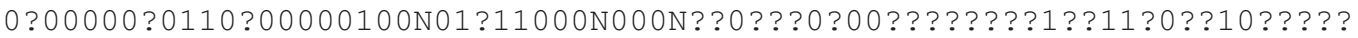

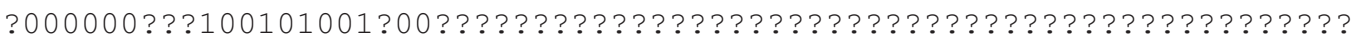
???????????00000N01001000010210000?002???????????????????????????? ????????????????????????????????????????????????????????????? ?00?00? ?000??010??

\section{Anatosuchus minor}

$11100103001021010010100210011011000000100000 N 31100000100$ N011N10100000 $0000 N 1011100010100001101010010101001 ? ? 0011000110111100000011100001010$ N10001100N0101??0?02110100010102110111100100N00N110110100010?1?01?0?N ??00000?1110000000000N01111000N01100000N0000?1?111000??01000001001100 00 ??1????0100011301110??101011110001??00101000?000N01??00021000010011 0001010001000000 N00000020000100?0000?00?01????????????????0????????? ?01???1??0?????????01?????????????????????????? $00 \mathrm{~N} 1100100$ ?? 1 ? 000011 $000000010 ? 0$ 


\section{Araripesuchus buitreaensis}

? [01] ?00111??1??0010?1?1202110?101??0???????00???11?0?00 ?10N0???10??? ???00?0N101??00?????000?0?100N?00101001?00???????????????0?0?????? 1 ?

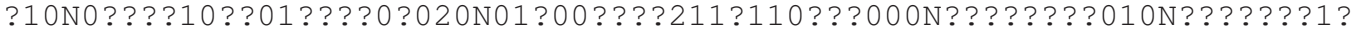

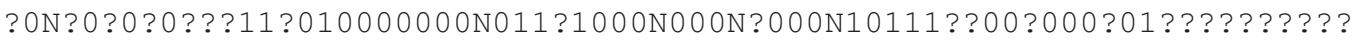
???????????1?????????????????10?????0??0[01] ?0?01[01] ?0??10N11?10 [01] 00 [01] 00100 ?0????????????? 1000 N?000?[0123] ?0???1?0??0??010????????? ???????????????????????????????????????????????????????????????????? ?? ??????????? ?0???1 ?? ?00????? ??

\section{Araripesuchus cf. Niger}

1010011100 ? [12] 0 ??????12021?0????? 00 ? 00100001231100 ?0001???1 ?????? ????????????????????????????????????? 1 ? 10 ???????????????? ? $000 \mathrm{NN} 1001$ ?

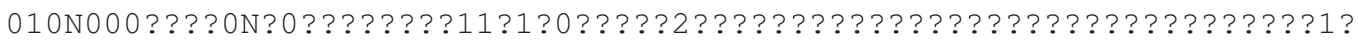
??????00???? 11 ?? 00 ? 000 ? 0 N01 ?? $1000 \mathrm{~N} 0010$ ??00N? 0000 ???????? ??????????? ?????????????????????????????10???? 00 ? 0 ? 00 ? 01 [123] ?1? ? 10 N11 ??000000?

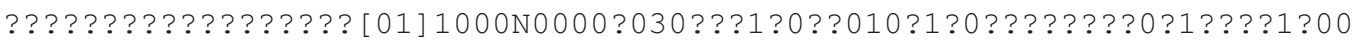
???????????01 0110 ?0 0?????????????????????????????????????????????? ????0???????????????0

\section{Araripesuchus gomesi}

$11100101001010010110120211001011100100100001231100000010 N 010000100000$ $0000 \mathrm{~N} 1000 \mathrm{~N} 0001010000120100 \mathrm{~N} 0$ [ 01$] 010 ? 001110011000110000100000010011011$ 010N00001100N0101??0002110100010102111110000000N00N11001010N01111?01? ? 0N1000000??110010000000N01111000N000N0000N001111?000000?0110000?1001 1000 ???10??10100011301?10?10010111030010[01] 00101100 ?000N11?110000?00 $1000111000 \mathrm{~N} 11101011000 \mathrm{~N} 00002030 ? 001100101001$ [01] 0??0??0?10?101??11001 ??1?101001011?110??0000100??1?????111011101111001???0?1?1?20N11000000 00000001100000001000

\section{Araripesuchus patagonicus}

11100 [01]?10?101001011012021001101110??0??00????31100000010N010000100 $0000000 \mathrm{~N} 1000 \mathrm{~N} 000$ ???0000120100N0101010011100??000110000100000??????001 
01 [ 01 ] ? 000 ?1100N0 [01] 01 ??00021001000100N211?110000000N00N1?001010N0??

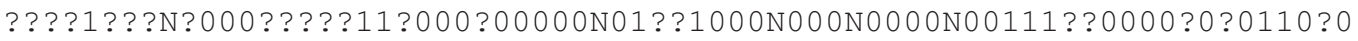
?010011000???10???01000113?1??0??0?10011030010?0?1???0??010N?1??00?00 0?00?00? 11000 N? 11010 ? 1000 N000020?0??0110??0?001???????????????????? ?????0??? 101 ??????????????????????11????0????? ?1??????? ? $20 \mathrm{~N} 1100000$ ? ?0000001??00?000?0?0

\section{Araripesuchus rattoides}

1110 ? 1 ? ?? 0 [012] 0 ???????????????????00??0100001231100?0001 ????????? ????????????????????????????????????????????????????????? ? 00101110 ?

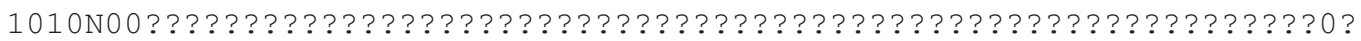
0??????????????????????????????????????????????????????????????????? ?????????????????????????????10?11?[01] 0 ??0?10?01 [123] ?1???? [01] 111 ? 0000 ?????????????????? $11000 \mathrm{~N} 0000$ [012] 0000 ???? ?010100?1 ?????????? ???????????????????????????????????????????????????????????????????? ???????????????????????????00

\section{Araripesuchus tsangatsangana}

111001110010100101101 ??2100110111?0?00??0001231100?00?10N0?1N00??000? 0000 N1 0 0 0N0 0 01010000130100N0001010011100??000110010??000000NN10011010 N0000?100N000????0021101000100N211111?0100000?0N110?1010N0?1?1?01?0?N

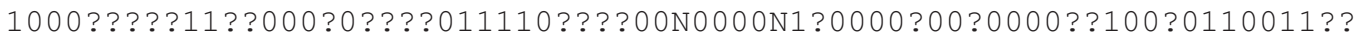
????1[01] ??10100011?01110?100100111000001?0101100?010N111[01] 00000000 0000 ?11001011101011000N0000 [12] 00 [01] ?001?0?101001000?0?1?110?111??11 00 ???110?100101??1101?00001??00101000?110111011110?110??????120N??0?? ??????000?11000?00010?0

\section{Araripesuchus wegneri}

11100101001020010110100210001011100100100001231100000110 N011N00100000 $0000 N 100110001010000100100 N 000101001100011000110001100000011111011010$ N0 0 0 ? 100 N01010N0002110100010102111110100000N00N11011010N01111101000N $100000 ? 10110010000000$ N01111000N000N0000N00100110010000011000001001100 ?000110010100011301110??10??01103001?010101110?0???0110000000001001?1 
?00101??01?11000N0000103000011001?100100???????10??????1100??????0?00

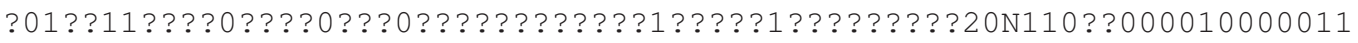
00000001000

\section{Armadillosuchus arrudai}

101000110 ? 11 NN021110????????1011?00??0???0?0N?110001011??0N???0200000 ? 000 N1000N000????000?20100N100?11011??001100?1101000N00001????????0?0 N1?????010???0????0?0N11000????211?111?001?0N0??1?00101?000??0?01???? ????????1????????????????????????????????????0??????????0?0?01100111

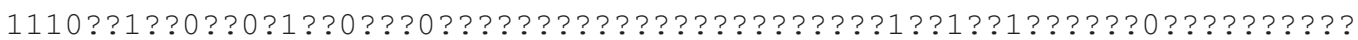
??????????? $2210 \mathrm{~N} 0111$ ??01?N0??1??01?110????????????????????????????? ????????0???????????????????????????????????????2? ? $0 \mathrm{~N} 001010$ ?? ?0? 0011 000 ?000????

\section{Ayllusuchus fernandezi}

111000 ? [01] 0??1N???????????????????100?0?0?01 [01] ??100??1 ?111????? ????? 0?????????????????????????????????????????? ?0???????????0? 110 ?? ?0??0??00?0 ?????????????????????????????????????????????????????? 11 ?

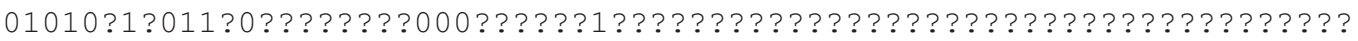
???????????????????????????????????????????????????????????????????? ??????????????????[01] 000 ???0?[01] [012] ?0???1?0?00?????????????????? ????????????????????????????????????????????????????????????????????

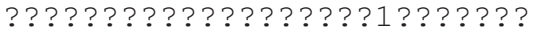

\section{Barinasuchus arveloi}

111000 ? 000 ? 0NN??????10101????????0000?0000011??100??1?11???????????? ????????????????????????????????????????????????????????0 ? $0 \mathrm{NN} 1$ ? ?0 ? 0 ? ?00????00N????????????????????????????????????????????????????0????

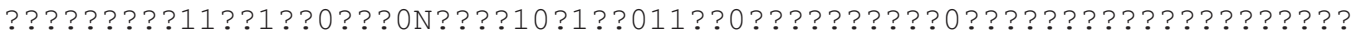

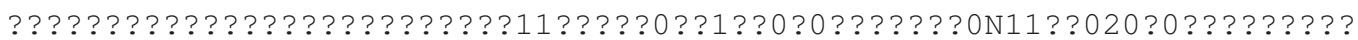
?????????? $11000 \mathrm{~N} 0000300$ ???01?0??0???11??????????????????????????? ???????????????????????????????????????????? ??????????????????????? ??????????? 


\section{Barreirosuchus fransciscoi}

11 ??0?????0???0101101000110110111????????????? ?00000? ?0N0 ?1N10100000 0 000N1010N00010?0000100100N000122001???01100110N0100N000???????????10 N?? 101100 N01000N01011011000N11?211?01??0000100??0?01100NN?11???????? ?00??1?0?11?000000000N01?11000N01100?00N001????101000101?1?00??00?1?? ??00000??0100011101?00???1?????????????????????????????????????????

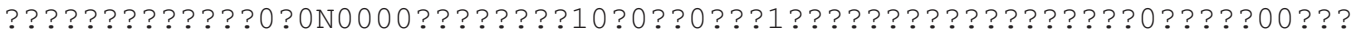
???????????????????????????????????????????????????????? ????? ? 000001 $1000000 ? 0 ? ?$

\section{Baurusuchus albertoi}

10 ????????1???02??1????????? 10211 ??????????????????????????????????? ??0??????????????0?0??01?0N????0?0111?001100011101????00????????0???? ???1??1?1111011101020N11000?10N2?10111000110N00N1?101111101?????????

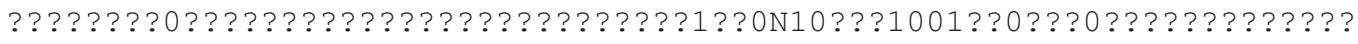
?100111??0?0???10???0???????0111000??0??1???0????????????????? 010 ? 01 $1000 N 100011$ ?????????????????????????? 10000 ?? 10011 ? 000 N0 ?? 01110 ? 00 ??1?011?1110111??01?1101111101011???10??0??1110??010112??00?00?00?1?1 0???000????

\section{Baurusuchus pachecoi}

101000000011 NN021110111?111010211?0000??100113110?01?10?N?N?????????0 ??0??????????????0?0??01?0N?1??000011??01100011101?1?1000111000001010 N0010?101111011001020N11000N10N2110111000110N00N11101111101111N01?000 $11111001011200101101111 N 1110 ? ? ? 100 N 1100 N 1000210011101110100101100 ? 1$ ? ??00111??0?000110?1100?10???0111?0011010100200001??1111121101?0010001 $0000 N 10001012000 N 00002300$ ? 1010000000011 ?????????????????0???????? ????????????????????????????????????????????????????????????? 0001 ? 1 $00000 ? 0 ? ? 00$

\section{Baurusuchus salgadoensis}

101000000011 NN020110111?110010211000000?? 01131100010100 N0N00N0111000 $1001111110101 ? 0 ? 0000110100 N 110010011110011000111011111000 ? 11000001010$ N00101101111011001?20N11000N10N2110111000110N00N11101111101111N0110?1 
$1101 ? 001011200101101111$ N1110???100N1100N100??1001110111010?1011001101 0100111 ??01000110?1?00??001101110001101010020000110111112110?00110?01 ?000N10001012000N0000230001010000000011???????????????????????? ??0 ?????????????????????????????????????????????????????2????? 0 ? 000111 $0000000100 ?$

\section{Bergisuchus dietrichbergi}

1110 ?0?0??1020??????????????????00????????????00??1 ?00N0?00001010?1

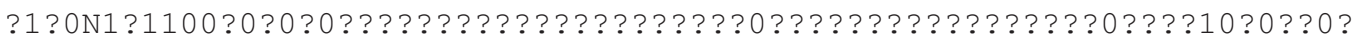

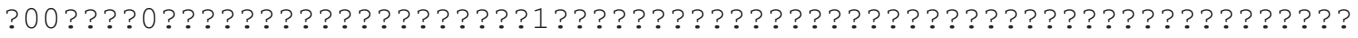

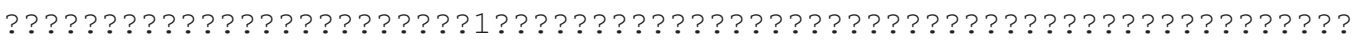
?????????????????????????????????0??? 00 ? 00??????? 1 ? 0 ?0 0 ? ?1 ??????? ??????????? $12000 \mathrm{~N}$ ? 010 ? ???????0000?0??1???????????????????????????? ???????????????????????????????????????????????????????????????0???? ?????????00

\section{Bernissatia fagesi}

111001031101 NN010110100?110?1011100000???0010 [23]1100000?10N010010110 $0000000 \mathrm{~N} 1010 \mathrm{~N} 000101$ ? 1001001011000 ? 0210 ?? ? $01100110 \mathrm{~N} 001$ ? ? 000000 NN0001? 01??0????100N?1?00N01??11010001?10201?01010?00??00N010?100NN?1?01101?

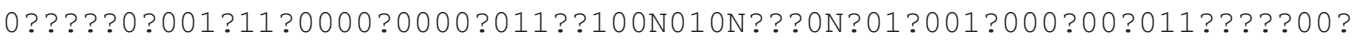

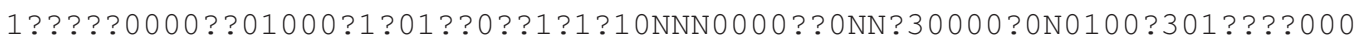
00011 N0010003000000N?1001000?0?21000010020??1?1??000?0????110??????00 ?1 ?0000????????????0???????? 1 ????? 111 ????????????2101100001111 ?000 $01 ? ? 00 ? 0 ? 01000$

\section{Bretesuchus bonapartei}

101000 ? 00011 N????????0101?0?????? 10 ? 00 ? 000113 ? 100 ??1 ? 1 ???????????? ??0???????????????????????????????????????????????????? 1 ? 110 ?? 0 ?? 1 00 ?????0111???0N0 ?0?0N??????????????1????????????????? $10 \mathrm{~N}$ ?? 1111110 ? 1 ? 00 ? 010 ?? 11 ? $010000010 N 111$ ?10010?10N?0?0N0?1???????001??111?????0???? ??????????????1????1???????? 11 ??10?? ?00?00 [23] ?0???0N1101020 [01] ?10? ? [01] 00 ???0???1?0??012000N00002000001100000 [01] 0011 ???????????????? 


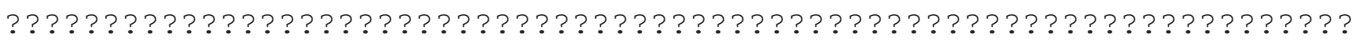
?????????????? 1 ???? ?0?

\section{Caipirasuchus paulistanus}

10100011011020010110111 [12]110????? ?00100N00000N11100000110N010010100 $0000000 N 101110001 ? ? 0000120100 N 10011100111001100011$ ?0?????000110000001 010N11000101111?00N0?000N11000010N21101111001?0N00N1?0??01???0?00001? 03N00000001?110000000000N111110100100N1?00N1002010011010110????0????

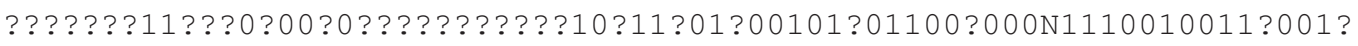

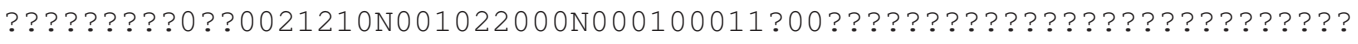

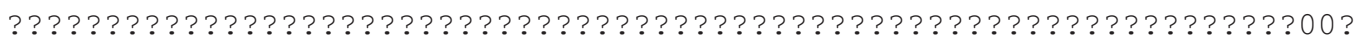
?1 ? ? 00 ? ?0? ?00

\section{Campinasuchus dinizi}

$101001 ? 00011$ NN021110111?1101102??00000001001121100?10 [01] 00N?N00?0??1 000100101 ??10?01???00001?0100N1100?1011110?11000111010???000111000000 010N0010?101101?11101020N11000N10N211?111?00110N10N1?101111001?1?N010 $0001101 ? 001$ ?11300101100101N1110110110N1?00N10?00??011101?1010????? 0 ? 1?1??????1??0?0001?0???00????11011100011???1 ?0200?01 ?011 ???2110 ??0010 ?? $10000 \mathrm{~N} 1$ ? ? $1012000 \mathrm{~N} 00002300010100$ ? 0000 ?11????????????????????????

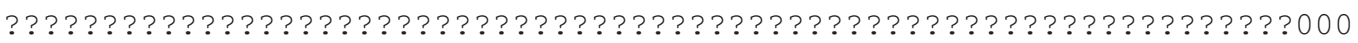
$11100000001 ? 0 ?$

\section{Candidodon itapecuruensis}

111001110 ? 020010000100 [12]111?1011?00??0???001 [02] 31100000?00N011N00

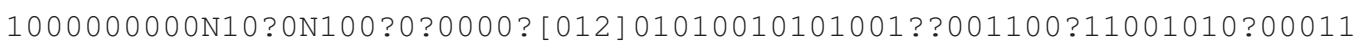

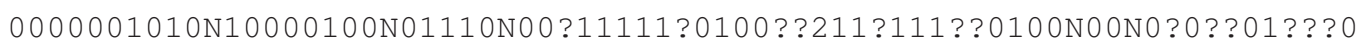
1???01???N?000?001?11??00?1?0?1001??1 [01] 00N000N1000N10000??001000101

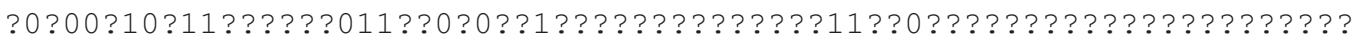

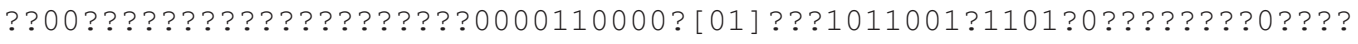

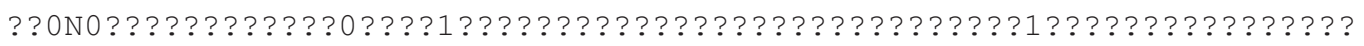
?? ? ? ? ? ? ? 00001 ? ?000 ? ?0? ? ? 


\section{Caryonosuchus pricei}

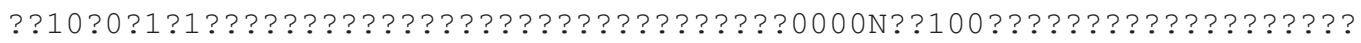

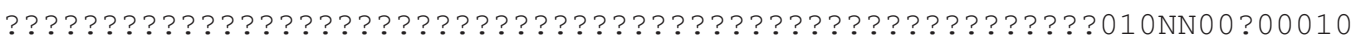
$\mathrm{N} 1$ ?????????????????????????????????????????????????????????????0????

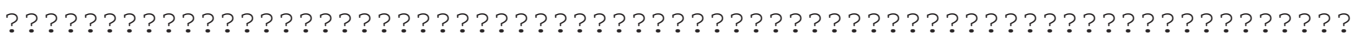

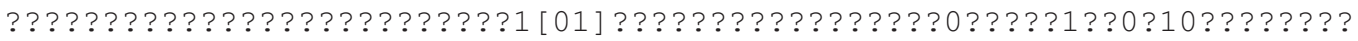
?????????????? $2210 \mathrm{~N} 0111$ ? [123] ?????? 1 ? 00 ?11???????????????????????

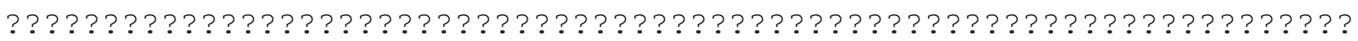
?? ?? ?? ?? ?? ? ? ?? ?

\section{Chimaerasuchus paradoxus}

101000 ?101?02??????????????????? 0000 N? 0001021100000110 ??11N???1 ???

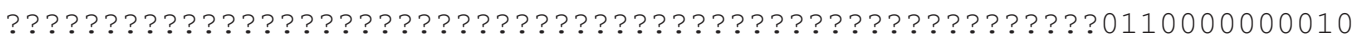
N101011?11??0??????????????1????????????????????????????????00010?0N

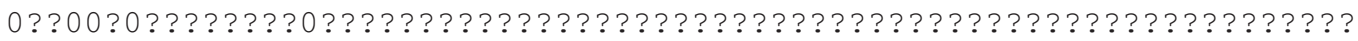
???????????????????????????? 11 ???????0?0? 10 ??????????0???1 ?? 0 ????? ?????1 [12] ?00?200011010144???N00?1 ?00?????0??1 ?0??10?10???1000??0????

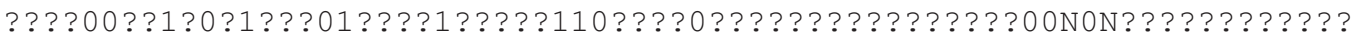
??? ?? ?? ? ? ???

\section{Comahuesuchus brachybuccalis}

101000130111 NN0 [12] ??1??11??00???????01?1N? [01] ?00N31100000010N0??? [0

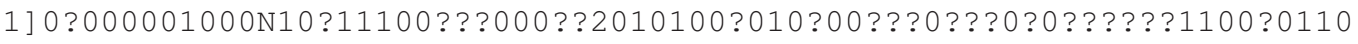
000 ? ??1 [01] ?1001??00N0?1 ?0N000?????0?0????????????????0N???1 ? ? 1 ? 100 ??1???01?02N1?000000?110000001011?111??????100N??????0???1?0100?0?10?

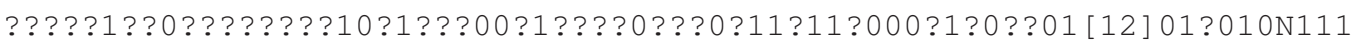
0000 [12]1??0????????00N??????01000N0?01 [12] 3 [12]1?00100000?0010????? ????????????????????????????????????????????????????????????????????

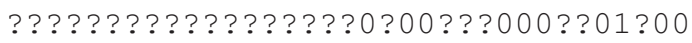

\section{Cricosaurus araucanensis}

0N0000021010210111011000?10?1001000010000000N01100000N110?0001010NN1? 1000 N1 010 N0 0000 ? 000020101 NN0 0100000 0NNN1 0N11 0 0NNNNN0N0110? 0NN00000010 
N?0100100N0001????020N111000???00000100?0000N???0??N000NN??00??010?0N

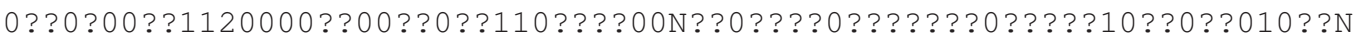
N???00???1100001?01 [01]11??11??00NNN0010000NN?0 ?0110??21000?000011100 ?00?0N0N?0?02000000N0000300000001?00?0?0000???????000???0?0N00?????01

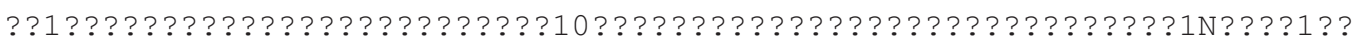
OO ONNO O? ? ? 0? 0

\section{Cricosaurus Colômbia}

0N0000021?1021010101??0????11001000???????00N0??00000N110000010 [12] ?N N101000N1010N000??? 0000 ?2101NN0 01010000 NNN1 0N01 ? 0NNNNN0N0100????00? ?

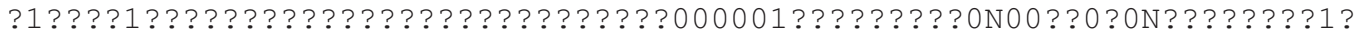
0 ?N0?000?0?? 11 ??0???0??0N0??1??????0????????????????????? 10 ? 0 ? 01000

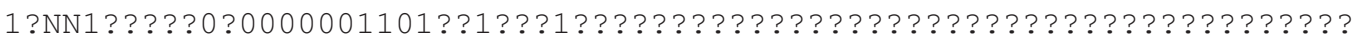

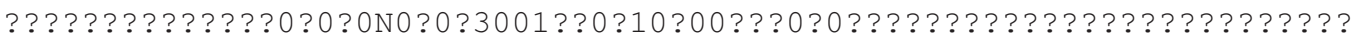

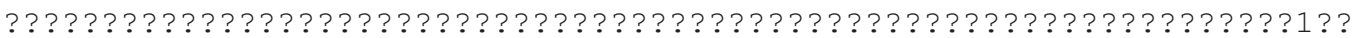
$00 ? ?$ ? $0 ? 0100 \mathrm{~N} ? ?$

\section{Cricosaurus schroederi}

0N0000?2??1021010101???????1????00??????????0? ?00000N11000001010NN10 1000 N1 010 N0 0 0 ? ? 000020 ? 01NN0?10? 0 ? 0NNN1 0N11 ? 0NNNNN0N011?????0000??10

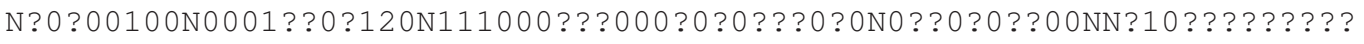

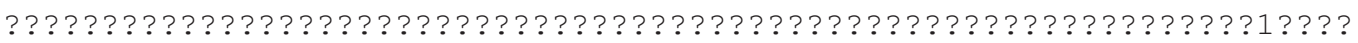

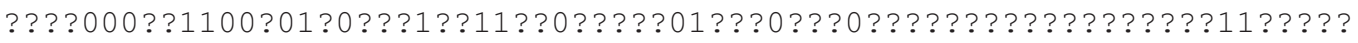

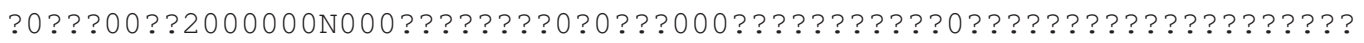
???????????????????????????????????????????????????????????????????? ?N0?????0??

\section{Cricosaurus suevicus}

0N000?02101021010101?????1 ???????00???00??00N011000??N11??0001??0NN1?

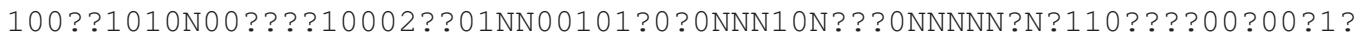

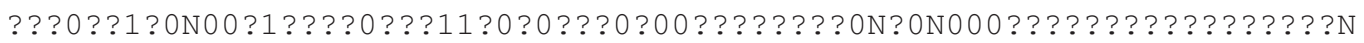
?????????????????????????????????0N???????????????????????????? 1 ???

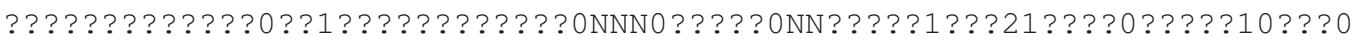




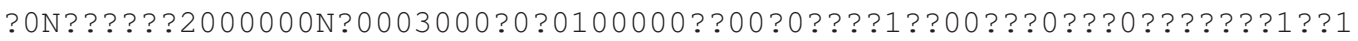
?0??? 1 ? 0 ? 10000 ???????????0?1?????????????????????????? $1 \mathrm{~N}$ ? ?N?????? ?N????0???0

\section{Cricosaurus vignaudi}

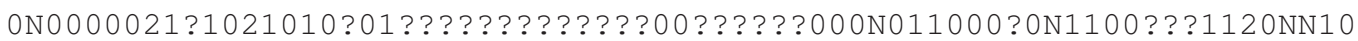

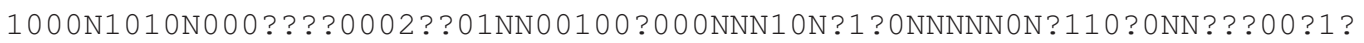

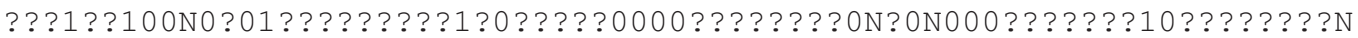
??????????????????????????????????????????????????????????????? 1 ?? ??

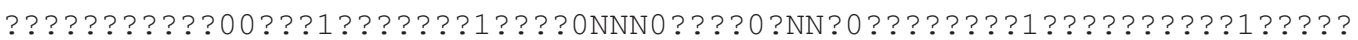
?0N???????0 000 ????0?30???0?0???0?????0?0???????0???????????????????

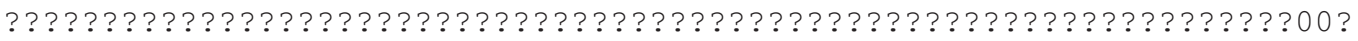
?N0????????

\section{Crocodylus}

111001031101 NN010110100011001111100010N000010 [23] 1100000110?0N0010000 $0000100 N 1010 N 0001110000130101100010200100001100110 N 00010000000 N N 10010$ 010N0 0 0 0100N01000N01011101000N0102011010100001100N010110100110011010 02N00000000011?100000000N01111200N020N0000N0010?010010001001110001000 10NN00000011010000100110011101011110000010001030000?0N0000030??000[01 ] $000010000010002100000 \mathrm{~N} 00001000000210000 ? 00201000101011000 ? 111110 ? ? 00$ $000010010101100000000110001010011000000111000001000010130 N 11111021010$ 00001100000001000

\section{Cynodontosuchus rothi}

10100 ?? 000 ?? ?N????????????0???????00 ?00????11???0???????N??????????? ??????????????0?????????????????????????????????????????0?100???0??1?

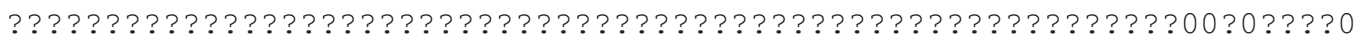

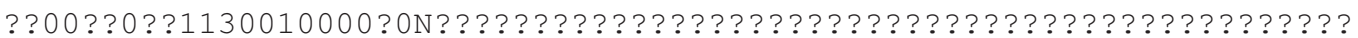
?????????????????????????????????0???????????0? 11011 ?? 2110 ????????

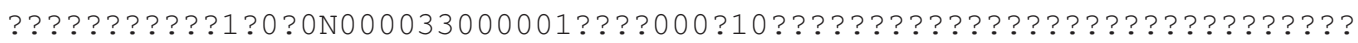
???????????????????????????????????????????????????????????????????? ???0??????? 


\section{Dakosaurus andiniensis}

0N000001??102101110110001??1100?0100?0N??000N01100000N11000001020NN10 1000 N1 010 N000?? ? 100020101 NN00100000 0NNN0 0N110 0NNNNN? ? 0000 ? ? ? 00100 ? 1 ? ?? 0000100 N0001???0120N01100010N00000100100?0N0??0? 0N00 0NN010???01?0?N

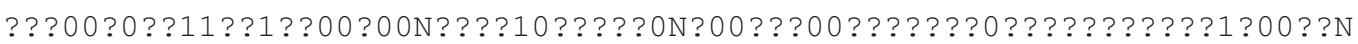
N???00??? 110000 ? 201 ?????? 1 ?? 00 NNN0 01 ?? 00 NN0010?0???1???? 11 ??? 1110 ?? 00 00N0N?0?0?? $12000 N 10003000$ ?0000?000000?0???0?01????????????????????? ???????????????????????????????????????????????????????? ????? ? 0 ?? 00 ? ?N0???010?0

\section{Dibothrosuchus elaphros}

ON0 000000010000201010 NNNN1 010N2 0N000000?0001131000000100N11??1010NN00

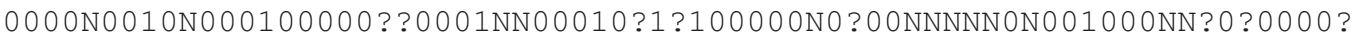
?? 0100100 N0 ? 00 ? ? 00110 N? ? 000100 N? ? ? 0100000 ? 0N? 0N0 0 0N0 0 0NNN100? 100 ? 0 ? 0

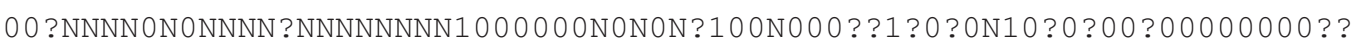
????0000100001??000?00?10?0N01100001010000??0000?0N00??0301??000000??

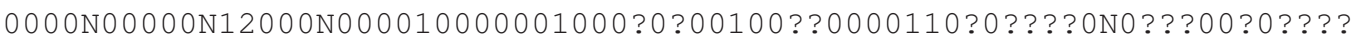
000 ?000?000000000??00???000?0010????0????????????0??11?00?????00N0000 NNONNN01NO?

\section{Doratodon carcharidens}

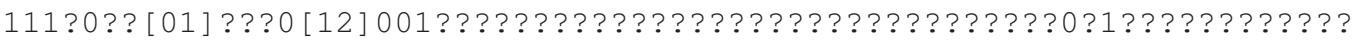

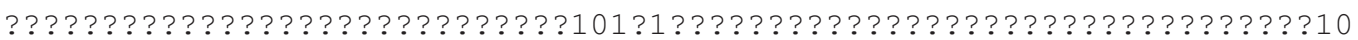
0???? $0 \mathrm{NO}$ ? 0??????????????????????????????????????????????????????????

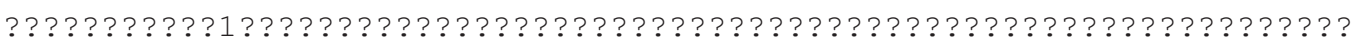
???????????????????????????????? 1110 NNN00 ?0?00N01310? ?00N111000000001 ?100??? $1 \mathrm{~N} 0 \mathrm{~N}$ ?????? $12000 \mathrm{~N} 0000$ ?0????? [12] 1000 ?000 [12] 00???????????????? 0??????????????????????????????????????????????????????? ??????????? ?? ??????????? ?? ?? ?? 01

\section{Doratodon ibericus}

??????????????????????????????????????????????????????????????????? ???????????????????????????????????????????????????????????????????? 
????????????????????????????????????????????????????????????????????

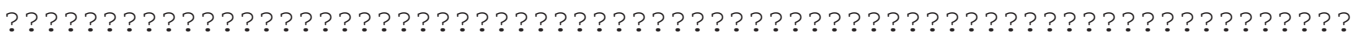

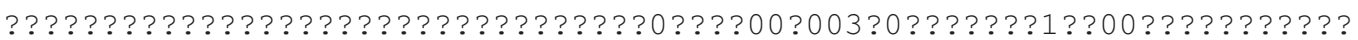

?????????? $12000 \mathrm{~N} 0000$ ???????????? 000 ???????????????????????????????

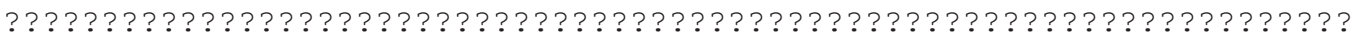

???????? ? 01

Dyrosauridae Bolívia

11111002 ?? 01 NN0111101 [01] 0??101101110?????????????00000?10N0? ?010000 $0000000 N 1010 N 0001001101100101000000200$ ??? ?01100110N0100N000?????1000? ?1110000?110N01000N00201101000?010101?0?0000000N0 0N0?00?00NN010????1? 0???000000101110000001?0N0?111?00N????1?00N0??????00?00??0???100??011 1000000000 ??011110130110????0110111000?1?00110000??00N211000000000?00 0 ????00N1 ?????00000N0000?0?????01010?000?0?????????????????????????

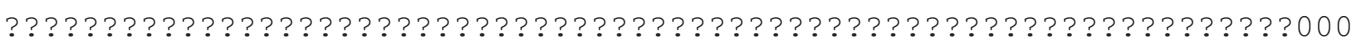
$010 \mathrm{~N} 000100100 ?$

\section{Dyrosaurus phosphaticus}

110000021101 N? 0111101 ? 0211011011101010 N? 0000 N1? 100010 ? 0 0N0? ? 010000000 0 ? 0N1010N000100100110?111000000?001???01100?10N0110N000000NN1000??11 1000 ? 0 ? 10 N? 1 ? 00 N01200N? 1000 N? 10101 ? 0 ? 00 ? 0 ? 0 0N0??010?10??N?1?0?001?0?? 00?000?1?111100000000N01??1100N000N??0???0000?101100010011?00?00111?0 1 ?? ?000?101101013?1100?010???10??001??001??0?0?0???21000?0??0??000?1? 1 ?00N???? $100000 \mathrm{~N} 0100$ ? 0000 ?0010100000?0??1??????0????????0????????? ???????????????????????????????????0???????????1???????????? 000011 $100010010 ? 0$

Elosuchidae (ROM) 11111002 ? ? 01 NN010110??????0?1011?0???????? ?N?1 ?00000?10N0 ?00 ?0?00000 0010 N10?0N?00????1011?0101100010?00????01100110N011???00?????1000??11

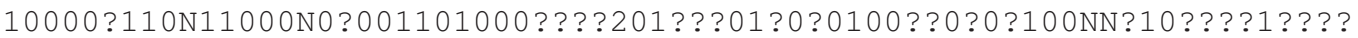
??000?0?? 11 ??0??????0N?????????????????????????????????????????????? ???????????00???????????????????????????????????????????????????????? 
???????????????????????????? 10 ? 0 ?????????????????????? ???????????

??????????????????????????????????????????????????????? ????? ?00 ?0?

?00???0????

\section{Eremosuchus elkoholicus}

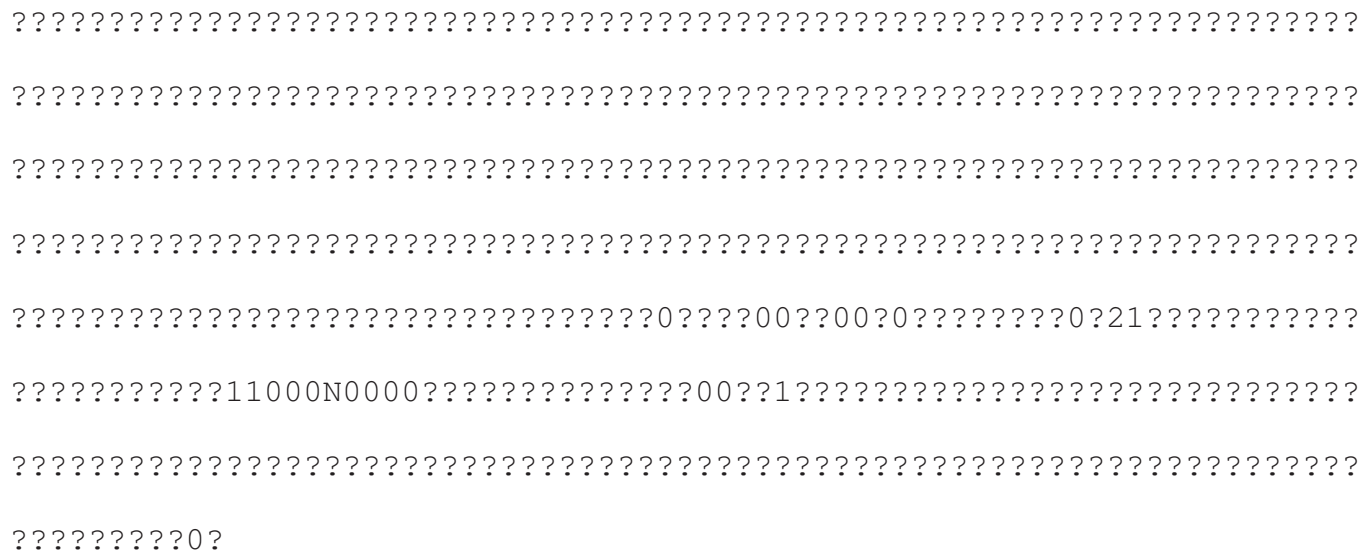

\section{Eutretauranosuchus delfisi}

11100103 ? 1002 N0101101002110110101000?0N???1??1?110000110N0?001010000? 0?00N1010N0101??1000100101100000200???001100110N0110N000?00NN1??????0 N0?0?0100N?100??01??11010?0??1020??0?0110001100N010010??N01?????100?? ??000000?10?100000100N?1011000N000N??00N?0100??00?0????011?00??0011?? ????00??1?1000010?1?00??1?111111000????00?10?0?0?0N11?00301?1000000?0 $0000 N ? ? ? 03000000 N 010$ ? 1000 ?00210000?0?20????????0?????????0????????? ?00???1?????????0????????????????????????????????2???????????? ? 0001 ? $? 0000001000$

Forma de Ingall

11 ??0?????002101011?1?0 [12] ?10?101110??????????????0?000??10010010100 $0000000 \mathrm{~N} 1000 \mathrm{~N} 00$ ?10100001001010000122001???0110011[01] ?01?????0?????? 0???10N??100100N0?0?0N010?10110??0???211001????0010?10???1?010N?????

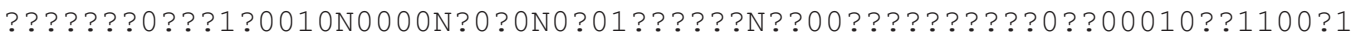
0001 ???1???????0100001?011?0???0???????????????????????????????????? ?????????????????01000N0000?0????? 10 ? 0 ??0?????????????????????????? ???????????????????????????????????????????? ??????????????????????? $0000011000 ? ? 010 ? ?$ 
Forma de Itaboraí

111000000 ?10 [12] 0010 ???1012101????????1?0?????????00?01 ???? ?1?? 0??

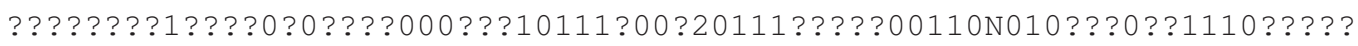
?1?????????0N???????????????????????????????????0??0???????????????? ?????0?????? 11 ?? 10 ? 000 ? 0 N0 ??? ?00???0????? 1010 ?0 ??????????????? ?? ???

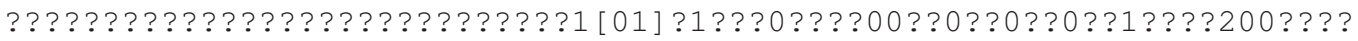
????????????????? $12000 \mathrm{~N} 0000$ ? 0 ???? 0 ?0?????? 1 ??????????????????????? ???????????????????????????????????????????????????????? ???????????? ??000??00????????

Forma do Maranhão

11100103 ? 001 NN0101001002110??????00000???0010 [23] 1100000 ?00N0N1N?0100

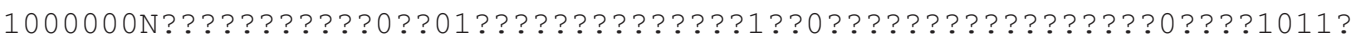
010N10101101001010N0?021?01001N0102?1?0?0100?00N0??0?0??01???1????01?

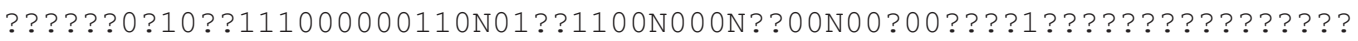
????????00??????????????????? $1010 \mathrm{NNN} 00$ ? 0 ?? ?N? ? 00 ?? ? $00 \mathrm{~N} 11$ ???? ?0 00 ? 000 00 ? $10 \mathrm{~N} 0 \mathrm{~N}$ ? 00 ? $3000000 \mathrm{~N} 01001000$ ?00100??00000?????????????????????????

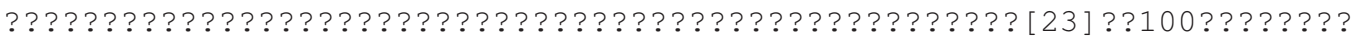
0????????0??0????

\section{Fruitachampsa callisoni}

111000110 ?11NN010100?0???00?0N2??00???????01131100?00010N0 ?01?02000?? 1 ? $00 \mathrm{~N} 10$ ? $0 \mathrm{~N} 00000 \mathrm{~N}$ ? $000100100 \mathrm{~N} 01010$ ?? 011100110 ?? 110001 ?? 0000 ???????01010 N000??00??00?0???0010N00??0????00100001000?0N?0N010?00110????0??0000? ??01???N?11??00100100N0111?000N01????10N?0???1?001010?00???????00????

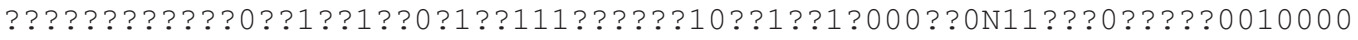
?000N??????02000N0000 [12] 0???1?1?0?100001110???00?01??????0N10?????0? ?1??0????0???????????????????1??????1 ??????????????? 211 ??0?????? ? 001 01 ??00???????0

\section{Gasparinisuchus peirosauroides}

1110000 [13] 0 ? 01 NN01????1?? [12] ?10??????00000?????1131100?00110N0N1N10 ????000000N10???00????0??????10??????0???1???????0?????????00 ?0011110 01 ? $110 \mathrm{~N} 00$ ?????????????0??????????N?????????????????????????????? 000 
01010 ???00010??110?000000?0N???1?????????????????????????????? 0 ? 0 ? 0 ?

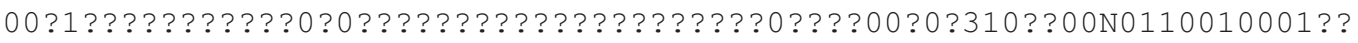

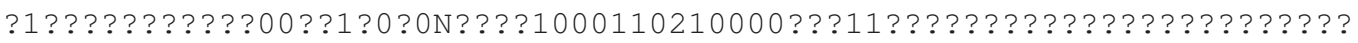
??????????????????????????????????????????????????????????????????? 0 ? 00 ? ? ?00000? 1 ? 0 ?

\section{Gavialis gangeticus}

111010021101 NN010110100011001111100010N?0000N01100000110?0N0010000000 0 010N1110N0001111100120101100010200100001100110N00010000000NN10010?10 N00 0?1110N01? 0 0N01011111000N0102011010100001100N0101100NN11001001002N 00000000011 [12] 100000000N01111200N020N0000N001??01001000100111000101? 10NN0000001001000?100110011101011110000?1000100000000N2100030??00 [01] $1000011100010002100000 \mathrm{~N} 01001000000010000000001010101111000 ? 1 ? 11100100$ 000 ?100000?110?0?????11??01?????100???01110??0?????????31011100011010 00001100000001000

\section{Gobiosuchus kielanae}

101000110010101 NN0 010 NNNN1010N21100000000001030100000100N0100?020??00 0000 [ [ 01$]$ ? 0 [01] ?0?010000?01N010NNNN? ?00001101N1000N1100110N100000NN?0

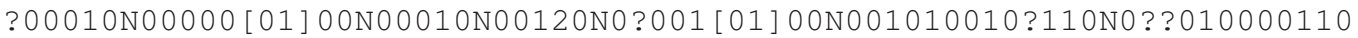
?10 [01] ?? 000 ? 0 ? ? 0000000 ? 0NNNNNNNNN?NN??? 11000 N0N0N0100N100?? ? 001 N0 0 ? 0N100000110?10?0???000??0??0001001?10??0???00NNN0010?01N010?00??0N?0? ?0301?000001?00?0N10?0010000000N00003000? [01] 001??10001010?1????????

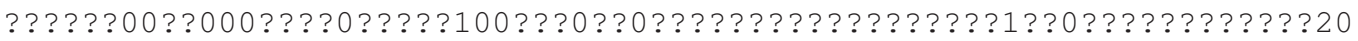
N1100?01?11100N010N00N0100???

\section{Goniopholis kiplingi}

111001031001 NN01011010021101???0100000N?0111011110000110N0?0010100000 $0100 \mathrm{~N} 1000 \mathrm{~N} 010$ ???1010?0010110000021010??01100110N0110N00000???10110010 N00011100N01000N?0?111?1000?0102011???1100?110??0?0?????N?10??0 [01] ??

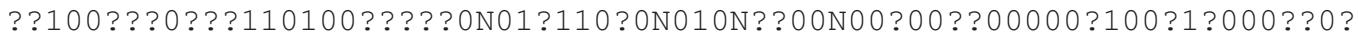
1 ????0000?? 01 ?0???0???00??????????????????????????????????????????? ??????????????00?00N010010000?0210?0000?2???????????????????????????? 


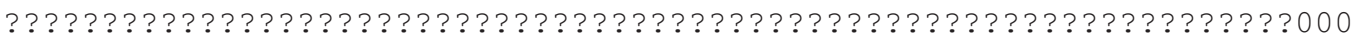
$001000 ? 0 ? 010 ? ?$

\section{Goniopholis simus}

111001031101 NN0001101002110?1010100000N?011101111000?110N??001?10??00 010 ??1000N01?10110101001011?000021010?001100110N0110N000000NN10110010 N00001100N0100??0?011101000?110201?01?1?00011?0N01??10?????0?1?[01]10

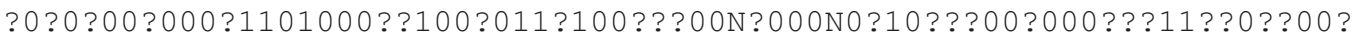
10 ?????00???0100001??1100??1???110110000?00?113???????010003?1?100100

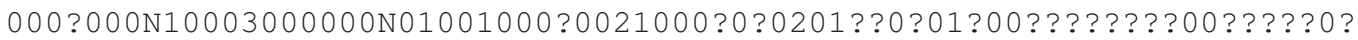

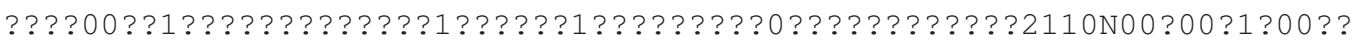
00 ? ?000??010?0

\section{Guarinisuchus munizi}

$111000021 ? 01 \mathrm{~N} ? 011110100211011011101010 \mathrm{~N} ? 0000 \mathrm{~N} 2 ? 100000100$ N0?0010000000 0000N1010N000???10011001110000012001???01100010N0100N000000NN10000011 1 ? 0000110 N0 0 0 0 ON0 0201101000 N0 0N1010010000000N00N010?10??N?1001001102? $00000011 ? 111 ? 00000000$ N01111100N000N1000N00000?00100001001110000011100 10 ? ?000? ?011010130??00??1 ?11?????00?0?0??????0?000N2110000001???0 ??? ???????????00000N0100 [12] 000 ? 00010100000 ?01?????? 10 ??????? 0? ?????

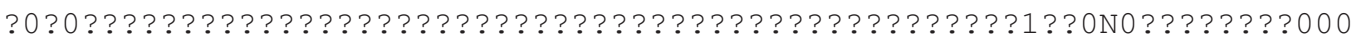
$01100001 ? 010 ? 0$

\section{Hamadasuchus rebouli}

$11100101001020010110100211001011110000101001121100000110 N 010010100000$ 0000N1000N00010100001101010000?0201????01100010N0100N0000111110011110 N00101100N11000N00010N010000011211?111100001000N01011010N010010010001 100001100112010000000 N01011000N010N0000N00100110000001011100001001100

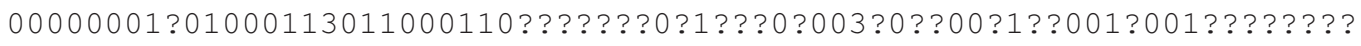

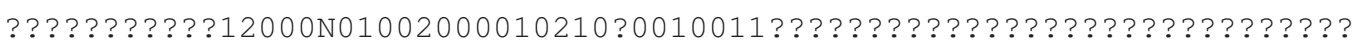
???????????????????????????????????????????????????????????? ? 000011 $1[01] 0000010 ? ?$ 


\section{Hemiprotosuchus leali}

? ? ? 000100 ? 10120100010 NNNN1 010N20N0 ? ? 0 ? 0 ? ? 000 N3 ? 100000100 N0 ? ? ? 0 ? 000 ? 0 ? 000 ? ? 0 ? 0N1 ? ? ? ? ? 0001 ? 0 ? 00 N00 ? 101 ? 011 ? ? ? 1000 ? 0NNNNN? ? ? 0000 ? ? ? 0 ? 0000 ? ??00??000N00??0N00100N00?0110??000001?0??1?0N0??0??000110?10????????

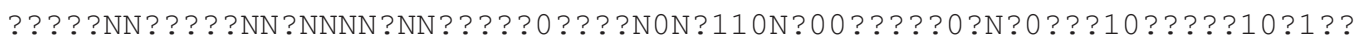

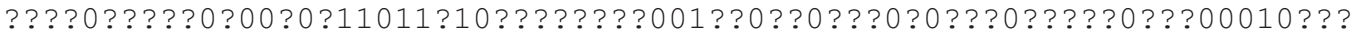
1000 N?0? 1001 ?0?0N?000?00???00????0??001????????0???????????????????? ??0??????000??????????????????????????????????? 211 ??0? ?00?1 ???? 0 ? 0 N?0N?1?0N?O

\section{Hsisosuchus}

1110 [01] 001??[01] 0100100111 N011001???11[01]000?[01] ??0010???10000?00N 01 ? ? 01000000 ? 000 N00 [01] 0N0000?N0000000100N000002001?00011000 [01] NNNNN 0N00? [01] 0???00?00????10?01100N00000N?0110N01?0000100110[01] 001?01?0N 0 0N0 ?0??0110?11??? [01] 0?0?????00?N??11??N?1?????N00??1000N11100100N00 00 ????0100???010?0?1000?1000000???0?0100111001?00??[01] ?111[01] ???001 ???1101?00?000N11??0?0?0?001000000000N?0003012000N0000?0?????100??0?0

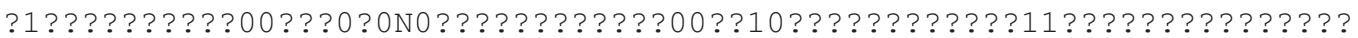
?????????????20N1100000?1??000000N00?01000?0

\section{Hylaeochampsa vectiana}

0N? 00 ????? 11 NN010??? 10001100 ?? 10 N0?????????????00000??0N0 ? 1 N00110000 ?00101000N1001010100110101100010200????0??00?10N00110100?????0??????

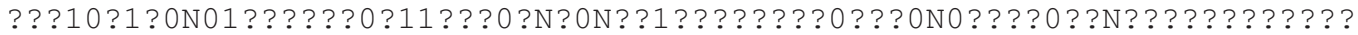
??0000 [01] ??110000?00000N01?11200N020N??00N011??010?100000?11?????00? 1????01???? 101000011011 ?0??10?????????????????????????????????????? ????????????? 0 ?? $00 \mathrm{~N}$ ? 0 ???????? 10 ? 0 ??????????????????????????????? ????????????????????????????????????????????????????????????????? 0 ?? $01 ? ? 00000010 ? ?$

\section{Hyposaurus rogersii}

111100021101 NN0111111????1??1 ?1??0100?N??0?0N???00 ?????0N0 ????0??0000 ? 000 N10? 0N000????101??00????000?200????01100010N0?10N?00000NN??00?? 11 


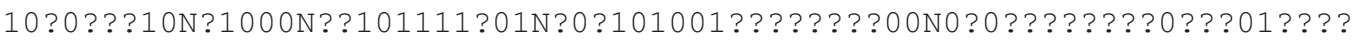

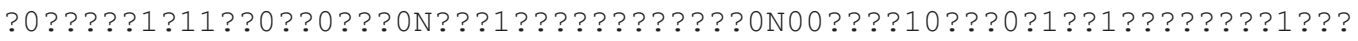

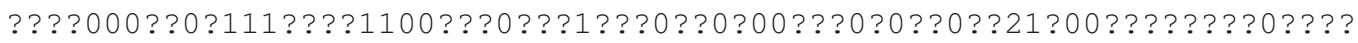
?0??????021000?0N???0?0?0????1010??????[01] ??????????????? 1100 ??????

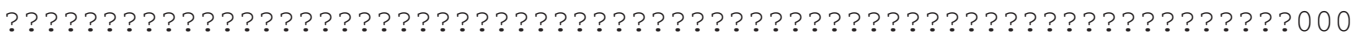
011000 ???0100?

\section{Iberosuchus macrodon}

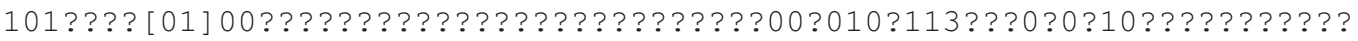
??????????? ?????????????????? ?????????????????? ???????? ?? 111001 ??? ????0???????????????????????????????????????????????????????????? 0 ? 0

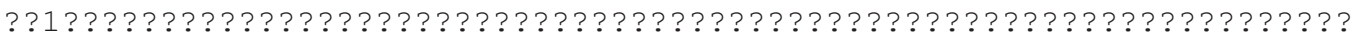
???????????????????????????????????????????????????????????????????? ????????????? 1 ? 0 ? $0 \mathrm{~N}$ ?? ? 1 ? 00100 ??0 ?00??0???????????????????????????? ???????????????????????????????????????????????????????? ??????????? ????? ?? ???? ??

\section{Iharkutosuchus makadii}

111000131111 NN1NN111100010011010N0 0000 NN? 0 ? 0N21100000110N0N1N? 0110000 0000 N1 000 N0 ? 0 ? ? ? 000 ?N01NNNNNNN0101? ?? ?011? 0N0NNNNN1 0100000 NN1 0 ? 0N010

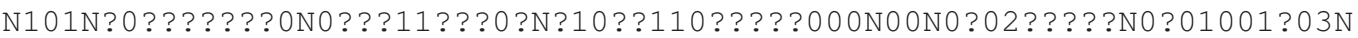
0 ? 000001 ? 110000000100 N01111200N020N??00N011NN010?100000??1?0???001101

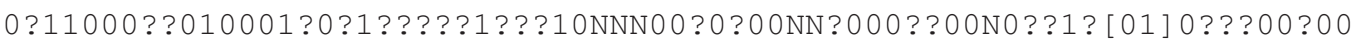
????0?0N??????000?1100001000000? 1100001 [01] 00 ?????????????????????? ??????????????????????????????????????????????????????????????????? 00 ?01???000011000

\section{Isisfordia duncani}

111000031101 NN01011010021100?? 11100000 NN0 0 0 0N21100000110N0?0000000000 0000 N1 000 N000???0000?10101100010200????01100?10N00110100000NN10000010 N0000?110N01010N01021101000N010201?010100001100N010?10????1?010010010 ? $0000001 ? 110100000100$ N01111200N020N??00N00100?1001000000111000?00?100 0 ?00000??0100001001?00??10???10?00?????00?0?0??0?????????????00????? 
???????????02000N010010000000?000000?0?1?00?11111?????11?10?????0??1?

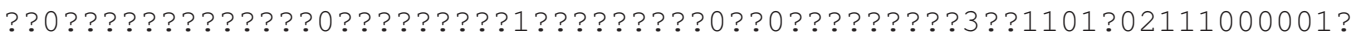
?00000010??

\section{Itasuchus jesuinoi}

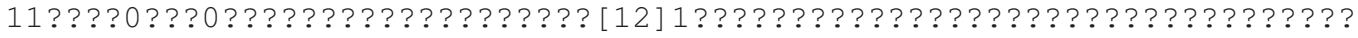
???????????????????????????????????????????????????????????????????? ??????????00N?1 ??0N0 ??? 1011000 ? 0112 ??????100?0? ?0 ??0?0??00NN?1?????? ??????????????????????????????????????????????? 11 ?? ????????????? ?? ????????0????????????????????1 [01] ?111?0????10?103?????0?1101?0000?0?

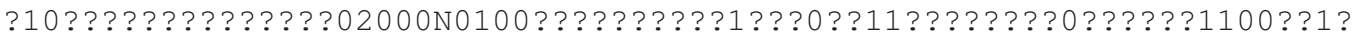

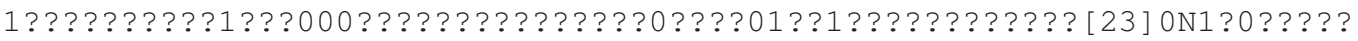
?? ????? 11 ???????? 10

\section{Kaprosuchus saharicus}

1010010310002102011010 ?2111????1100011010101021100010110N011N00100000 $0000 N 100100011 ? ? 0000 ? 10101010010201 ? ? ? 001100012$ N0111?000000NN0001?010 N0010N100N1101??10010N11010100N2110???110?00N00N0?0???????1011?11???1 ? ?000001?111010000000N01111100N01110000N000101?001000001110?00?00110? ??0000??????0?11??1?0???1?10111000010010100110?000N01?002011110111111 $1001010002002000 N 0000301001021000$ ?00?11??????????????????????????

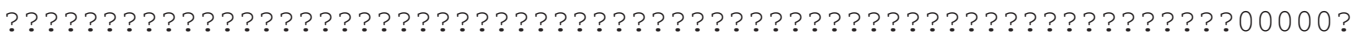
?000?0???00

\section{Khoratosuchus jintasakuli}

11000 ?????01NN01011?10001101???1?0???????????? ?00000? ?0N0N000000 ? 00 0000 N1010N00010?0?00?00101100010?00????0??00110N0110N10??????1??0??1? ?0?100100N0 ?0?0N?01?11??1??N???101??????????????0???????????????1 ?? N ??00000?? 111100000000 N01? 11100 N?10N???????0??????????????????? ?001100 0 ????????? 1000 ??0????????0??????????????????????????????????????????

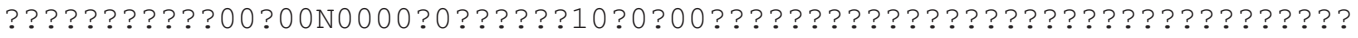
?????????????????????????????????????????????????????????????? 0 ? ?01 ?00010010?? 
Labidiosuchus amicum

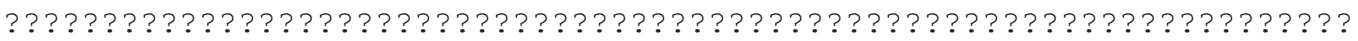
???????????????????????????????????????????????????????????????????

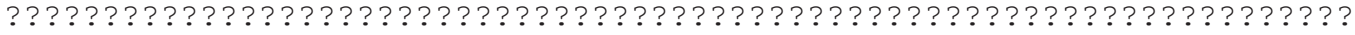

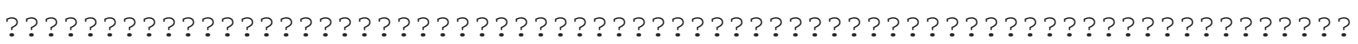

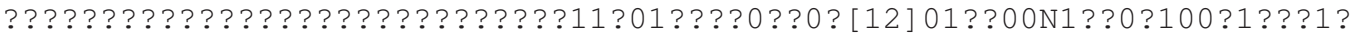
?????????????? 1 [ [12] $10 \mathrm{~N} 0001$ ??????????????????????????????????????? ???????????????????????????????????????????????????????????????????? ?? ???????????? ? 00

\section{Laganosuchus maghrebensis}

11 ????????0???000???101 [12] ?1?010111???????????????????????????????? ????????1??0N??0?????0??00101100000210????0110001100010N100?????????

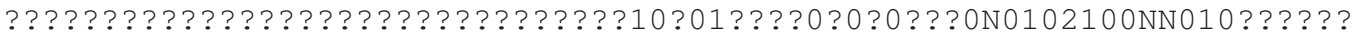

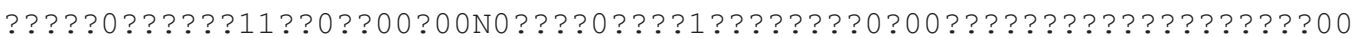
???????111??0110?0120110????00N1110[01] 00 ?0?00?100000?00N0000030110?1

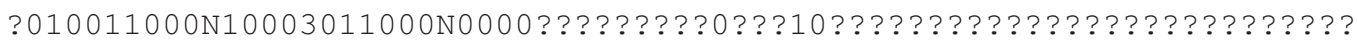
???????????????????????????????????????????????????????????????????? ?010???01???11100

\section{Libycosuchus brevirostris}

1 [01] ?0001100101001011010? [12]1?0????1100100100000N??1000?01?0N01???0 ?00000?000N10?0N?001???000?[23] 0100N00010100????0??000?????0?00000111 10000 ??1 [01] ?10?0?100N010?????0[12]100??00??10011????1?0100N???110?1?

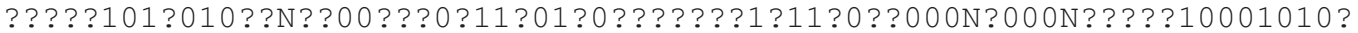
011 ???0??0011???????1???0100011?01?00??10???11030010?01?0?0 ?0? ?1 ? 0 ?? 002 ? 10 ? 01 ? 00010000 N100010??0?????? 0000 ? 1000001 ?????0????????????? ???0????11???0?????????????????????????????????????????????????????? ?????????0000???00?0?0?0?0

\section{Litargosuchus leptorhynchus}

0N000010000000010???????N??10N???000001??00??3??00000000N01001000NN00

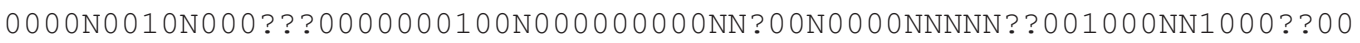




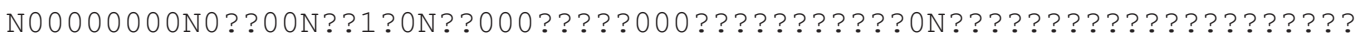

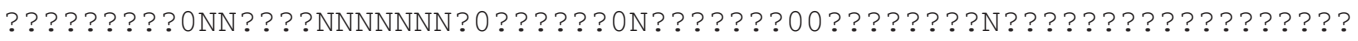

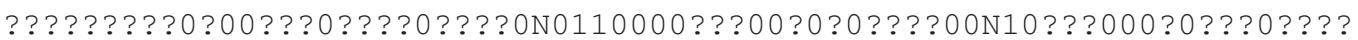

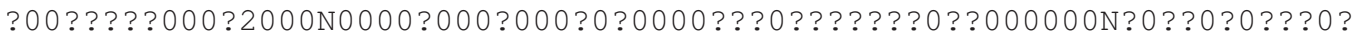

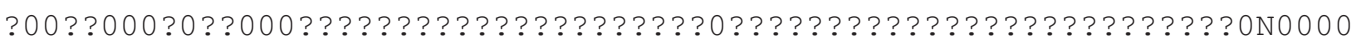
NO 0 ?NN????O

\section{Lomasuchus palpebrosus}

11100001 ??10200101101?02110110111000??????011 [23]1100?00110N011N00100 0000000 N1000N000101000010010100001010111010110001100110N0000????1001? 110N001??100N01000N0?01??0100010??211011110000??00N?1?1?010N0??????1? 1 [01] 110000100 ?11001000000??01111000N000N0000N0?1001100?01?1011000?01 00110000 ???? 11 ?1000113011?0???0??111????????0?00?10????????????? ?00

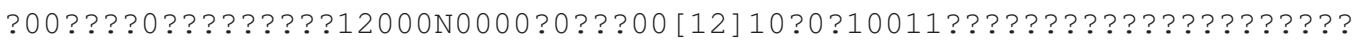
??????????????????????????????????????????????????????????????????? ? ???000001?00000?10??

\section{Lorosuchus nodosus}

111000031001 NN0101101002110????? 0101 ? 0001010 ?110000111100?0??00?00?? ? $000 \mathrm{N1} 0$ ?10000100?10?? [12] ?101110?1?2?????????????????????000?0NN???00 0110001 ?? $100 \mathrm{~N} 1100$ ??0?1 [01] 0N00000??1???1???010000??0??0?001?10N?1101? 010 ?001001?001?11001000?0?0N?10?10????0????01010?00 ??001????001????? ?0????????010???1??????01?00??1?11110021011??0?10????0?0N1100030 [01] ? 1????001??0?0N?0001001000N?0001000000100?001010??????????????????? ????????????????????????????????????????????????????????????????????? ?? ?0???0???0???0?00?

\section{Mahajangasuchus insignis}

$111000031 ? 0021020110110211011021100011$ ??1000N?1100010110N001N0?100000 $000101010 \mathrm{~N} 0011 ? 10100220101010012201$ ????01100012N0101010000???00011010 N0010N10 0N11010N10011111010100N2110110100000N0 0N010?100NN010???01002N $1000 ? 0010110110010100$ N01?11100N01110000N000101?0100000011100001001101 0???00?0?01000113011001110??111100010?101001???00??00000201?100111110 1?00N10?0?012000N0?00 [12] 000000110000001110 ???????1001110111011001100 
10 ?101?0?????00001??00111110?1101110111111?1????????010??0??00????000 00 ? ? ? 000011000

\section{Malawisuchus mwakasyungutiensis}

$101000110 ? 1010010110100110 ? 1 ? ? ? 1100100 ? ? 0001031100100110$ N01000 [ 01$] 000$ 0000000 N100110001???000 [01]20100N000101001?000??0001101?1??00001 [01]? ?000010100100?N000N01?0????010N01?00100N211011?0?0000N0110?0?1?100?11

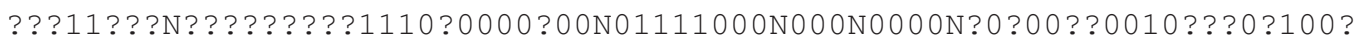
00 ?001???????01????10001?3??100??0?11?11??001??01[01] 0 ?000??10N11??01 000 ?? 00100011000 ? [ [12] 1010000011000021 ? ?100?001011010????????10?1???

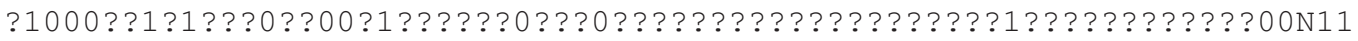
0? ?01????00?00??00?000?0?0

\section{Mariliasuchus amarali}

$10100 ? 110111$ NN0101? 01111 ? 0001021100100 N? 1000 N3110010001?N0?00?0200000 1000N1010N1?010?000012?100N01000100111001100?11010 [01]10000?1???000? [ $01] 010 \mathrm{~N} 10111001001100 \mathrm{~N} 0101$ ??01000?00N201011000000??0??1?0010110001 [01 ] ? $001 ? 00 \mathrm{~N} ? 00001011110000100010 \mathrm{~N} 111110000110 \mathrm{~N} 0000 \mathrm{~N} 100$ ? ?10?100001101000 00100111000 N?1?10?0100011301100??00100111010100?11?1?01?010N111??100? ?00010??01000N12?01021100N0110210101000000111??0??????????1???10???? ?11110????01?1???00?00011??0??????????????????????????????0???2???? ?? ?00001100000001000

\section{Mariliasuchus robustus}

101000110111 NN010????11??00110 [12] ??00?00N????0N3?1001000??N0????0??0 000 ?00???000N000????00????101[01] 0?0?0???1??????00?????? 1000 ? 0110000

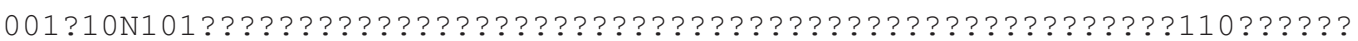

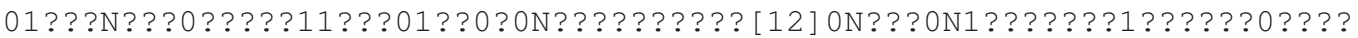
????????????????????00???????????? 11 ? 111 ? 1 ?? ? 01 ? ? 1 [12] ?1 ? ?? 111 ? 01 00 ???0?1??????????????? $21100 \mathrm{~N} 01102201$ ? 100 ? 0 ? 010 ?01???????????? 10 ????? ???????????????????????????????????????????????????????????????????? ??????0???1 ?? ??????? ? 0 


\section{Metriorhynchidae Áustria}

100000021010210101 ? $? 00$ ??101????0000100??000N01100000N1100?0011??NN10 1000 N1 000 N00 0 ? ? ? 0000 ? ? 101 NN00000000 0NNN0 0N11? 0NNNNN? ? 0000 ? 0NN0 0 ? 0001 ?

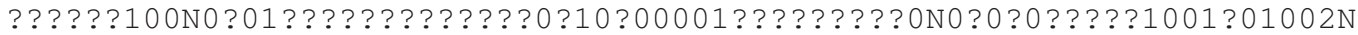

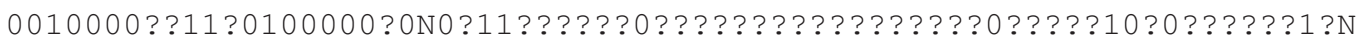
N1?? 000 ?? 1 ? 00001201 ?? 1 ?? 110 N0 0NNN0 ? ? 000 NN0 000 ? 000 N2100? 000 ????1? 0 ? ? 0 $00 N$ ?? 0 ?? 2002 ? $00 \mathrm{~N}$ ? 0003000000 ??00000000???????????????????????????? ?????????????????????????????????????0?????????????????? ????? ? 0 ?? 01 ? ?N00?101?00

\section{Metriorhynchus casamiquelai}

0N0 0? 0 02?110210111011001110?100?00?01?N??000N01100000N11?00001000NN1?

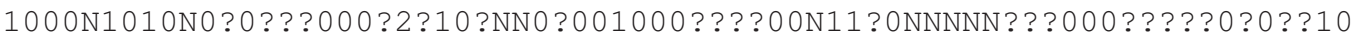

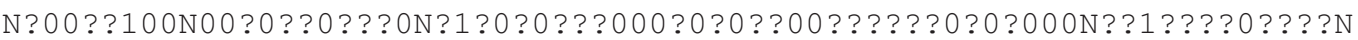
???0????? 11 ??????00?0N???? 10 ???? $10 \mathrm{~N}$ ?? 0 ??? 100 ??????0??????????????0? $\mathrm{N}$

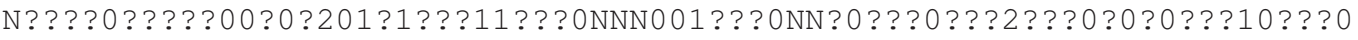

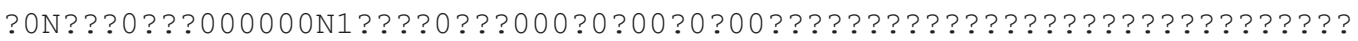
?????????????????????????????????????????????????????????????? 0 ?? 00 ? ?N0?? 10 ?? ?0

\section{Metriorhynchus superciliosum}

0N0? 000211102101 ?10?1?011??11001000010N?0000N01100?00N110000010?0NN10 1 ? 00 N1 0 ? 0N? 00 ? ? ? 000020101 NN0 0001000 0NNN0 0N11 0 0NNNNN0N0 00000 NN0 0 ? 00010 N?0?0?1?0N000????0??0N111000???000001?0?0000N???000N000NN0?001?01000N

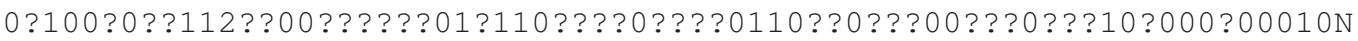
N0??000??1100001001111??11??00N??0010?00NN?00?100??210000000001100?00 00N0N00002? 10000 N000030000000??000000000??0????00??????0N00?????01?? 1 ????? 11 ????????????01?????0?1???? 1100 ??????????????????? $1 \mathrm{~N}$ ? $0 \mathrm{~N}$ ??? 01 ? ?N0???00000

\section{Miadanasuchus oblita}

11 ???????????????????????????????????????????????????????????0????? ???? 1 ??1 ??0???????????????????????????????????????????????????????? 
????????????????????????????????????????????????????????????????????

????????????????????????????????????????????????????????????????????

??????????????????????????10?????0??0?1???0??0? ?00N01 ?0?1010????????

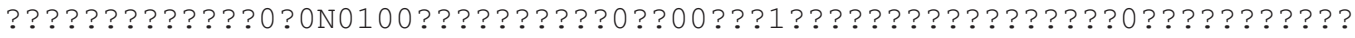

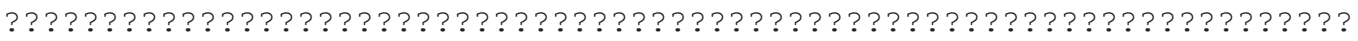

?? ??????0?

\section{Montealtosuchus arrudacamposi}

$1110000100102001011010021101101110000010 ? 001131100000100 N 011$ N00100000 0000 N1 0 0 0N0001010000?001010000?01011101011000110011100000111110011110 N00101100N01000N0101??0100010112110111100000N00N01011010N011001010001 $10 ? 001000112010000010$ N01111000N000N?000N00100?100100000110?0?01001100 $0000000100100011301100 ? ? 101111113001 ? 010100310 ? 01111110 ? 10001 ? 0110111$ $1000 \mathrm{~N} 10001012000 \mathrm{~N} 0000100011021000010$ ?11??????????????????????????

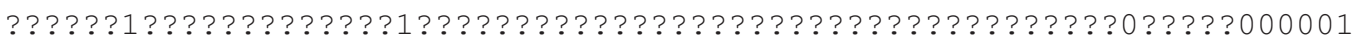
10000001000

\section{Morrinhosuchus luziae}

101 ?00?1011020??????????????????00 ?00N?? ?01221100000000N0100??? ?000? ??0????????????????????????????????????????????????????0110000011010 $\mathrm{N} 1$ ?0???0????????????????0???????????????????????????????????? 01 ? 0 ? $\mathrm{N}$

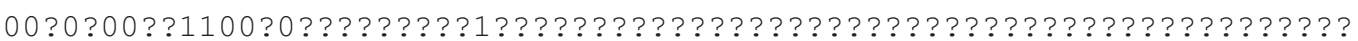
??????????????????????????10?11??1??01?1?01 [12] 0 ???00N111001000??0?1?

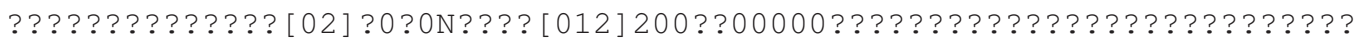
?????????0????????????????????????????????????????????????????? ?0??00 0???????????????????0

\section{Notosuchus terrestris}

10100011011010010110111110011021100100 N? 1000 N31100000010N010110000000 1000 N101110001000000120100N00000100111001100011010[01]100000[01]10000 00101 [01] ? 10001100 N01000N0?110N01000110N2110 [01]10?00000N00N110 [01] 10 110001 [01] 1?01000N?0000101?11?000100010N1N111000N100N0000N10000100111 $01 ? 10100001100010000 ? ? 110 ? 10100011301100 ? 10 ? 10011011010 ? 01101000 ? 000 \mathrm{~N}$ 
11100100100 [01] 0100011000 N?2101001100N00012100010000011010?00?11010?1 0110 ?1000001011110?00?0111? [01]10?110010011111?1111101111111101?100?? ????20N110?000???000001100000001000

\section{Orthosuchus strombergi}

111010110000100101000 NNNN0 010N20N01100100001130100000000N011N10100000 0 0 0 0N0010N1000??0000100100N000100001110010000 0NNNNN0N000100NN00001000 N1 0000000 N01? 0 ON0000 0N00001100N0000010000100N00N010?00110?N00?0000000 0 00 ONNNN1 ONNNN? NNNNNNNN0 01100 0N?N0N0 ? 0 0N0 0 0 ? ? 10000 N1010N1000110100110 01 ?????0?00000000?1??1??1?10111000010[01] 00001000 ??00N00100300?001?01 1001000N?0??0001000N00002 [34]00010000?00000000000?0??0000????0N0100?? ?00?00000?0??0?0??0000??010?00?101001000110??00????????2??0N0010000?0 01? 010N00N0100N00

\section{Pabwheshi pakistanensis}

10 ??????0????N???????????????????? ?0000? 10011 ?? ???0????N??????????? ??????????????????????????????????????????????????????? ? 111 ?? ????

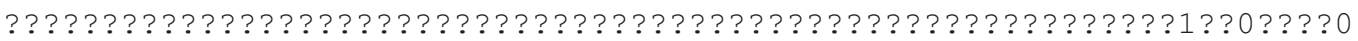
1 ?? 10 ? ?????????????????0?????????????????????????????????????????? ????????????????????????? 11 ??????? 0 ?????????? $10 \mathrm{~N}$ ? 1 ?? 10 ??????????

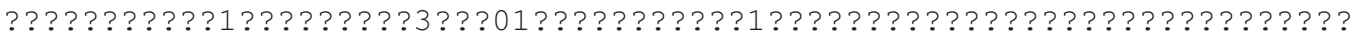
???????????????????????????????????????????????????????????????????? ?? ???????? ?

\section{Pakasuchus kaplimai}

101000110 ? 11 NN0101101? [01] 1???????110?????????0N??10?000 ??0N?N?000?0? ?000000N10?0N?001?0??0010010???00?11001?1001100?1100110N000?????00?0? ?10N1?011001??1010N??011011000?10N211??1?110000N00N??????????01????1?

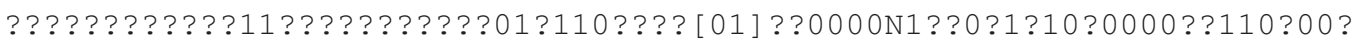

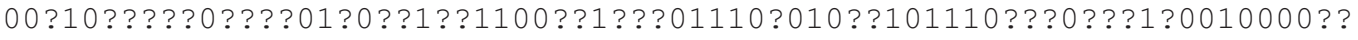
010 ? ?0 ?000N?210??0121110000?3 ???????N1 ?11121?000?10?10???????? ?0??? ???????0????????????????????????1????? 11 ???????????????? 11200000 ? 11 00 ? ? 1 ? ? 0 ? ? 0 ? 0 ? ? 
Pehuenchesuchus enderi

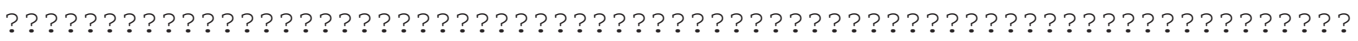

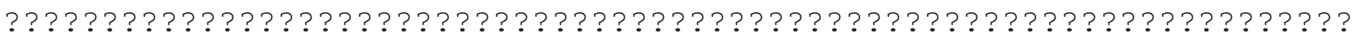

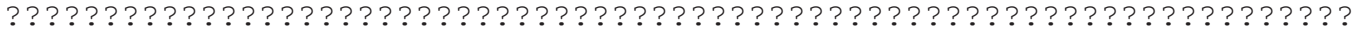

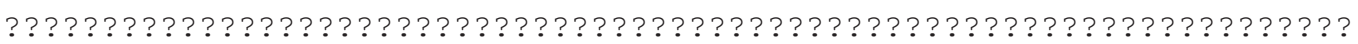

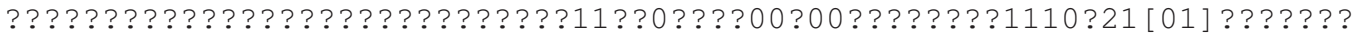

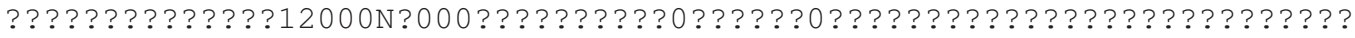

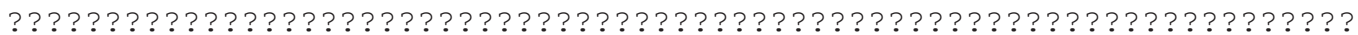
??????????? ?0 ?

\section{Peirosaurus torminni}

111 ?????00???????????????????????? 00 ? 100001131 ???????????????????? ?????????????????????????????????? 1 ? 00 ????????????????? 11111 ?????? ?????????????????????????????????????????????????????????? ?0000?0?01 ???????????????????????????????????????????????????????????????????? ???????????????????????????????????????????????????????????????????? ???????????1???0N????1 00110 ?????0100??1????????0?????? 1000 ??1 ?1???? ?????????000??????????????????????1??????????? [23 ] 0 ?11 ?????????? ?????????????

\section{Pelagosuchus typus}

111000021100200111011001111110010000 [01] 0N?000??01100000N11N01001 [01]

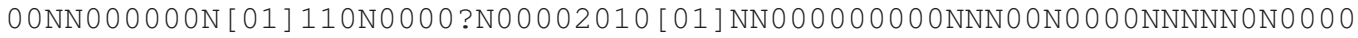
????00000?1[01] ?00000100N00?00N00010N10100100N0000010000000N0??000N00 0N??1001?01?0?N?0100001?112000000000N01?11000N000N [01] 00110000?100010 ?00 ?010?000101010NN100000001100001001011?011??011020010000??000??00?? 210?000???01100?000000N00?02000000N0000200000001000000000?00?????00??

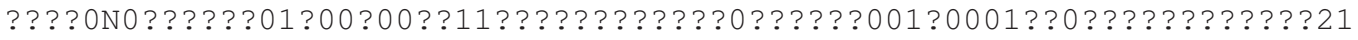
$11 ? 00000 ? 10 ? 0 ? ? 010 \mathrm{~N} 000 ? 1000 ? 0$

\section{Pepesuchus deiseae}

1111000 [23] $000021010110100111011011101100 ? 00001031100000 ? 10$ N010011000 $0000000 N 1011200010100001$ [01] 0101000012 [01] $001 ? ? 001100110 N 101100000010$ 01001 ?? $10 \mathrm{~N} 00001100 \mathrm{~N} 01000 \mathrm{~N} 010$ ? 10110000 ???2111111??00010?100101100NN?1? 
0??01?0?1?01001100112000000000N01111000N000N0000N000001100?0001011110 0 ?100?1000000?????0100011301??1???011?11??0??0?10?11010??00N110000000

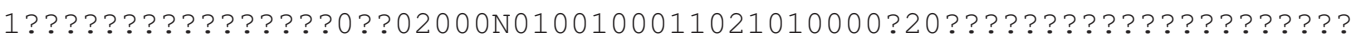

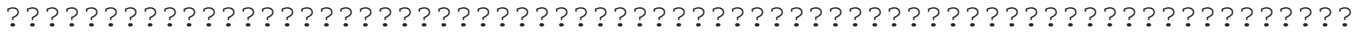
?? 00000110000001010

\section{Pholidosaurus pueberckensis}

111010 ?21101NN000111100 [12]11??1011101??1N????0N?1100000110N0???10000 $0000000 N 1$ ? 10 N0?0???1101100101000000210????01100?10N00?0N0000????10?00 01 ???00?000???1?0??????1111?0?N?10101??1??100?11???01??1?0N???0?1??1?

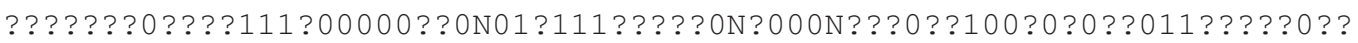
1??????00???01000?1?? 1100 ?01????????0????0????0??????, 2100 ?????0??0??

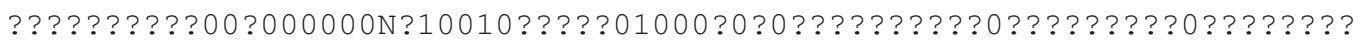

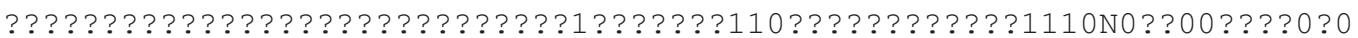
011000 ? [01] ?010??

\section{Pietraroiasuchus ormezzanoi}

1110001311 ????010111100210001010N00000NN? 0 0 0N21100000?10N0?1N?0110000 0000 N10 ? 0N000???0000?2?10110000?211????0??00?1 ??01110?0??00NN????N?10 N1 ?10?000? ?000????0111?100?N010201????1 ???????? ?0 ?02???? ?N1 ?? ? 01 ?? ?N

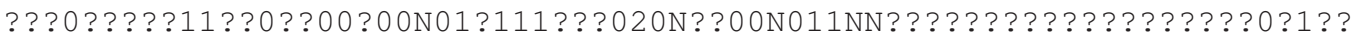

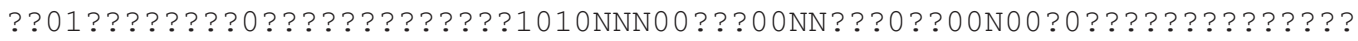

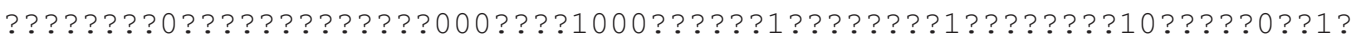
???????????????????????????????????????????????? $30 \mathrm{~N} 1001102$ ? 1 ??0? ?01 ??0 ?? ?01000

\section{Pissarrachampsa sera}

$10100 ? 000011$ NN0211101112110110211000000010011211000101??N1N00N1111000 100101011000100 N0000110100N11000101111001100011101?111000?11000000010 N00101101101011101020N11000N10N2110111000110N10N111011110011?1?01?0?? ?1111001111300101100101N1110110110N1100N10000100101011101001011101111 $11100100001000110 ? 1100$ ??0011?111?0?11000??0??0??110111102110????1???1 ??????????? $12000 \mathrm{~N} 000034$ ? 001 ? 10000000011 ???????????1??????0??0???????0 


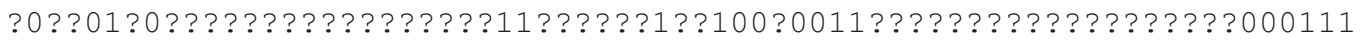
$0000000100 ?$

\section{Protosuchus haughtoni}

111010100010120100010 NNNN0 010N2 0N001000000011?0100000000N011N10100000 0 0 0 0N0010N100??? 0000100100 N0001000011000100000NNNNN0N000000NN00001000 N1 0000000 N01000N0?100N00001100N0000011000110N00N0?0?00110?10???0????

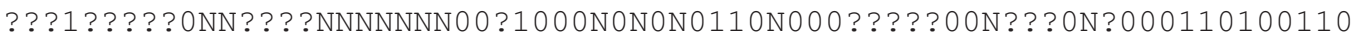
01 ??0??0??00000001101?????10110040010?01101100??00N00??0200?0000100?0 ?000N0?? 10012000 N00002000?100?0?0000?010000???1 ??00????11?10?0?0????

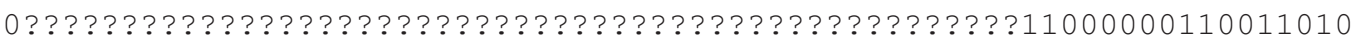
NOON2100N?O

\section{Protosuchus richardsoni}

11101010001012010 ? 0 ? 0NNNN? ? ? N20N00? 0 ? 0000011301000000 ? ?N01??00?00000 0 0 0 0N000 0N1000??0000100100N000100?0110001000? 0NNNNN0N00000 0NN00001000 N10?0?000N? 1000 N?? 100 N0000?10??00?00??000110N?0N010?00110??0?0?00?0??

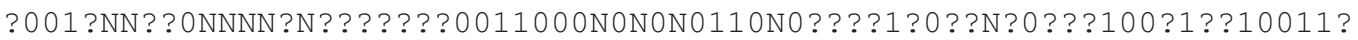
????00???0?000?0?110110110???10040010?011010000????100?0?00?00001?010

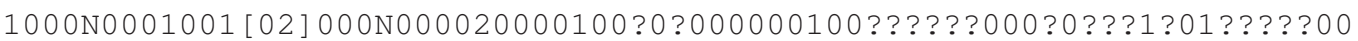
??0000??1000??00000???00???00010010000N0000??000100021111000000110?11 0???00?2?????0

\section{Purranisaurus westermani}

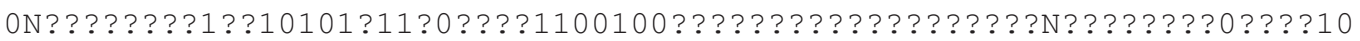

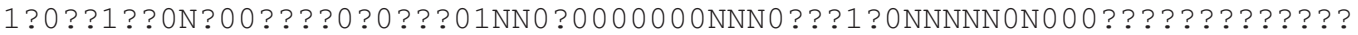

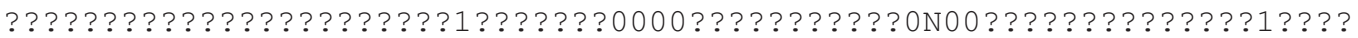

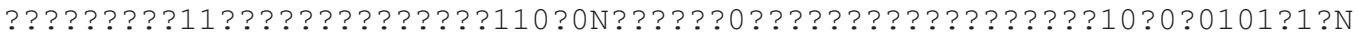
N??????? 0000001201 ??1 ? 11 ?????????????????????????????????????????

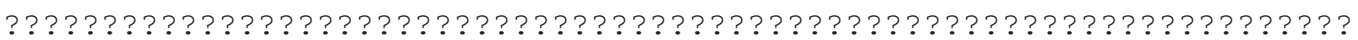
????????????????????????????????????????????????????????????????? ?1 ?N0??101N?? 


\section{Racheosaurus gracilis}

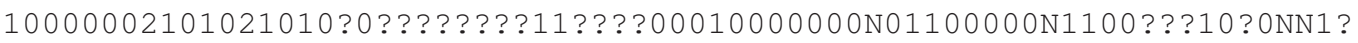

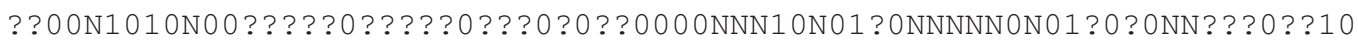
N?01???????0????????0????0?????????0??????00N?????0??????? 1 ? ?? 0 ? ???

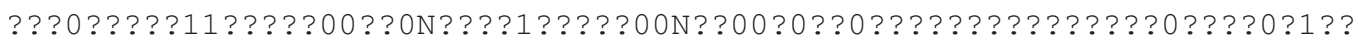

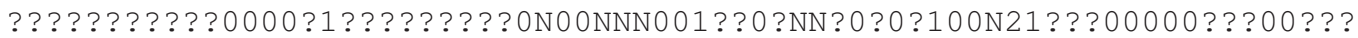
? ONON?0?02000000N0???3000???? ?0?000?00?0?????? ?0000000?0N000?00001??1

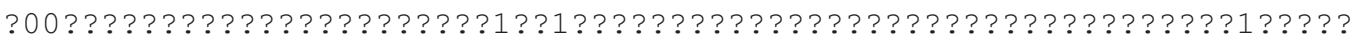
?N0?? 1 ?00?0

\section{Rugosuchus nonganensis}

111001031 ? 01 NN0101101?00?10?1 [01] ?0N00????????0N21100000000N0N???0??? ?0???00N10?12?00????100?0?10110?0002?0????0??00110N1110N000000NN???1? 010 N0?001100N01?0?????11101000N?102????1?1?0????0???10?1?????10???01? ?????00000?? 110000000110 N011111???00???000N00????????????0??1?????001 1000 ? ??000? ?010000?0010?????01110NNN0000?00NN00 ?0??00N01??03010??00?? $00001 \mathrm{~N} 1110003000000 \mathrm{~N} 00001000000210$ ?0010?0?0??????????????????????00 ??????????????????????????????????????????????????? [2 1110100 ??????? ?0001??10000010?0

\section{Sarcosuchus imperator}

111000031101 NN0101111002110?1011101011N?00?0N11100000110N0?00 [01] 0000 0000010 N1010N0001001101?00101100010200????01100010N0010N000100NN?0000 010N [ 01$] 0000110$ N01000N01101101000N0101011010100001000N0?01100NN?100?0 $11102 ? 00000000 ? 111100000100$ N0?1?1100N010N0?00N001?0?100100010011?0??1 00 ???00???000??0100001?01?00?01???110100010?00111[012] 00000??21000?01 01001000001000 N?00?2000000N01001010011000000000211????????0?000????00 0 ? 1000 ?? ?000???????????????????????1?0??? 111 ???????????? ?111 [01] ?0? $000 ? 1 ? ? 00001 ? ? 0000001000$

\section{Sebecus huilensis}

1110 ? 0 ?000?????????????????????1 ??000?00000113?1?0?0111?N???????????

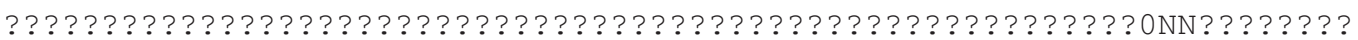




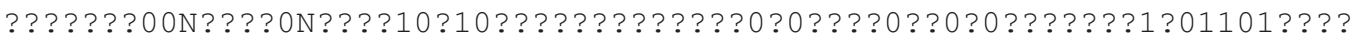
??0?0?0?????????????????????????????????????????????????????????????

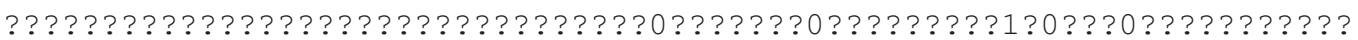
1?????0001012000N?0?0 [1234] 00 ??????0000????1???????????????????????

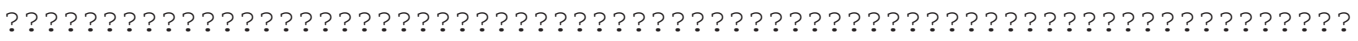
?? ?? ???? ? ? ? ? 0 ?

\section{Sebecus icaeorhinus}

11100000 ??11NN010110101010??101111?00?0??0010??100001??110?00?0100000 ??00N10110000????00?1 [01] 0101110??010?1?00011000110011??000??0NN1000? ? 01000001100 N? 1000 N00111001000?0112?1??1?100000N00?01001010N111?? ? 01 ? ??1100001???1100100000?0N????10???00???00100????01000?00001???0001001 1 ?00?00000??0100001001100?110???111?001??00?01[02] ???0???1100?10 [01] ? ?001?0?10?001010001?12000N?000 [01] 00?00?110000101010??0??0?1001110?11 0010001 ?01???????1??01?11010?11??101??1100111?11011?101111010???????? ??????000001010??001000

\section{Sebecus querejazus}

111000 ? 0 ? 11 N??????? 1012101 ??????0?????????????00001?10N0 ?0000101001 ?100N101100?0100??0???????????????????0??????????????????????1000??01 $000100100 N$ ? 10 ? 0 N000? 10010 ??????2????????????????????????????? 1 ? 0 ?? ?000?1???11?010000010N01??10011000N?00100?1?011001000001?1?????????? ????????????????????????????????????????????????????????????????????

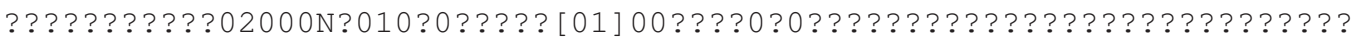
??????????????????????????????????????????????????????????????????0?? ?0???0100?????

\section{Shamosuchus djadochtaensis}

11100113 ? ? 01 NN01011010?011001010N000??????00N?1100000110N0N1N00010100 $0000 N 1001200010 ? 0100100101100000210$ ???001100110N0110N0000????10010010 N00001101N0101??01011101000N0102010111100001?01N010110100110??????0?? ???0??0??11??0??00110N01111100N000N0000N001??1?001000?001110?01001100 0? 000 ??? 10100001001000 ?1101010NNN000?000NN?? 0?? ?00N01??0[03] 0?0000000 $00000 \mathrm{~N} 1110003000000 \mathrm{~N} 000$ ? [123] 0????0110?00?001? [01] 0?0000111?0????111? 


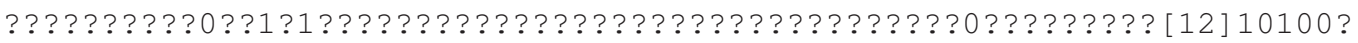
????1?1000011010?00010??

\section{Shantungosuchus}

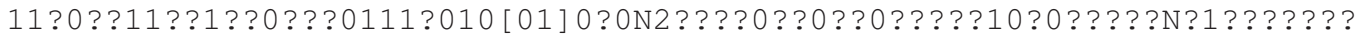

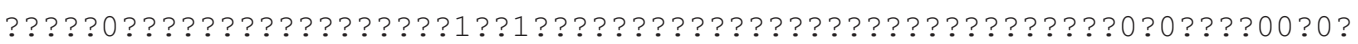

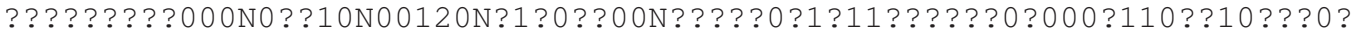
????? 0100 N? ?10 ?NNNN????NN????1000N0N0N01 [01] 0N100??1?0???100?010?0011

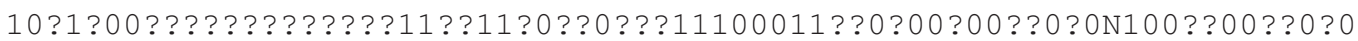
?? ?0?00? 110 ?? ?00?0?0?0N?000????0??? ?000?00111?0?????????????????????

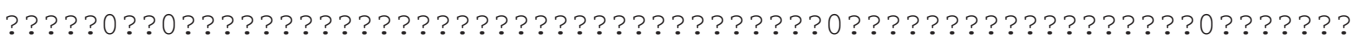
?????0N??0010??0?

\section{Sichuanosuchus}

1 [01] $1000110 ? 1010010011100$ ?000????1?000?00??0011?1100000?10N010[01]10 20000??000N [01] 0111000 ???000?1?0100N0???00001100011000110001??0000??? ?01?0?01???00?0000N?001??00120N01?0110 [01] ?0?1?10?0?1100N0??0?0?0011?

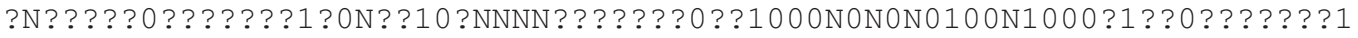
0?001110?1?000??10?????????1??1?1???0?1011100011??01?01000?0?0N10??00 0????00?1??0001?????0?00?0?0N00002000?0011??00?0?11?????????0????? ? $\mathrm{N}$

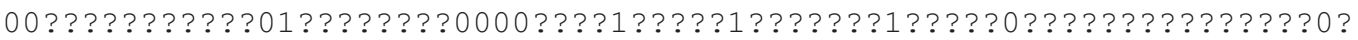
??????00?010N00?010????

\section{Simosuchus clarki}

101000130010100100101 [01]121??0102100001100 [01] 000N3110N0000N0N010000 0000000000 N1001001010[01] $0000220100 N 100000001100011000110111101000110$ 10000101 [01] ?1000?100N00010N01020N0100000100111111100100N0111?0110100 00001100002 N1 000 N?N1010NN1 0 0NN? ?NN01011000000101000N10010100010101N? $00000100010100 ? ? 110 ? ? 01000113011000 ? 1010111100110001101000$ ?010N011002 02N000110001000101010100200100000102000000001010[01] ?0?0110[01]0010?1 0???11001???100?0?10100100001000100011?100010??????1111???00010111130 N110?1020111000010N0000001000 


\section{Sphagesaurus huenei}

101000110111 NN0? ?1101??2110???????0100N?00 ?0N11100000110N???????0??? ?00???????????????0??????????????0????????????? ?? 0 ??? ? 00110000001010 N11000101111100N01000N01000?10N2??011?1000?0N???1?????1100?100001000N 00000001 ?110000000010N?11110?00?00N1000N???001?0?1?1?1??100000100?111

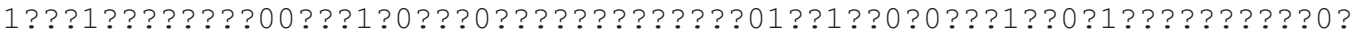
???????????21210N011142000N0001?00111?0?1?10?0???1?????????????????? ???????????????????????????????????????????????????????????????0??? 1 $0000000 ? ? 0 ?$

\section{Sphagesaurus montealtensis}

10100011011020010110111211011011100100 N?? 000 N?1100000110N010010100000 $0000 N 10111000 ? ? ? 0000 ? 20100$ N? $00 ? 110011100110001100000 N 0000110000001010$ N11100101111100N01010N1100001??211?111100000N00N??0?101?0??? [01] ??01? 03N00000001?1100000000?0N1111101?0100N1000N10020?001101011010??001??? 1???????????0?00?1?001?00??0010?11?01??1?01101100?000N1110010011?001?

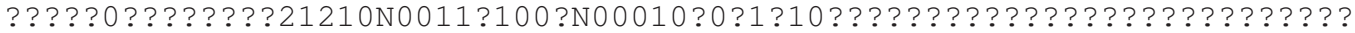
?????????????????????????????????????????????????????????????????? 0 ?? ?1???00? ?0? ?00

\section{Sphenosuchus acutus}

ON0 00010001000010101 0NNNN1 010N2 0N0 $000000 ? 001031000000000$ N01001000NN00 0000 N0 010 N0 000 ? ? 00000101 NN0 0001000 0NN0 0 0N0 0 0 NNNNN0N0 01000 NN1 0001000

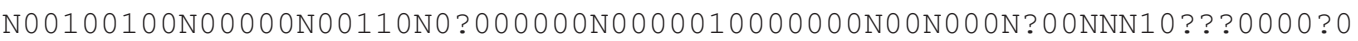

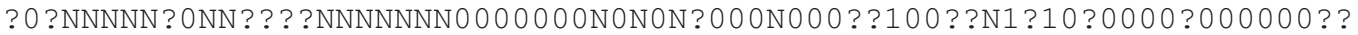
??? ?000??0000000100?00?0??0N01100?010?00000000??00N000003100??0?0001?

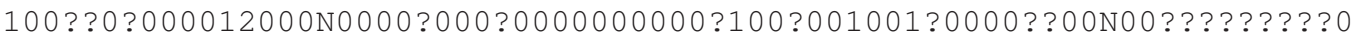
?00??00? 11000000 ??????????????????0N????0????????????????????? $0 \mathrm{~N} 0000$ NNONNNOONOO

\section{Steneosaurus bollensis}

1 [ 01$] 00000211002001110110011111$ ???10000 [01] 0N?000??01100000N11N010011 O ONNO O O O O ON [ 01 ] O ? ONO O O O ONO O O O 2 O I ONNO O O O O O O O ONNNO ONO ? O ONNNNNONO O O O ON 


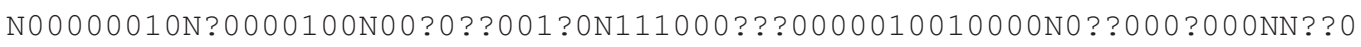
01101000 N? 0 [01] 00000011 ?000000000N01?11000N000N0 [01] 0110010??10000?00 ? 010 ? 001101010 NN0 00000001110001001111 ??10??01101001000001000?1000N210 $000000000100 ? 0 ? 0000$ N? 0002000000 N0000200000001000000000[01] 010?01?00?0

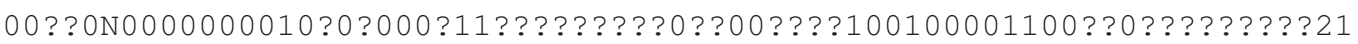
1 [01] [01] 00000?1000??010N000??00000

\section{Stolokrosuchus lapparenti}

111100020000210101101 ???110110111011001000010311000001110010000000000 0 0 0 0N1000N0001010000100101001010201????01100010N011100000010010000110 N00101100N11000N01010N110001011201011110000100100101100NN011001010001 1000011001120000000 ? 0N0?111 [01] ???????00?????1??110??00?1??1110001000 1000000000110100001301100 ??1011111??0000??0011010?00??1100000001???? 0 ?1? $100 \mathrm{~N}$ ??????02000N01001000110 [12] 000001002 ?????????????????????? ???????????????????????????????????????????????????????? ??????????? 00000110000001000

\section{Stratiotosuchus maxhechti}

101000011001 NN0211101??2?10110211000000?1001121100010100N0N1NN0211000 1001111110101 ???0000?30100N110000011101011000111010111000111000001011 000101101101011101 ? 20N11000N10N2110111000110N00N011011111011000010010 1101100101130010 ???010??11?????????1???????0210????0?1 ??10??0????11?? 0100100 ?? 01000110 ?1?00??0011???????11???????????11011??0????????????

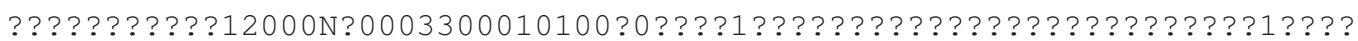
???????0?010111??11??10111???????????01??01101?1???????????????00011? ?00???010??

\section{Sunosuchus}

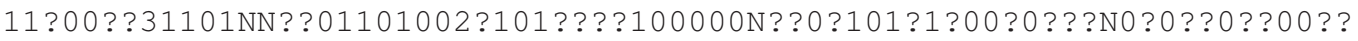
?0?1010 [01] 0N010????00010?101100??020?????011???10N011 ?N000??????0???

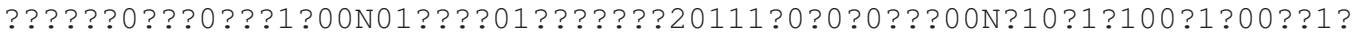

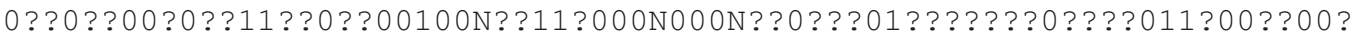
1?10000??1?1?1000?1?01??0?1??11111130?????????00????0N?1????0?????10? 


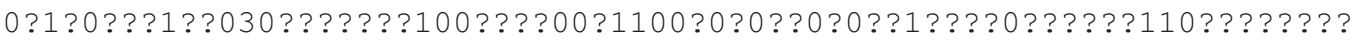
?0?0??????????????1????1?????1 ?0??? 110 ?? ?0???????? $2110 \mathrm{~N} 0$ ? 000 ? 1 ? ? 0 ? 01???0?0?0?0??

\section{Susisuchus anatoceps}

111000031101 NN010?????????? 1011100000 NN0 000 N21100100110N0?1N10100000 0000 N1 000 N000???0100?00101100010200????01100?10N0?110?00000NN0000?010 N00101100N01000N0?011101000N0???01?01?00?????00N010???????10??????? 0 ???????????????????????????????????????????????????????? ???????????? ???????? 01000010 ???????????1 ??? ?0??????????????????????????????????

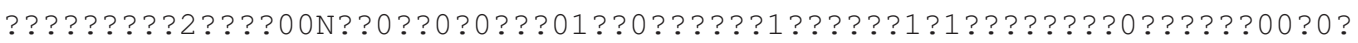
00 ??????????????????1??????????????0???????????30N1101102111000?01? ?00?????0??

\section{Terminonaris robusta}

111000021101 NN0101? 1100 [12] 1101?????01001N? 0000 N11100000?10N0? 0010000 00000 ?0N1010N000???110110 [01] 101100010200 ????0110??10N0100N000100NN10

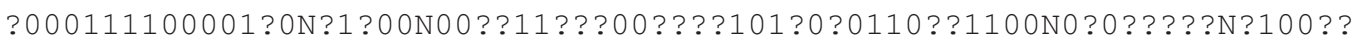
111 ???0?00000??111000000000N0?1?1[01] 00N0111??00N00000?10010?0?0?11?0

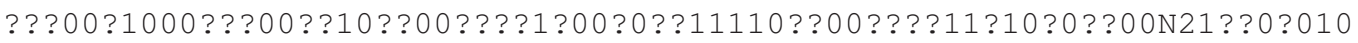
?0010?10?00????0002000000N010010100110[01] 0?00?00?01010001?00??????0N 00 ?????0??? ?000?? 11 ????????????0??????1????? 1110 ??0???????? 111110 ?? 00 ?1??00000??0000001???

\section{Theriosuchus}

$111001111000200101101001110 ? 1011100000010001031100000110 N 010110$ [ 12$] 10$ $0000000 \mathrm{~N} 1010 \mathrm{~N} 0001000100130101101000200100001100010 \mathrm{~N} 110$ ? ? 000000 NN1 0010 010N0 0? ? 0 0 0 0N00?00N000?11010001?10201101010000??00N?10??0100?10?1?01? 0????000000?110100000000N01111000N00 0N0000N0010000001000?0010??001000 10 ??????0??10??0??1??1????1?0101[01] ?0?0?10?00?10200?? [01] ??11???3010 0 ? 000 ? [ [01] 0??? $1110 ? 03$ ? 02000 N00001000?001100001002010?0????01??????1?

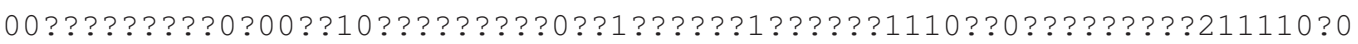
$00 ? 01 ? 000010 \mathrm{~N} 10000 ? ? ? 00$ 


\section{Trematochampsa taqueti}

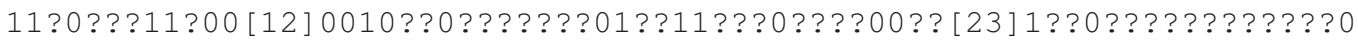
? 00000 ?000N1??0N?00????000?0?101[01]0?010?????????????10N01110?0??011 1???1???0N0????1????1??00??0?110100 [01] ??1?2110???1?0????00N0?0???100

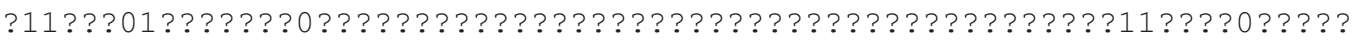
1?0?0?0001????00000???10001?3?11?????010?????0??0?1???0??0??00N01?0?1 010 ???????1???????????? 11000 N0100?0???1? [12] ?000?000 [12] ?1????????0?? ????110??????????????????????????????????????????????1??????????? [ 2 3 ] 0N? ?0?????1?????0?1100?00?100?

\section{Uberabasuchus terrificus}

11100001001020010110 ?????10??0???10000100001131100000100N011N00100000 0? 0 0N1 0 0 0N000???0000?0010100001010111010110001100110N00?001111000?110 N00?0?100N0100??0? [01]10N0100010?1211011010000??00N010?1?10??1????01?

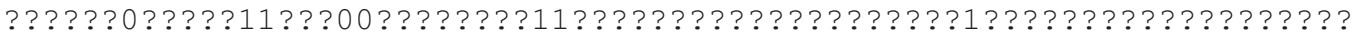
????????????0??0?????????????111111300???1?100?1??011111??0?0 [01] 0100 1101 ?? $1000 \mathrm{~N} 1$ ??00112000N0000100?110110?00100111????????0???????000??11 1 ?????????? 1 ?????????????1 ?????????????????????????????????? 00 [1 12 ? ???0???011?0???????0

Uruguaysuchus aznarezi

11100001011010 ??01101 [01] 1 [12]1?0?101???0?0?N?0000N3110??001??N01?? [0 1 ] ???????0?00N1?0??000????00???010??0??101001?10?????0110??????000?0N N100?1?100001???0??01?00N0?110N0??0?1????1??????????0N00N1?0?1?100?11

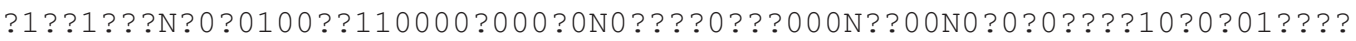
????0???????????????000????1??0???? 1101110001000 ????000?010N1111 ?00?0 ??0?0?011?0??????0?0 [01]10010?00020???0?1000?0100100??????????10???? 00 ????1???00?????1?????????0???0??????1???????111 ??1????????? $0 \mathrm{~N} 110$ ?? ???????0?????0?000???00

\section{Wargosuchus australis}

10 ??????0????????????????????????? 00 ?? 10011 ?? ??? 1 ???? ? 1 ?? ? 1 ?? 1000 10010 ??1 ????????0????????????????????????????????????????110???? 0 ?? 


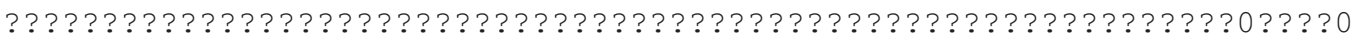

????????????????????????????????????????????????????????????????????

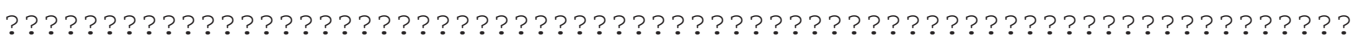

???????????1??? $0 \mathrm{~N}$ ??????00?1 ?????????0???????????????????????????????

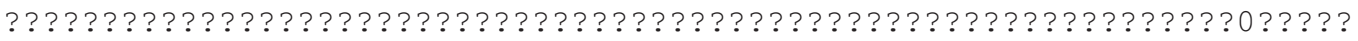

???????????

\section{Yacarerani boliviensis}

101000110111 NN010110101210011011100100?1?000N31101000100N0?0010200000 0000 N10 0 0N100???0000?20100N110101001???0110?011000011000010NN00001000 N11100001110?00N01010N11000?10N211?111?00?0??N0N1?001011000?1??01?0?N ?00011010110000010010N111110???100N1000N110 [02] 0??01100001010?000100? 10 ?????1?0??0?0001?0?1?00??001001100101?001101101?000N111?00001??0010 00 ? $0000 \mathrm{~N} 10101022210 \mathrm{~N} 00002201$ ? 001000 [01]111110??????????????????????? ???????????????????????????????????????????????????????????????? ??? $00011 ? ? 1000001 ? 00$

\section{Zosuchus davidisoni}

1110001101001001001110010 ??1??????0??00?0?0112110N000110N0100 [01] 0 ? 00 0 0 ?? 0 0N10?0N??0???00?0? [01] 0100N0101010011?0???00111001[01]1?100000N N?1000010N?00??000N000?0N??120N010001?0N001???? [01] ?111??00N010??0110

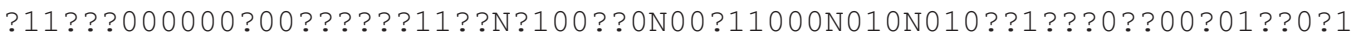
00001110010 ?????1 [01] ???010001??01?10??0????110?001??0001?000???0N100 00000 ? 000 ?? 000 ??010N?????000000N00003300?1?1?0?1000?11????????????? ??????????????????????????????????????????????????????????????????? ??????????00010N0000?0100? 


\section{APÊNDICE IV. LISTA DE SINAPOMORFIAS}

A lista de sinapomorfias obtidas para os clados recuperados no consenso estrito são apresentadas junto com seus respectivos números (Figura 7). Clados com Bootstrap (GC e frequências absolutas) e Jacknife GC são apontados quando maiores que 50\%, bem como o suporte de Bremmer quando maiores que 1. A anotação tomada para os índices é Bootstrap GC/Bootstrap absoluto/Jacknife/Bremer.

Clado123 (-/-/-/-):

Todas as árvores:

Caráter- 93: 1 -->0

Caráter- 94: 0 --> 1

Caráter- 142: 0 --> 1

Caráter- 145: 0 --> 1

Clado124 (-/-/-/-):

Sem sinapomorfias

Clado125 (-/-/-/-):

Todas as árvores:

Caráter- 14: 0 --> 2

Caráter- 18: 1 -->0

Caráter- 181: 0 -->1

Caráter- 245: 0 --> 1
Caráter- 307: 1 -->0

Caráter- 309: 0 --> 4

Caráter- 317: 0 --> 1

Caráter- 341: 0 --> 1

Caráter- 384: 0 --> 1

Caráter- 401: 0 --> 1

Caráter- 488: 0 --> 2

Clado126 (71/72/90/4):

Todas as árvores:

Caráter- 5: 0 --> 1

Caráter- 36: 0 --> 1

Caráter- 47: 1 -->0

Caráter- 60: 0 --> 1

Caráter- 64: 0 --> 1 
Caráter- 80: 0 --> 1

Caráter- 140: 0 --> 1

Caráter- 150: 0 --> 1

Caráter- 158: 1 -->0

Caráter- 165: 0 --> 1

Caráter- 268: 0 --> 1

Caráter- 271: 0 --> 1

Caráter- 298: 0 --> 1

Caráter- 383: 1 -->0

Caráter- 404: 0 --> 1

Clado127- (64/64/86/4) :

Todas as árvores:

Caráter- 1: 0 --> 1

Caráter- 3: 0 --> 1

Caráter- 13: 0 --> 1

Caráter- 90: 0 --> 1

Caráter- 110: 0 --> 1

Caráter- 125: 1 -->0

Caráter- 131: 1 -->0

Caráter- 303: 0 --> 1

Caráter- 305: 0 --> 1
Caráter- 420: 0 --> 1

Caráter- 482: 0 --> 1

Clado128 (-/-/-/2):

Todas as árvores:

Caráter- 18: 1 -->0

Caráter- 152: 0 --> 1

Caráter- 158: 1 --> 2

Caráter- 174: 0 --> 1

Caráter- 271: 0 --> 1

Caráter- 358: 2 --> 0

Caráter- 382: 0 --> 1

Clado129 (-/-/-/-):

Todas as árvores:

Caráter- 64: 0 --> 2

Caráter- 98: 0 --> 1

Caráter- 357: 1 --> 0

Caráter- 378: 0 --> 1

Caráter- 384: 0 --> 1

Clado130 (-/-/-/2):

Todas as árvores:

Caráter- 32: 0 --> 1 
Caráter- 137: 0 --> 1

Caráter- 172: 0 --> 1

Caráter- 177: 0 --> 1

Caráter- 217: 0 --> 1

Caráter- 232: 0 --> 1

Caráter- 257: 0 --> 1

Caráter- 287: 0 --> 1

Caráter- 292: 0 --> 1

Caráter- 374: 0 --> 1

Caráter- 387: 0 --> 1

Algumas árvores:

Caráter- 261: 1 -->0

Clado131 (53/58/73/2) :

Todas as árvores:

Caráter- 218: 1 -->0

Caráter- 311: 0 --> 1

Caráter- 378: 1 -->0

Clado132 (-/-/-/-):

Todas as árvores:

Caráter- 19: 0 --> 1

Caráter- 198: 0 --> 1
Caráter- 281: 0 --> 1

Caráter- 291: 0 --> 1

Clado133 (-/-/-/-):

Todas as árvores:

Caráter- 7: 1 -->0

Caráter- 45: 1 -->0

Caráter- 145: 0 --> 1

Caráter- 259: 1 -->0

Caráter- 340: 0 --> 1

Caráter- 355: 0 --> 3

Clado134 (-/-/-/-):

Todas as árvores:

Caráter- 154: 1 -->0

Clado135 (-/-/64/2):

Todas as árvores:

Caráter- 149: 0 --> 1

Caráter- 283: 0 --> 1

Clado136 (-/-/55/3) :

Todas as árvores:

Caráter- 74: 0 --> 1

Caráter- 76: 0 --> 1 
Caráter- 80: 0 --> 1

Caráter- 102: 1 --> 0

Caráter- 195: 0 --> 1

Caráter- 252: 0 --> 2

Clado137 (-/-/54/3) :

Todas as árvores:

Caráter- 52: 0 --> 1

Caráter- 212: 0 --> 1

Caráter- 313: 0 --> 1

Clado138 (-/-/-/-):

Todas as árvores:

Caráter- 384: 0 --> 1

Algumas árvores:

Caráter- 129: 0 --> 1

Caráter- 199: 0 --> 1

Caráter- 211: 0 --> 1

Caráter- 372: 0 --> 1

Clado139 (-/-/-/-):

Todas as árvores:

Caráter- 319: 1 -->0

Caráter- 357: 2 --> 1
Caráter- 366: 1 -->0

Caráter- 385: 0 --> 1

Algumas árvores:

Caráter- 8: 1 -->0

Caráter- 10: 1 -->0

Caráter- 45: 0 --> 1

Caráter- 374: 0 --> 1

Clado140 (-/-/-/-):

Todas as árvores:

Caráter- 142: 0 --> 1

Caráter- 320: 1 --> 0

Caráter- 335: 0 --> 1

Clado141 (-/-/-/-):

Todas as árvores:

Caráter- 44: 0 --> 1

Caráter- 46: 3 --> 2

Caráter- 336: 1 --> 0

Clado142 (-/-/-/-):

Todas as árvores:

Caráter- 13: 1 --> 2

Caráter- 24: 1 --> 2 
Caráter- 97: 0 --> 1

Caráter- 200: 1 --> 0

Caráter- 236: 0 --> 1

Caráter- 243: 0 --> 1

Caráter- 276: 0 --> 1

Caráter- 278: 0 --> 1

Caráter- 285: 1 --> 0

Caráter- 293: 3 --> 0

Caráter- 337: 0 --> 1

Caráter- 346: 1 --> 0

Clado143 (-/-/-/-):

Todas as árvores:

Caráter- 156: 0 --> 1

Caráter- 194: 0 --> 1

Caráter- 304: 1 --> 0

Caráter- 310: 0 --> 1

Clado144 (-/-/-/-):

Todas as árvores:

Caráter- 70: 0 --> 1

Caráter- 230: 0 --> 1

Caráter- 256: 0 --> 1
Caráter- 336: 0 --> 1

Caráter- 361: 1 --> 0

Caráter- 366: 0 --> 1

Caráter- 378: 1 -->0

Clado145 (-/-/-/-):

Todas as árvores:

Caráter- 12: 0 --> 1

Caráter- 107: 0 --> 1

Caráter- 167: 0 --> 1

Caráter- 320: 0 --> 1

Clado146 (-/-/-/-):

Todas as árvores:

Caráter- 2: 1 -->0

Caráter- 24: 2 --> 1

Caráter- 168: 1 -->0

Caráter- 340: 1 --> 0

Caráter- 352: 0 --> 2

Caráter- 402: 1 -->0

Algumas árvores:

Caráter- 60: 1 -->0

Clado147 (-/-/-/-): 
Todas as árvores:

Caráter- 7: 0 --> 1

Caráter- 131: 1 -->0

Caráter- 140: 0 --> 1

Caráter- 248: 0 --> 1

Caráter- 344: 1 --> 0

Algumas árvores:

Caráter- 341: 0 --> 1

Clado148 (-/-/-/-):

Todas as árvores:

Caráter- 44: 1 -->0

Caráter- 250: 1 -->0

Caráter- 361: 0 --> 1

Caráter- 375: 1 -->0

Algumas árvores:

Caráter- 221: 1 -->0

Clado149 (-/-/-/-):

Todas as árvores:

Caráter- 36: 0 --> 1

Caráter- 187: 0 --> 1

Caráter- 305: 1 --> 0
Caráter- 319: 0 --> 1

Caráter- 358: 2 --> 1

Caráter- 378: 0 --> 1

Algumas árvores:

Caráter- 11: 0 --> 1

Caráter- 26: 1 -->0

Caráter- 95: 1 --> 0

Caráter- 102: 2 --> 1

Caráter- 325: 0 --> 1

Clado150 (-/-/-/-):

Todas as árvores:

Caráter- 100: 0 --> 1

Caráter- 171: 0 --> 1

Caráter- 174: 0 --> 1

Caráter- 208: 0 --> 1

Caráter- 263: 0 --> 1

Caráter- 273: 0 --> 1

Caráter- 291: 0 --> 1

Caráter- 344: 0 --> 1

Caráter- 355: 3 --> 1

Caráter- 393: 0 --> 1 
Caráter- 396: 0 --> 1

Caráter- 398: 0 --> 1

Caráter- 405: 0 --> 1

Caráter- 409: 0 --> 1

Caráter- 412: 0 --> 1

Caráter- 415: 0 --> 1

Caráter- 417: 0 --> 1

Caráter- 429: 0 --> 1

Caráter- 446: 0 --> 1

Caráter- 462: 0 --> 1

Caráter- 466: 1 -->0

Algumas árvores:

Caráter- 60: 0 --> 1

Caráter- 62: 1 --> 0

Caráter- 85: 0 --> 1

Caráter- 121: 0 --> 1

Caráter- 134: 0 --> 1

Caráter- 144: 0 --> 1

Caráter- 198: 0 --> 1

Caráter- 221: 0 --> 1

Caráter- 293: 0 --> 3
Caráter- 317: 0 --> 1

Caráter- 330: 0 --> 1

Caráter- 408: 0 --> 1

Caráter- 451: 0 --> 1

Clado151 (-/-/-/3):

Todas as árvores:

Caráter- 20: 1 --> 0

Caráter- 64: 0 --> 1

Caráter- 83: 0 --> 1

Caráter- 131: 0 --> 1

Caráter- 134: 0 --> 1

Caráter- 170: 0 --> 2

Caráter- 191: 0 --> 1

Caráter- 250: 0 --> 1

Caráter- 346: 0 --> 1

Caráter- 351: 0 --> 1

Caráter- 380: 0 --> 1

Caráter- 401: 0 --> 1

Caráter- 489: 1 -->0

Caráter- 491: 0 --> 1

Clado152 (-/-/-/3): 
Todas as árvores:

Caráter- 13: 1 --> 2

Caráter- 26: 0 --> 1

Caráter- 203: 0 --> 1

Caráter- 223: 1 -->0

Caráter- 231: 0 --> 1

Caráter- 244: 1 --> 0

Caráter- 319: 1 --> 0

Caráter- 421: 0 --> 1

Algumas árvores:

Caráter- 240: 1 -->0

Clado153 (50/51/75/1) :

Todas as árvores:

Caráter- 63: 0 --> 1

Clado154 (-/-/77/2):

Todas as árvores:

Caráter- 184: 0 --> 1

Caráter- 240: 0 --> 1

Clado155 (-/-/-/-):

Todas as árvores:

Caráter- 2: 1 -->0
Caráter- 126: 0 --> 1

Clado156 (-/-/-/-):

Todas as árvores:

Caráter- 35: 0 --> 1

Caráter- 128: 0 --> 1

Caráter- 199: 0 --> 1

Clado157 (-/-/-/-):

Todas as árvores:

Caráter- 8: 3 -->0

Caráter- 11: 0 --> 1

Caráter- 23: 0 --> 1

Caráter- 26: 1 -->0

Algumas árvores:

Caráter- 9: 1 -->0

Caráter- 137: 1 -->0

Caráter- 159: 0 --> 1

Caráter- 213: 0 --> 1

Clado158 (-/-/-/-):

Todas as árvores:

Caráter- 53: 0 --> 1

Caráter- 134: 1 --> 0 
Caráter- 138: 0 --> 1

Caráter- 246: 0 --> 1

Caráter- 313: 0 --> 1

Caráter- 375: 1 -->0

Algumas árvores:

Caráter- 12: 0 --> 1

Caráter- 56: 0 --> 1

Caráter- 60: 1 -->0

Caráter- 85: 1 -->0

Caráter- 96: 0 --> 1

Caráter- 383: 1 --> 01

Clado159 (71/72/-/-):

Todas as árvores:

Caráter- 8: 1 --> 3

Caráter- 37: 0 --> 1

Caráter- 91: 0 --> 1

Caráter- 265: 0 --> 1

Caráter- 382: 0 --> 1

Algumas árvores:

Caráter- 79: 12 -->0

Caráter- 97: 0 --> 1
Caráter- 142: 0 --> 1

Caráter- 149: 0 --> 1

Caráter- 221: 01 --> 1

Caráter- 242: 0 --> 1

Caráter- 330: 1 -->0

Caráter- 333: 0 --> 2

Caráter- 337: 0 --> 1

Caráter- 384: 0 --> 1

Caráter- 397: 0 --> 1

Caráter- 438: 0 --> 1

Caráter- 452: 0 --> 1

Clado160 (-/-/-/2):

Todas as árvores:

Caráter- 380: 1 -->0

Caráter- 494: 0 --> 1

Clado161 (-/-/-/-):

Algumas árvores:

Caráter- 45: 0 --> 1

Caráter- 136: 0 --> 1

Caráter- 142: 0 --> 1

Caráter- 176: 0 --> 1 
Caráter- 190: 0 --> 1

Caráter- 200: 1 --> 0

Caráter- 284: 0 --> 1

Caráter- 333: 0 --> 1

Caráter- 337: 0 --> 1

Caráter- 371: 0 --> 1

Caráter- 372: 0 --> 1

Caráter- 374: 1 --> 2

Caráter- 384: 0 --> 1

Caráter- 385: 0 --> 1

Caráter- 484: 0 --> 1

Clado162 (-/-/-/-):

Todas as árvores:

Caráter- 127: 0 --> 1

Algumas árvores:

Caráter- 201: 1 -->0

Clado163 (-/-/-/-):

Todas as árvores:

Caráter- 214: 0 --> 1

Caráter- 265: 0 --> 1

Algumas árvores:
Caráter- 60: 1 -->0

Caráter- 102: 1 --> 2

Caráter- 116: 1 -->0

Caráter- 182: 0 --> 1

Caráter- 219: 0 --> 2

Caráter- 364: 0 --> 1

Clado164 (-/-/85/3):

Todas as árvores:

Caráter- 161: 0 --> 1

Caráter- 193: 1 -->0

Caráter- 333: 1 -->0

Caráter- 357: 1 --> 0

Algumas árvores:

Caráter- 4: 0 --> 1

Caráter- 8: 1 --> 2

Caráter- 14: 0 --> 1

Caráter- 35: 0 --> 1

Caráter- 36: 0 --> 1

Caráter- 45: 1 -->0

Caráter- 129: 1 -->0

Caráter- 130: 1 -->0 
Caráter- 160: 1 -->0

Caráter- 185: 0 --> 1

Caráter- 266: 0 --> 1

Caráter- 318: 0 --> 1

Caráter- 383: 1 --> 2

Clado165 (-/-/-/-):

Todas as árvores:

Caráter- 174: 1 -->0

Caráter- 364: 1 -->0

Clado166 (-/-/-/-):

Todas as árvores:

Caráter- 328: 1 -->0

Caráter- 335: 0 --> 1

Algumas árvores:

Caráter- 304: 1 -->0

Caráter- 380: 1 -->0

Clado167 (-/-/-/-):

Todas as árvores:

Caráter- 12: 1 -->0

Caráter- 206: 0 --> 3

Caráter- 251: 0 --> 2
Clado168 (-/-/-/-):

Todas as árvores:

Caráter- 46: 3 --> 1

Caráter- 101: 0 --> 1

Caráter- 121: 1 -->0

Caráter- 259: 0 --> 1

Caráter- 365: 0 --> 1

Caráter- 376: 0 --> 1

Clado169 (-/-/-/-):

Todas as árvores:

Caráter- 70: 1 -->0

Caráter- 141: 0 -->1

Caráter- 144: 1 --> 0

Caráter- 149: 0 --> 1

Caráter- 359: 0 --> 2

Caráter- 360: 0 --> 1

Caráter- 382: 0 --> 1

Clado170 (-/-/-/-):

Todas as árvores:

Caráter- 364: 0 --> 1

Clado171 (-/-/-/-): 
Todas as árvores:

Caráter- 358: 1 --> 2

Clado172 (71/71/94/3) :

Todas as árvores:

Caráter- 333: 1 -->0

Caráter- 358: 1 --> 2

Caráter- 366: 1 -->0

Clado173 (-/-/-/-):

Todas as árvores:

Caráter- 322: 0 --> 1

Clado174 (-/-/-/-):

Todas as árvores:

Caráter- 22: 0 --> 2

Algumas árvores:

Caráter- 54: 1 --> 0

Caráter- 107: 0 --> 1

Caráter- 120: 1 --> 0

Caráter- 177: 1 -->0

Caráter- 251: 0 --> 1

Caráter- 252: 0 --> 1

Caráter- 257: 1 --> 0
Caráter- 301: 1 -->0

Caráter- 331: 0 --> 1

Caráter- 340: 1 -->0

Caráter- 476: 1 -->0

Clado175 (-/-/-/-):

Todas as árvores:

Caráter- 6: 0 --> 1

Caráter- 45: 0 --> 2

Caráter- 152: 0 --> 1

Caráter- 158: 1 --> 2

Caráter- 173: 0 --> 1

Caráter- 199: 0 --> 1

Caráter- 281: 0 --> 1

Caráter- 297: 0 --> 1

Caráter- 435: 1 -->0

Algumas árvores:

Caráter- 119: 1 -->0

Caráter- 132: 0 --> 1

Caráter- 159: 0 --> 1

Caráter- 320: 0 --> 1

Clado176 (-/-/51/-) : 
Algumas árvores:

Caráter- 128: 1 --> 0

Caráter- 132: 1 -->0

Caráter- 150: 1 -->0

Caráter- 221: 1 -->0

Caráter- 250: 1 --> 0

Caráter- 251: 1 -->0

Caráter- 252: 1 --> 0

Clado177 (-/-/-/-):

Todas as árvores:

Caráter- 41: 0 --> 1

Caráter- 118: 0 --> 1

Caráter- 213: 0 --> 1

Caráter- 223: 0 --> 1

Caráter- 359: 0 --> 1

Caráter- 372: 0 --> 1

Caráter- 379: 0 --> 1

Caráter- 399: 0 --> 1

Clado178 (77/78/98/6) :

Todas as árvores:

Caráter- 51: 0 --> 1
Caráter- 78: 1 -->0

Caráter- 142: 0 --> 1

Caráter- 240: 0 --> 1

Caráter- 322: 0 --> 1

Caráter- 364: 0 --> 1

Caráter- 365: 0 --> 1

Caráter- 366: 1 -->0

Caráter- 370: 0 --> 1

Clado179 (-/-/-/-):

Todas as árvores:

Caráter- 8: 1 --> 3

Caráter- 33: 1 --> 0

Caráter- 36: 1 --> 0

Caráter- 118: 0 --> 1

Caráter- 158: 1 --> 2

Caráter- 198: 1 -->0

Caráter- 241: 0 --> 1

Caráter- 281: 0 --> 1

Caráter- 335: 0 --> 2

Caráter- 349: 0 --> 1

Caráter- 369: 0 --> 2 
Clado180 (-/-/-/-):

Todas as árvores:

Caráter- 55: 1 -->0

Caráter- 152: 0 --> 1

Caráter- 180: 0 --> 1

Caráter- 328: 1 -->0

Caráter- 346: 1 -->0

Caráter- 367: 2 -->0

Clado181 (-/-/-/-):

Todas as árvores:

Caráter- 120: 1 -->0

Caráter- 372: 0 --> 1

Clado182 (70/70/72/3) :

Todas as árvores:

Caráter- 16: 1 -->0

Caráter- 28: 1 -->0

Caráter- 103: 0 --> 1

Caráter- 119: 1 -->0

Caráter- 123: 0 --> 1

Caráter- 190: 0 --> 2

Caráter- 193: 1 -->0
Caráter- 288: 0 --> 1

Caráter- 480: 0 --> 1

Caráter- 486: 0 --> 1

Caráter- 490: 0 --> 1

Caráter- 492: 0 --> 1

Clado183 (-/-/-/-):

Todas as árvores:

Caráter- 266: 0 --> 1

Caráter- 333: 0 --> 3

Caráter- 335: 0 --> 1

Clado184 (71/72/79/3):

Todas as árvores:

Caráter- 14: 0 --> 1

Caráter- 16: 1 --> 2

Caráter- 38: 0 --> 1

Caráter- 52: 0 --> 1

Caráter- 82: 0 --> 1

Caráter- 116: 1 --> 2

Caráter- 131: 1 -->0

Caráter- 152: 0 --> 1

Caráter- 155: 0 --> 1 
Caráter- 161: 0 --> 1

Caráter- 164: 0 --> 1

Caráter- 168: 1 -->0

Caráter- 235: 0 --> 1

Caráter- 250: 1 -->0

Caráter- 251: 0 --> 1

Caráter- 328: 1 -->0

Caráter- 335: 0 --> 1

Caráter- 342: 0 --> 1

Caráter- 343: 0 --> 1

Caráter- 380: 1 -->0

Algumas árvores:

Caráter- 60: 01 --> 1

Caráter- 198: 1 -->0

Caráter- 240: 0 --> 1

Caráter- 241: 0 --> 1

Caráter- 315: 0 --> 1

Clado185 (84/84/95/4) :

Todas as árvores:

Caráter- 8: 1 -->2

Caráter- 10: 0 --> 1
Caráter- 17: 0 --> 1

Caráter- 33: 1 --> 0

Caráter- 46: 3 -->0

Caráter- 56: 0 --> 1

Caráter- 90: 1 --> 2

Caráter- 92: 0 --> 1

Caráter- 93: 1 -->0

Caráter- 105: 1 -->0

Caráter- 110: 1 -->0

Caráter- 161: 0 --> 1

Caráter- 163: 0 --> 1

Caráter- 172: 1 --> 0

Caráter- 177: 1 --> 0

Caráter- 188: 1 -->0

Caráter- 193: 1 -->0

Caráter- 210: 0 --> 1

Caráter- 246: 0 --> 1

Caráter- 285: 1 --> 0

Caráter- 286: 0 --> 1

Caráter- 298: 0 --> 1

Caráter- 305: 1 --> 0 
Caráter- 328: 1 --> 2

Caráter- 355: 3 --> 2

Caráter- 357: 1 -->0

Caráter- 358: 2 --> 0

Caráter- 374: 1 -->0

Caráter- 383: 1 -->0

Caráter- 411: 0 --> 1

Caráter- 434: 1 --> 0

Caráter- 443: 0 --> 1

Caráter- 476: 1 --> 0

Algumas árvores:

Caráter- 272: 0 --> 1

Clado186 (-/-/-/-):

Todas as árvores:

Caráter- 3: 1 -->0

Caráter- 166: 1 -->0

Caráter- 178: 0 --> 1

Clado187 (76/76/95/4) :

Todas as árvores:

Caráter- 1: 1 -->0

Caráter- 11: 0 --> 1
Caráter- 14: 0 --> 1

Caráter- 59: 1 -->0

Caráter- 68: 0 --> 1

Caráter- 70: 0 --> 1

Caráter- 94: 0 --> 1

Caráter- 112: 0 --> 1

Caráter- 306: 1 -->0

Caráter- 367: 2 --> 3

Caráter- 414: 0 --> 1

Caráter- 472: 0 --> 1

Algumas árvores:

Caráter- 101: 0 --> 1

Clado188 (-/-/-/-):

Todas as árvores:

Caráter- 293: 0 --> 2

Caráter- 482: 1 -->0

Clado189 (-/-/-/2):

Todas as árvores:

Caráter- 221: 0 --> 1

Caráter- 358: 0 --> 2

Caráter- 491: 0 --> 1 
Algumas árvores:

Caráter- 101: 1 --> 0

Clado190 (-/-/-/2):

Todas as árvores:

Caráter- 10: 1 -->0

Caráter- 24: 1 -->0

Caráter- 152: 0 --> 1

Algumas árvores:

Caráter- 64: 0 --> 2

Clado191 (-/-/-/-):

Todas as árvores:

Caráter- 482: 0 --> 1

Clado192 (68/69/95/3) :

Todas as árvores:

Caráter- 109: 0 --> 1

Caráter- 124: 0 --> 1

Algumas árvores:

Caráter- 125: 0 --> 1

Caráter- 142: 0 --> 1

Caráter- 293: 2 --> 1

Caráter- 324: 0 --> 1
Caráter- 478: 0 --> 1

Clado193 (65/69/88/3) :

Todas as árvores:

Caráter- 55: 1 --> 0

Caráter- 87: 1 -->0

Caráter- 94: 0 --> 1

Caráter- 256: 0 --> 1

Caráter- 277: 0 --> 1

Algumas árvores:

Caráter- 37: 0 --> 1

Clado194 (80/81/98/5) :

Todas as árvores:

Caráter- 17: 0 --> 1

Caráter- 288: 0 --> 1

Caráter- 290: 0 --> 1

Caráter- 356: 0 --> 1

Caráter- 377: 0 --> 1

Algumas árvores:

Caráter- 146: 01 --> 1

Caráter- 173: 1 -->0

Caráter- 177: 1 --> 0 
Caráter- 182: 1 -->0

Caráter- 215: 0 --> 1

Caráter- 243: 0 --> 1

Caráter- 272: 0 --> 1

Caráter- 293: 0 --> 3

Caráter- 335: 1 -->0

Caráter- 488: 0 --> 1

Clado195 (-/-/60/3) :

Algumas árvores:

Caráter- 8: 3 --> 2

Caráter- 20: 0 --> 1

Caráter- 35: 0 --> 1

Caráter- 44: 1 -->0

Caráter- 64: 1 -->0

Caráter- 85: 1 -->0

Caráter- 89: 0 --> 1

Caráter- 100: 0 --> 01

Caráter- 134: 1 -->0

Caráter- 138: 0 --> 1

Caráter- 156: 1 -->0

Caráter- 157: 0 --> 1
Caráter- 158: 1 -->0

Caráter-170: 2 --> 1

Caráter- 193: 1 -->0

Caráter- 204: 0 --> 1

Caráter- 219: 0 --> 1

Caráter- 250: 1 -->0

Caráter- 300: 1 --> 0

Caráter- 312: 0 --> 1

Caráter- 317: 0 --> 1

Caráter- 328: 0 --> 2

Caráter- 355: 3 --> 2

Caráter- 374: 1 --> 0

Caráter- 464: 2 --> 1

Clado196 (-/-/-/-):

Todas as árvores:

Caráter- 10: 0 --> 1

Caráter- 12: 0 --> 1

Caráter- 265: 0 --> 1

Caráter- 358: 2 -->0

Algumas árvores:

Caráter- 8: 1 --> 3 
Caráter- 46: 3 -->1

Caráter- 114: 0 --> 1

Caráter- 156: 0 --> 1

Caráter- 273: 0 --> 1

Caráter- 308: 0 --> 1

Caráter- 312: 1 -->0

Caráter- 364: 0 --> 1

Caráter- 374: 1 --> 12

Caráter- 380: 1 -->0

Clado197 (-/-/-/-):

Todas as árvores:

Caráter- 87: 0 --> 1

Caráter- 116: 1 -->0

Caráter- 357: 1 -->0

Clado198 (81/81/95/3) :

Todas as árvores:

Caráter- 77: 1 -->0

Caráter- 88: 0 --> 1

Clado199 (78/78/93/3) :

Todas as árvores:

Caráter- 103: 0 --> 1
Caráter- 482: 1 -->0

Algumas árvores:

Caráter- 42: 0 --> 1

Caráter- 71: 0 --> 1

Clado200 (62/63/92/4) :

Todas as árvores:

Caráter- 81: 0 --> 1

Caráter- 87: 1 --> 0

Caráter- 226: 0 --> 1

Algumas árvores:

Caráter- 32: 1 --> 0

Caráter- 43: 0 --> 1

Caráter- 49: 0 --> 1

Caráter- 86: 0 --> 1

Caráter- 319: 0 --> 1

Caráter- 337: 0 --> 1

Caráter- 467: 1 -->0

Clado201 (-/-/-/-):

Todas as árvores:

Caráter- 394: 0 --> 1

Algumas árvores: 
Caráter- 28: 1 -->0

Caráter- 46: 1 --> 2

Caráter- 60: 0 --> 1

Caráter- 77: 1 -->0

Caráter- 119: 1 -->0

Caráter- 121: 0 --> 1

Caráter- 144: 0 --> 1

Caráter- 196: 0 --> 1

Caráter- 304: 1 --> 0

Caráter- 383: 2 --> 0

Caráter- 393: 0 --> 1

Caráter- 403: 0 --> 1

Caráter- 413: 0 --> 1

Caráter- 466: 1 -->0

Caráter- 473: 0 --> 2

Clado202 (-/-/-/-):

Todas as árvores:

Caráter- 104: 0 --> 1

Algumas árvores:

Caráter- 87: 1 -->0

Caráter- 91: 0 --> 2
Caráter- 100: 1 -->0

Caráter- 119: 0 --> 1

Caráter- 140: 0 --> 1

Caráter- 182: 1 --> 0

Caráter- 190: 1 --> 2

Clado203 (62/64/85/3) :

Todas as árvores:

Caráter- 7: 0 --> 1

Caráter- 20: 0 --> 1

Caráter- 26: 1 -->0

Algumas árvores:

Caráter- 65: 0 --> 1

Clado204 (-/-/-/-):

Todas as árvores:

Caráter- 346: 1 -->0

Caráter- 349: 0 --> 1

Algumas árvores:

Caráter- 142: 1 -->0

Caráter- 364: 1 -->0

Clado205 (-/-/53/-) :

Todas as árvores: 
Caráter- 67: 0 --> 1

Caráter- 227: 0 --> 1

Algumas árvores:

Caráter- 6: 0 --> 1

Caráter- 60: 0 --> 1

Caráter- 134: 0 --> 1

Caráter- 220: 1 -->0

Caráter- 226: 0 --> 1

Caráter- 235: 2 --> 1

Caráter- 240: 2 --> 0

Caráter- 306: 1 -->0

Caráter- 374: 0 --> 1

Caráter- 468: 1 -->0

Clado206 (-/-/68/3) :

Todas as árvores:

Caráter- 37: 0 --> 1

Caráter- 120: 1 --> 0

Caráter- 431: 0 --> 1

Caráter- 469: 0 --> 1

Caráter- 475: 1 -->0

Algumas árvores:
Caráter- 30: 0 --> 1

Caráter- 77: 0 --> 1

Caráter- 84: 0 --> 1

Caráter- 123: 1 -->0

Caráter- 134: 0 --> 1

Caráter- 261: 0 --> 1

Caráter- 314: 0 --> 1

Caráter- 345: 0 --> 1

Clado207 (62/66/86/5):

Todas as árvores:

Caráter- 71: 0 --> 1

Caráter- 201: 0 --> 1

Caráter- 320: 0 --> 3

Caráter- 364: 1 --> 0

Caráter- 374: 0 --> 2

Caráter- 392: 1 --> 0

Caráter- 416: 0 --> 1

Algumas árvores:

Caráter- 6: 0 --> 1

Caráter- 329: 1 -->0

Caráter- 383: 0 --> 2 


\section{REFERÊNCIAS BIBLIOGRÁFICAS ADICIONAIS}

Bonaparte, J. F. 1971. Los vertebrados fósiles de la Formación Rio Colorado, de la Ciudad de Neuquén y cercanías, Cretácico Superior, Argentina. Revista del Museo Argentino de Ciências Naturales 4:17-123.

Brochu, C. A. 2010. A new alligatorid from the Lower Eocene Green River Formation of Wyoming and the origins of caimans. Journal of Vertebrate Paleontology 30:1109-1126.

Brochu, C. A., M. L. Bouaré, F. Sissoko, E. M. Roberts, and M. A. O'Leary. 2002. A dyrosaurid crocodyliform braincase from Mali. Journal of Paleontology 76:1060-1071.

Brochu, C. A., J. Njau, R. J. Blumenschine, \& L. Densmore. 2010. A New Horned Crocodile from the Plio-Pleistocene Hominid Sites at Olduvai Gorge, Tanzania. Plos ONE 5:e9333.

Brown, B. 1933. An ancestral crocodile. American Museum Novitates 638:1-4.

Buffetaut, E., \& R. Hoffstetter. 1977. Découvert du Crocodilien Sebecus dans le Miocène du Pérou oriental. Comptes Rendus de l'Académie Des Sciences 284:1663-1666.

Buffetaut, E., \& R. Ingavat. 1980. A new crocodilian from the Jurassic of Thailand, Sunosuchus thailandicus n. sp. (Mesosuchia, Goniopholididae), and the Paleogeographical history of South-east Asia in the Mesozoic. Géobios 13:879-889.

Buffetaut, E., \& L. G. Marshall. 1991. A new crocodilian, Sebecus querejazus, nov. sp. (Mesosuchia, Sebecidae) from the Santa Lucia Formation (Early Paleocene) at Vila Vila, Southern Bolivia; pp. 545-557 in R. Suarez-Soruco (ed.), Fosiles y Facies de Bolivia. Revista Técnica de YPFB, Santa Cruz.

Buffetaut, E. 1979. Revision der Crocodylia (Reptilia) aus der Gosau-Schichten (Ober-Kreide) von Österreich. Beiträge zur Paläontologie von Österreich 6:89-105.

Bunzel, E. 1871. Die Reptilfauna der Gosau-Formation in der Neuen Welt bei Wiener-Neustadt. Abhandlungen Geologische Reichsanstalt 5:1-18.

Busbey III, A. B., \& C. E. Gow. 1984. A new protosuchian crocodile from the Upper Elliot Formation of South Africa. Palaeontologia Africana 25:127-149.

Busbey III, A. B. 1986. New materials of Sebecus cf. huilensis (Crocodylia: Sebecosuchidae) from the Miocene La Venta Formation of Colombia. Journal of Vertebrate Paleontology 6:20-27. 
Campos, D. A., J. M. Suarez, D. Riff, \& A. W. A. Kellner. 2001. Short note on a new Baurusuchidae (Crocodyliformes, Metasuchia) from the Upper Cretaceous of Brazil. Boletim do Museu Nacional 57:1-8.

Campos, D. A., G. R. Oliveira, R. G. Figueiredo, D. Riff, S. A. Azevedo, L. B. Carvalho, \& A. W. A. Kellner. 2011. On a new peirosaurid crocodyliform from the Upper Cretaceous, Bauru Group, southeastern Brazil. Anais da Academia Brasileira de Ciências 83:317-327.

Carvalho, I. S., \& R. J. Bertini. 1999. Mariliasuchus, um novo Crocodylomorpha (Notosuchia) do Cretáceo da Bacia Bauru, Brasil. Geologia Colombiana 24:83-105.

Carvalho, I. S., \& D. A. Campos. 1988. Um mamífero triconodonte do Cretáceo Inferior do Maranhão, Brasil. Anais da Academia Brasileira de Ciências 60:437-446.

Carvalho, I. S. 1994. Candidodon: um crocodilo com heterodontia (Notosuchia, Cretáceo Inferior). Anais da Academia Brasileira de Ciências 66:331-346.

Carvalho, I. S., F. M. Vasconcellos, \& S. A. S. Tavares. 2007. Montealtosuchus arrudacamposi, a new peirosaurid crocodile (Mesoeucrocodylia) from the Late Cretaceous Adamantina Formation of Brazil. Zootaxa 1607:35-46.

Carvalho, I. S., V. P. A. Teixeira, M. L. F. Ferraz, L. C. B. Ribeiro, A. G. Martinelli, F. M. Neto, J. J. W. Sertich, G. C. Cunha, I. C. Cunha, \& P. F. Ferraz. 2011. Campinasuchus dinizi gen. et sp. nov., a new Late Cretaceous baurusuchid (Crocodyliformes) from the Bauru Basin, Brazil. Zootaxa 2871:19-42.

Clark, J. M., L. L. Jacobs, \& W. R. Downs. 1989. Mammal-like dentition in a Mesozoic crocodylian. Science 244:1064-1066.

Delfino, M., V. Codrea, A. Folie, P. Dica, P. Godefroit, \& T. Smith. 2008. A complete skull of Allodaposuchus precedens Nopsca, 1928 (Eusuchia) and a reassessment of the morphology of the taxon based on the Romanian remains. Journal of Vertebrate Paleontology 28:111122.

Denton, R. K., J. L. Dobie, \& D. C. Parris. 1997. The marine crocodilian Hyposaurus in North America; pp. in J. M. Callaway and E. L. Nicholls (eds.), Ancient Marine Reptiles. Academic Press, San Diego.

Fernandez, M., A. P. Carabajal, Z. Gasparini, \& G. C. Díaz. 2011. A metriorhynchid crocodyliform braincase from northern Chile. Journal of Vertebrate Paleontology 31:369-377. 
Figueiredo, R. G., \& A. W. A. Kellner. 2009. A new crocodylomorph specimen from the Araripe Basin (Crato Member, Santana Formation), northeastern Brazil. Paläontologische Zeitschrift 83:323-331.

Frey, E. 1988. Das Tragsystem der Krocodile - eine biomechanische und phylogenetische Analyse. Stuttgarter Beitrage zur Naturkunde (serie A) 426:1-60.

Frey, E., M.-C. Buchy, W. Stinnesbeck, \& J. G. López-Oliva. 2002. Geosaurus vignaudi n.sp. (Crocodyliformes:Thalattosuchia), first evidence of metriorhynchid crocodilians in the Late Jurassic (Tithonian) of central-east Mexico (State of Puebla). Canadian Journal of Earth Sciences 39:1467-1483.

Gao, Y.-H. 2001. A new species of Hsisosuchus from Dashanpu, Zigong, Sichuan. Vertebrata Palasiatica 7.

Gasparini, Z., \& D. Dellapé. 1976. Un nuevo cocodrilo marino (Thalattosuchia, Metriorhynchidae) de la Formación Vaca Muerta (Jurásico, Tithoniano) de la Provincia de Neuquén; pp. C1-C21 in Actas I Congresso Geológico Chileno, Santiago, Chile.

Gasparini, Z., \& G. C. Díaz. 1977. Metriorhynchus casamiquelai n. sp. (Crocodilia, Thalattosuchia) a marine crocodile from the Jurassic (Callovian) of Chile, South America. Neues Jahrbuch fur Geologie und Palaontologie, Abhandlungen 153:341-360.

Gasparini, Z. 1980. Un nuevo cocodrilo marino (Crocodylia, Metriorhynchidae) del Caloviano del norte de Chile. Ameghiniana 17:97-103.

Gasparini, Z. 1984. New Tertiary Sececosuchia (Crocodylia:Mesosuchia) from Argentina. Journal of Vertebrate Paleontology 4:85-95.

Gasparini, Z., A. P. Carabajal, \& G. Chong. 2008. Un nuevo espécimen de cocodrilo marino del Jurásico Medio del norte de Chile: revalidación de Metriorhynchus westermanni (Crocodyliformes: Metriorhynchidae). Revista Geológica de Chile 35:335-346.

Georgi, J. A., \& D. W. Krause. 2010. Postcranial axial skeleton of Simosuchus clarki (Crocodyliformes: Notosuchia) from the Late Cretaceous of Madagascar. Journal of Vertebrate Paleontology 30:99-121.

ow, C. E., \& J. W. Kitching. 1988. Early Jurassic crocodylomorphs from the stromberg of South Africa. Neues Jahrbuch fur Geologie und Palaontologie, Monastshefte 9:517-536.

Haughton, S. H. 1915. A new thecodont from Stormberg Beds. Annals of South African Museum 12:98-105. 
Herrera, Y., M. Fernandez, \& J. A. Varela. 2009. Morfología del miembro anterior de Geosaurus araucanensis Gasparini y Dellapé, 1976 (Crocodyliformes: Thalattosuchia). Ameghiniana 46:657-667.

Hecht, B. M., \& S. F. Tarsitano. 1983. On the cranial morphology of the Protosuchia, Notosuchia and Eusuchia. Neues Jahrbuch fur Geologie und Palaontologie, Monastshefte 11:657-668.

Hecht, M. K. 1991. Araripesuchus Price, 1959; pp. 342-347 in J. G. Maysei (ed.), Santana Fossils. T. F. H. Publications, New Jersey.

Hill, R. V. 2010. Osteoderms of Simosuchus clarki (Crocodyliformes: Notosuchia) from the Late Cretaceous of Madagascar. Journal of Vertebrate Paleontology 30:154-176.

Holliday, C. M., \& L. M. Witmer. 2009. The epipterygoid of Crocodyliforms and its significance for the evolution of the orbitotemporal region of eusuchians. Journal of Vertebrate Paleontology 29:715-733.

Iordansky, N. N. 1973. The Skull of the Crocodylia; pp. 201-262 in C. Gans (ed.), Biology of Reptilia. Academic Press, New York.

Iori, F. V., \& I. S. Carvalho. 2009. Morrinhosuchus luziae, um novo Crocodylomorpha Notosuchia da Bacia Bauru, Brasil. Revista Brasileira de Geociências 39:717-725.

Jouve, S. 2005. A new description of the skull of Dyrosaurus phosphaticus (Thomas, 1893) (Mesoeucrocodylia: Dyrosauridae) from the Lower Eocene of North Africa. Canadian Journal of Earth Sciences 42:323-337.

Karl, H.-V., E. Gröning, C. Bauckmann, \& N. Knötschke. 2006. Revision of the enus Enaliosuchus Koken, 1883 (Archosauromorpha: Metriorhynchidae) from the Early Cretaceous of Northwestern Germany. Studia Geologica Salmanticensia 42:49-59.

Kellner, A. W. A., R. G. Figueiredo, R. P. Azevedo, \& A. C. A. Campos. 2011b. A new cretaceous notosuchian (Mesoeucrocodylia) with bizarre dentition from Brazil. Zoological Journal of the Linnean Society 163:S109-S115.

Langston, J. W. 1965. Fossil crocodilians from Colombia and the Cenozoic history of the Crocodilia in South America. Publications in Geological Sciences, University of California 52:1-157.

Li, J., X.-C. Wu, \& X. Li. 1994. New Material of Hsisosuchus chungkingensis from Sichuan, China. Vertebrata Palasiatica 4:107-126. 
Lu, J.-C., and X.-C. Wu. 1994. Restudy of Shantungosuchus brachycephalus Young, 1982. Vertebrata Palasiatica 3:184-201.

Martinelli, A. G., \& D. F. Pais. 2008. A new baurusuchid crocodyliform (Archosauria) from the Late Cretaceous of Patagonia (Argentina). Systematic Palaeontology 7:371-381.

Medem, F. 1981. Los Crocodylia de Colombia. Universidad Nacional de Colombia, Bogota.

Medem, F. 1983. Los Crocodylia de Sur America vol. 2. Universidad Nacional de Colômbia, Bogota.

Meers, M. B. 2003. Crocodylian forelimb musculature and its relevance to Archosauria. The Anatomical Record Part A 274A:891-916.

Meyer, H. 1841. Pholidosaurus schaumbergensis n. gen. n. sp. Neues Mineralogie 1841:343-345.

Molnar, R. 2010. A new reconstruction of the skull of Sebecus icaeorhinus (Crocodyliformes: Sebecosuchia) from the Eocene of Argentina. Brazilian Geographical Journal: Geosciences and Humanities research medium 2:314-330.

Mook, C. C. 1924. A new crocodilian from Mongolia. American Museum Novitates 117:1-5.

Mook, C. C. 1934. A new species of Teleorhinus from the Benton Shales. American Museum Novitates 702:1-11.

Mook, C. 1942. Skull characters of Amphicotylus lucasii. American Museum Novitates 1165:1-5.

Mook, C. 1967. Preliminary description of a new goniopholid crocodilian. Kirtlandia 2:1-10.

Nascimento, P. M., \& H. Zaher. 2010. A new species of Baurusuchus (Crocodyliformes, Mesoeucrocodylia) from the Upper Cretaceous of Brazil, with the first complete postcranial skeleton described for the family Baurusuchidae. Papéis Avulsos de Zoologia 50:323-361.

Nash, D. 1968. A crocodile from the Upper Triassic of Lesotho. Journal of Zoology: Proceedings of the Zoological Society of London 156:163-179.

Nash, D. 1975. The morphology and relationships of a crocodilian, Orthosuchus stormbergi, from the Upper Triassic of Lesotho. Annals of South African Museum 67:227-329.

Nobre, P. H., \& I. S. Carvalho. 2002: Osteologia do crânio de Candidodon itapecuruense (Crocodylomorpha, Mesoeucrocodylia) do Cretáceo do Brasil. Simpósio Sobre o Cretáceo no Brasil, 6 Simpósio sobre el Cretácico de América del Sur, Rio Claro, 2002.

Nobre, P. H., \& I. S. Carvalho. 2006. Adamantinasuchus navae: A new Gondwanan Crocodylomorpha (Mesoeucrocodylia) from the Late Cretaceous of Brazil. Gondwana Research 10:370-378. 
Nobre, P. H. 2004. Morfologia pós-craniana de Candidodon itapecuruense. Revista Brasileira de Paleontologia 7:87-92.

Nobre, P. H., I. S. Carvalho, F. M. Vasconcellos, \& W. R. Nava. 2007. Mariliasuchus robustus, um novo Crocodylomorpha (Mesoeucrocodylia) da Bacia Bauru, Brasil. Anuário do Instituto de Geociências - UFRJ 30:32-43.

Ősi, A., \& D. B. Weishampel. 2009. Jaw mechanism and dental function in the late cretaceous basal eusuchian Iharkutosuchus. Journal of Morphology 278:903-920.

Osmólska, H. 1972. Preliminary note on a crocodilian from the Upper Cretaceous of Mongolia. Palaeontologia Polonica 27.

Owen, R. 1878. Monograph on the fossil Reptilia of the Wealden and Purbeck formations. Supplement No. VIII. Crocodilia (Goniopholis, Petrosuchus and Suchosaurus). Monograph of the Palaeontographical Society 32:1-15.

Peng, G. Z. 1996. A Late Jurassic Protosuchian Sichuanosuchus huidongensis from Zigong, Sichuan Province. Vertebrata Palasiatica 34:269-278.

Peng, G.-Z., \& C.-K. Shu. 2005. A new Species of Hsisosuchus from the Late Jurassic of Zigong, Sichuan, China. Vertebrata Palasiatica 10:312-324.

Pinheiro, A. E. P. C., M. B. Andrade, \& R. G. M. Neto. 2008. A new specimen of Stratiotosuchus maxhechti (Baurusuchidae, Crocodyliformes) from the Adamantina Formation (Upper Cretaceous), Southeastern Brazil. Revista Brasileira de Paleontologia 11:37-50.

Pinheiro, A. E. P. C., A. C. A. Campos, \& A. W. A. Kellner. 2011: A new Sebecia (Metasuchia, Crocodyliformes) from the Itaboraí Basin (Paleogene) Rio de Janeiro, Southeast Brazil. IV Congresso Latinoamericano de Paleontología de Vertebrados, San Juan, Argentina, 2011.

Pol, D., and Z. Gasparini. 2007. Crocodyliformes; pp. 116-142 in Z. Gasparini, L. Salgado, and R. A. Coria (eds.), Patagonian Mesozoic Reptiles. Indiana University Press, Bloomington \& Indianapolis.

Rasmusson, E. L. 2008. New material of Trematochampsa oblita (Crocodyliformes, Trematochampsidae) from the Late Cretaceous of Madagascar, with a review and cladistic analysis of the Family Trematochampsidae. Department of Geological Sciences, Michigan State University, $75 \mathrm{pp}$.

Salisbury, S. W. 2002. Crocodilians from the Lower Cretaceous (Berriasian) Purbeck Limestone Group of Dorset, Southern England. Special Papers in Palaeontology 68:121-144. 
Salisbury, S. W., E. Frey, D. M. Martill, \& M.-C. Buchy. 2003. A new crocodilian from the Lower Cretaceous Crato Formation of North-eastern Brazil. Paleontographica 270:3-47.

Schwarz, D., \& S. W. Salisbury. 2005. A new species of Theriosuchus (Atoposauridae, Crocodylomorpha) from the Late Jurassic (Kimmeridgian) of Guimarota, Portugal. Géobios 38:779-802.

Seeley, H. G. 1881. The reptile fauna of the Gosau Formation preserved in the Geological Museum of the University of Vienna. Quarterly Journal of the Geological Society of London 37:620704.

Sertich, J. J. W., and J. R. Groenke. 2010. Appendicular skeleton of Simosuchus clarki (Crocodyliformes: Notosuchia) from the Late Cretaceous of Madagascar. Journal of Vertebrate Paleontology Memoir 10 30, Supplement to Number 6:122-153.

Wu, X.-C., D. B. Brinkman, and A. P. Russel. 1996. Sunosuchus junggarensis sp.nov. (Archosauria: Crocodyliformes) from the Upper Jurassic of Xinjiang, People's Republic of China. Canadian Journal of Earth Sciences 33:606-630.

Wu, X.-C., D. B. Brinkman, and R. C. Fox. 2001. A new crocodylian (Archosauria) from the basal Paleocene of the Red Deer River Valley, southern Alberta. Canadian Journal of Earth Sciences 38:1689-1704.

Wu, X.-C., Z.-W. Cheng, and A. P. Russel. 2001. Cranial anatomy of a new crocodyliform (Archosauria: Crocodylomorpha) from the Lower Cretaceous of Song-Liao Plain, northeastern China. Canadian Journal of Earth Sciences 38:1653-1663. 
APÊNDICE V. Montefeltro, F. C., H. C. E. Larsson, \& M. C. Langer. 2011. A New Baurusuchid (Crocodyliformes, Mesoeucrocodylia) from the Late Cretaceous of Brazil and the Phylogeny of Baurusuchidae. Plos ONE 6:e21916.

Link de acesso ao artigo:

http://www.plosone.org/article/info\%3Adoi\%2F10.1371\%2Fjournal.pone.0 021916 


\title{
A New Baurusuchid (Crocodyliformes, Mesoeucrocodylia) from the Late Cretaceous of Brazil and the Phylogeny of Baurusuchidae
}

\author{
Felipe C. Montefeltro ${ }^{1 *}$, Hans C. E. Larsson ${ }^{2}$, Max C. Langer ${ }^{1}$ \\ 1 Departamento de Biologia, Faculdade de Filosofia, Ciências e Letras de Ribeirão Preto - Universidade de São Paulo, Ribeirão Preto, Brazil, 2 Redpath Museum, McGill \\ University, Montréal, Canada
}

\begin{abstract}
Background: Baurusuchidae is a group of extinct Crocodyliformes with peculiar, dog-faced skulls, hypertrophied canines, and terrestrial, cursorial limb morphologies. Their importance for crocodyliform evolution and biogeography is widely recognized, and many new taxa have been recently described. In most phylogenetic analyses of Mesoeucrocodylia, the entire clade is represented only by Baurusuchus pachecoi, and no work has attempted to study the internal relationships of the group or diagnose the clade and its members.

Methodology/Principal Findings: Based on a nearly complete skull and a referred partial skull and lower jaw, we describe a new baurusuchid from the Vale do Rio do Peixe Formation (Bauru Group), Late Cretaceous of Brazil. The taxon is diagnosed by a suite of characters that include: four maxillary teeth, supratemporal fenestra with equally developed medial and anterior rims, four laterally visible quadrate fenestrae, lateral Eustachian foramina larger than medial Eustachian foramen, deep depression on the dorsal surface of pterygoid wing. The new taxon was compared to all other baurusuchids and their internal relationships were examined based on the maximum parsimony analysis of a discrete morphological data matrix.

Conclusion: The monophyly of Baurusuchidae is supported by a large number of unique characters implying an equally large morphological gap between the clade and its immediate outgroups. A complex phylogeny of baurusuchids was recovered. The internal branch pattern suggests two main lineages, one with a relatively broad geographical range between Argentina and Brazil (Pissarrachampsinae), which includes the new taxon, and an endemic clade of the Bauru Group in Brazil (Baurusuchinae).
\end{abstract}

Citation: Montefeltro FC, Larsson HCE, Langer MC (2011) A New Baurusuchid (Crocodyliformes, Mesoeucrocodylia) from the Late Cretaceous of Brazil and the Phylogeny of Baurusuchidae. PLoS ONE 6(7): e21916. doi:10.1371/journal.pone.0021916

Editor: Andrew Allen Farke, Raymond M. Alf Museum of Paleontology, United States of America

Received March 15, 2011; Accepted June 8, 2011; Published July 13, 2011

Copyright: (c) 2011 Montefeltro et al. This is an open-access article distributed under the terms of the Creative Commons Attribution License, which permits unrestricted use, distribution, and reproduction in any medium, provided the original author and source are credited.

Funding: FAPESP (grant number: 2008/57642-6), Programa de Pós-Graduação em Biologia Comparada, FFCLRP-USP, and Programa Doutorando com Estágio no Exterior, CAPES (grant number 1275/10-0) to FCM, CNPQ and FAPESP to MCL, CRC and NSERC to HCEL. The funders had no role in study design, data collection and analysis, decision to publish, or preparation of the manuscript.

Competing Interests: The authors have declared that no competing interests exist.

* E-mail: felipecm@pg.ffclrp.usp.br

\section{Introduction}

Baurusuchid crocodyliforms have been long recognized by their highly divergent morphology relative to other crocodyliforms. The good preservation of the holotype skull of Baurusuchus pachecoi [1] made the taxon present in nearly every phylogenetic analysis of Crocodyliformes (e. g.: [2-14]). As a consequence, this species plays a central role in interpreting basal crocodyliform evolutionary and biogeographic patterns [2,15-17]. On the other hand, a comprehensive phylogenetic analysis of putative baurusuchids has never been done, and the current and only phylogenetic definition for the clade was not backed up by a phylogenetic analysis [18]. Consequently, baurusuchid membership and internal relationships are not well studied or resolved [19]. Previously assigned taxa from the Late Cretaceous of South America [18,20-23] are commonly accepted as members of the group, but this is more uncertain for fragmentary taxa from Cretaceous deposits of Argentina and Pakistan and Paleogene deposits of Europe and Africa [17,18,24-27]. The baurusuchid affinity of these forms is debated, and many current analyses do not support this association [9,19,28-31]. Baurusuchus is certainly a key taxon in crocodyliform phylogeny, but its use as the only baurusuchid in phylogenetic analyses (e. g.: [9,13,32-34]) underestimates the morphological diversity of the clade and may influence results because of its derived characters.

Here we describe a new baurusuchid based on a well preserved skull and a referred partial skull and lower jaw. The specimens are accessioned in the collection of the Laboratório de Paleontologia de Ribeirão Preto (LPRP), Faculadade de Filosofia Ciências e Letras de Ribeirão Preto (FFCLRP), Universidade de São Paulo (USP) as LPRP/USP 0018 and LPRP/USP 0019, and come from the municipality of Campina Verde, in the region known as Triângulo Mineiro, Minas Gerais state, Brazil (Figure 1). The material was collected in June 2008 during ongoing systematic field work by members of the Laboratório de Paleontologia de Ribeirão Preto, FFCLRP-USP, from deposits of 

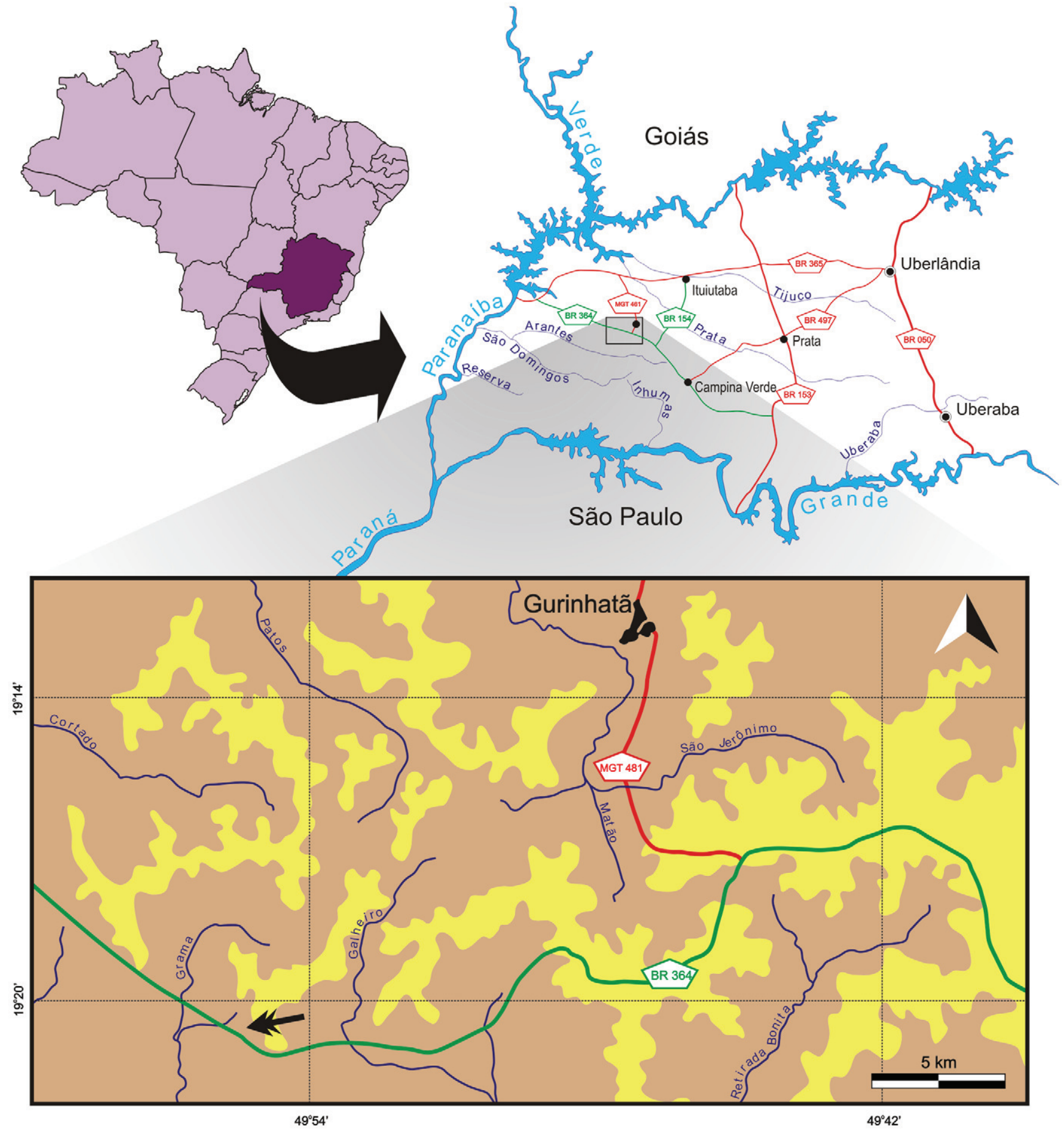

Figure 1. Map of the area where Pissarrachampsa sera was collected. Area highlighted in maps of Brazil, Minas Gerais (above on the left), and the Triângulo Mineiro region (above on the right). Main river courses indicated in blue, paved roads in red, and secondary non-paved roads in green. Surface distribution of the Bauru Group rocks based on [106]: beige = Vale do Rio do Peixe Formation; yellow = Marília Formation.

doi:10.1371/journal.pone.0021916.g001

the Vale do Rio do Peixe Formation (Figure 2), which is composed of fine-grained sandstones with sandy-mudstone contributions deposited under a continental, semi-arid climate $[35,36]$.

The new taxon is undoubtedly a baurusuchid, based on its derived dog-like skull and hypertrophied canines. We tested the taxon's phylogenetic position with the first comprehensive analysis of the better known putative bauruschids. Characters in the phylogenetic analysis were compiled from previous studies, and a suite of new characters were added to account for previously unrecognized transformation series. The analysis clarifies the neglected internal relationships of Baurusuchidae and presents a set of new apomorphies for the clade. We also present a set of formal definitions for the group. 


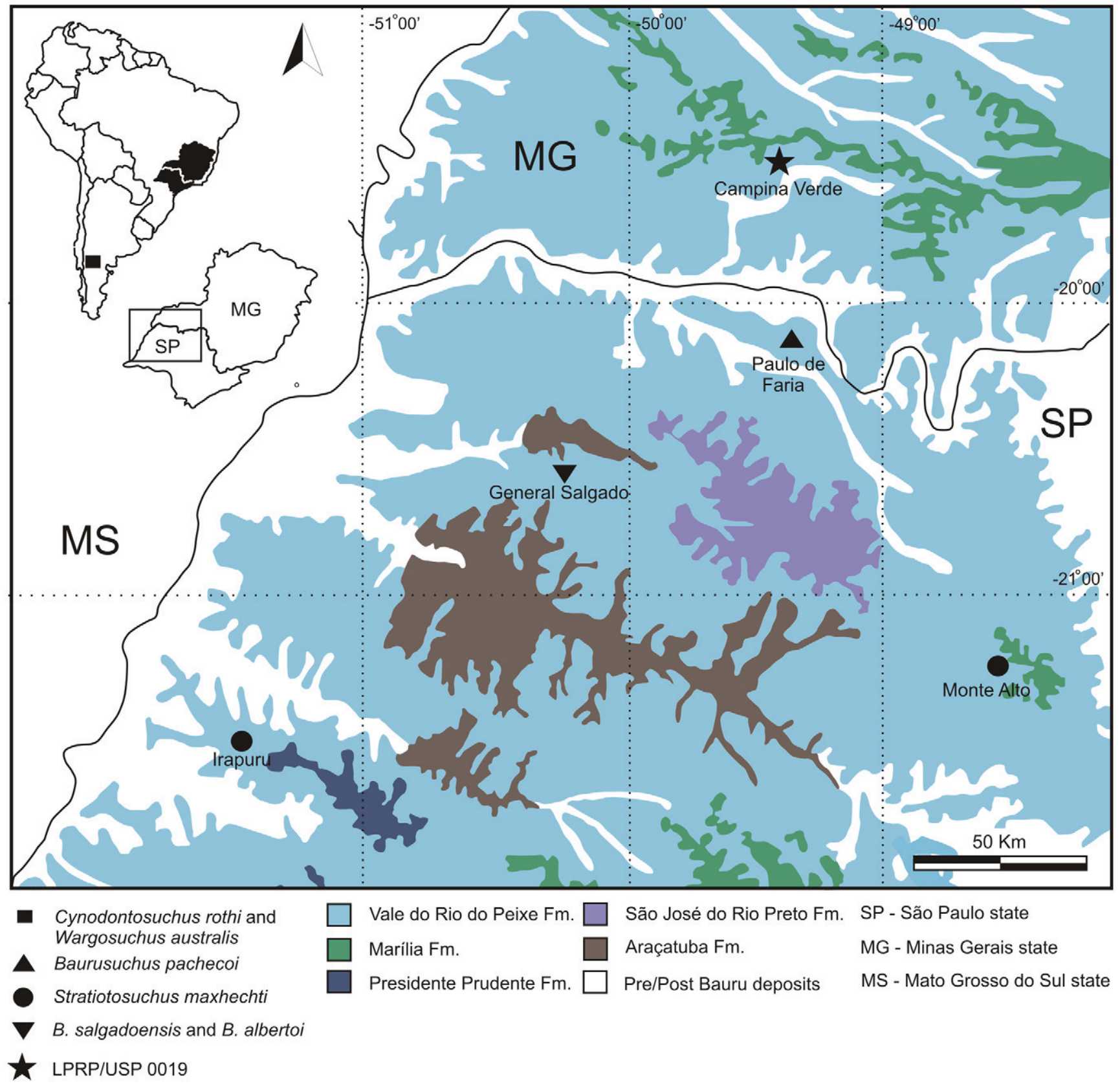

Figure 2. Surface distribution of the Bauru Group rocks. The northeastern portion of the Bauru Basin (São Paulo and Minas Gerais states), depicting the localities where Baurusuchidae fossils were collected (modified from [107]).

doi:10.1371/journal.pone.0021916.g002

\section{Methods}

\section{Preparation}

The fossil material was mechanically prepared using pin vice and pneumatic air scribe. Paraloid B72 dissolved in acetone was used for surface consolidation and as an adhesive.

\section{Nomenclatural Acts}

The electronic version of this document does not represent a published work according to the International Code of Zoological Nomenclature (ICZN), and hence the nomenclatural acts contained in the electronic version are not available under that Code from the electronic edition. Therefore, a separate edition of this document was produced by a method that assures numerous identical and durable copies, and those copies were simultaneously obtainable (from the publication date noted on the first page of this article) for the purpose of providing a public and permanent scientific record, in accordance with Article 8.1 of the Code. The separate print-only edition is available on request from PLoS by sending a request to PLoS ONE, 185 Berry Street, Suite 3100, San Francisco, CA 94107, USA along with a check for $\$ 10$ (to cover printing and postage) payable to "Public Library of Science". In addition, this published work and the nomenclatural acts it contains have been registered in ZooBank, the proposed online registration system for the ICZN. The ZooBank LSIDs (Life Science Identifiers) can be resolved and the associated information 
viewed through any standard web browser by appending the LSID to the prefix "http://zoobank.org/". The LSID for this publicaftion is: urn:lsid:zoobank.org:pub:023DCB79-D033-4FB0-81C0$28302 \mathrm{E} 440 \mathrm{E} 15$.

\section{Ethics statement}

No live animals were used in this study.

\section{Field work permission}

The permission for fossil collection was obtained from Deparftamento Nacional de Produção Mineral (document: 36/DIFIS) based on ordinance $n^{\circ} 4.146$ from $4^{\text {th }}$ March, 1942.

\section{Systematic paleontology \\ Crocodyliformes Benton \& Clark 1988 [2] \\ Mesoeucrocodylia Whetstone \& Whybrown 1983 [37] sensu}

Benton \& Clark 1988 [2]

Baurusuchidae Price, 1945 [1]

Pissarrachampsa gen. nov.

Derivation of name. The generic epithet is a combination of the local name for the fossil bearing sandstones, piçarra, and the Greek suffix $X \dot{\alpha} \mu \psi \alpha \iota$ (latinized as "champsa") meaning crocodile.

Type species. Pissarrachampsa sera

urn:lsid:zoobank.org:act:F69BDAD1-38B7-4F89-95912C503826C91E

Diagnosis. Same as for the only known species.

Pissarrachampsa sera gen. et. sp. nov. (Figures 3, 4, 5, 6, 7, 8, $9,10,11,12,13,14,15$ and 16 )

urn:lsid:zoobank.org:act:AF7428F1-B88C-4212-A543-666593C7 5340

Derivation of name. The specific epithet is a Latin word meaning 'late', in reference to the collection of the holotype. It was the last fossils found during the 2008 expedition and were about to be left behind because of the tight schedule. In addition, sera is also a homage to the Minas Gerais state, where the fossils were found, the flag of which contains Virgil's inscription: "Libertas Quæ Sera Tamen" meaning "Freedom Albeit Late".

Holotype. LPRP/USP 0019 is a nearly complete cranium, lacking only the anteriormost portion of the rostrum, right palpebrals, and mandibles.

Referred specimen. LPRP/USP 0018 is a partial rostrum and anterior palate with the anterior portion of the mandibles articulated.

Type locality. Inhaúmas-Arantes Farm, Campina Verde municipality, Minas Gerais, Brazil (19 $20^{\prime} 41.8^{\prime \prime} \mathrm{S}$; 49 $55^{\prime} 12,9^{\prime \prime}$ W).

Age and horizon. Vale do Rio do Peixe Formation, Bauru Group, Bauru Basin; Late Cretaceous (Turonian-Santonian or Campanian-Maastrichtian, but see discussion).

Diagnosis. Baurusuchid with four maxillary teeth, a longitudinal depression on the anterior portion of frontal, frontal longitudinal ridge extending anteriorly overcoming the frontal midlength, supratemporal fenestra with equally developed medial and anterior rims, lacrimal duct at the corner formed by the dorsal (support for anterior palpebral) and lateral lacrimal surfaces, well developed rounded foramen between the palpebrals, quadratojugal and jugal do not form a continuous ventral border (a notch is present due to the ventral displacement of the quadratojugal), four quadrate fenestrae visible laterally, quadrate lateral depression with anteroposteriorly directed major axis, sigmoidal muscle scar in the medial surface of the quadrate (ridge 'A'), ectopterygoid almost reaching the posterior margin of the pterygoid wings, a single ventral parachoanal fenestra, and one ventral parachoanal fossa (divided into medial and lateral parachoanal subfossae), lateral Eustachian foramina larger than the medial one, and a deep depression on the posterodorsal surface of the pterygoid wings.

\section{Description}

The anatomical description and soft tissue inferences will follow $[9,38-44]$ as much as possible. The dental description follows the definitions and nomenclature of $[45,46]$. The supratemporal morphology of baurusuchids differs from many crocodyliforms in that the dorsal and ventral portions of the supratemporal chamber are demarcated by a distinct ridge. We will follow the argumentation of [47], regarding the antorbital fenestra, and describe the dorsal and ventral portions of the supratemporal chamber as external and internal, respectively. The dorsal surfaces of the bones surrounding the supratemporal fenestrae are often excavated into a depression usually termed the supratemporal fossa, which is also used here. The dorsal peripheral rim of the fossa marks the external supratemporal fenestra and roughly corresponds to the "supratemporal fenestra" as traditionally used. The bony edge ventral to the supratemporal fossa is the internal supratemporal fenestra. The internal and external supratemporal fenestrae are hard to distinguish in Crocodyliformes with a poorly developed supratemporal fossa; i.e., in some eusuchians there is only a single fenestra. This becomes more complicated because of the verticalization of the supratemporal fossa, the unequally developed regions of the fossa, and the confluence of the supratemporal fossa with the lateral surface of the orbitotemporal bones in some groups. However, for Pissarrachampsa sera and other baurusuchids, the separation between external and internal supratemporal fenestrae is useful.

\section{Cranium}

The following anatomical description is primarily based on the cranium LPRP/USP 0019 (Figures 3,4,9, 10, 11, 12, 13, 14, 15). LPRP/USP 0018 (Figures 6, 7, 8, 16) is also employed in the description of the anterior portion of rostrum, mandible and dentition, and the minor morphological differences on their overlapping elements are discussed when they occur. The more evident preservational deficiencies of the holotype specimen are the lack of the anterior portion of the rostrum due to erosion, the loss of the right palpebral bones, and fractures on the occipital region and quadrate condyles. Some minor damages and breakages in the skull roof, braincase, and palatal region are also present. As a result of pressure inflicted during fossilization, the sides of the snout and the pterygoid wings are no longer symmetrically aligned, so that the skull appears twisted towards the right when viewed from the front and from behind. Also as an effect of such distortion, the right postorbital bar is broken at the level of the postorbital-jugal contact, and its dorsal tip pierces the postorbital descending flange.

In dorsal view, LPRP/USP 0019 has a triangular shape. The combined morphologies of LPRP/USP 0018 and 0019 allow the reconstruction of a relatively short snout (Table 1-2, Figure 3,4,6,7). The maximum length of the preserved rostrum of LPRP/USP 0019 is about $42 \%$ of the basal skull length. The complete preorbital length is estimated to be approximately $70 \%$ of the entire skull length, placing Pissarrachampsa in the category of short snouted Crocodyliformes [38]. The snout is not conspicuously constricted in relation to the postorbital portion of the skull, and the skull table is continuous with the dorsal surface of the snout. The external surfaces of most of the superficial dermal bones are sculptured with irregular pits and ridges. This sculpturing is pronounced on the prefrontal, anterior portion of the frontal, postorbital dorsal surface, jugal, and squamosal and is 


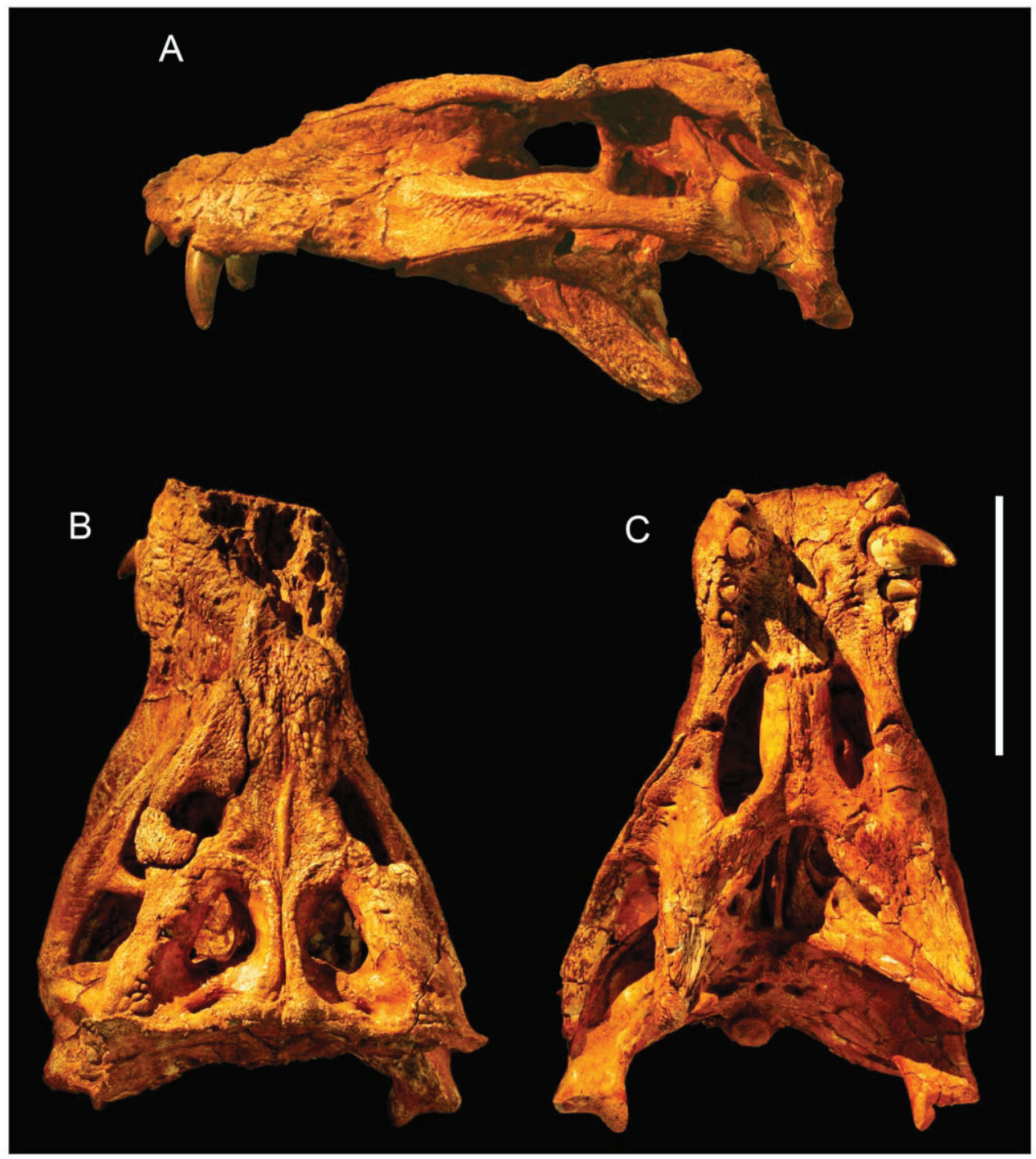

Figure 3. Skull of the baurusuchid Pissarrachampsa sera (LPRP/USP 0019, holotype). A) lateral; B) dorsal; C) ventral views. B and C have depth of field calibrated to the skull table and palatal plane respectively. Scale bar equals $10 \mathrm{~cm}$. doi:10.1371/journal.pone.0021916.g003

completely absent on the supratemporal fossa, postorbital descending flange, and all but the ventral portion of the quadratojugal.

The external nares are partially preserved in LPRP/USP 0018. They face anteriorly and were probably completely divided. The antorbital fenestra is completely closed without even a trace of the antorbital fossa. The orbits are subcircular and face anterolaterally. The anterior and posterior portions of the orbits are roofed by thick palpebrals. The external supratemporal fenestra is nearly equal in size to the orbit, and the internal supratemporal fenestra is only about half of the orbit size. The supratemporal fenestrae are longer than wide and triangular in dorsal aspect with a wide posterior margin. The triangular infratemporal fenestra is smaller than the orbit and the external supratemporal fenestra, but larger than the internal supratemporal fenestra. The infratemporal fenestra real orientation is hard to determine given the distortion of the skull. On the right side, the infratemporal fenestra faces laterally, but faces dorsolaterally on the left side. In both sides, it faces slight anteriorly. The suborbital fenestra is large, and its long axis is oriented anteroposteriorly. The choanae are wide and, together with the parachoanal structures, occupy a great part of the posterior palate. The choanae face ventrally and are limited anteriorly and anterolaterally by the palatines and ectopterygoid, and posteriorly by the pterygoid. The choanae are lozenge shaped, with the greatest axis oriented transverse of skull major axis. The anteroposterior axis is divided by a median bony septum formed by the pterygoids. The occipital region is partly damaged in LPRP/USP 0019, but a post-temporal fenestra is not present.

Only a small portion of the paired premaxillae is present as a round suture just posterior to the preserved anteroventral limit of LPRP/USP 0019. A nearly complete right premaxilla is preserved in LPRP/USP 0018. The premaxilla bounds the anteroventral, ventral, posterior, and posterodorsal edges of external nares. The nares are surrounded by a broad circumnarial fossa that faces anteriorly on its posterior portion and is not visible in lateral view (Figure 8). A short, but damaged, median protuberance is present in the ventral narial margin, suggesting that a slight infranarial prong may have contributed to the internarial bar. An obvious, small vascular foramen occurs at the lateral base of this median protuberance, and no other foramina are visible in the 

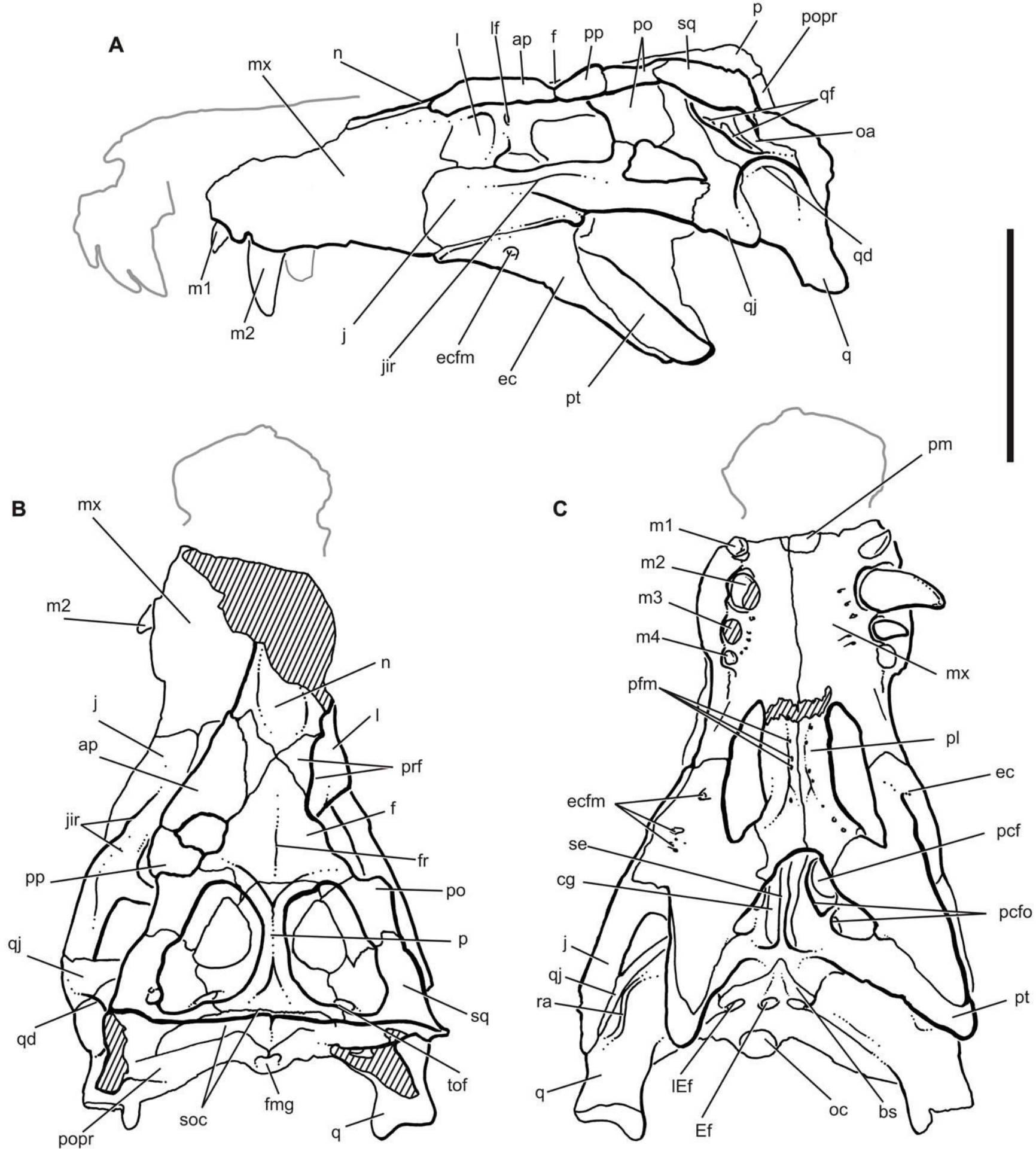

Figure 4. Skull of the baurusuchid Pissarrachampsa sera. A) and C) Drawing of the skull LPRP/USP 0019 (holotype) in strict lateral (left) and ventral views, respectively. B) Reconstruction of the dorsal surface of the same skull, based on a strict dorsal view of skull roof and a slightly posterodorsal view of the occipital plane. Hatched areas indicate broken surfaces. Reconstruction of the anterior part of the rostrum based on the referred specimen (LPRP/USP 0018). Abbreviations: ap, anterior palpebral; bs, basisphenoid; cg, choanal groove; ec, ectopterygoid; ecfm, ectopterygoid foramina; Ef, medial Eustachian foramen; f, frontal; fmg, foramen magnum; fr, frontal ridge; j, jugal; jir, jugal infraorbital ridge; l, lacrimal; IEf, lateral Eustachian foramen; If, lacrimal duct foramen; mx, maxilla; m1-m4, maxillary teeth (1-4); $\mathrm{n}$, nasal; oa, otic aperture; oc, occipital condyle; $\mathrm{p}$, parietal; pcf, parachoanal fenestra; pcfo, parachoanal fossae; pfm, palatine foramina; pfp, pl, palatine; pm, premaxilla; po, postorbital; popr, paraoccipital process; pp, posterior palpebral; prf, prefrontal; pt, pterygoid; q, quadrate; qd, quadrate depression; qf, quadrate fenestrae; qj, quadratojugal; ra, ridge 'A'; se, choanal septum; soc, supraoccipital; sq, squamosal; tof, temporo-orbital foramen. Scale bar equals $10 \mathrm{~cm}$. doi:10.1371/journal.pone.0021916.g004 

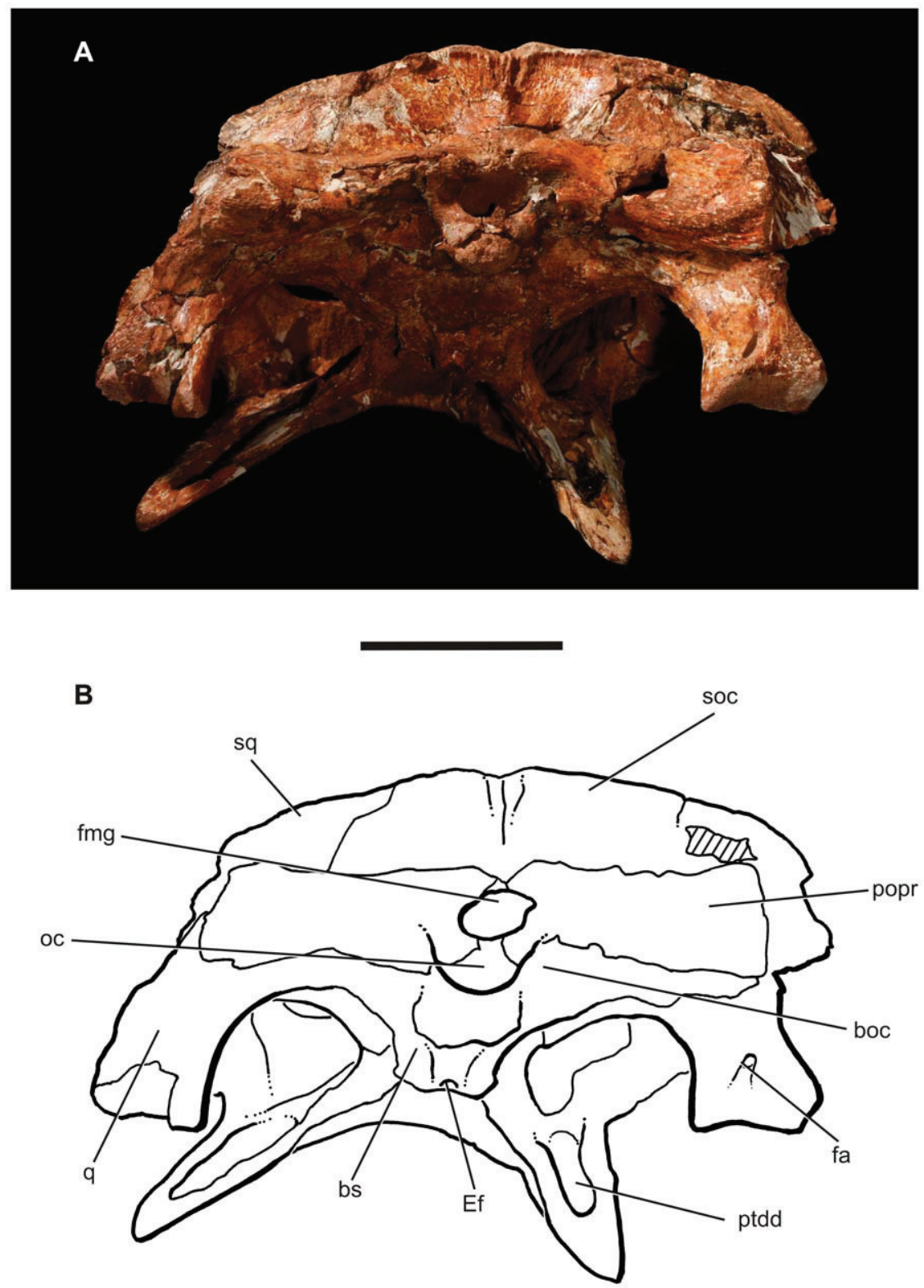

Figure 5. Skull of the baurusuchid Pissarrachampsa sera (LPRP/USP 0019, holotype). A) occipital view; B) interpretive drawing of the occipital view. Abbreviations: boc, basioccipital; fa, foramen aërum; ptdd, pterygoid dorsal depression. Scale bar equals $5 \mathrm{~cm}$. doi:10.1371/journal.pone.0021916.g005

circumnarial fossa. The dorsal limit of the premaxilla arches over the external nares as a robust process and likely supported the lateral base of an internarial bar. The medial surface of this process preserves a fluted edge that would have contacted the right lateral edge of the nasal.

A large, laterally facing notch is present at the lateral premaxilla-maxilla suture. This notch curves ventromedially towards the palate and received an enlarged dentary caniniform tooth $(\mathrm{d} 4)$. The notch is large enough to create a diastema between the premaxillary and maxillary dentition and a constriction in the rostrum in dorsal and lateral profiles. The exact position of the premaxilla-maxilla suture within the notch is not visible. The premaxilla has three teeth with subcircular alveolar cross-sections. The first and second are similar in size, whereas the third is hypertrophied. A deep pit is located between, and slightly distal to, the first two alveoli and probably received the first dentary tooth.
The anteroposteriorly short and dorsoventrally deep maxillae are oriented nearly vertically, comprise most of the sidewalls of the snout, and have nearly no participation in the dorsal surface of the skull. Only four teeth are housed in the maxilla. The first alveolus is relatively small and faces anteroventrally. The second alveolus has the largest anteroposterior length, with an anteroposterior length greater than the other three alveoli and opens ventrally. The third and fourth alveolus are intermediate in size and open posteroventrally. In lateral aspect, the alveolar margin is ventrally arched reaching the greatest depth at the second maxillary tooth. The short tooth row does not extent far, ending posteriorly at the level of the arched maxillary alveolar margin and well anterior to the orbits. A reduced groove with a rugose surface extends posteriorly from the tooth row. This structure may represent a remnant of the alveolar groove. An elongate groove to house the posterior teeth is common in many eusuchians. The presence of 


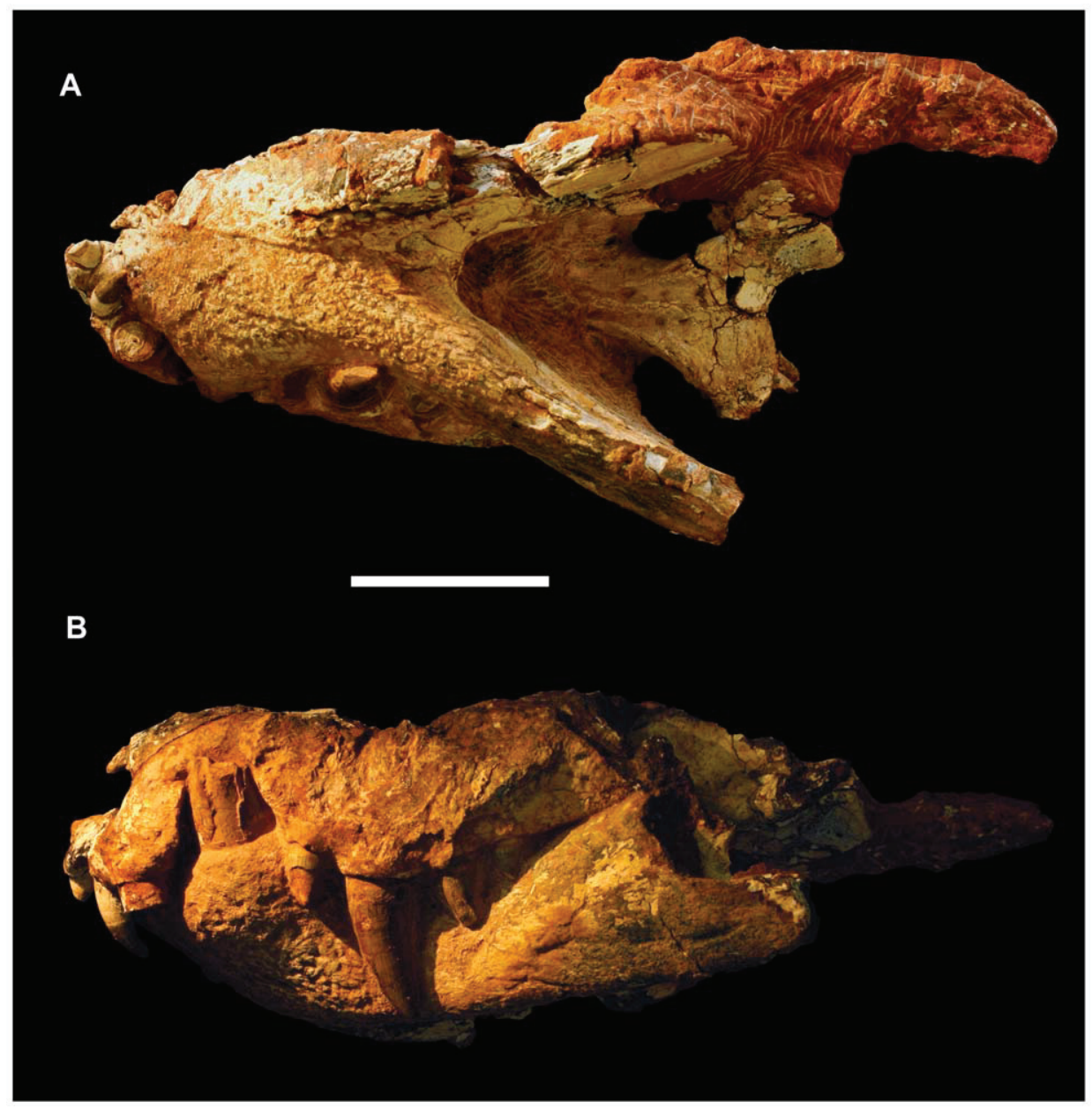

Figure 6. Skull of the referred specimen of Pissarrachampsa sera (LPRP/USP 0018). A) ventral; B) lateral (mirrored) views. Scale bar equals $5 \mathrm{~cm}$.

doi:10.1371/journal.pone.0021916.g006

this restricted and toothless groove in Pissarrachampsa suggests its highly reduced tooth formula in the maxilla may be the result of loss of posterior teeth and subsequent closing of the alveolar groove during ontogeny. The lateral wall of the maxilla extends back to the level of palpebral support structures. The tooth rows are slightly arched outwards, and both ends tend to converge to their counterparts in the opposite maxilla. The internal and external alveolar walls are not symmetrical; the latter is more ventrally developed, and the lingual tooth surfaces are further exposed. Posterolaterally, the maxilla contacts the jugal and lacrimal with a short posterior projection wedged between those bones, which does not reach the orbital margin. Numerous foramina dot the palatal shelf of the maxilla just lingual to the tooth row. A deep occlusal pit for the reception of a large dentary tooth is situated immediately lingual to the alveolus of $\mathrm{m} 3$ and $\mathrm{m} 4$. An additional occlusal pit occurs on the left maxilla, medially displaced at the level of teeth $3-4$ as well as small aligned deformations in palatal surface indicating a complete overbite.

Medially, the palatal shelves of the maxillae meet to form an extensive secondary bony palate. A deep longitudinal groove is present over most of the palatal shelf midline suture. This is most pronounced throughout the mid-length where three well defined foramina are also visible. The groove partially obscures the sutural contact between maxillae. Posteriorly, the groove graduates into the flat posterior maxillary palatal surface. A pair of foramina is present on the maxillary portion of the palate near the maxillapalatine contact and appears to represent posterior extensions of the foramina of the midline groove. The palatal maxilla-palatine suture extends transversely from the midline to the medial borders of the suborbital fenestrae. Each maxilla posseses a lateral palatal ramus which extends posteriorly and abuts the ectopterygoid at the level of the midpoint of the suborbital fenestra, causing the maxilla to border not only the anterior portion of suborbital fenestra, but also its anterolateral half.

The jugal is long and transversely narrow. Its anterior (infraorbital) process expands greatly from the midlength until the contact with the maxilla and lacrimal. The orbital margin of the jugal posseses a low border that extends slightly lateral to the anterior margin of the postorbital bar. This configuration makes the anterior margin of this bar slightly inset from the outer orbital surface of the jugal. In addition, the postorbital bar does not have the sculptured pattern present in surrounding surfaces. The lateral surface of this process has a long ridge that spans the entire length of the infraorbital process at approximately midheight (Figure 10). The ridge, which we call the infraorbital ridge, arises anteriorly at the level of lacrimal and extends posteriorly to the round posterior (infratemporal) ramus. A longitudinal depression extends dorsal to this ridge from the anterior third of the orbital length and ends posterior to the postorbital bar. At both ends, this depression graduates to the jugal surface. A broad, fan-shaped, shallow 

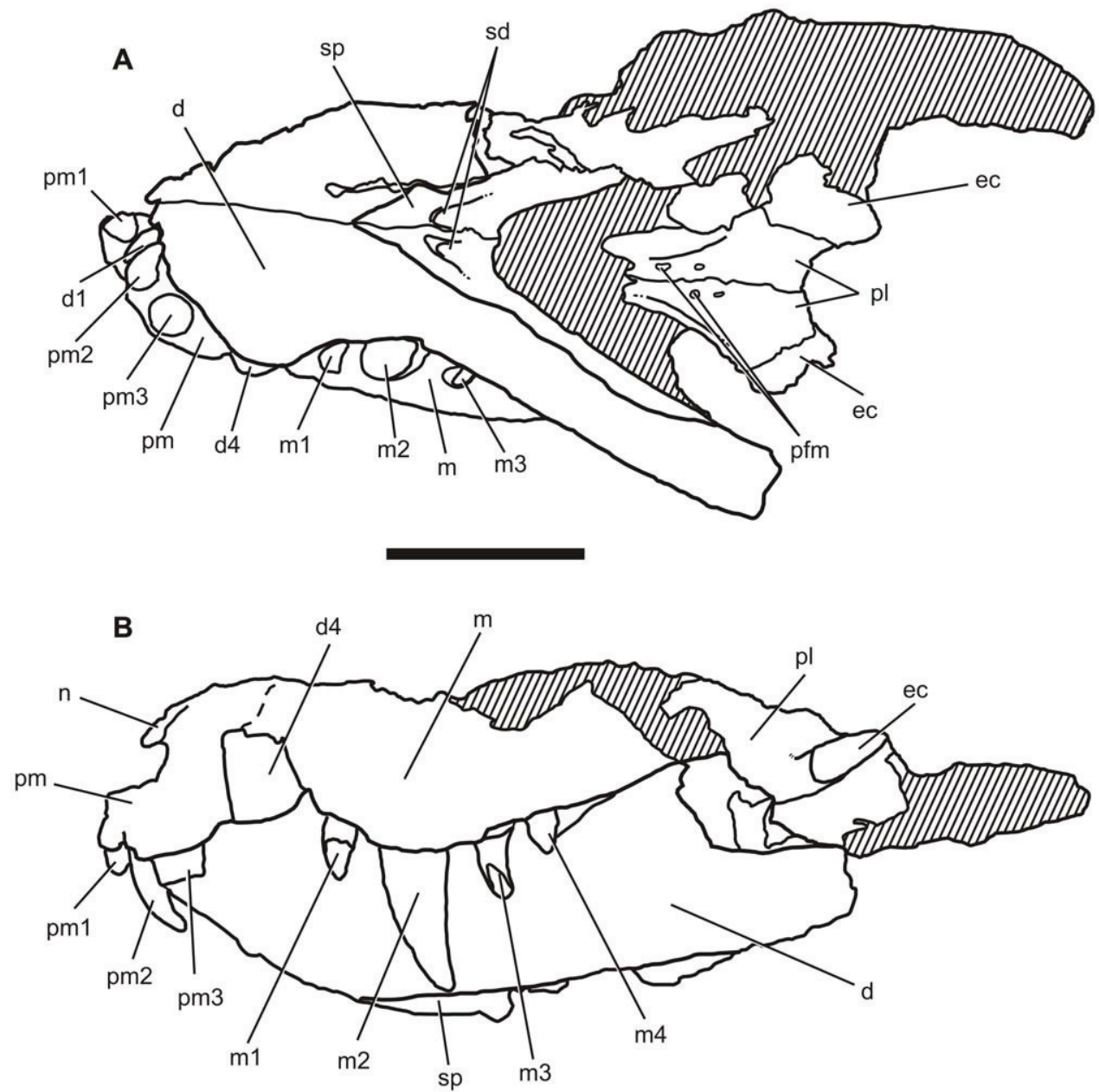

Figure 7. Drawing of the skull of the referred specimen of Pissarrachampsa sera (LPRP/USP 0018). A) ventral; B) lateral (mirrored). Dashed line represents possible premaxilla-maxilla suture. Hatched areas indicate broken surfaces and matrix. Abbreviations: $d$, dentary; d1, dentary tooth 1; d4, dentary tooth 4; premaxilla; pm1-pm3, premaxillary teeth 1-3; sd, splenial depressions; sp, splenial. Scale bar equals $5 \mathrm{~cm}$. doi:10.1371/journal.pone.0021916.g007

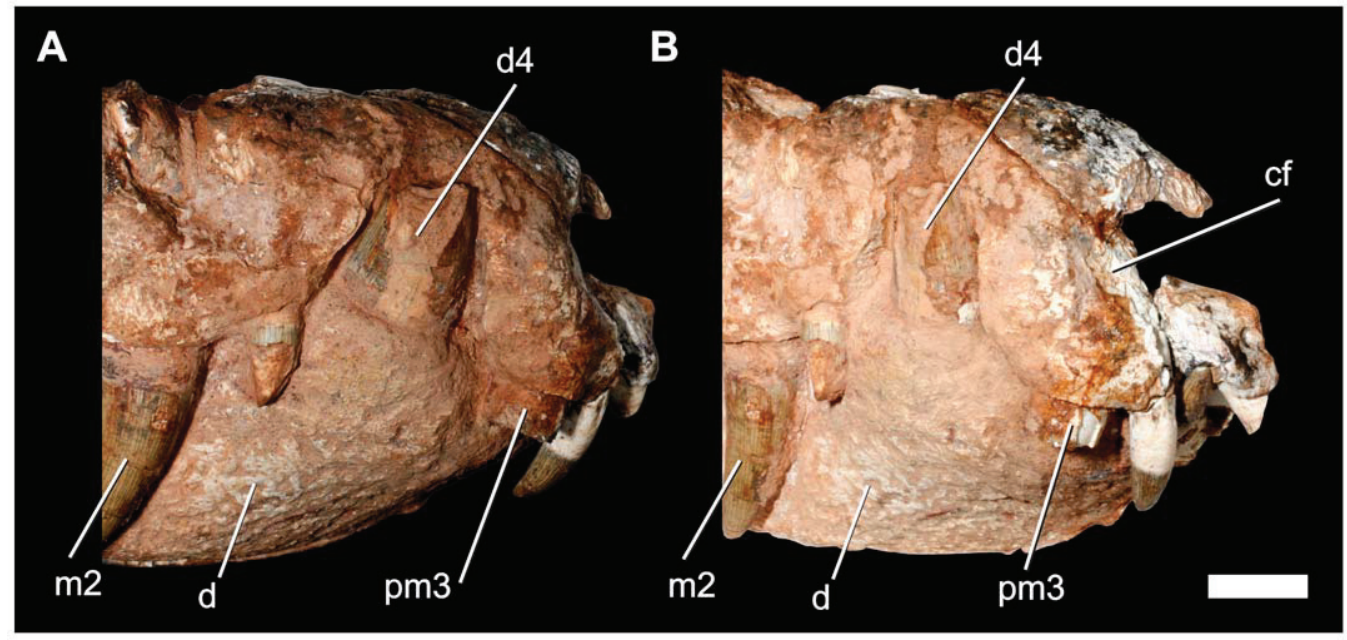

Figure 8. Details of the right anteriormost portion of the rostrum of Pissarrachampsa sera (LPRP/USP 0018). A) lateral; B) anterolateral views. Abbreviation: $\mathrm{cf}$, circumnarial fossa. Scale bar equals $1 \mathrm{~cm}$.

doi:10.1371/journal.pone.0021916.g008 


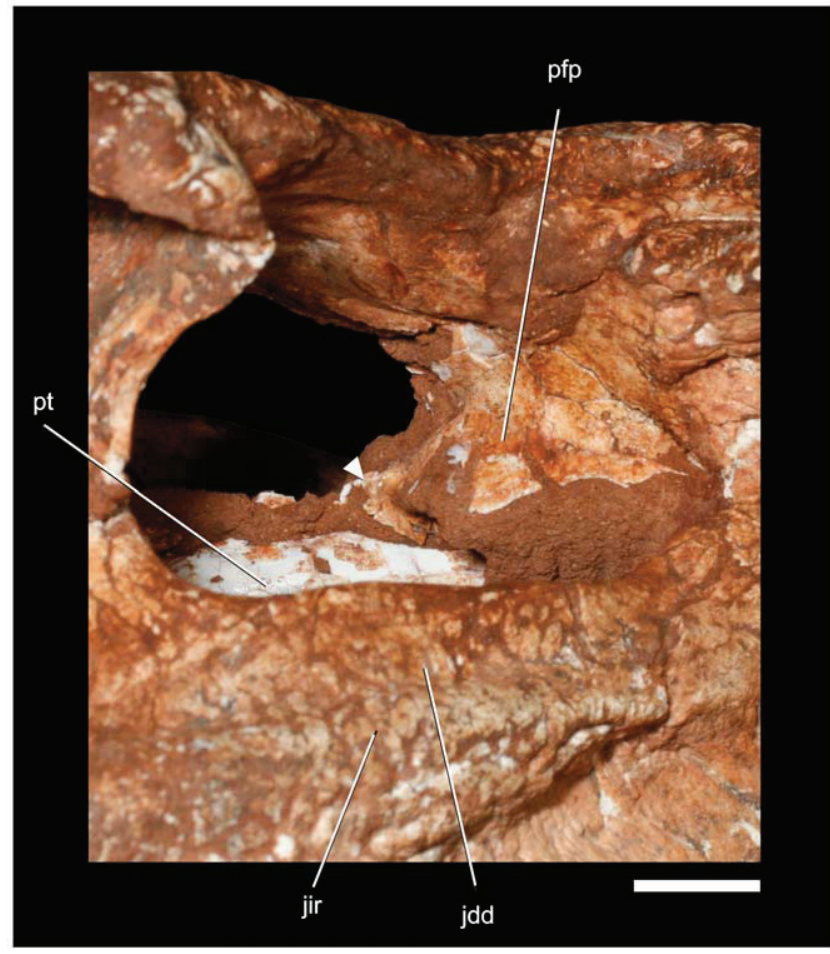

Figure 9. Details of the right prefrontal pillar of Pissarrachampsa sera (LPRP/USP 0019) through the orbit. Arrow points to the medioventral extension of prefrontal pillar. Abbreviations: jdd, jugal dorsal depression; pfp, prefrontal pillar. Scale bar equals $1 \mathrm{~cm}$. doi:10.1371/journal.pone.0021916.g009

depression occurs ventral to the ridge. Indeed, the ridge is a combination of a lateral hypertrophy of the jugal and the occurrence of shallow depressions dorsal and ventral to it. The surface of this depression is strongly sculpted and presents a reduced series of neurovascular foramina at its ventral portion. The ventral margin of the ventral depression is formed by a thin, lateral ridge at the ventral margin of the jugal. This thin ridge lies on the jugal-ectopterygoid suture and makes this suture visible in lateral view. This suture extends posteriorly towards the junction of the infraorbital lateral ridge with the infratemporal ramus of the jugal. The posterior portion of the depression, ventral to the infraorbital ridge, opens into a thin, deep notch. This notch separates the laterally facing jugal-ectopterygoid suture and ridge from the remainder of the jugal. The slender postorbital bar arises from the posterior third of the total length of the jugal body. The jugal is overlapped by the postorbital laterally at about mid-height of the postorbital bar. The infratemporal process is less than half as deep as, but transversely thicker than, the infraorbital process and forms the ventral margin of the infratemporal fenestra. Anteriorly, the infratemporal ramus of the jugal has a subquadrangular cross section. This shape is a result of the presence of two longitudinal depressions on its outer surface. Dorsally, the bone is marked by the posterior extension of the dorsal longitudinal depression of the jugal infraorbital ramus, and ventrally the jugal is marked by a longitudinal shallow groove starting just behind the ectopterygoidjugal suture and ending at the midpoint of the infratemporal jugal ramus. Posteriorly, this cross section becomes cylindrical due to the absence of those depressions and slight increase of the diameter of the cross section.

An anterior suture for the nasal is preserved on the right premaxilla of LPRP/USP 0018. The suture indicates that the nasal would have entered the posterior midline of the external nares and likely formed at least a posterior division of the nares. The posteriormost portions of the nasals are preserved in LPRP/ USP 0019. The bones are thin, anteroposteriorly elongated elements and participate only in the dorsal portion of the skull. They are fused to each other along most of their extension and have a wide dorsal surface. At the level of the anterior orbital margin, the nasals are dorsally concave, forming a low surface with regard to the remaining portion of the skull roof. The preserved portions indicate a tendency for the lateral margins of the concavity to smoothly converge anteriorly. Sutures between the nasal, prefrontal, and frontal are obscured by heavy sculpting, but there is certainly no nasal-frontal contact posteriorly, at least externally. The posterolateral corner of the nasal concavity forms the upper portion of the stepped prefrontals, which bounds the large anterior palpebral facet.

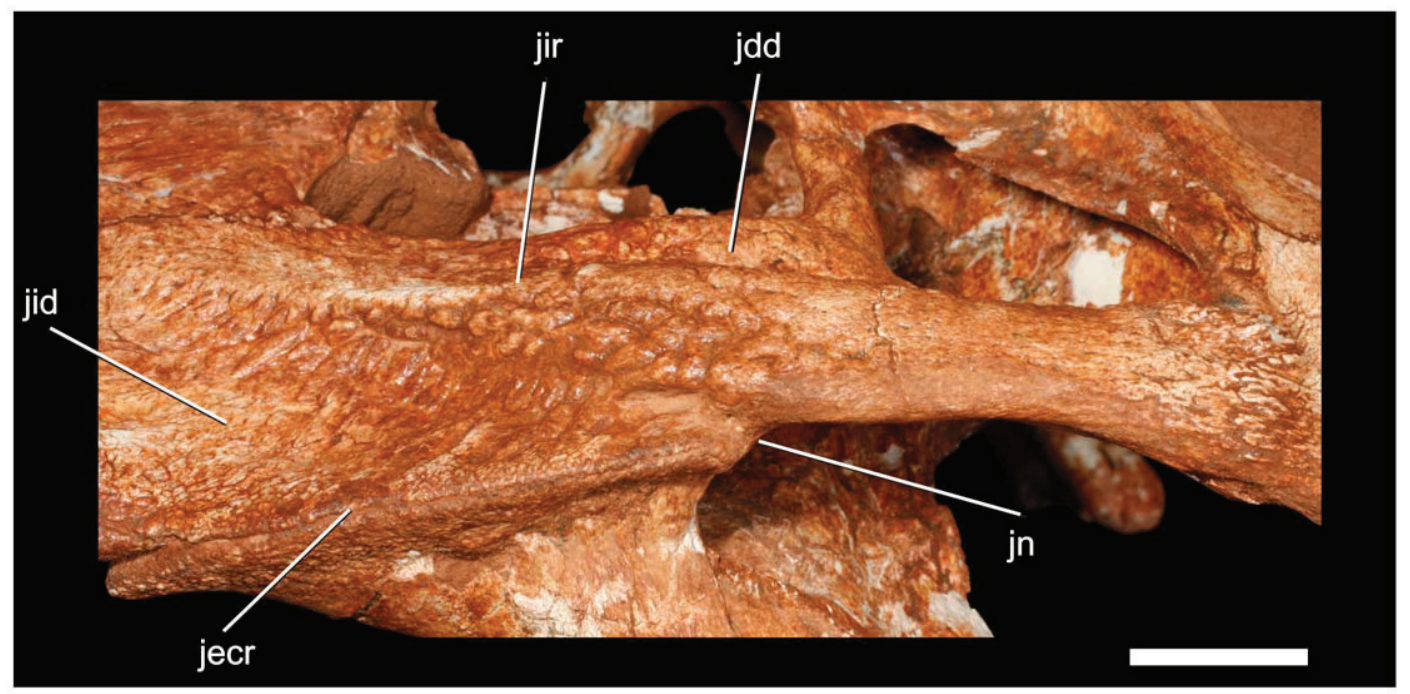

Figure 10. Details of the left cheek area of Pissarrachampsa sera (LPRP/USP 0018). Abbreviations: jecr, jugal-ectopterygoid ridged suture; jid, jugal infraorbital depression; jn, jugal notch. Scale bar equals $1 \mathrm{~cm}$. doi:10.1371/journal.pone.0021916.g010 


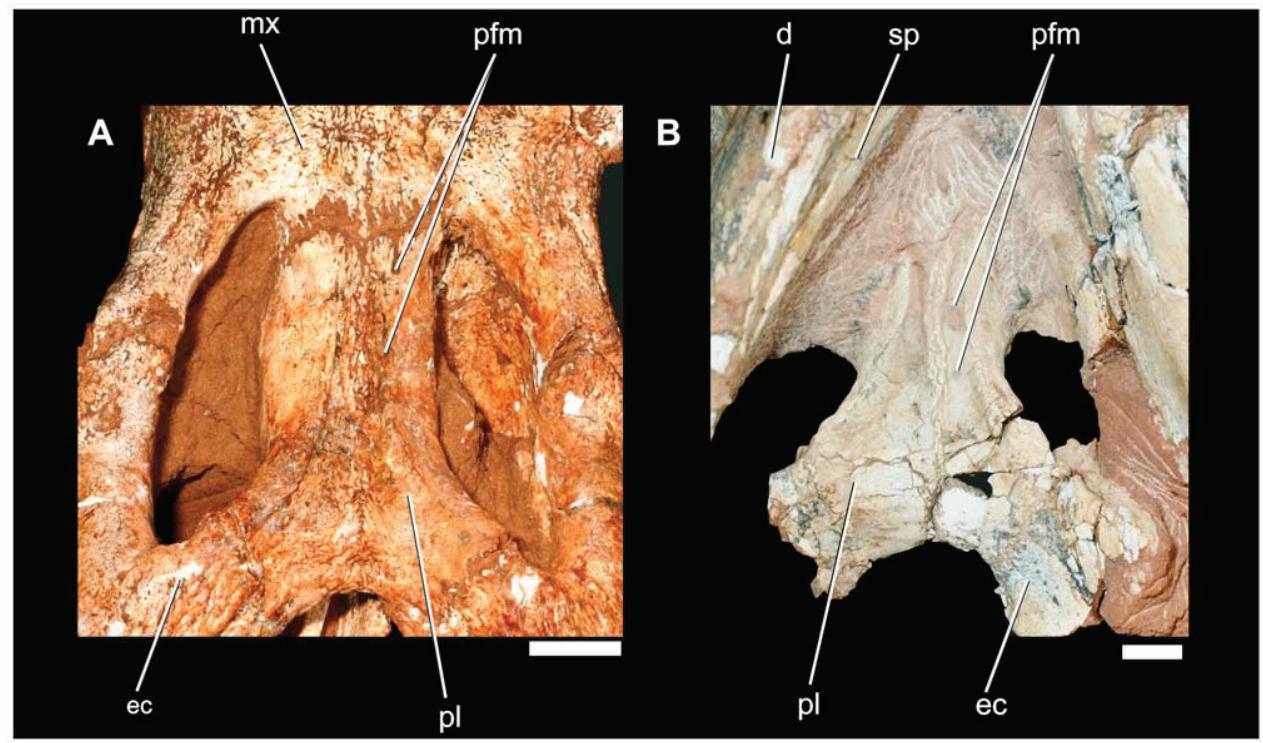

Figure 11. Details of the palatine ventral surface of Pissarrachampsa sera. A) LPRP/USP 0019; B) LPRP/USP 0018. Scale bar equals $1 \mathrm{~cm}$. doi:10.1371/journal.pone.0021916.g011

The rhomboidal prefrontals form the anteromedial margin and part of the anterior wall of the orbit. They have a large dorsal exposure, forming different surfaces on the medial and lateral halves that are separated by a step. The medial triangular surface is anteroposteriorly elongated and strongly ornamented with ridges and furrows. At the midlength of this portion, the major medial extension of the prefrontal contacts its counterpart and prevents contact between the frontal and nasal. The prefrontal contacts the frontal along a large, oblique suture. The lateral surface of the prefrontal is smaller and less ornamented. It has a broad articulation with the anterior palpebral bone. The right palpebral is missing, revealing the dorsal surface of the lateral portion of the prefrontal. This region is deeply excavated to form a broad articular facet that receives the anterior palpebral. The lateral margin of the prefrontal contacts the lacrimal along a nearly linear longitudinal suture. The prefrontal contributes to a nearly vertical orbital anterior wall. The

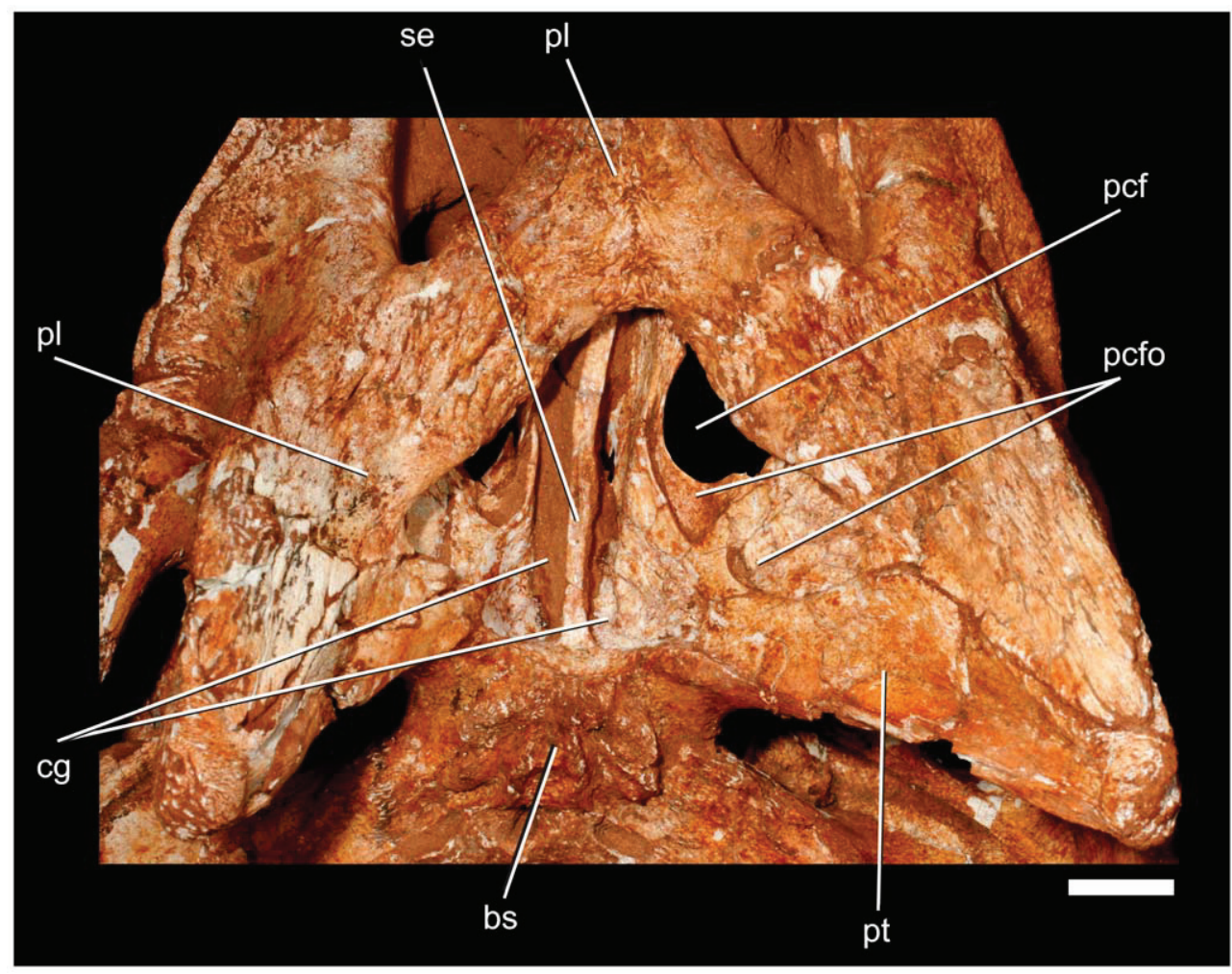

Figure 12. Details of the choanal region of Pissarrachampsa sera (LPRP/USP 0019). Scale bar equals $1 \mathrm{~cm}$. doi:10.1371/journal.pone.0021916.g012 


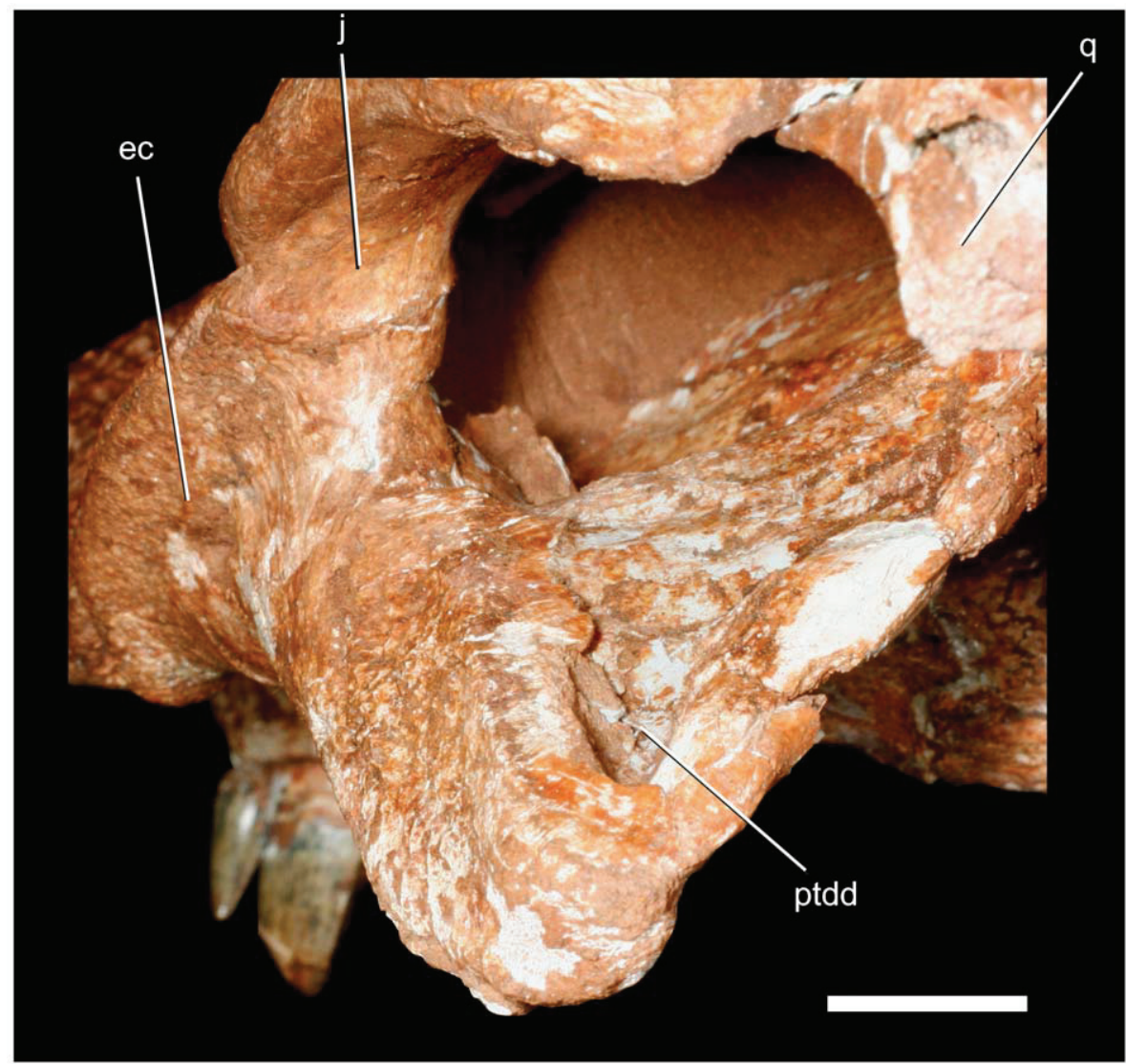

Figure 13. Details of the dorsal surface of the left pterygoid wing of Pissarrachampsa sera (LPRP/USP 0019). Image taken from posteroventral view. Scale bar equals $1 \mathrm{~cm}$. doi:10.1371/journal.pone.0021916.g013

prefrontal extends ventrally as a thin sheet of bone that forms the prefrontal pillar (Figure 9). The prefrontal pillar is transversely wide and spans from the midline to nearly the anterolateral margin of the orbit. The pillar is anteroposteriorly thin and posteriorly convex. Its anterior surface is not visible, but appears to have been concave and housed a pneumatic recess. The median portion of the prefrontal pillar extends to the pterygoid as a thin, flattened column arising from the ventromedial tip of the convex portion in the orbit. The column is ventromedially directed and expands distally in a semilunar shape oriented almost anteroposteriorly. The distal process barely contacts the pterygoid at its anterior tip, and no differentiated structure for its reception is observed on the palatine or pterygoid.

The lacrimal has two different surfaces on the skull. The dorsal portion is accessible on the right side contacting the prefrontal support for the palpebral via a linear, but jagged suture. This surface is almost unornamented and ventrally roofs the lateral surface of the lacrimal. The lateral surface of the lacrimal makes up much of the anterior margin and wall of the orbit. The ventral portion of the bone is firmly sutured to the dorsal region of the infraorbital process of jugal. This contact has a curved profile, which is continuous to the contact with the maxilla. The lacrimal, together with the curvature of the internal surface of prefrontal, also forms the lateral portion of orbital anterior wall. At the inflexion point between its dorsal and the lateral surfaces, the lacrimal is pierced by the foramen for the nasolacrimal duct.

The fused frontals have a complex outline. The anterior margins converge anteriorly, the lateral edge is concave about the orbital margin, and the posterior margin is convex, with the midregion bowing posteriorly. The anterior third is markedly ornamented and bears a smooth, midline depression (dorsal valley sensu [14]). The midline depression broadens posteriorly to form a dorsally concave surface over much of the remainder of the frontals. The lateral margins of the depression are slightly ornamented but are not raised to form an obvious ridge at the orbital rim. An unornamented sagittal crest, approximately $3 \mathrm{~mm}$ tall, occurs from the level of the posteriormost extension of prefrontal to near the frontal-parietal contact. The anterolateral portion of the frontal has a deep fossa for contact with the anterior palpebral. The frontal has a minor participation in the external supratemporal fenestra. The bone accompanies the thickened rim of the fenestra and forms a small anterior portion of supratemporal fossa. This part of the frontal is wedged between the postorbital and the parietal. Posteriorly, the frontal meets the parietal along an almost transverse suture, which extends between the medial thickened margins of the external supratemporal fenestrae. Posteroventrally, the frontal extensively contacts the dorsal portion of the laterosphenoids. Matrix obscures the ventral midline of the frontal and prevents access to the fine morphology of the cristae cranii and the passage for olfactory and optic traits. The posteroventrolateral corner of the frontal is underlapped by the postorbital but is entirely exposed laterally.

The fused parietals form the medial margin of the external and internal supratemporal fenestrae and fossae. This area is transversely constricted, and the medial margins of the external supratemporal fossae have distinct rims separated by a conspic- 


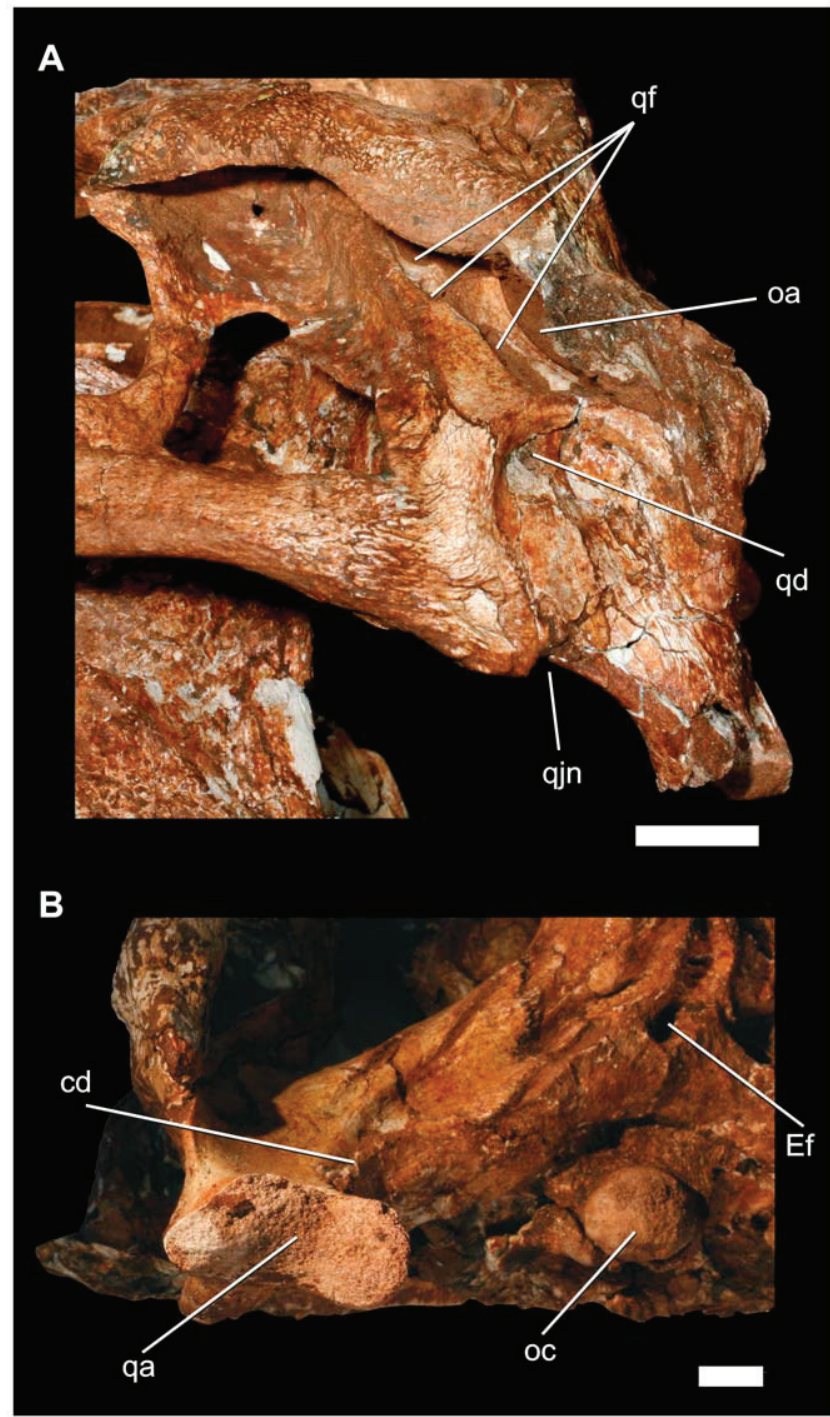

Figure 14. Details of the left posterolateral region of the cranium of Pissarrachampsa sera (LPRP/USP 0019). A) lateral view; B) ventral view. Abbreviations: qa, quadrate articulation; qjn, quadratojugal notch. Scale bars equals $1 \mathrm{~cm}$.

doi:10.1371/journal.pone.0021916.g014

uous sagittal groove. Anteriorly and posteriorly, the rims curve laterally and become continuous with the rims of the frontal, postorbital and supraoccipital. Within the supratemporal fossa, the parietal contacts the postorbital ventrally, preventing the frontal from bordering the internal supratemporal fenestra. The medial wall of the supratemporal fossa is formed by the parietal and is almost vertical and unornamented. The posteromedial part of this fossa is dorsoventrally deeper than other regions as a consequence of a gradual dorsal curvature of the parietal posteriorly. Posterolaterally, the parietal contacts the squamosal at the posterior portion of supratemporal fossa, at about the midpoint of the posterior margin of the internal supratemporal fenestra. A large oval temporo-orbital foramen is located on the suture between these two bones. This foramen faces dorsally and is confluent with a restricted groove in the parietal posterolateral portion. The posterior margin of that bone is firmly attached to the supraoccipital, forming an interdigitated suture along the parietal's entire transverse length.
The postorbital forms the anterolateral corner of the skull roof and possesses a descending process that forms the dorsal half of the postorbital bar. Dorsally, it also forms the posterolateral margin of the orbit as well as the anterolateral margin of the internal and external supratemporal fenestrae and fossae, separating the orbit from these other openings. The anterolateral corner of the postorbital bears a facet for the reception of the posterior palpebral. This facet is curved, and its lateral margin forms a short, sharp projection into the orbit. The auditory fossa is divided into two distinct portions. An anterior portion lies on the lateral surface of the postorbital and is separated from the posterior portion by a ridge at the quadratojugal-quadrate suture. This anterior portion extends to the posterior part of the postorbital bar, forming a posterolaterally oriented concavity at the back of the bar (Figure 14). A dorsolateral shelf, formed by the postorbital anteriorly and the squamosal posteriorly, overhangs the postorbital descending flange. This flange is a thin posteroventral extension of the postorbital body that overlies a small anterior portion of the quadratojugal. The slender postorbital bar is transversely oval in cross-section, and the postorbital bone reaches the mid-height of the bar, overlying the jugal ascending process laterally. Posterodorsally, the postorbital body is firmly attached to the squamosal at the level of the dorsal apex of the infratemporal fenestra.

The squamosal comprises the posterolateral corner of the skull roof. This element is slightly convex dorsally and has a distinctly sculptured dorsal surface. The ornamentations include a distinct pebbled surface at the border of external supratemporal fenestra. In lateral aspect, the posteroventral edge of the squamosal curves over the otic recess. This ventrally arched surface bears a shallow longitudinal sulcus, which was probably associated with attachment of muscles associated with an external earflap, as seen in extant and fossil crocodyliforms $[9,34,48]$. Anterodorsally, the squamosal is sutured to the postorbital nearly along the posterior third of the total length of the external supratemporal fenestra. The squamosal extends anteroventrally for a short distance, where it is overlapped by the descending flange of postorbital. Posteroventrally, the squamosal contacts the quadrate in front of the quadrate fenestrate area (Figure 14), but the posteroventral end of this contact is hidden by sediments and fractures. Posterodorsally, the squamosal deflects ventrally and extends posterolaterally from the skull roof, but the bone's lateralmost portion is not preserved. The posteroventral portion of the squamosal forms an inclined plate that extends posterolaterally, parallel to the dorsal edge of the paroccipital process. The anterolateral surface of this wall encloses the posterior margin of the external auditory meatus and the otic recess. The lateral margin of the dorsal portion of the squamosal extends over the auditory meatus. This arrangement creates a laterally opened auditory meatus, which is hidden in occipital view.

The quadratojugal forms nearly the entire posterior margin of the infratemporal fenestrae. The quadratojugal is unornamented, except for its anteroventral portion. The narrow anterodorsal ramus has a long sutural contact with the quadrate, which becomes distinctly ridged dorsal to its midlength. This ridged suture divides the otic recess in two different portions. The dorsal ramus of the quadratojugal is overlapped by the postorbital to exclude the quadrate and squamosal from the dorsal margin of the infratemporal fenestra. The infratemporal margin of the quadratojugal is smooth and lacks a spina quadratojugalis. A slight curvature is present at its dorsal midheight and may indicate the attachment of the musculus levator bulbi [9]. The posterior corner of the infratemporal fenestra is formed by the quadratojugal posterodorsally and jugal anteroventrally. The posteroventral portion of the quadratojugal extends a reduced process towards 


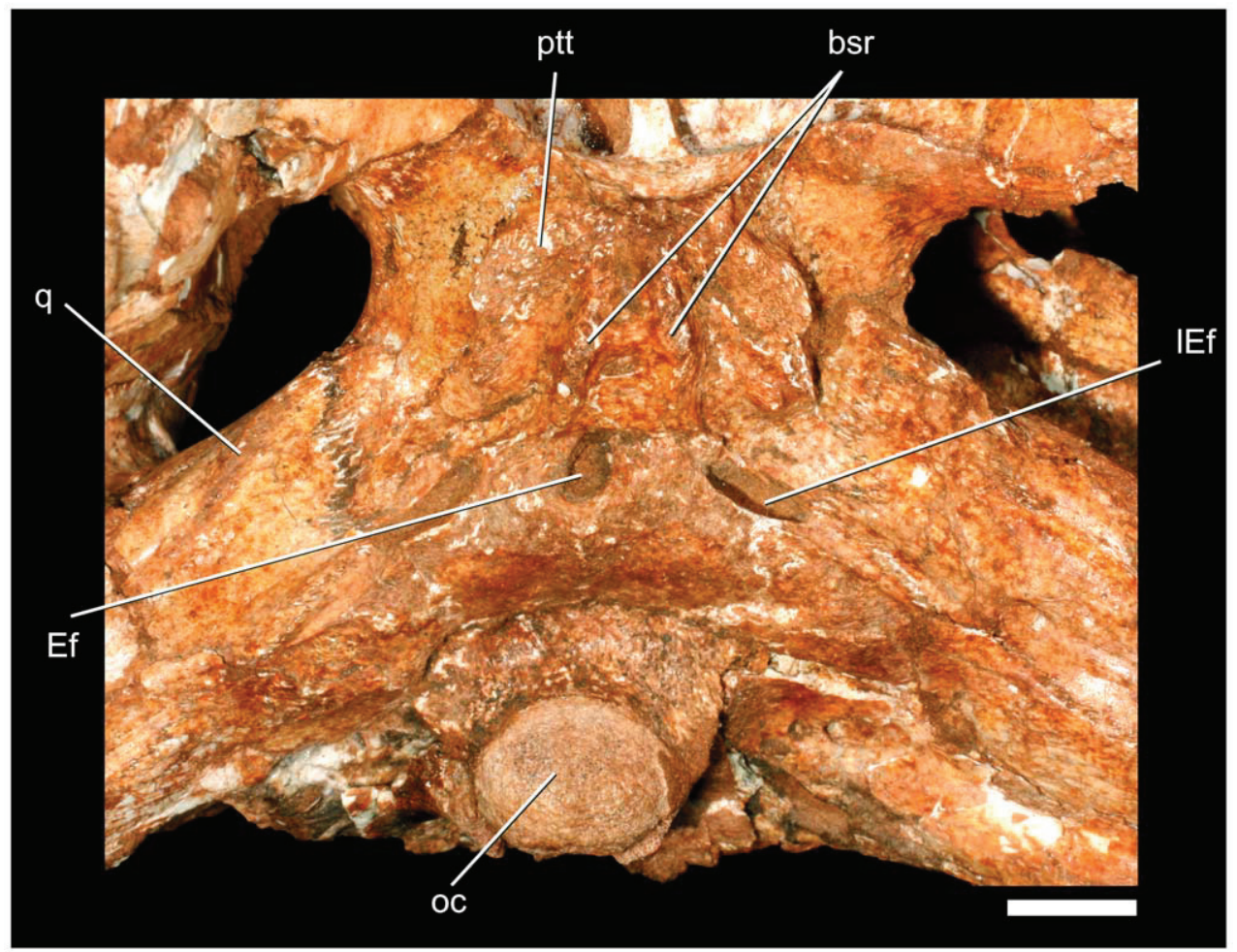

Figure 15. Details of the ventral portion of neurocranium of Pissarrachampsa sera (LPRP/USP 0019). Abbreviations: bsr, basisphenoid ridges; ptt, pterygoid tuberosity. Scale bar equals $1 \mathrm{~cm}$. doi:10.1371/journal.pone.0021916.g015

the mandibular condyle. In lateral view, this extension forms a small notch at the level of quadratojugal-quadrate contact (Figure 14). A lateral depression on the quadrate body extends onto the ventral portion of the quadratojugal-quadrate suture. The medial surface of the quadratojugal has long dorsal process, which prevents the contact between quadrate and postorbital, and reaches the ventral edge of the internal supratemporal fenestra.

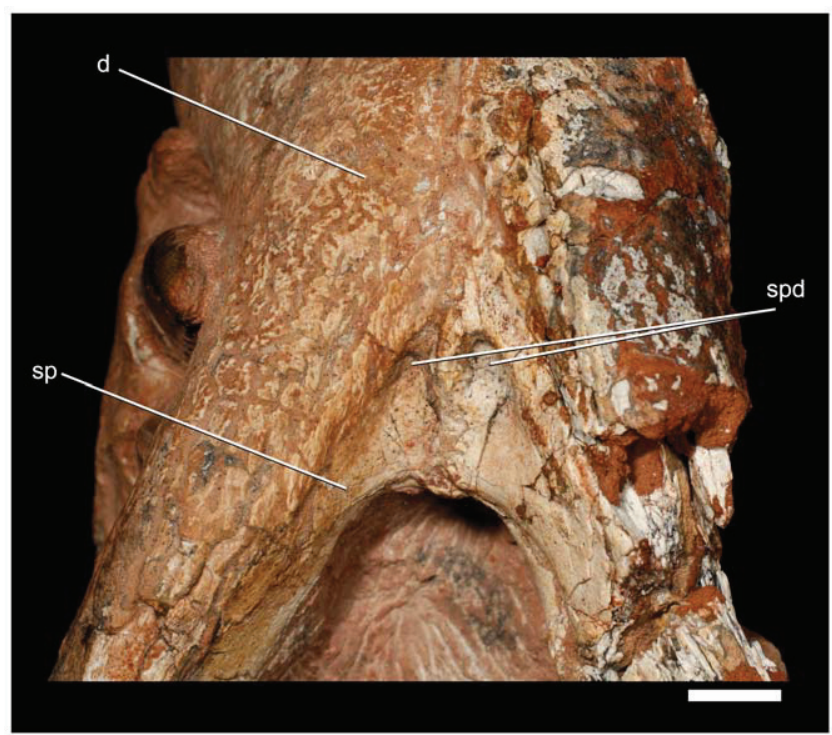

Figure 16. Detail of the ventral portion of symphysis of Pissarrachampsa sera (LPRP/USP 0018). Scale bar equals $1 \mathrm{~cm}$. doi:10.1371/journal.pone.0021916.g016
The large quadrate contributes to the jaw joint and is sutured to the lateral wall of the braincase. The bone is anterodorsally inclined so that its distal articular surface is situated posterior and ventral to the occipital condyle but laying at the same level of the tooth row. The articular surface is transversally oriented. The surface is medially constricted and divided into two condyles. The medial condyle is ventrally developed and faces ventrolaterally. The lateral condyle is more dorsally positioned and posteroventrally oriented. This arrangement forms a sharp angle between the articular surfaces of each condyle. A dorsal extension of the intercondylar constriction is developed over the medial condyle. This extension is associated with a low crest and shallow groove that extends from the condyle to the contact between the quadrate and the paroccipital process near the cranio-quadrate passage. A well developed foramen aërum is situated on the posterior surface of the quadrate, near the dorsal margin of the condylar constriction (Figure 5), and opens into the shallow groove extending from the constriction.

The large otic aperture is laterally facing and has an elongated elliptical outline that is obliquely oriented in relation to the skull roof. The anterior and ventral margins of the otic foramen are entirely placed within the quadrate, and the dorsal and posterior margins are not visible. Four other apertures are present within a recessed fenestrate area of quadrate. These apertures border the ventral and anterior margins of the otic foramen and were probably external apertures of pneumatic quadrate diverticula. The posteriormost aperture is located ventral to the otic foramen, two apertures are anterodorsal to this ventral aperture, and the fourth aperture is positioned anterodorsally, in front of the otic foramen. The form and size of the apertures vary significantly; the posterior one has an elliptical shape and is the largest, i.e., about two thirds of the otic foramen size (20 $\mathrm{mm}$ in diameter). The other apertures are rounded and smaller, with the two ventral ones 
Table 1. Selected measurements (in $\mathrm{cm}$ ) for the skull LPRP/USP 0019.

\begin{tabular}{lll}
\hline LPRP/USP 0019 & 26.36 \\
\hline Preserved basal skull length (from tip of snout to occipital condyle along midline) & 25.06 \\
Preserved length of skull (from posterior end of skull table to tip of snout, on midline) & 11.31 \\
Preserved length of snout (from anterior end of orbit to tip of snout) & 17.22 \\
Greatest transverse width of skull (across quadratojugals) & 3.6 \\
Least transverse interorbital distance & 4.78 \\
Transverse width of skull at level of anterior ends of orbits \\
$\begin{array}{l}\text { Transverse width of skull at level of postorbital bars } \\
\text { Transverse width of skull table posteriorly }\end{array}$ \\
\hline
\end{tabular}

doi:10.1371/journal.pone.0021916.t001

about $5 \mathrm{~mm}$ in diameter and the anterodorsal one about $9 \mathrm{~mm}$ in diameter. The orientation of the apertures is also variable. The ventral aperture faces posterodorsally, the anterodorsal aperture opens posteroventrally, and the two ventral apertures face more posteriorly. Ventromedially, the quadrate extends along the anteroventral edge of the paroccipital process to contact the basioccipital, basisphenoid, and pterygoid. The midlength portion of the contact between quadrate and basioccipital forms a low crest that is continuous to another crest extending from the medial margin of the medial quadrate condyle. This crest is similar to crest ' $D$ ' of [40]. Anteriorly, the quadrate contact against the braincase forms much of the ventral and posterior margins of the large trigeminal foramen. Anteroventrally, the quadrate is attached to the quadrate ramus of the pterygoid and to the posterolateral portion of the basisphenoid. Dorsomedially, the quadrate extends into the internal supratemporal chamber, contacting the ventral edges of the parietal and squamosal in the posterior wall of the internal supratemporal fenestra. The quadrate is firmly attached to the laterosphenoids anteriorly along a nearly vertical suture. Two low parallel crests occur lateral to the quadrate-pterygoid contact. The anterior crest is well defined and lies on the margin of the ventral and anterior portions of the quadrate ('crest B' of [40]). The other is less conspicuous and posteriorly adjacent. A large sigmoidal muscle attachment crest lies just posterior to the medial suture between quadrate and quadratojugal and probably corresponds to 'crest A' $[39,40]$ in extant crocodylians. This was related to the origin of the musculus adductor mandibulae posterior $[9,39,40]$ or musculus adductor mandibulae externus superficialis [49].

Two palpebral bones are preserved in the left side of LPRP/ USP 0019. They are thick elements with strongly ornamented dorsal surfaces. The anterior bone is hooked-shaped and articulates onto the prefrontal and lacrimal lateral projections, fitting on the step between those structures and the skull roof. Its posteromedial portion also fits in a small facet anterior on the orbital margin of the frontal. The anterior palpebral is dorsally convex, following the dorsal curvature of the skull at this level. Its posterolateral extension contacts the posterior palpebral about the level of the mid length of orbit. The posterior palpebral is small, well ornamented, and has a dorsally convex transverse profile. It has a subquadrate outline, articulates into a postorbital facet for this bone and contacts the anterior palpebral by means of a short spur of its anterolateral corner.

The palatine palatal shelves of LPRP/USP 0019 are tightly sutured into a stout element that forms nearly the entire posterior half of the secondary bony palate along most of its length (Figure 11). The palatine bar has a transversely reduced, ventrally flat, and extensively sculpted surface. Dorsally, the palatine becomes cylindrical with a nearly entirely unsculptured surface. The palatine-maxilla contact forms a transverse, interdigitaded suture. The suture traverses about one third of the palatal surface and is located just posterior to the anterior margin of the suborbital fenestrae. This arrangement prevents the palatine from reaching the lateral border of the suborbital fenestra near the tooth row. The midline suture is nearly straight along its entire length when viewed ventrally. The suture is ridged along its midlength and is flanked by a parasagittal groove in each side. The grooves become confluent posterior to the ridge. This confluence, combined with raised rims at the medial margins of the suborbital fenestra, forms a wide median depression on the posterior half of palatine palatal surface. A row of foramina dots the medial edge of the raised rim of the suborbital fenestra (Figure 11). The palatine extends a stout posterolateral process that is firmly attached to the anteromedial process of the ectopterygoid. This posterolateral processes bounds the anterior apex of the wide choanal aperture. The anteriormost portion of the palatal contact between the palatine and pterygoid is located anterodorsal to the anterior border of the choanal opening. The posterodorsal portion of the palatine is not accessible. Hhowever, it contacts a thin sheet of bone of the pterygoid (described below). This suture originates at the anterior tip of the dorsal surface of the parachoanal fenestra (see below) and extends perpendicularly to the sagittal plane for a

Table 2. Selected measurements (in $\mathrm{cm}$ ) for the skull LPRP/USP 0018.

\begin{tabular}{ll}
\hline LPRP/USP $\mathbf{0 0 1 8}$ \\
\hline Preserved length of skull (from posterior end of preserved palatines to anterior tip of snout along midline) \\
\hline Preserved length of snout (from posterior end of preserved maxilla to anterior tip of snout along midline) \\
\hline doi:10.1371/journal.pone.0021916.t002
\end{tabular}


short distance, then turning to an anterodorsal inclination in relation to the main palatal plane. Posterolaterally, the palatine sutures to the ectopterygoid at the anterior quarter of the lateral edge of the parachoanal fenestra. This dorsal portion of palatine is overlapped dorsally by the pterygoid and does not contact the prefrontal pillar. Together with the dorsal portion of the pterygoid, the palatine forms an inclined plane that roofs the posterior portion of narial passage.

The fused pterygoids have three distinct regions: a compact body attached to the anteroventral and lateral portions of the neurocranium, a pair of posteroventrally projecting flanges (pterygoid wings), and a broad, transversely concave and posteroventrally inclined sheet of bone bearing the choanal groove and parachoanal structures (choanal septum, fenestra and fossa, Figure 12). The anterior ramus of the pterygoid extends far anteriorly to the prefrontal pillar contact and is broadly exposed dorsal to the palatine when viewed through the orbit. Posterior to the contact with the prefrontal pillar, the pterygoids form a thin, sagittal septum that extends a short distance dorsally as an interorbital septum and continues posteriorly to suture to the parasphenoid. The pterygoid-parasphenoid dorsal margin is slightly broken, but appears to have been a single, continuous margin. There is no clear separation between the pterygoid and parasphenoid. A subtriangular fenestra occurs in the anterolateral portion of the pterygoid. We term this the parachoanal fenestra, because of its proximity to the choana. Dorsally, the anterior quarter of this fenestra is bounded by the palatine, the posterolateral half is bounded by the ectopterygoid, and the remainder by the pterygoid. Ventrally, this configuration remains the same, but the robust palatine bar, composed of the posterolateral ramus of the palatine and anteromedial ramus of the ectopterygoid, borders it anteriorly.

A large choanal depression is bounded anteriorly by the palatines, anterolaterally by the ectopterygoids, and the remainder entirely by the pterygoids. This depression houses a number of parachoanal structures and an elongated, divided choanal groove (Figure 12). The palatine-ectopterygoid margin of the choanae is ventrally located in relation to the remaining portion, so that the depression opens posteroventrally. The choanal septum, formed entirely by the pterygoids, is confluent with the posterior surface of the choana and is well recessed below the margin of the choanal depression. The ventral edge of the septum is subcolumnar in cross-section, with a distinctly flattened ventral surface. There is no trace of a midline ridge on the septum. The dorsal portion of the septum appears to be a thin sheet of bone. The posterior, medial, and lateral margins of the parachoanal fenestra extend onto the ventral surface of the pterygoids, as a broad fossa named the parachoanal fossa. This fossa is subdivided into medial and lateral subfossae by a smooth, low ridge. The left ridge only partly divides the medial and lateral portions of the parachoanal fossa, but the right ridge divides these portions nearly to the posterolateral margin of the parachoanal fenestra. The parachoanal fossae probably housed pneumatic chambers related to the choana and may have been used for vocalization. The medial parachoanal subfossa excavates a short distance into the pterygoid body. The lateral parachoanal subfossa excavates into the pterygoid body posteromedially and expands anterolaterally onto the ectopterygoid-pterygoid suture. The fossa expands anteriorly to excavate a chamber within the ectopterygoid body. At the lateral corner of this fossa, the ectopterygoid-pterygoid suture has a large, robust butt joint that extends to a nearly linear suture towards the tip of the pterygoid wing.

The pterygoid wings are overlapped by the ectopterygoids ventrally, which nearly reach the ventral tip of the pterygoid wing. The right pterygoid wing diverges at $80^{\circ}$ and the left wing diverges at about $60^{\circ}$ relative to the sagittal plane of the skull, and both wings diverge about $45^{\circ}$ from the palatal plane, forming the ventralmost extension of the skull. The sheet of bone forming the parachoanal structures is thin and dorsally separated from the rest of pterygoid and ectopterygoid by a step, except along its posterolateral portion, where it is confluent with the pterygoid wing surface. This structure follows the ventral inclination of the pterygoid wings and culminates dorsally in the dorsal roof of the choanal aperture.

Behind the choanal opening, the pterygoid does not extend much ventrally, but forms two laterally displaced tuberosities confluent to the anterior portion of the basisphenoid. This configuration does not form a posterior vertical wall and clearly separates the pterygoid from the median Eustachian fossa anterior extension. Additionally, in the absence of a vertical posterior pterygoid wall, this area is not continuous to 'crest B' [39]. The contact between the pterygoid and quadrate extends dorsally along the braincase in a course that passes posterodorsally and then turns anterodorsally. The pterygoid extends up to the contact between the laterosphenoid and quadrate below the trigeminal foramen. From this point onward, the contact between the pterygoid and laterosphenoid extends anteriorly to the contact between the pterygoids. The base of this contact can be seen anteriorly, forming a sagittal crest in the interorbital space.

The posterodorsal process of the pterygoid extends until it contacts the quadrate ventromedial process at the level of the basioccipital lateral extension. The posterodorsal process is connected to the pterygoid wing via a curved blunt ridge. The medial portion of the pterygoid wing is very thin but becomes thicker laterodistally and has a pitted surface that presumably would have been covered by a cartilaginous cap in life. The thickness of the lateral and distal portions, combined with the ridged posteromedial dorsal edge, delimits a well marked depression that occupies mostly of the dorsal surface of the pterygoid wing (Figure 13).

The ectopterygoid is robust, caps the ventral edge of the pterygoid wing, and forms most of the posterior ventrolateral portion of the palate. On the pterygoid wings, the ectopterygoid descends to a point just short of the distal tip, and its ventral surface is ornamented with parallel longitudinal ridges. The body of the ectopterygoid has an elongate elliptical cross-section, with its long axis directed anteromedially. The ectopterygoid extends a small distance posteriorly onto the base of the pterygoid wing but does not reach the postorbital bar. The posterolateral contact with the jugal forms a right angle and is slightly raised from the ventral surface of the jugal. Foramina pierce the lateral surface of the ectopterygoid near the jugal contact. The right ectopterygoid bears five foramina of different sizes in this area, with the anterior one three times the size of any other, and the left ectopterygoid has only a single, large foramen. Anteriorly, the ectopterygoid has two small rami. The anterolateral ramus fits into the maxillary posterior process at the level of the midpoint of the suborbital fenestra. The stout anteromedial process overlaps the pterygoid ventrally and contacts the palatine posterolateral process to border the choanal opening anterolaterally. The dorsal surface of the ectopterygoid body is horizontally placed and contacts the jugal along most of its extension. Medial to the jugal contact, the ectopterygoid is deeply concave, nearly forming a ventrally facing plane until the origin of the pterygoid wing. The ectopterygoid-jugal suture extends essentially along the corner between the lateral and ventral surfaces of the skull and is distinctly ridged. This ectopterygoid configuration makes it border the lateral posterior half and the posterior tip of the suborbital fenestra. Dorsally, the ectopterygoid sutures to the palatine posterolateral process, perpendicular to the medial and lateral edges of the palatine bar. This suture extends medially to border the posterolateral half of the parachoanal fenestra. 
Posteriorly, the ectopterygoid contacts the pterygoid dorsally to the base of the pterygoid wing, forming an anteromedially directed suture that reaches the parachoanal fenestra.

The unpaired supraoccipital is visible on the dorsal surface of the skull as a thin slip articulated to the posterior margin of the parietal. This element tapers laterally until its inflexion to the occipital surface at the level of the medial edge of the temporoorbital foramen. This dorsal exposure possesses a median depression confluent with the sagittal groove on the intertemporal bar. From its inflexion point, the supraoccipital is attached to the squamosal via a dorsally arched suture that contacts the otoccipital ventrally. In occipital view, the supraoccipital is wider than tall and forms a slightly posteriorly concave vertical wall. This surface bears a low median ridge restricted to the dorsal half of the bone, which is flanked on both sides by a depression that probably served for the insertion of nuchal ligaments. Additionally, the supraoccipital bears a series of radiating ridges which tend to converge ventrally towards the foramen magnum, forming a broad, triangular, ventral extension of the supraoccipital. The lateral articulation of this ventral extension is nearly linear. Ventrally, the supraoccipital is excluded from the dorsal margin of the foramen magnum by a broad median contact between the otoccipitals.

The laterosphenoid is a compact bone firmly attached to the anterodorsal portion of the braincase. It has a slender capitate process that diverges laterally from the basisphenoid body, reaching the postorbital. Its lateralmost portion forms a condyle that fits into a medial notch of the postorbital. The tiny tensor crest (probably related to musculus levator bulbi dorsalis, [43]) is distinguished in the median portion of the capitate process. The anteromedial extension of the capitate process extends onto the frontal. Posterior to the postorbital, the laterosphenoid probably contacted the parietal below the internal supratemporal fenestra. Posteriorly, the laterosphenoid is attached to the anterior portion of the quadrate just posterior to the foramen for passage of nervus trigeminus $(\mathrm{V})$. The laterosphenoid forms the anterior and dorsal, as well as much of the posterior margins of the trigeminal foramen by means of a blunt ventral extension of the capitate process that is slight bifurcated at the level of this foramen. Anterolateral to this ventral extension, there is a rounded depression which probably enclosed the ophthalmic (V1) and oculomotor (fIII) foramina [43]. The well developed laterosphenoid ventral ridge probably overlaps the prootic laterally, but the suture is not visible.

The exoccipital and opisthotic are indistinguishably fused into a single otoccipital. The otoccipitals meet medially and form a bony shelf roofing the foramen magnum, as well as the lateral portion of this opening. Each element forms a broadly convex posterior surface on the occiput. That surface is dorsoventrally thin dorsal to the foramen magnum, but expands laterally, which combined with the dorsal extension of the depression on the medial condyle of the quadrate, forms a broad concave region distally and ventrally on the skull occipital plane. The otoccipital also contributes to the dorsolateral corner of the occipital condyle. The best preserved left side, near the foramen magnum, bears a single, small, posterolaterally facing hypoglossal foramen. Lateral to the hypoglossal foramen there is a larger, undivided, and posterolaterally facing vagal foramen, which would have provided route for nervi glossopharyngeus and vagus (IX-X). A small cranio-quadrate passage occurs ventral to the paroccipital process and medial to the triple contact between the squamosal, quadrate, and paroccipital process. This passage lies in the dorsal portion of a well marked medial depressed area of the occipital plane. The passage is partially covered by sediment, but extends medially into a cranio-quadrate canal running along the otoccipital-quadrate contact. The posterior surface of the distal end of the paroccipital process closes the ventral portion of the auditory meatus and bears distinct striations along its distal margin. These are possibly related to insertions of the musculus longissimus capitis superficialis and musculus iliocostalis capitis [44].

The basioccipital forms most of the peg-like occipital condyle, the external surface of which is not well preserved. Yet, it is clear that the basioccipital forms only the medial portion of the floor of the foramen magnum and cranial cavity. The basioccipital's posterior surface is slightly inclined and faces posteroventrally. The posteroventrally curved condylar neck is ornamented with tiny shallow pits and strongly deflected from the posteroventral surface of the basioccipital. The posteroventral surface of that bone slopes anteroventrally, forming an angle of approximately $30^{\circ}$ relative to the skull roof plane. A short, median crest occurs from the base of the condylar neck to the opening of the median Eustachian tube (foramen intertympanicum), which is situated within a deep depression on the suture between the basioccipital and basisphenoid. The openings of the lateral Eustachian canals are lateral and slightly posterior to the median opening. The lateral openings are much larger than the medial foramen and have elongate, elliptical outlines (Figure 15). These openings lack a portion of their anterior walls so that the foramina open anterolaterally. The ventrolateral portions of the basioccipital are concealed by the basisphenoid and quadrates.

The basisphenoid and parasphenoid appear to be indistinguishably fused. The basisphenoid is largely exposed in ventral aspect and is inclined anteroventrally, following the slope of the basioccipital. The basisphenoid is bounded by the pterygoids anteriorly and basioccipital posteriorly, and the element's lateral projections contact the pterygoid ramus of the quadrate. The ventral surface of the basisphenoid has two short, but well defined, crests oriented parasagittally on the lateral margins of the median Eustachian tube (Figure 15). These crests delimit a deep groove between them, which is divided anteriorly by a transverse, less marked crest. Laterally, the basisphenoid forms a dorsal level which is separated from the ventral surface of quadrate and pterygoid by a well-developed step. As a consequence, the basisphenoid central region projects ventrally. The anterior contact with the pterygoid occurs posteriorly to the anterior rugose tuberosity that forms the ventralmost portion of the posterior wall of the choanae. The great ventral development of the basisphenoid and the occurrence of distinct ridges and tuberosities are possibly related to the insertions of the musculus longissimus capitis profundus and musculus rectus capitis anticus major, which are attached to the basal tubera in extant crocodyliforms [44].

\section{Mandible}

Both partial mandibular rami of LPRP/USP 0018 are preserved and comprise much of the dentaries and the anterior part of the splenials (Figure 16). The number of dentary teeth is not determinable due to the complete overbite of the upper dentition. The mandibular symphysis is well developed and extends posteriorly until the level of the third maxillary tooth. The splenials form nearly the entire length of the strictly ventral surface of the symphysis. Anterior to that, the mandible is anterodorsally directed, at an angle of about $45^{\circ}$, and the symphysis is formed solely by the dentaries. In ventral view, the dentary-splenial suture tapers anteriorly, wedging the dentaries at the level of the divergence of the mandibular rami (Figure 16). Posteriorly, that suture extends subparallel to the medial edge of the mandible, but becomes gradually closer to that medial edge, and then turns onto the medial surface. This inflexion point occurs posterior to the symphysis, where the splenial covers the medial surface of dentary, probably bordering the tooth row medially. Behind the posterior end of the 
symphyseal facet, the splenial has a large slot-like foramen intramandibularis oralis for the mandibular ramus of nervus trigeminus (V3). The posterior margin of the symphysis is excavated by depressions, forming two distinct steps. The anterior step is at the level of the dentary-splenial suture, forming a narrow dorsally displaced surface. This depressed area is further dorsally displaced by a second, posterior, and more marked depression at splenial ventral surface. The area posterior to the anterior depression includes the ridged medial suture of the splenials, which more posteriorly forms a peg at the posterior surface of the symphysis. This depressed area is marked at its median portion by a pair of rounded distinct fossae that face posteroventrally. The outer surface is markedly sculptured at the anterior and ventral portions of the dentary. In addition, the splenial ventral surface is sculptured at the area between the ventral symphyseal depressions. The dentary is dorsoventrally deep along its entire preserved portion, especially at the level of the dentary caniniform tooth. At this point, the dentary also bulges laterally. The combination of the upturned dentary tip, the dorsoventrally deeper anterior portion, and the bulged lateral portion of the dentary, makes the anterior portion of mandible very robust. The second and third premaxillary teeth occlude onto slight notches on the mesial and lateral surfaces, respectively. The first alveolus is slightly procumbent, and the tooth occludes into a depression on the anterior portion of the premaxillary palatal shelf.

\section{Dentition}

Pissarrachampsa sera has a reduced number of teeth, with only three in each premaxilla and four in each maxilla. The complete dentary tooth row is not preserved, but we estimate that it had more than 8 teeth. The premaxillary and anterior dentary teeth posses round cross-sections and are slightly posteriorly curved, lacking well-defined carinae. The maxillary and posterior dentary tooth crowns, on the other side, point backwards, and are strongly laterally compressed, with distinct, finely serrated mesial and distal cutting edges (ziphodont morphology, sensu [45]). The sizes of the teeth vary greatly; measurements are given in Table 3 and 4 . The first and second premaxillary teeth are of similar size, whereas the third is hypertrophied, but all of them overhang the dentary mesially and laterally. The preserved external surface indicates that a deep occlusal pit between, as well as distal to, the first and second premaxillary alveoli received a dentary tooth (probably $\mathrm{d} \mathrm{l}$ ). When the mouth is closed, the maxillary teeth are placed in a lateral concavity of the dentary, so that $\mathrm{ml}$ is slightly laterally displaced by the bulge of the anterior portion of that bone, which supports the caniniform tooth (d4). M2 is located in the ventralmost extension of the maxillary alveolar margin, so that its ventral tip is at the same level of the mandibular ventral edge.

The serrated mesial and distal cutting edges of the teeth are better preserved in LPRP/0019. The serrations are placed along most of the crown mesial and distal margins (except at the tip, where they are probably worn off) and are formed by true denticles juxtaposed one another. In this sense, Pissarrachampsa has true ziphodont teeth sensu [45]. The morphology of the denticles, as well their size, does not vary significantly along the carinae. Each denticle is represented by a trapezoidal element with a sharp outer margin. As a consequence of this pattern, the density of denticles is almost the same along most of the carinae (3-4 denticles/mm).

\section{Results}

\section{General comparisons among Baurusuchidae}

Pissarrachampsa sera is obviously related to Baurusuchidae. The group has long been diagnosed in precladistic and cladistic studies by the presence of a laterally compressed rostrum, absence of antorbital fenestrae, notch in rostrum for the reception of dentary caniniform tooth, approximation of prefrontals, well developed palatine bar, ectopterygoids forming the choanal border, quadratojugal extending dorsally as broad sheet contacting most of postorbital portion of postorbital bar, vertical quadrate, reduced number of teeth, hypertrophied maxillary tooth and ziphodont dentition [1,18,19,21,45,50-52]. All these traits are present in Pissarrachampsa, but within clade relationships have never been discussed. Although baurusuchids are easily distinguished from the other Mesozoic crocodyliforms, the clade posseses a relatively high degree of ingroup morphological variation that is often overlooked. We present a detailed diagnosis for each putative South American baurusuchid in Text S1 in order to determine a unique suite of characters for each species, justifying a broader phylogenetic analysis of baurusuchids. These diagnoses validate the discrete taxonomic assignments of these taxa and may aid in future revisions of other possible baurusuchids. Before discussing specific characters, we provide additional comparisons within the group. These general comparisons are difficult to quantify and/or qualify as discrete characters and have not yet been used in phylogenetic analyses.

One of the most notable variations within the group is size. Cynodontosuchus is the smallest baurusuchid (but see following sections) with a preserved rostrum of less than $100 \mathrm{~mm}$. In contrast, Stratiotosuchus has a skull length of approximately $470 \mathrm{~mm}$. The relative proportions between different skull regions

Table 3. Maximum labiolingual and mesiodistal diameters, and apicobasal length $(\mathrm{in} \mathrm{cm}$ ) of premaxillary maxillary (m) tooth crowns of LPRP/USP 0019.

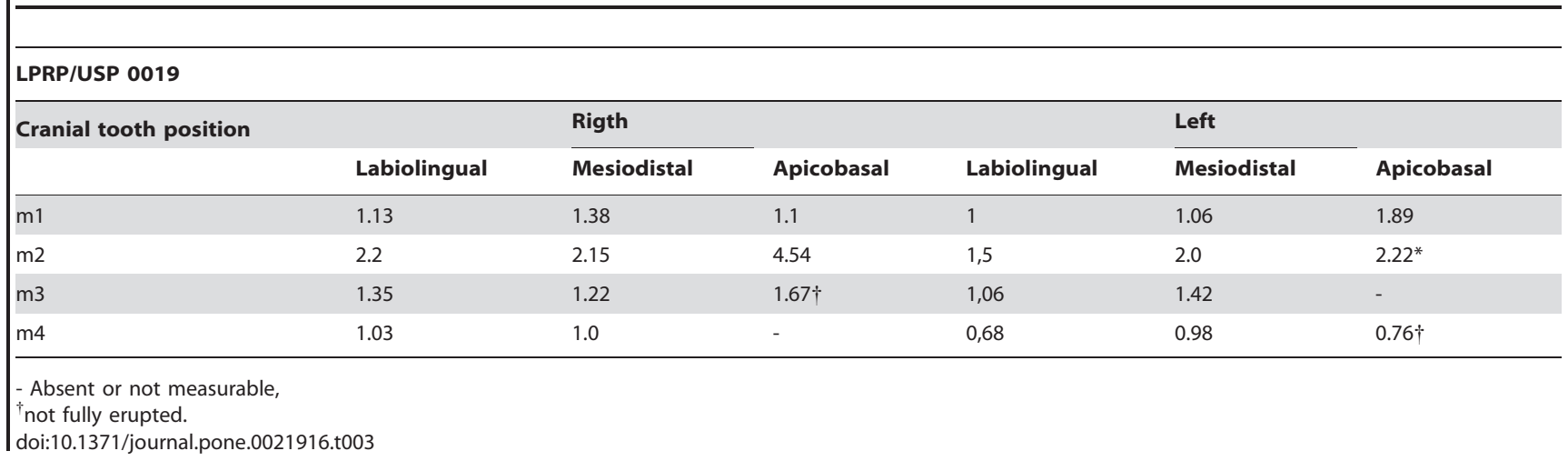


Table 4. Maximum labiolingual and mesiodistal diameters, and apicobasal length (in $\mathrm{cm}$ ) of premaxillary (pm), maxillary (m) and dentary (d) tooth crowns of LPRP/USP 0018.

\begin{tabular}{|c|c|c|c|}
\hline \multicolumn{4}{|l|}{ LPRP/USP 0018} \\
\hline \multirow{2}{*}{ Cranial tooth position } & \multirow[b]{2}{*}{ Labiolingual } & \multirow{2}{*}{$\frac{\text { Right }}{\text { Mesiodistal }}$} & \multirow[b]{2}{*}{ Apicobasa } \\
\hline & & & \\
\hline pm1 & $0.55^{*}$ & 0.8 & $0.99^{*}$ \\
\hline pm2 & 0.63 & 0.8 & 1.42 \\
\hline pm3 & $1.24^{*}$ & $1.22^{*}$ & $0.89^{*}$ \\
\hline m1 & $0.55^{*}$ & $0.74^{*}$ & $1.59 *$ \\
\hline $\mathrm{m} 2$ & $0.97^{*}$ & 1.46 & 3.88 \\
\hline m3 & - & $1.03^{*}$ & $1.32^{*}$ \\
\hline m4 & - & $0.61 *$ & $1.16^{*}$ \\
\hline d1 & 0.66 & - & 1.72 \\
\hline d4 & $0.9^{*}$ & 1.7 & $2.38^{*}$ \\
\hline
\end{tabular}

also vary. A most obvious example is the variation of rostral length. In Pissarrachampsa, the rostrum, measured from the anterior edge of the orbit to the tip of the premaxilla is estimated to be only $42 \%$ of the total skull length and falls into the "short rostrum category" of [38]. The rostra of Stratiotosuchus and Baurusuchus salgadoensis are nearly $65 \%$ of the skull length and classified as "normal", close to "long" rostra. The robustness of the skull bones also varies, even though this trait is hard to quantify. Pissarrachampsa, Wargosuchus, Baurusuchus pachecoi, and Cynodontosuchus have more lightly built skulls compared to Stratiotosuchus and Baurusuchus salgadoensis, which have more massive skulls.

Orientation of the external nares, orbits, choanae, and distal quadrates also vary slightly within the group. This variation is not marked enough to warrant discrete character state coding, but may be useful in future analyses. The external nares of most baurusuchids open directly anteriorly. Those of Stratiotosuchus open in a more anterodorsal direction, with the dorsal roofing bones of the nares slightly retracted posteriorly.

The otic region is highly variable among baurusuchids. Stratiotosuchus, Baurusuchus salgadoensis, and B. alberto $i$ have an enlarged otic recess and the descending flange of the squamosal does not cover much the otic aperture. In contrast, this flange partially hides the otic recess and the otic aperture in Pissarrachampsa and Baurusuchus pachecoi. The lateral depression on the quadrate varies from the anteroposteriorly broad depression in Pissarrachampsa, which expands onto the quadratojugal-jugal suture, to the dorsoventrally expanded but anteroposteriorly restricted depression in Stratiotosuchus, to the subcircular depression in other baurusuchids. The anterior support for palpebrals varies from the laterally stepped articulation with the prefrontal in Pissarrachampsa, Wargosuchus and Stratiotosuchus to an abbreviated step in Baurusuchus pachecoi and Baurusuchus salgadoensis.

\section{Phylogenetic Relationships}

The phylogenetic relationship of Pissarrachampsa sera within Baurusuchidae was examined with a maximum parsimony analysis of discrete morphological characters. The analysis was based on a new dataset constructed to address the morphological variation observed in Baurusuchidae. The taxon sampling scheme was conceived to incorporate a broad diversity of Baurusuchidae, with the ingroup composed of seven putative South American baurusuchids scored at the specific level (Pissarrachampsa sera, Baurusuchus albertoi, Baurusuchus pachecoi, Baurusuchus salgadoensis, Cynodontosuchus rothi, Stratiotosuchus maxhechti and Wargosuchus australis). Notosuchus terrestris, Mariliasuchus amarali, and Armadillosuchus arrudai were used as outgroups. The data sources for each taxon are given in Text S2. Some taxa that have been suggested to be baurusuchids or closely related to baurusuchids were excluded from the analysis. These include Bergisuchus dietrichbergi [26], Iberosuchus macrodon [24], Eremosuchus elkoholicus [25], Pabwehshi pakistanensis [17] and Pehuenchesuchus enderi [19]. These taxa were excluded a priori from the parsimony analysis because the baurusuchid affinity of these forms were repeatedly challenged within different phylogenetic frameworks of Mesoeucrocodylia [6,8,9,12,19,28-31]. Moreover, their fragmentary nature prevents both the identification of the apomorphic traits of the South American baurusuchids and the proposition of a unique suite of characters that can diagnose them as discrete baurusuchid taxa. Firsthand inspection of the holotype of Bergisuchus dietrichbergi (Hessisches Landesmuseum -Me 7003) and Iberosuchus macrodon (Museu Geológico- 5679), as well as descriptive accounts of these taxa [24,26,53], identified antorbital fenestrae and a broad contact between the nasal and frontal in Bergisuchus and five premaxillary teeth in Iberosuchus. Those characters are not present in any of the more complete undoubted South American baurusuchids. In the same way, the firsthand analysis of the holotype of Pehuenchesuchus enderi (Museo Municipal Argentino Urquiza -PV-CRS-440), along with its descriptive accounts [19], and the descriptive accounts of Eremosuchus elkoholicus (25) revealed the presence of sixteen alveoli in the dentary of Pehuenchesuchus and twelve in Eremosuchus, which is not congruent with the ten alveoli found in the dentary of the more complete undoubtful baurusuchids. Pabwehshi pakistanensis was excluded because it has a sagittal torus on its maxillary palatal shelves [9], absent in the putative baurusuchids.

Although many early and current analyses have recovered a close relationship between Baurusuchidae and Sebecidae, this is based on only six discrete characters: i.e., a deep rostrum, a well developed notch in premaxilla-maxilla suture, lateral surface of the dentary with longitudinal groove, a hypertrophied dentary tooth, ziphodont dentition, and a sigmoidal tooth row in dorsal view $[19,34]$. Recent analyses have challenged this hypothesis, also based on broad taxonomic and morphologic samplings [9]. Moreover, characters that distinguish the outgroup of the present analysis and baurusuchids outnumber the putatively shared traits between baurusuchids and sebecids, and few of the outgroup characters are present in sebecids. A detailed discussion of these aspects is presented below. A more detailed analysis of the sebecidbaurusuchid relationship is beyond the scope of the present work.

The outgroup was constructed based on the notosuchian affinity of Baurusuchidae $[6,54]$ accepted in most recent phylogenetic analyses [7-12,15,19,30,54-57]. Three taxa were used based on the completeness of material and their possible proximity to Baurusuchidae, estimated by the coding of the new characters presented here. Notosuchus terrestris [23] is used as the primary outgroup taxon and Mariliasuchus amarali [58] and Armadillosuchus arrudai [59] were added to promote a better resolution of character transformations through basal nodes of the ingroup.

Characters were selected focusing on the internal relationship of Baurusuchidae. Thirty-five new characters were added to a set of characters that previous mesoeucrocodylian phylogenetic analyses have recovered as synapomorphies of different clades (see Text S3). Autapomorphies for the terminal among are included in the list of character and in the matrix, but excluded at the analytical 
stage. The autapomorphies are included to strengthen the unique condition of the taxa, but also to be available for testing by further, broader Mesoeucrocodylia phylogenetic analyses. The matrix composed of 10 taxa and 66 characters (Text S4) was analyzed using the software TNT 1.1 [60] under the implicit enumeration algorithm. Different indices were calculated to verify the internal consistency of the data. In addition to consistency and retention indices for the tree topology, we performed a standard bootstrap analysis (1000 heuristic replicates) and calculated the decay index [61] for nodal support (see Figure 17).

\section{Discussion}

\section{Tree Topology}

The maximum parsimony analysis yielded a single tree (Figure 17) with 80 steps; see discussion below and Text S5 for the optimized synapomorphy list. The topology places Mariliasuchus amarali as the sister group of Armadillosuchus arrudai plus a monophyletic Baurusuchidae. Cynodontosuchus rothi is the most basal taxon within Baurusuchidae, sister to a dichotomy leading to a clade composed of Stratiotosuchus and all Baurusuchus species and a clade composed of Pissarrachampsa and Wargosuchus. Within Baurusuchus, B. albertoi is the sister taxon to a clade composed of B. pachecoi and B. salgadoensis.

\section{Phylogenetic definitions}

Baurusuchidae Price 1945.

Diagnosis. Small to medium-sized mesoeucrocodylians with premaxillae-maxillae suture internalized in a notch for the reception of lower caniniform; alveolar margin of maxilla in lateral view arched anterior to enlarged caniniform tooth; anterior extension of palatines not reaching the level of the anterior margin of suborbital fenestrae; presence of the posteroventral depressions in the mandibular symphysis; orientation of terminus of

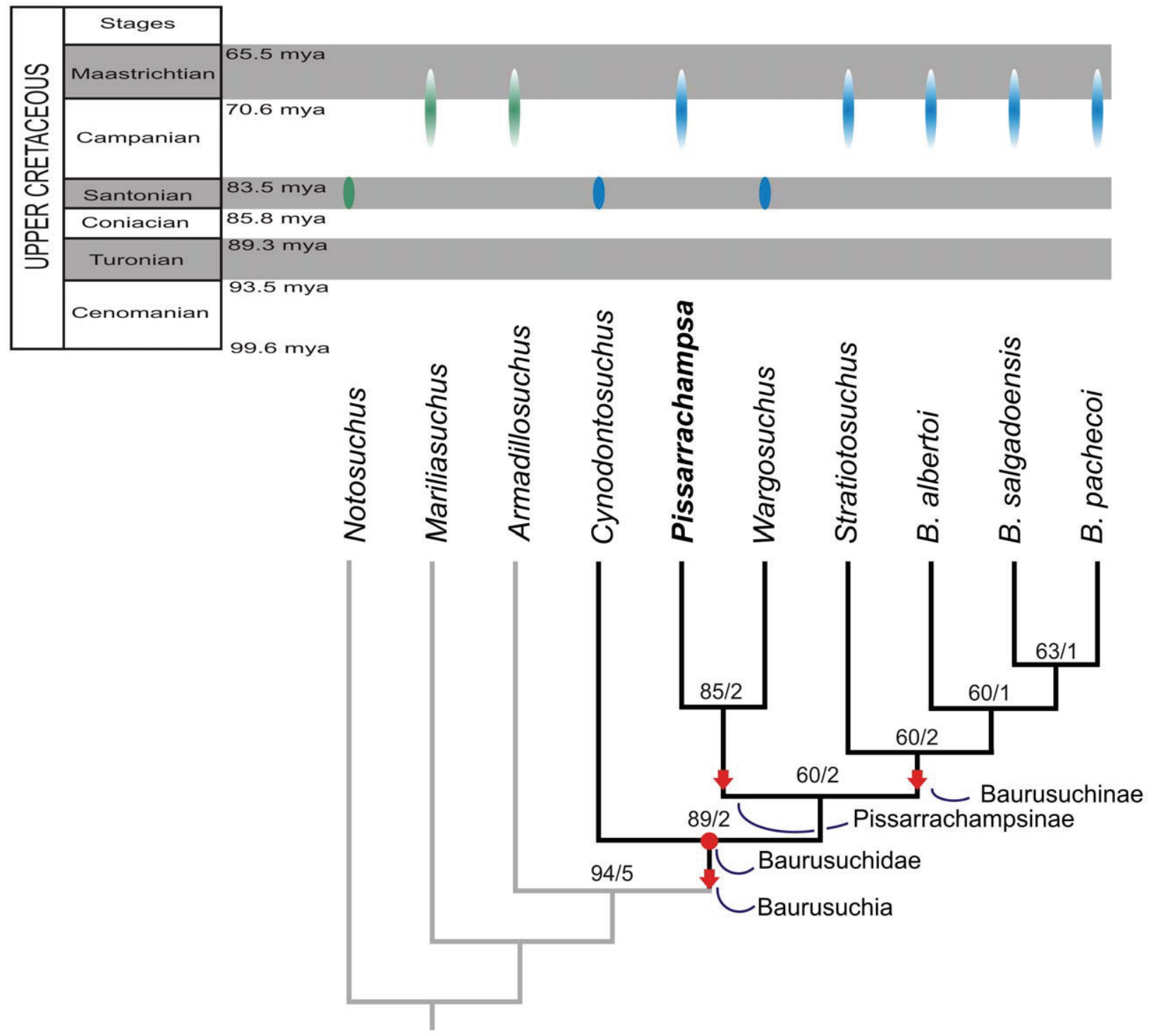

Figure 17. Phylogenetic relationships of Baurusuchidae depicting the position of Pissarrachampsa sera. The single most parsimonious tree (total length $=80$ steps; consistency index $=0.83$; retention index $=0.84$ ) recovered after maximum parsimony analysis using TNT. The bootstrap (50\% cut) and decay values are shown above the clades. Ages from [21,105] for Argentinean taxa and [101,102] for Brazilian taxa. Arrows assigned to stem-based taxa, and circle for node based.

doi:10.1371/journal.pone.0021916.g017 
mandibular symphysis anterodorsal, at approximately 45 degrees to jaw line; teeth with serrated mesial and distal carinae.

Etymology. Baurusuchidae was established as a family name on the basis of Baurusuchus pachecoi Price 1945 [1].

Phylogenetic definition. The least inclusive clade containing Cynodontosuchus rothi Woodward 1896 [23], Pissarrachampsa sera n. gen. n. sp., Stratiotosuchus maxhechti Campos, Suarez, Riff \& Kellner 2001 [62] and Baurusuchus pachecoi Price 1945 [1], as long as it does not include Notosuchus terrestris Woodward 1896 [23], Mariliasuchus amarali Carvalho \& Bertini 1999 [58], Armadillosuchus arrudai Marinho \& Carvalho 2009 [59], Araripesuchus gomesi Price 1959 [63], Sebecus icaeorhinus Simpson 1937 [64], Bretesuchus bonapartei Gasparini, Fernandez \& Powell 1993 [65], Peirosaurus tormini Price 1955 [66], or Crocodylus niloticus Laurent 1768 [67].

Discussion. The primary goal of this work is to examine baurusuchid ingroup relationships and determine a clear defifnition for Baurusuchidae (see Figure 17). The only available Baurusuchidae node-based definition [18] uses Baurusuchus and Stratiotosuchus as internal specifiers, and no external specifier was postulated.

Cynodontosuchus is historically important for Baurusuchidae because it was the first described member of the group [21,23], and associated, or even claimed to be congeneric, with Baurusuchus in early and current literature $[51,52,63,68-70]$. This compelled us to include Cynodontosuchus as an internal specifier in a phylogenetic definition of Baurusuchidae. Yet, if Cynodontosuchus turns out to be a juvenile specimen, or if its phylogenetic position within Baurusuchidae changes in future analyses, the defined clade remains stable (see below). We also included several other taxa as internal specifiers to better sample the morphological variation of the group. External specifiers were selected to avoid misapplication of the name in unlikely event that future alternative topologies recover those taxa as a paraphyletic assemblage.

\section{Baurusuchia Walker 1968.}

Diagnosis. Same as Baurusuchidae.

Etymology. The name was proposed [71,72] as a modififcation of the familiar name created earlier [1] to the infraorder level to reflect the opinion of the author regarding the highly modified morphology of the holotype of Baurusuchus pachecoi Price 1945. We choose to respect this earlier name and revise its definition to reflect its original intention to demarcate the highly divergent morphology of the clade.

Phylogenetic definition. Baurusuchus pachecoi Price 1945 [1] and all Crocodyliformes that share a more recent common ancestor with Baurusuchus pachecoi Price 1945 [1] than with Notosuchus terrestris Woodward 1896 [23], Mariliasuchus amarali Carvalho \& Bertini 1999 [58], Armadillosuchus arrudai Marinho \& Carvalho 2009 [59], Araripesuchus gomesi Price 1959 [63], Sebecus icaeorhinus Simpson 1937 [64], Bretesuchus bonapartei Gasparini, Fernandez \& Powell 1993 [65], Peirosaurus tormini Price 1955 [66], and Crocodylus niloticus Laurent 1768 [67].

Discussion. We propose Baurusuchia as a stem-based name to encompass Baurusuchidae, based on the large morphological gap between this clade and the outgroup (see below). In the present analysis, Baurusuchia is topologically identical to Baurusuchidae. Although these two taxa share the same diagnosis, our goal for this taxonomic decision is to minimize future, unnecessary taxonomic changes by providing a stable taxonomic framework for baurusuchian systematics.

\section{Pissarrachampsinae subfam. nov.}

Diagnosis. Medium sized baurusuchids with posterior portion of dorsal surface of the nasal bearing a rugose broad depression; approximation of prefrontals along their medial edges anteriorly; presence of a midline longitudinal depression on anterior portion of frontal.

Etymology. Named on the basis of Pissarrachampsa sera $\mathbf{n}$. gen. n. sp., the most complete member of the clade.

Phylogenetic definition. Pissarrachampsa sera n. gen. n. sp and all Crocodyliformes that share a more recent common ancestor with Pissarrachampsa sera n. gen. n. sp than with Stratiotosuchus maxhechti Campos, Suarez, Riff \& Kellner 2001 [62], Baurusuchus pachecoi Price 1945 [1], Notosuchus terrestris Woodward 1896 [23], Mariliasuchus amarali Carvalho \& Bertini 1999 [58], Armadillosuchus arrudai Marinho \& Carvalho 2009 [59], Araripesuchus gomesi Price 1959 [63], Sebecus icaeorhinus Simpson 1937 [64], Bretesuchus bonapartei Gasparini, Fernandez \& Powell 1993 [65], Peirosaurus tormini Price 1955 [66], and Crocodylus niloticus Laurent 1768 [67].

Discussion. The basal dichotomy of Baurusuchidae is well supported. Pissarrachampsinae is defined here as a stem-based clade to encompass its morphological unity as recovered in the present analysis.

\section{Baurusuchinae subfam. nov.}

Diagnosis. Medium sized baurusuchids with the medial contact for the prefrontals occurring along most of their dorsal medial edge; frontals broad, about twice the width of nasals; quadratojugal dorsal extension ending ventrally, or at the same level, of the dorsal tip of laterotemporal fenestra; quadrate fenestrae internalized in otic notch; muscle scar in the medial surface of quadrate (ridge 'A' [40]) almost straight to curved; ventral surface of choanal septum ridged.

Etymology. Named on the basis of Baurusuchus pachecoi Price 1945 [1], the first described member of the clade.

Phylogenetic definition. Baurusuchus pachecoi Price 1945 [1] and all Crocodyliformes that share a more recent common ancestor with Baurusuchus pachecoi Price 1945 [1] than with Pissarrachampsa sera n. gen. n. sp., Notosuchus terrestris Woodward 1896 [23], Mariliasuchus amarali Carvalho \& Bertini 1999 [58], Armadillosuchus arrudai Marinho \& Carvalho 2009 [59], Araripesuchus gomesi Price 1959 [63], Sebecus icaeorhinus Simpson 1937 [64], Bretesuchus bonapartei Gasparini, Fernandez \& Powell 1993 [65], Peirosaurus tormini Price 1955 [66], and Crocodylus niloticus Laurent 1768 [67].

Discussion. Baurusuchinae expands on the "practical use" of Baurusuchidae in previous phylogenetic analyses, which were limited to Baurusuchus and Stratiotosuchus (e. g: [29,30,33,34,73-75]) but see [31]. Here, we recognized this internal branch of Baurusuchidae as a well established, stem-based clade.

\section{Character Optimization and Discussion}

The proposed phylogenetic hypothesis is used here as a template to describe the evolutionary history of the unique morphology of Baurusuchidae, addressing the synapomorphies of the group and its internal clades. Cynodontosuchus rothi and Wargosuchus australis bear some problems for a complete discussion of character evolution in the clade, because of their fragmentary nature and large number of missing entries in the data matrix. We evaluate ambiguous character transformations for these poorly scored taxa using accelerated (ACGTRAN) and delayed (DELTRAN) transformation [76,77]. We agree that each case must be evaluated independently, and there is no overall best optimization method [78].

In the present dataset, alternative reconstructions of characters optimizations are more often caused by missing entries (characters 3, 5, 9, 11-14, 18, 19, 22, 23, 24, 27, 30, 31, 35, 37-41, 43, 45, 46, $48,49,51,53,54,56,58,60,61,62,64$, and 65 ), and only three cases are caused by a combination of missing entries and 
conflicting scoring for different taxa (characters 16, 32, and 33). The use of ACCTRAN is these cases would imply the presence of characters that are in fact not preserved in various taxa. Therefore, for the following discussion we adopted DELTRAN as the optimization procedure. This is a more conservative approach for the case at hand, and assigns the synapomorphies to the clades that in fact show the derived states.

Baurusuchidae is diagnosed by seven synapomorphies (characters $1.1,22.2,40.1,55.2,56.1,62.1$, and 64.1; character states are given after each character number, separated by a period), including those recovered unambiguously, as well by the optimization process. The presence of the premaxillae-maxillae suture internalized in a notch for the reception of lower caniniform (character 1.1), the alveolar margin of maxilla in lateral view arched anterior to enlarged caniniform tooth (character 22.2), and the teeth with serrated mesial and distal carinae (character 55.2) are character-states with multiple origins within Crocodyliformes. The same conditions are found in "protosuchian", Peirosauridae, Mahajangasuchidae, Eusuchia, and other taxa. The premaxillamaxillary notch and the serrated carinae are important characters in the context of the monophyly/paraphyly of Sebecosuchia (see [9] for more information). The same conditions are found in Sebecus, Bretesuchus, and Iberosuchus, and are considered as ambiguous synapomorphies of Sebecosuchia, when this clade is recovered in the analyses (e.g.,[12,13,34,79]). Yet, these characters represent ambiguous apomorphies for Baurusuchidae when Sebecosuchia is not recovered [30], showing that at some point the phylogenetic signal of these characters categorize Baurusuchidae. The palatine's anterior extension not reaching the level of the anterior margin of the suborbital fenestrae (character 40.1) and the presence of the posteroventral depressions in the mandibular symphysis are important new characters that represent delayed synapomorphies. The conditions found within Baurusuchidae are unique among Mesoeucrocodylia and are examples of the modified morphology of the group. The premaxillary dentition composed of three teeth (character 56.1) is a new apomorphy proposed for the group, which highlights its previously underestimated internal variation. A reduced dental formula is a general baurusuchid trait $[1,18,62]$, but when the internal branch pattern is taken into account, it is clear that a posterior increase in the premaxillary tooth number characterizes Baurusuchus. The anterodorsal orientation of the mandibular symphysis terminal portion at an angle of approximately 45 degrees to the jaw line (character 62.1 ) is confirmed in the present analysis as a baurusuchid synapomorphy, as in previous works [30].

A recovered clade grouping the baurusuchids above Cynodontosuchus (Figure 17) shows three new unambiguous synapomorphies: ventral face of palatine bar restricted and dorsal portion cylindrical (character 41.1), rugose medial palatal contact (character 42.1), and a row of foramina flanking the medial contact of palatines (character 44.1). These unique morphological traits are synapomorphies grouping the higher Baurusuchidae apart from Cynodontosuchus and evidence for an important morphological gap between Cynodontosuchus and the other taxa. In addition, 18 extra delayed synapomorphies characterize this clade (characters 5.1, 9.1, 12.2, 14.1, 18.1, 19.1, 23.1, 24.1, 27.2, $31.1,33.1,37.1,38.1,45.1,51.1,54.1,60.1$ and 61.1). These characters are not scored for Cynodontosuchus, but are evidence for the huge morphological changes basal to, or within basal Baurusuchidae. These are a combination of characters previously recognized in the literature as synapomorphies at different levels of mesoeucrocodylian phylogeny, plus a great number of characters proposed here. Among them, the median approximation of prefrontal and the lateral depression of quadrate are tested here under maximum parsimony, turning to be phylogenetically relevant as previously proposed $[21,80]$. In addition, a character previously discussed in the literature concerning baurusuchids is the presence of a triangular depression on the lateral surface of the jugal ([81]: character 133; [6]: character 145), deemed as a synapomorphy of sphagesaurids and Sebecosuchia (e.g.: $[6,13,34])$. Based on a close examination of baurusuchids and outgroup taxa, this character was split in two (characters, 27 and 45). The depression is interpreted here as a combination of two features: the displacement of the lateral surface of the infratemporal portion of the jugal, extending anteriorlly and reaching the orbital anterior edge, and the ridged ectopterygoidjugal suture. The first state is a further modification of a feature also recognized in some outgroup taxa (Mariliasuchus and Armadillosuchus), as well other forms not included in the present analysis (e.g., Sphagesaurus, Yacarerani, Adamantinasuchus). The second character is unique to the clade. The combination of these two features, plus the infraorbital portion of the jugal being twice as large as the infratemporal portion, exacerbates the condition for Baurusuchinae and leaded to the oversimplification of the character in previous analyses.

Pissarrachampsa sera is positioned as sister clade to Wargosuchus australis, forming Pissarrachampsinae. This association is based on three synapomorphies: posterior portion of dorsal surface of the nasal bearing a rugose broad depression (character 4.1), prefrontal medial margins anteriorly convergent (character 5.1), and presence of a midline longitudinal depression on anterior portion of frontal (character 10.1). Among these characters, only the presence of the broad depressed area on the posterior portion of the nasal was not considered as an autapomorphy of Wargosuchus in its original description [21]. On the other side, the taxa differ based on a groove between the prefrontal and anterior palpebral dorsal surfaces (character 6.1) and a small contact between nasal and frontal, both present only in Wargosuchus [21], and the autapomorphic position of the lacrimal duct in Pissarrachampsa (character 20), contrasted to the plesiomorphic condition in Wargosuchus. Considering the fragmentary nature of Wargosuchus, the number of synapomorphies and differences are enough to respectively accept them forming a monophyletic group, but representing different genera.

Baurusuchinae shares medial contact of the prefrontals most of their dorsal medial edge (character 5.2); frontals broader, about twice the width of nasals (character 8.1); quadratojugal dorsal extension ending ventrally, or at the same level, of the dorsal tip of laterotemporal fenestra (character 32.0); quadrate fenestrae internalized in otic notch (character 34.1); muscle scar in the medial surface of quadrate (ridge 'A' [40]) almost straight to curved (character 36.0); and ridging of the ventral surface of the choanal septum (character 47.1). Additionally, two delayed character states diagnose this clade: the frontal longitudinal crest restricted to the posterior portion (character 11 state 1 ); and the quadrate depression main axis is dorsoventrally oriented (character 33 state 1). The presence of multiple quadrate fenestrae (or preotic siphonal foramina, sensu $[15,30,82])$ is known in protosuchians $[13,30,34]$ and notosuchians, and is especially evident and studied in Notosuchus and Mariliasuchus (see [83]). In the present paper we recognized a fenestrate quadrate also in Armadillosuchus and Baurusuchidae. However, within Baurusuchidae, only Pissarrachampsa sera exposes these fenestrae in lateral view. Baurusuchines posses a modified condition, in which the four quadrate fenestrae are enclosed in the otic notch and only the anteriormost is partially visible in lateral view. The function of the quadrate fenestrae have not been discussed previously and is beyond the 
scope of this work, but a relationship to auditory function is possible.

Baurusuchus is diagnosed by an antorbital region of the jugal more expanded than the infraorbital region (character 25) and two delayed synapomorphies: major surface of pterygoid wing lateroventrally oriented (character 48) and musculus pterygoideous posterior insertion in a marked depression on the surangular-angular lateral surface (character 61). Baurusuchus pachecoi shares with B. salgadoensis the ectopterygoid-jugal suture ridge continuous with the ventral ridge of the infratemporal portion of jugal (character 45) and three delayed synapomorphies: cylindrical dorsal portion of palatine constricted posteriorly (character 41 state 2), premaxillae bearing four teeth (character 56), and last premaxillary tooth not hypertrophied (character 58). The new interpretation of the jugal antorbital triangular depression (see discussion above) leads to the recognition of a ridged ectopterygoid-jugal suture. Pissarrachampsa, Stratiotosuchus, and Baurusuchus albertoi show this ridge ending in a well marked notch (see Figure 10), which separates this structure from the displaced lateral surface of the infratemporal portion of the jugal. In contrast, $B$. pachecoi and $B$. salgadoensis have a smooth transition between these ridges, and no notch is observed.

\section{Predictions for future stability of the nomenclatural acts proposed}

Two predictions are considered here with possible consequences to the nomenclatural acts proposed. Cynodontosuchus has a unique suite of characters that seems best explained by advocating a distinct taxonomic assignment for it. However, alternative scenarios may also explain those differences and lead to another interpretation of its status, as the suggestion of Cynodontosuchus representing a juvenile Baurusuchus [51,52]. In addition to its relatively small size, the presence of smoother bone sculpturing may be a result of fewer resorption-reconstruction cycles, which is also characteristic of early ontogenetic stage in many tetrapod groups [84-87]. Assuming this scenario, the absence in Cynodontosuchus of the palatal median rogosity and its flanking foramina rows, which is present in higher baurusuchids, can also be interpreted as a juvenile condition given that singular structures develop latter in ontogeny [84,88-92]. The absence of hypertrophied teeth in the premaxilla can also be consistent with this alternative interpretation, because juveniles of extant Crocodylia tend to have teeth with less size differentiation ([84]; HCEL pers. observ.). In addition, the closely associated taxon Notosuchus terrestris also presents a progressive development of caniniform teeth during ontogeny [93]. The exact provenance of Cynodontosuchus is not known $[52,69,94]$, but based on its association with Notosuchus [23], it is reasonable to assume an origin within the Bajo de La Carpa Formation $[21,29,52,69,94]$, which also yielded Wargosuchus. The presence of both Wargosuchus and Cynodontosuchus in the same stratigraphic unit may suggest that they represent different ontogenetic stages of the same taxon, instead of two sympatric baurusuchids. If Cynodontosuchus represents a juvenile Wargosuchus, the Baurusuchidae node would move to the PissarrachampsinaeBaurusuchinae dichotomy. The stem-based Baurusuchia was proposed to accommodate future new taxa that may lie outside Baurusuchidae but are clearly more closely related to the baurusuchid clade than the other notosuchians. New taxa are predicted to be found along this stem, because of the large morphological gap between known baurusuchids and their notosuchian sister groups. The stem-based definition will easily accommodates any future new taxa, maintaining the morphological unity of Baurusuchidae, and not pose further taxonomic rearrangements.

\section{Biostratigraphical Implications}

Pissarrachampsa sera comes from the Triângulo Mineiro, in Minas Gerais, where the Vale do Rio do Peixe Formation has some of its northernmost surface exposures. This region has received less paleontological attention than the Marilia Formation near Peirópolis, also in Triângulo Mineiro, where a large number of tetrapod taxa have been recovered [66,69,95-99]. The Vale do Rio do Peixe Formation corresponds mainly to the Adamantina Formation in more conventional stratigraphic schema [100], which has been dated at Turonian-Santonian and CampanianMaastrichtian from strata in São Paulo state [101,102]. The latter date is more likely, given the correlation based on vertebrates to nearby Campanian-Maastrichtian stratigraphic units [102-104]. In the more southern São Paulo state, the Vale do Rio do Peixe Formation has yielded four baurusuchid species (Figure 2), whereas Pissarrachampsa sera is the only baurusuchid known from Minas Gerais. However, the stratigraphic correlation between these northern and southern exposures of the Vale do Rio do Peixe Formation has not been fully determined.

The phylogenetic results presented here have interesting biostratigraphic implications. Baurusuchines are restricted to the Vale do Rio do Peixe Formation of São Paulo state, suggesting that the four species were either living in sympatry, are in fact stratigraphically isolated, or a combination of both. Wargosuchus comes from the Bajo de la Carpa Formation, which has been assigned a Santonian age $[21,94,105]$. Pissarrachampsinae then either spans at least 20 million years, or corroborates the older age for the Vale do Rio do Peixe Formation [101], at least in Minas Gerais. Another possibility is a younger age for the not so well constrained Bajo de La Carpa Formation. Pissarrachampsinae also spans at least two depositional basins, whereas Baurusuchinae are endemic to a single basin.

Baurusuchia may be one of the most geographically and stratigraphically restricted radiations of crocodyliforms, but they have a relatively large morphological gap in relation to their closest sister taxa. Further discoveries are expected to fill in this gap and may expand the temporal and spacial range of the lineage. The only comparable crocodyliform clade, in terms of morphological distinctiveness and chronological/geographical restriction, is Mahajangasuchidae. The extreme morphological divergences of these taxa, compared to their sister clades, may in fact be partially explained by their temporal and spatial restrictions, similar to some extant isolated clades today.

\section{Conclusions}

Pissarrachampsa sera is a distinct new baurusuchid from the Vale do Rio do Peixe Formation. The species' phylogenetic position was tested under a new morphological data set focusing on the differentiated morphology of the diagnostic members of the group. The data support a monophyletic Baurusuchidae and an internal split into Pissarrachampsinae, composed of Wargosuchus from Argentina and Pissarrachampsa described here, and Baurusuchinae composed of Stratiotosuchus and the three species of Baurusuchus. The morphological data support a big morphological gap between Baurusuchidae and its outgroups. Additionally, the affinity between Wargosuchus and Pissarrachampsa suggest an older age (possibly Santonian) for the Vale do Rio do Peixe Formation in Minas Gerais State.

\section{Supporting Information}

Text S1 Revised diagnosis of baurusuchid species of the ingroup included in the analyses. The specimens circumscribed in each proposed diagnosis are listed. The references for 
the unique characters previously proposed are given Cynodontosuchus rothi [94], Baurusuchus pachecoi [94], Stratiotosuchus maxhechti [80], Baurusuchus salgadoensis [74] and Baurusuchus albertoi [22]. The referred material of Stratiotosuchus maxhechti was described by [80], but see Text S1.

(DOC)

Text S2 OTUS used in Parsimony Analysis. Specimens studied firsthand are listed. Descriptive accounts taken for the scoring of the OTUS are following Notosuchus terrestris [29,83,108], Mariliasuchus amarali [103,109], Armadillosuchus arrudae [59], Baurusuchus pachecoi $[1,18,22,110]$, Stratiotosuchus maxhechti [62,80], Baurusuchus salgadoensis [18,111], Wargosuchus australis [21] and Baurusuchus albertoi $[22,112]$.

(DOC)

Text S3 List of characters used in phylogenetic analysis. The 66 characters used in the phylogenetic analyses are described (along with the character-states). The character-taxon matrix is presented in Text S4. Characters are either new or adapted from previously published studies. Character 1 was adapted from [4] (character 9), [11](character 65), [30] (character 103), [34] (character: 9); character 2 was adapted from [112] (character 257); character 7 was adapted from [4] (character 23), [113] (character 81); character 8 was modified from [4] (character 20); character 9 was adapted from[75] (Character 260); character 11 was adapted from [4] (character 23); character 12 was modified from [79](character247); character 14 was adapted from [115] (character 6), [4] (characters 19), [114] (character 80); character 16 was adapted from [74] (Character 258); character 17 was adapted from [6] (character 157); character 18 was adapted from [4] (characters 35 and 36) and [114] (character 140); character 19 was adapted from [4] (character 36); character 21 was adapted from [55] (character 181); character 22 was adapted from [4] (character 79) and [30] (character 107); character 24 was adapted from [81] (character 144); character 25 was adapted from [81] (character 144); character 26 was adapted from [114] (character 139); character 27 was adapted from [81] (character 133), [6] (character 145), [12] (character 121), [116] (character 46); character 28 was adapted from [4] (character 18); character 33 was adapted from

\section{References}

1. Price LI (1945) A new reptil from the Cretaceous of Brazil. Notas Preliminares e Estudos - Divisão de Geologia e Mineralogia, Rio de Janeiro - Brasil 25: 1-8.

2. Benton M, Clark JM (1988) Archosaur phylogeny and the relationships of the Crocodylia. In: Benton M, ed. The phylogeny and classification of the tetrapods. Oxford: Clarendon Press. pp 295-338.

3. Buckley GA, Brochu CA (1999) An enigmatic new crocodile from the Upper Cretaceous of Madagascar. Special Papers in Palaeontology 60: 149-175.

4. Clark JM (1994) Patterns of evolution in Mesozoic Crocodyliformes. In: Fraser NC, Sues H-D, eds. In the shadow of dinosaurs. Cambridge: Cambridge University. pp 84-97.

5. Gasparini Z, Chiappe LM, Fernandez M (1991) A new Senonian peirosaurid (Crocodylomorpha) from Argentina and a synopsis of the South American Cretaceous crocodilian. Journal of Vertebrate Paleontology 11: 316-333.

6. Ortega F, Gasparini Z, Buscalioni AD, Calvo JO (2000) A new species of Araripesuchus (Crocodylomorpha, Mesoeucrocodylia) from the lower Cretaceous of Patagonia (Argentina). Journal of Vertebrate Paleontology 20: $57-76$

7. Buckley GA, Brochu CA, Krause DW, Pol D (2000) A pug-nosed crocodyliform from the Late Cretaceous of Madagascar. Nature 405: 941-944.

8. Company J, Suberbiola XP, Ruiz-Omeñaca JI, Buscalioni AD (2005) A new species of Doratodon (Crocodyliformes: Ziphosuchia) from the Late Cretaceous of Spain. Journal of Vertebrate Paleontology 25: 343-353.

9. Larsson HCE, Sues H-D (2007) Cranial osteology and phylogenetic relationships of Hamadasuchus rebouli (Crocodyliformes: Mesoeucrocodylia) from the Cretaceous of Morocco. Zoological Journal of the Linnean Society 149: 533-567.

10. Pol D, Ji S-a, Clark JM, Chiappe LM (2004) Basal crocodyliforms from the Lower Cretaceous Tugulu Group (Xinjiang, China) and the phylogenetic position of Edentosuchus. Cretaceous Research 25: 603-622.
[74]; character 38 was adapted from [30] (character 57); character 50 was adapted from [116] (character 103); character 54 was adapted from [55] (character 179); character 55 was modified from [27] (character 11), [30] (character 114); character 56 was adapted from [117] (character 27), [6] (character 133); character 57 was adapted from [4] (character 78); character 58 was adapted from [4] (character 78); character 59 was adapted from [116] (character 30); character 61 was adapted from [6] (character 90); character 62 was adapted from [30] (character 178); character 63 was adapted from [56] (character 181); character 65 was aAdapted from [4] (character 76), [30] (character 201); character 66 was adapted from[74].

(DOC)

\section{Text S4 Gharacter-State Matrix.}

(DOC)

\section{Text S5 Synapomorphy List.}

(DOC)

\section{Acknowledgments}

We are indebted to Alberto Garrido, Alejandro Kramarz, Alexander Kellner, Antonio Celso Arruda-Campos, Arturo Muñoz Saravia, Deise Henriques, Diego Pol, Domenica Santos, Eduardo Ruigomez, Felipe M. Vasconcellos, Fernando Novas, Flávia Coelho, Gladis Retamal, Ismar S. Carvalho, Jorge Calvo, Juan Porfiri, Lucas Pomi, Marcelo Reguero, Martin Ezcurra, Miguel Ramalho, Norbert Micklich, Ricardo Cespedes Paz, Sandra Tavares, and Thiago S. Marinho, who allowed the study of specimens under their care and helped in different ways during the museum visits. We are also indebted to Alessandro Batezelli for information on regional geology. This contribution used TNT ver 1.1, a program made freely available thanks to a subsidy by the Willi Hennig Society.

\section{Author Contributions}

Conceived and designed the experiments: FCM HCEL MCL. Performed the experiments: FCM HCEL MCL. Analyzed the data: FCM HCEL MCL. Contributed reagents/materials/analysis tools: FCM HCEL MCL. Wrote the paper: FCM HCEL MCL.

11. Pol D, Norell MA (2004) A new crocodyliform from Zos Canyon, Mongolia. American Museum Novitates 3445: 1-36.

12. Turner A, Buckley GA (2008) Mahajangasuchus insignis (Crocodyliformes: Mesoeucrocodylia) cranial anatomy and new data on the origin of the eusuchian-style palate. Journal of Vertebrate Paleontology 28: 382-408.

13. Turner A, Sertich JJW (2010) Phylogenetic history of Simosuchus clarki (Crocodyliformes: Notosuchia) from the Late Cretaceous of Madagascar. Journal of Vertebrate Paleontology 30: 177-236.

14. Tykosky RS, Rowe TB, Ketcham RA, Colbert MW (2002) Calsoyasuchus valliceps, a new crocodyliform from the early Jurassic Kayenta Formation of Arizona. Journal of Vertebrate Paleontology 22: 593-611.

15. Sereno PC, Sidor CA, Larsson HCE, Gado B (2003) A new notosuchian from the early Cretaceous of Niger. journal of Vertebrate Paleontology 23: 477-482.

16. Turner A (2004) Crocodyliform biogeography during the Cretaceous: biogeographical analysis. Proceedings of the Royal Society of London B 271: 2003-2009.

17. Wilson JA, Malkani MS, Gingerich PD (2001) New crocodyliform (Reptilia, Mesoeucrocodylia) from the Upper Cretaceous Pab Formation of Vitakri, Balochistan (Pakistan). Contributions from the Museum of Paleontology, University of Michigan 30: 321-336.

18. Carvalho IS, Campos ACA, Nobre PH (2005) Baurusuchus salgadoensis, a new Crocodylomorpha (Cretaceous), Brazil. Gondwana Research 8: 11-30.

19. Turner A, Calvo JO (2005) A new sebecosuchian crocodyliform from the Late Cretaceous of Patagonia. Journal of Vertebrate Paleontology 25: 87-98.

20. Campos DA, Suarez JM (1988) Um novo Baurusuchidae (Reptilia, Crocodylia) do Cretáceo Superior do Estado de São Paulo. Anais da Academia Brasileira de Ciências 60: 492.

21. Martinelli AG, Pais DF (2008) A new baurusuchid crocodyliform (Archosauria) from the Late Cretaceous of Patagonia (Argentina). Systematic Palaeontology 7: $371-381$. 
22. Nascimento PM, Zaher H (2010) A new species of Baurusuchus (Crocodyliformes, Mesoeucrocodylia) from the Upper Cretaceous of Brazil, with the first complete postcranial skeleton described for the family Baurusuchidae. Papéis Avulsos de Zoologia 50: 323-361.

23. Woodward AS (1896) On two Mesozoic crocodilians, Notosuchus (genus novum) and Cynodontosuchus (genus novum) from the red sandstones of the territory of Neuquén (Argentina). Anales Museo de La Plata 4: 1-20.

24. Antunes MT (1975) Iberosuchus, crocodile Sébécosuchien nouveau. L'Eocène ibérique au nord de la Chalne centrale, et l'origine du canyon de Nazaré. Comunicações dos Serviços Geologicos de Portugal 59: 285-330.

25. Buffetaut E (1989) A new ziphodont mesosuchian crocodile from the Eocene of Algeria. Palaeontographica 208: 1-10.

26. Kuhn O (1968) Die Vorzeitlichen Krokodile. Krailing: Oeben. 124 p.

27. Ortega F, Buscalioni AD, Gasparini Z (1996) Reinterpretation and new denomination of Atacisaurus crassiporatus (Middle Eocene; Issel, France) as cf. Iberosuchus (Crocodylomorpha, Metasuchia). Géobios 29: 353-364.

28. Fiorelli LE, Calvo JO (2007) The first "protosuchian" (Archosauria: Crocodyliformes) from the Cretaceous (Santonian) of Gondwana. Arquivos do Museu Nacional 65: 417-459.

29. Fiorelli LE, Calvo JO (2008) New remains of Notosuchus terrestris Woodward 1896 (Crocodyliformes: Mesoeucrocodylia) from Late Cretaceous Neuquèn, Patagonia, Argentina. Arquivos do Museu Nacional 66: 83-124.

30. Sereno PC, Larsson HCE (2009) Cretaceous crocodyliforms from the Sahara. Zookeys 28: 1-143.

31. Pol D, Powell J A new sebecid mesoeucrocodylian from the Rio Loro Formation (Paleocene) of Northwestern Argentina. Zoological Journal of the Linnean Society, (in press).

32. Lauprasert K, Cuny G, Thirakhupt K, Suteethorn V (2009) Khoratosuchus jintasakuli gen. et sp. nov., an advanced neosuchian crocodyliform from the Early Cretaceous (Aptian-Albian) of NE Thailand. Geological Society, London, Special Publications 315: 175-187.

33. O'Connor PM, Sertich JJW, Stevens NJ, Roberts EM, Gottfried MD, et al. (2010) The evolution of mammal-like crocodyliforms in the Cretaceous Period of Gondwana. Nature 466: 748-751.

34. Pol D, Turner A, Norell MA (2009) Morphology of the Late Cretaceous crocodylomorph Shamosuchus djachtaensis and a discussion of neosuchian phylogeny as related to the origin of Eusuchia. Bulletin of American Museum of Natural History 324: 1-103.

35. Fernandes LA, Coimbra AM (1996) A Bacia Bauru (Cretáceo Superior, Brasil). Anais da Academia Brasileira de Ciências 68: 105-195.

36. Fernandes LA, Coimbra AM (2000) Revisão estratigráfica da parte oriental da Bacia Bauru (Neocretáceo). Revista Brasileira de Geociências 30: 717-728.

37. Whetstone KN, Whybrow P (1983) A Cursorial Crocodilian from the Triassic of Lesotho (Basutiland, South Africa). Occasional Papers of the Museum of Natural History, University Kansas 106: 1-37.

38. Busbey AB (1995) The structural consequences of skull flattening in crocodilians. In: Thomason J, ed. Functional morphology in vertebrate paleontology. New York: Cambridge University Press. pp 173-192.

39. Iordansky NN (1964) The jaw muscles of the crocodiles and some relating structures of the crocodilian skull. Anatomischer Anzeiger 115: 256-280.

40. Iordansky NN (1973) The skull of the Crocodylia. In: Gans C, ed. Biology of Reptilia. New York: Academic Press. pp 201-262.

41. Romer AS (1956) Osteology of the Reptiles. Chicago: The University of Chicago Press. 772 p.

42. Tarsitano SF (1989) The evolution of the crocodilia: a conflict between morphological and biochemical data. American Zoologist 29: 843-856.

43. Holliday CM, Witmer LM (2009) The epipterygoid of Crocodyliforms and its significance for the evolution of the orbitotemporal region of eusuchians. Journal of Vertebrate Paleontology 29: 715-733.

44. Tsuihiji T (2007) Homologies of the longissimus, iliocostalis, and hypaxial Muscles in the anterior presacral region of extant Diapsida. Journal of Morphology 268: 986-1020.

45. Prasad GVR, Lapparent de Broin F (2002) Late Cretaceous crocodile remains from Naskal (India): comparisons and biogeographic affinities. Annales de Paléontologie 82: 19-71.

46. Smith JB, Dodson P (2003) A proposal for a standard terminology of anatomical notation and orientation in fossil vertebrate dentitions. Journal of Vertebrate Paleontology 23: 1-12.

47. Witmer LM (1997) The evolution of the antorbital cavity of archosaurus: a study in soft-tissue reconstruction in the fossil record with analysis of the function of pneumaticity. Memoirs of the Society of Vertebrate Paleontology 17: $1-76$.

48. Shute CCD, Bellairs AA (1955) The external ear in Crocodylia. Proceedings of the Zoological Society of London 124: 741-748

49. Holliday CM, Witmer LM (2007) Archosaur adductor chamber evolution: integration of musculoskeletal and topological criteria in jaw muscle homology. Journal of Morphology 268: 457-484.

50. Colbert EH (1946) Sebecus, representative of a peculiar suborder of fossil crocodilia from Patagonia. Bulletin of American Museum of Natural History 87: $217-270$.

51. Gasparini Z (1972) Los Sebecosuchia (Crocodilia) del territorio argentino. Consideraciones sobre su "status" taxonomico. Ameghiniana IX: 23-34

52. Gasparini Z (1981) Los Crocodylia fosiles de la Argentina. Ameghiniana XVIII: $177-205$
53. Rossmann T, Rauhe M, Ortega F (2000) Studies on Cenozoic crocodiles 8. Description of Bergisuchus dietrichbergi Kühn (Sebecosuchia: Bergisuchidae n. fam.) from the Middle Eocene of Germany, and some new systematic and biological conclusions. Paläontologische Zeitschrift 74: 379-392.

54. Sereno PC, Larsson HCE, Sidor CA, Gado B (2001) The giant Crocodyliform Sarcosuchus from the Cretaceous of Africa. Science 294: 1516-1519.

55. Pol D, Norell MA (2004) A new gobiosuchid crocodyliform taxon from the Cretaceous of Mongolia. American Museum Novitates 3458: 1-31.

56. Pol D, Apesteguia S (2005) New Araripesuchus remains from the Early Late Cretaceous (Cenomanian-Turonian) of Patagonia. American Museum Novitates 3490: 1-38.

57. Young MT, Andrade MB (2009) What is Geosaurus? Redescription of Geosaurus giganteus (Thalattosuchia: Metriorhynchidae) from the Upper Jurassic of Bayern, Germany. Zoological Journal of the Linnean Society 157: 551-585.

58. Carvalho IS, Bertini RJ (1999) Mariliasuchus, um novo Crocodylomorpha (Notosuchia) do Cretáceo da Bacia Bauru, Brasil. Geologia Colombiana 24: 83-105.

59. Marinho TS, Carvalho IS (2009) An armadillo-like sphagesaurid crocodyliform from the Late Cretaceous of Brazil. Journal of South American Earth Sciences 27: 36-41.

60. Goloboff P, Farris J, Nixon K (2008) TNT, a free program for phylogenetic analysis. Cladistics 24: 774-786

61. Bremer K (1988) The limits of amino acid sequence data in angiosperm phylogenetic reconstruction. Evolution 42: 795-803.

62. Campos DA, Suarez JM, Riff D, Kellner AWA (2001) Short note on a new Baurusuchidae (Crocodyliformes, Metasuchia) from the Upper Cretaceous of Brazil. Boletim do Museu Nacional 57: 1-8

63. Price LI (1959) Sobre um crocodilídeo notossúquio do Cretácico brasileiro. Boletin da Divisão de Geologia e Mineralogia, Departamento Nacional da Produção Mineral 188: 1-55.

64. Simpson GG (1937) New reptiles from the Eocene of South America. American Museum Novitates 927: 1-3.

65. Gasparini Z, Fernandez M, Powell J (1993) New Tertiary sebecosuchians (Crocodylomorpha) from South America: phylogenetic implications. Historical Biology 7: 1-19.

66. Price LI (1955) Novos Crocodilídeos dos Arenitos da Série Baurú, Cretáceo do Estado de Minas Gerais. Divisão de Geologia e Mineralogia do Departamento Nacional da Produção Mineral, Rio de Janeiro, D F 27: 487-498.

67. Laurenti JN (1768) Specimen medicum, exhibens synopsin reptilium emendatam cum experimentis circa venena et antidota reptilium austracorum, quod authoritate et consensu. Vienna: Joan Thomae, Vindobonae. 217 p.

68. Buffetaut E (1980) Histoire biogéographique des Sebecosuchia (Crocodylia, Mesosuchia): un essai d'interprétation. Annales de Paléontologie (Vertébrés) 66: $1-18$.

69. Candeiro CRA, Martinelli AG (2006) A review of paleogeographical and chronostratigraphical distribution of mesoeucrocodylian species from the upper Cretaceous beds from the Bauru (Brazil) and Neuquén (Argentina) groups, Southern South America. Journal of South American Earth Sciences 22: 116-129.

70. Carvalho IS, Gasparini Z, Salgado L, Vasconcellos FM, Marinho TS (2010) Climate's role in the distribution of the Cretaceous terrestrial Crocodyliformes throughout Gondwana. Palaeogeography, Palaeoclimatology, Palaeoecology 297: 252-262.

71. Walker AD (1968) Protosuchus, Proterochampsa, and the origin of phytosaurs and crocodiles. Geological Magazine 105: 1-14.

72. Walker AD (1970) A revision of the jurassic reptile Hallopus victor (Marsh), with remarks on the classification of crocodiles. Philosophical Transactions of the Royal Society of London, Series B 257: 323-372.

73. Leardi JM, Pol D (2009) The first crocodyliform from the Chubut Group (Chubut Province, Argentina) and its phylogenetic position within basal Mesoeucrocodylia. Cretaceous Research 30: 1376-1386.

74. Nascimento PM, Zaher H The skull of the Upper Cretaceous baurusuchid crocodile Baurusuchus albertoi Nascimento \& Zaher, 2010, and its phylogenetic affinities. Zoological Journal of the Linnean Society, (in press).

75. Riff D Baurusuchid crocodyliforms as theropod mimics: clues from the skull and appendicular morphology of Stratiotosuchus maxhechti (Upper Cretaceous of Brazil). Zoological Journal of the Linnean Society, (in press).

76. Farris J (1970) Methods for computing Wagner trees. Systematic Zoology 19: 83-92.

77. Swofford DL, Maddison WP (1987) Reconstructing ancestral character states under Wagner Parsimony. Mathematical Biosciences 87: 199-229.

78. Agnarsson I, Miller JA (2008) Is ACCTRAN better than DELTRAN? Cladistics 24: 1-7

79. Pol D, Gasparini Z (2009) Skull anatomy of Dakosaurus andiniensis (Thalattosuchia: Crocodylomorpha) and the phylogenetic position of Thalattosuchia. Journal of Systematic Palaeontology 7: 163-197.

80. Pinheiro AEPC, Andrade MB, Neto RGM (2008) A new specimen of Stratiotosuchus maxhechti (Baurusuchidae, Crocodyliformes) from the Adamantina Formation (Upper Cretaceous), southeastern Brazil. Revista Brasileira de Paleontologia 11: 37-50.

81. Pol D (1999) El esqueleto postcraneano de Notosuchus terrestris (Archosauria: Crocodyliformes) del Cretácico Superior de la Cuenca Neuquina y su información fi logenética. Buenos Aires: Universidad de Buenos Aires. 158 p. 
82. Brochu CA, Bouaré ML, Sissoko F, Roberts EM, O’Leary MA (2002) A dyrosaurid crocodyliform braincase from Mali. Journal of Paleontology 76: $1060-1071$

83. Andrade MB, Bertini RJ (2008) Morphological and anatomical observations about Mariliasuchus amarali and Notosuchus terrestris (Mesoeucrocodylia) and their relationships with other South American notosuchians. Arquivos do Museu Nacional 66: 5-62.

84. Mook CG (1921) Individual and age variations in the skulls of recent Crocodilia. Bulletin of American Museum of Natural History 44: 51-66.

85. Barry TH (1957) On the significance of tuskless specimens of Dicynodon grimbeeki Broom. Palaeontologia Africana 5: 57-66.

86. Buffrénil V (1982) Morphogenesis of bone ornamentation in extant and extinct crocodilians. Zoomorphology 99: 155-166.

87. Hill RV, Witmer LM, Norell MA (2003) A new specimen of Pinacosaurus grangeri (Dinosauria: Ornithischia) from the Late Cretaceous of Mongolia: ontogeny and phylogeny of ankylosaurs. American Museum Novitates 3395: 1-29.

88. Horner JR, Goodwin MB (2006) Major cranial changes during Triceratops ontogeny. Proceedings of the Royal Society of London B 273: 2757-2761.

89. Horner JR, Goodwin MB (2009) Extreme cranial ontogeny in the Upper Cretaceous dinosaur Pachycephalosaurus. PLoS ONE 4: 1-11.

90. Larsson HCE (1998) A new method for comparing ontogenetic and phylogenetic data and its application to the evolution of the crocodilian secondary palate. Neues Jahrbuch fur Geologie und Palaontologie, Abhandlungen 210: 345-368.

91. Martill DM, Naish D (2006) Cranial crest development in the azhdarchoid pterosaur Tupuxuara with a review of the genus and tapejarid monophyly. Palaeontology 49: 925-941.

92. Steyer J-S (2000) Ontogeny and phylogeny in temnospondyls: a new method of analysis. Zoological Journal of the Linnean Society 130: 449-467.

93. Lecuona A, Pol D (2008) Tooth morphology of Notosuchus terrestris (Notosuchia: Mesoeucrocodylia): new evidence and implications. Comptes Rendus Palevol 7: 407-417.

94. Pol D, Gasparini Z (2007) Crocodyliformes. In: Gasparini Z, Salgado L, Coria RA, eds. Patagonian Mesozoic Reptiles. Bloomington \& Indianapolis: Indiana University Press. pp 116-142.

95. Baez AM, Peri S (1989) Baurubatrachus pricei, nov. gen. et sp., un anuro del Cretácico Superior de Minas Gerais, Brazil. Anais da Academia Brasileira de Ciências 61: 447-458.

96. Candeiro CRA, Abranches CT, Abrantes EA, Avilla LS, Martins VC, et al. (2004) Dinosaur remains from western São Paulo State, Brazil (Bauru Basin, Adamantina Formation, Upper Cretaceous). Journal of South American Earth Sciences 18: 1-10

97. Carvalho IS, Ribeiro LCB, Avilla LS (2004) Uberabasuchus terrificus sp. nov., a new Crocodylomorpha from the Bauru Basin (Upper Cretaceous), Brazil. Gondwana Research 7: 975-1002.

98. Estes R, Price LI (1973) Iguanid lizard from the Upper Cretaceous of Brazil. Science 180: 748-751

99. França MAG, Langer MC (2005) A new freshwater turtle (Pleurodira, Podocnemididae) from the Upper Cretaceous (Maastrichtian) of Minas Gerais, Brazil. Geodiversitas 27: 391-411.

100. Soares PC, Landim PMB, Fulfaro VJ, Sobreiro Neto AF (1980) Ensaio de caracterização do Cretáceo no Estado de São Paulo: Grupo Bauru. Revista Brasileira de Geociências 10: 177-185.
101. Dias-Brito D, Musacchio EA, Castro JC, Maranhão MSA, Suarez JM, et al. (2001) Grupo Bauru: uma unidade continental do Cretáceo do Brasil concepções baseadas em dados micropaleontológicos, isotópicos e estratigráficos. Revue Paléobiologique 20: 245-304.

102. Gobbo-Rodrigues SR, Coimbra JC, Petri S, Bertini RJ (2003) Kwango Serires (Congo), Bauru Group (Brasil) and Neuquén Basin (Argentina) ages, based on ostracodes and vertebrates. XVIII Congresso Brasileiro de Paleontologia. Brasilia. pp 152-153.

103. Zaher H, Pol D, Carvalho AB, Riccomini C, Campos DA, et al. (2006) Redescription of the cranial morphology of Mariliasuchus amarali, and its phylogenetic affinities (Crocodyliformes, Notosuchia). American Museum Novitates 3512: 1-40.

104. Santucci RM, Bertini RJ (2001) Distribuição paleogeográfica e biocronológica dos titanossauros (Saurischia, Sauropoda) do Grupo Bauru, Cretáceo Superior do sudeste brasileiro. Revista Brasileira de Geociências 31: 307-314.

105. Bonaparte JF (1991) Los vertebrados fósiles de la Formación Río Colorado, de la ciudad de Neuquén y cercanías, Cretácico Superior, Argentina. Revista del Museo Argentino de Ciências Naturales. pp 17-123.

106. Barcelos JH (1984) Reconstrução paleogeográfica da sedimentação do Grupo Bauru baseada na sua redefinição estratigráfica parcial em território paulista e no estudo preliminar fora do Estado de São Paulo. Rio Claro: UNESP. 190 p.

107. Fernandes LA (2004) Mapa litoestratigráfico da parte oriental da Bacia Bauru (PR, SP, MG), escala 1:1.000.000. Boletim Paranaense de Geociências 55.

108. Andrade MB, Bertini RJ, Pinheiro AEPC (2006) Observations on the palate and choanae structures in Mesoeucrocodylia (Archosauria, Crocodylomorpha): phylogenetic implications. Revista Brasileira de Paleontologia 9: 323-332.

109. Vasconcellos FM, Carvalho IS (2005) Estágios de desenvolvimento de Mariliasuchus amarali, Crocodyliformes Mesoeucrocodylia da Formação Adamantina, Cretáceo Superior da Bacia Bauru, Brasil. Anuário do Instituto de Geociências - UFRJ 28: 49-69.

110. Riff D, Kellner AWA (2001) On the dentition of Baurusuchus pachecoi Price Crocodyliformes, Metasuchia) from the Upper Cretaceous of Brazil. Boletim do Museu Nacional 59: 1-15.

111. Vasconcellos FM, Carvalho IS (2010) Paleoichnological assemblage associated with Baurusuchus salgadoensis remains, a Baurusuchidae Mesoeucrocodylia from the Bauru Basin, Brazil (Late Cretaceous). New Mexico Museum of Natural History and Science Bulletin 51: 227-237.

112. Nascimento PM (2008) Descrição morfológica e posicionamento filogenético de um Baurusuchidae (Crocodyliformes, Mesoeucrocodylia) do Cretáceo Superior da Bacia Bauru, região de General Salgado (SP). São Paulo: Universidade de São Paulo. 215 p.

113. Gasparini Z, Pol D, Spalletti LA (2006) An unusual marine crocodyliform from the Jurassic-Cretaceous boundary of Patagonia. Science 311: 70-73.

114. Brochu CA (1999) Phylogenetics, taxonomy, and historical biogeography of Alligatoroidea. Journal of Vertebrate Paleontology Memoir 6: 9-100.

115. Buscalioni AD, Sanz JL (1988) Phylogenetic relationships of the Atoposauridae (Archosauria, Crocodylomorpha). Historical Biology 1: 233-250.

116. Andrade MB, Bertini RJ (2008) A new Sphagesaurus (Mesoeucrocodylia: Notosuchia) from the Upper Cretaceous of Monte Alto City (Bauru Group, Brazil), and a revision of the Sphagesauridae. Historical Biology 20: 101-136.

117. Wu X-C, Sues H-D (1996) Anatomy and phylogenetic relationships of Chimaerasuchus paradoxus, an unusual crocodyliform reptile from the Lower Cretaceous of Hubei, China. Journal of Vertebrate Paleontology 16: 688-702. 


\section{Text S1.}

Characters previously proposed as unique for certain taxa are marked with an asterisk.

Cynodontosuchus rothi Woodward, 1896 . Museo de La Plata (MLP) 64-IV-16-25 -

Baurusuchid with notch at the premaxilla-maxilla contact for the reception of enlarged anterior dentary tooth anteroposteriorly enlarged but dorsoventrally low*, palatine bar flat with wide ventral face, absence of row of foramina flanking the medial contact of palatines, absence of enlarged premaxillary teeth.

Baurusuchus pachecoi Price, 1945. Museu de Ciências da Terra, Departamento Nacional de Produção Mineral (DGM) 299-R - Baurusuchid with lateral margins of squamosal and postorbital parallel to skull longitudinal axis, alveolar margin of the maxilla straight (in lateral view) posterior to the enlarged caniniform tooth, palatine bar with cylindrical dorsal portion and constricted posteriorly, maxilla-palatine suture V-shaped*, choanal septum transversally broad, ventral ridges of the basisphenoid sub-parallel.

\section{Stratiotosuchus maxhechti Campos, Suarez, Riff \& Kellner, 2001. DGM 1477-R -} orbital border, anterior and posterior palpebrals sutured without a foramen between them, frontal does not enter the supratemporal fossa*, enlarged foramen incisivum in premaxillamaxilla suture. A referred partial skull is reported for Stratiotosuchus Universidade Estadual Paulista, Rio Claro R 73 from Monte Alto, São Paulo, Brazil. This specimen presents some distinct morphological characters from the holotype, which were attributed to taphonomic distortions and ontogenetic variation. We have not analyzed this specimen firsthand; however, we point out some differences between this specimen and the holotype (e.g., the presence of a foramen between the palpebrals, presence of a small posttemporal fenestra and a non-ridged choanal 
septum) which vary among the phylogeny of Baurusuchidae proposed here. In addition, the referred specimen was collected more than $300 \mathrm{~km}$ from the holotype. This distance is bigger than any geographic range associated with undisputed Brazilian baurusuchids. Based on these concerns, we prefer to maintain only the holotype in our diagnosis and for OTU scoring.

Baurusuchus salgadoensis Carvalho, Arruda-Campos \& Nobre, 2005. Museu Histórico e Paleontológico de Monte Alto (MPMA)-62-0001-02 - Baurusuchid with paired ventral ridges of basisphenoid anteroventrally convergent and ridged border of the angular's medial surface does not overcome the anterior edge of the mandibular fenestrae*.

Wargosuchus australis Martinelli \& Pais, 2008. Museo Professor J. Olsacher -PV 6134 Baurusuchid with frontal-nasal contact, lacrimal duct placed ventrally to the corner formed by the dorsal and lateral lacrimal surfaces, dorsal surface of the anterior palpebral raised in relation to that of the prefrontal with a groove between those surfaces.

Baurusuchus albertoi Nascimento \& Zaher 2010 - Museu de Zoologia da Universidade de São Paulo -PV 140 - Baurusuchid with the descending expansion of the lateral edge of the squamosal anteriorly concave, well-developed ventromedial crest on the quadrate*. 


\section{Text S2.}

The OTUs used in the parsimony are listed below, along with data sources for the phylogenetic analysis. Pissarrachampsa sera was coded based on both LPRP/USP 0019 and LPRP/USP 0018. Holotypes and lectotypes are marked with an asterisk.

\section{Outgroup}

Notosuchus terrestris Woodward, 1896 - Museo de Geología y Paleontología, Universidad Nacional del Comahue (MUCP) 137, MUCP 147, Museo Argentino de Ciencias Naturales (MACN)PV-RN-1037; MACN-PV-RN-1038; MACN-PV-RN-1045, MLP-64-IV-16-5*.

Mariliasuchus amarali Carvalho \& Bertini, 1999 - Coleção de Paleontologia de Vertebrados da Universidade Federal do Rio de Janeiro (UFRJ) DG 50R*, UFRJ DG 105R, UFRJ DG 106 R.

Armadillosuchus arrudae Marinho \& Carvalho, 2009 - UFRJ DG 303R*, MPMA-64-0001-04.

Ingroup

Cynodontosuchus rothi Woodward, 1896 - MLP 64-IV-16-25*.

Baurusuchus pachecoi Price, 1945 -This taxon was scored only based on published descriptive accounts.

Stratiotosuchus maxhechti Campos, Suarez, Riff \& Kellner, 2001 - DGM 1477-R*.

Baurusuchus salgadoensis Carvalho, Arruda-Campos \& Nobre, 2005 - MPMA-62-0001-02*.

Wargosuchus australis Martinelli \& Pais, 2008 - Museo Professor J. Olsacher -PV 6134*.

Baurusuchus albertoi Nascimento \& Zaher 2010 - This taxon was scored only based on published descriptive accounts. 


\section{Text S3.}

Characters 5, 11, 12, 27 and 32 were treated as additive and are marked with a + , autapomorphies are marked with an asterisk.

1. Premaxilla-maxilla suture: in the lateral surface of rostrum (0), internalized in a notch for the reception of lower caniniform (1).

2. Nasals: paired (0), partially or complete fused (1).

3. Posterior portion of the nasal elevated above the dorsal surface of the maxillae, forming a sagittal bar: absent (0); present posteriorly (1). New character. Crocodyliformes in general have a smooth transition between the dorsal surface of the nasal and maxilla at the posterior portion of the rostrum, as found in Mariliasuchus, Hamadasuchus, and Crocodylus. However, within Baurusuchidae, the posterior portion of the nasal is markedly elevated in relation to the dorsal surface of the maxilla, forming an acute bar which tends to become less marked anteriorly, becoming confluent with the dorsal surface of the maxillae just anterior to the orbit.

4. Dorsal surface of the nasal, posterior portion: rounded or flat (0), bearing a rugose broad depression (1). New character. Usually in Crocodyliformes, the posterior portion of the nasals has a central portion that is at the same level, or above, the borders of the bone, as seen in Baurusuchus. On the other hand, Pissarrachampsa and Wargosuchus have the lateral borders of the posterior portion of the nasal elevated in relation to the central portion of the bone. In addition, the dorsal surface of their rostrum has a ventrally directed dorsal curvature. The combination of both characters with the highly rugose bone surface in this region forms an extensive rugose depression typical to those taxa.

5. Prefrontal-prefrontal medial contact (+): absent (with a broad contact between nasal and frontal) (0) medial margin of prefrontals anteriorly convergent, almost touching each other 
(with a tiny contact between nasal and frontal) or touching each other anteriorly (1), contact present along mostly of the dorsal medial edge (2). New character. Crocodyliformes in general have a broad contact between frontal and nasal (e.g., Mariliasuchus, Hamadasuchus, Sebecus, Crocodylus) preventing contact between the contralateral prefrontals, but baurusuchids have a median approximation of the prefrontal. In Pissarrachampsa and Wargosuchus the prefrontal approximation occurs only at the anterior portion of the bone, whereas the posterior region remains well separated. In Stratiotosuchus and Baurusuchus the prefrontals contact along mostly their medial margins.

6. *Dorsal surfaces of prefrontal and anterior palpebral: continuous (0), central portion of the dorsal surfaces elevated, with a marked groove between them (1). New character. In Wargosuchus the central portions of the dorsal surfaces of the palpebral and nasal are raised, forming a groove between the elements. In other baurusuchids (e.g., Pissarrachampsa, Stratiotosuchus) the central part of those bones are about the same level as the lateral and medial portions of the dorsal surface.

7. Frontal: participates in the supratemporal fenestrae (0), excluded from the supratemporal fenestrae (1).

8. Width of frontals between orbits relative to mid-length width across nasals: narrow (similar to width of nasals) (0); or broad (about twice the width of nasals) (1).

9. Dorsal surface of frontal, posterior to orbits: flat or slightly concave (0), or markedly concave transversely (1).

10. Midline longitudinal depression on anterior portion of frontal: absent (0), present (1). New character. The general condition of the frontal anterior surface is flat to rounded, as seen in Mariliasuchus and Baurusuchus pachecoi. Pissarrachampsa and Wargosuchus show a modified condition in which a conspicuous depression occurs along the midline of this region. 
A similar condition is also found in Calsoyasuchus valliceps and was previously termed the 'frontal dorsal valley'.

11. Frontal longitudinal ridge (+): absent (0), restricted to the posterior portion (1), extending anteriorly to the frontal mid-length (2).

12. Support for the anterior palpebral bone (+): marked depression on prefrontal (0), marked depression on prefrontal and lacrimal forming an incipient lateral projection (1), marked depression on prefrontal and lacrimal forming a great lateral projection for the support of anterior palpebral (2)..

13. *Supratemporal rims raised and hypertrophied: restricted to the median edge of the external supratemporal fenestra (0), extended to anterior edge of the external supratemporal fenestrae (1). New character. In baurusuchids, as seen in Stratiotosuchus, the median borders of the external supratemporal fenestrae are raised and hypertrophied, forming a rim. In Pissarrachampsa that rim is not limited to the medial border, but also extends anteriorly, following the lateral curvature of the anterior border of these openings and almost reaching the lateral contact between frontal and posterior palpebral.

14. Postorbital-quadratojugal contact in lateral view: restricted (0), broad contact between quadratojugal and the posterior portion of the postorbital descending flange (1).

15. Lateral surface of the postorbital descending flange: flat (0), or concave (1)._New character. The general condition of Crocodyliformes is a restricted postorbital descending flange, as seen in Crocodylus, or a flat well developed postorbital descending flange, as in Mariliasuchus. In baurusuchids, the well developed descending flange of the postorbital is markedly concave, as seen in Pissarrachampsa.

16. Postorbital-squamosal suture at the skull table in lateral view: straight line (0), squamosal anteriorly convex (1). 
17. Lateral margins of squamosal and postorbital in dorsal view: parallel (0), or diverging posteriorly (1).

18. Squamosal prongs: present (0), absent (1).

19. Squamosal lateral descending flange: obliquely directed (0), vertically directed with lateral edge medially concave and laterally convex (1), vertically directed and medially convex and laterally concave (2).

20. *Lacrimal duct external aperture: ventral to the corner formed by the dorsal and lateral lacrimal surfaces (0), at the corner (1). New character. The participation of the lacrimal in the structure that supports the anterior palpebral, as seen in Baurusuchidae(e.g., Wargosuchus), defines two surfaces of this bone. The lateral surface is continuous to the lateral surface of the rostrum, whereas the dorsal surface is perpendicular to the former, facing dorsally, and contacts the prefrontal lateral expansion. In Pissarrachampsa, the lacrimal duct opening is located on the lateral corner formed by those two surfaces, while in other taxa (e.g., Wargosuchus) the opening is located above the corner formed by the two planes.

21. *Contact between anterior and posterior palpebrals: only laterally, forming a supraorbital foramen (0), along the whole length without a foramen (1).

22. Alveolar margin of maxilla in lateral view: almost straight (0), arched only anteriorly, below the enlarged caniniform tooth (1), arched along the entire alveolar margin (2).

23. Maxillary palatal sagittal contact: smooth (0), bearing a longitudinal series of foramina (1)._New character. In general the maxillae palatal surface is flat and smooth (e.g., Crocodylus) or bears a longitudinal torus (e.g., Hamadasuchus). Derived Baurusuchidae show a modified condition, in which a series of longitudinal irregularly spaced foramina are placed at the median palatal contact of the maxillae, so that the foramina are bounded by both bones of the pair. 
24. Dorsoventral depth of the jugal orbital portion in relation to infratemporal portion: almost the same depth (0), orbital portion twice the depth of the infratemporal portion (1).

25. Dorsoventral depth of the jugal antorbital portion in relation to infraorbital portion: equal or lower (0), antorbital portion deeper than infraorbital portion (1).

26. *Posterior portion of the jugal orbital border: without a notch (0), with a marked ventral notch (1).

27. Jugal outer surface (+): confluent along the entire length (0), infratemporal portion of jugal laterally displaced but not reaching the level of orbital anterior edge (1), infratemporal portion of jugal laterally displaced and reaching the level of orbital anterior edge (2).

28. Jugal infratemporal bar: laterally flat (0), rod-shaped (1).

29. Anterodorsal ramus of quadrate in ventral view: developed, forming more than $50 \%$ of the lateral edge of the internal supratemporal fenestra (0), restricted, forming less than $50 \%$ of the lateral edge of the internal supratemporal fenestra (1). New character. In general the quadrate of Crocodyliformes emits a dorsal process extending medial to the postorbital descending flange and the quadratojugal dorsal process, which forms most of the lateral edge of the internal supratemporal fenestrae (e.g., Alligator). In Baurusuchidae such as Pissarrachampsa this process is less extensive anteriorly and does not medially cover the postorbital and quadratojugal. Accordingly, the postorbital and quadratojugal form most of the lateral edge of that opening.

30. *Ventral border of quadratojugal and quadrate (lateral view): continuous (0), quadratojugal ventrally displaced, forming a notch between the bones (1). New character. Crocodyliformes usually posses a continuous ventral margin of the temporal area, formed by the quadratojugal and jugal (e.g.; Mariliasuchus, Baurusuchus pachecoi). In Pissarrachampsa, 
on the other hand, the ventral margin of the quadratojugal is more ventrally expanded, so that a notch is formed just posterior to the quadratojugal where it meets the quadrate.

31. Anterior margin of distal portion of body of the quadrate: at a right angle to the anterolateral portion of the bone (0), slopes gently towards the anterolateral portion of the bone (1). New character. In Crocodyliformes with a verticalized distal body of the quadrate, the transition between this portion of the bone and its anterolateral portion is abrupt, forming an almost right angle, as in Armadillosuchus and Mariliasuchus. In Baurusuchidae (e.g., Pissarrachampsa), the anterior face of the quadrate distal body slopes gradually to the anterior portion of the bone, forming a smooth transition between these two regions of quadrate.

32. Quadratojugal dorsal ramus in medial view (+): ending ventrally, or at the same level, of the dorsal tip of laterotemporal fenestra (0), overcoming the dorsal tip of laterotemporal fenestra but not reaching the supratemporal fossa (1), overcoming the dorsal tip of laterotemporal fenestra and reaching the supratemporal fossa (2). New character. The quadratojugal of Crocodyliformes possesses a dorsally directed ramus that overlaps the quadrate medially and borders the infratemporal fenestrae. The dorsal extension of this ramus varies among the studied taxa and does not symmetrically matches the lateral exposure of the bone. In Baurusuchinae (e.g.; Stratiotosuchus), the medial face does not overcomes the dorsal tip of the infratemporal fenestrae, whereas in the other taxa the medial face overcomes that dorsal tip (as seen in Armadillosuchus). In Pissarrachampsa, this condition is exaggerated so that the medial face reaches the ventral margin of the supratemporal fossa.

33. Quadrate lateral depression: absent (0), present with the major axis dorsoventrally oriented (1), present with the major axis anteroposteriorly oriented and with quadratojugalquadrate suture within the depression (2).

34. Quadrate fenestrae: visible in lateral view (0), internalized in otic notch (1). New character. Additional quadrate fenestrae are commonly found in Crocodyliformes, arranged 
around the otic aperture, as seen in the protosuchian Zosuchus davidsoni and in

Pissarrachampsa. In Baurusuchinae (e.g., Stratiotosuchus) the margin of the otic notch is more developed, encompassing the region of the additional quadrate fenestrae and hiding those apertures so that only the anterior one is partially visible in lateral view.

35. Lateral quadrate condyle: almost as anteroposteriorly wide as the medial condyle (0), or lateral quadrate condyle hemispherical (1). New character. In general, the anteroposterior extension of the medial and lateral quadrate condyles are subequal, as seen in Notosuchus. However, in some of the analyzed taxa (e.g.: Baurusuchus salgadoensis) the lateral condyle is enlarged in relation to the medial condyle, and has a hemispherical appearance in ventral view.

36. Muscle scar in the medial quadrate surface (ridge ' $A$ '): curved or almost straight (0), sigmoidal (1). New character. The muscle scar located at the ventromedial surface of the quadrate, associated to 'ridge $A^{\prime}$ of eusuchians, possesses a straight to curved profile in basal Mesoeucrocodylia, as in Baurusuchus salgadoensis. In some of the studied taxa (e.g., Pissarrachampsa) this structure assumes an evident sigmoidal profile, with the anteroventral orientation of its main axis.

37. Supraoccipital dorsal exposure: along the midline portion of posterior region of skull table (0), restricted to a thin surface attached to the posteriormost portion of parietal and squamosal (1). New character. The supraoccipital dorsal exposure on the skull roof varies in different Crocodyliformes groups, ranging from its total absence (e.g., Hamadasuchus) to a great median dorsal extension (e.g., Notosuchus). In Baurusuchidae (e.g., Pissarrachampsa sera and Baurusuchus salgadoensis), the supraoccipital assumes a unique morphology, and has a restricted thin transversal exposure in the posteriormost region of the skull roof. This exposure possesses the same anteroposterior thickness for its whole length until the inflexion point of the bone towards the occipital plane of the skull. 
38. Posterior region of the auditory fossa: posteriorly open (0), bound posteriorly by a posteroventrolateral extension of the squamosal and exoccipital (1).

39. Foramen incisivum: absent or small (0), enlarged (1). New character. The presence, as well the relative size of the incisivum foramen in the premaxilla-maxilla suture varies greatly among Crocodyliformes. Within the analyzed taxa, this structure is absent ( e.g., Mariliasuchus) or relictual (e.g., Baurusuchus pachecoi) in most taxa, but well developed in Cynodontosuchus and Stratiotosuchus.

40. Anterior extension of palatine: passes the anterior margin of the suborbital fenestrae (0), does not reach the level of the anterior margin of suborbital fenestrae (1). New character. Crocodyliformes in general has the palatine extending anterior to the anterior border of the suborbital fenestra. This extension can have different shapes, ranging from just a small anterior projection (e.g., Alligator) to a much broader structure, so that the palatine borders most of anterior margin of this opening (e.g., Hamadasuchus). In Baurusuchidae the palatine-maxilla suture is located posterior to the anterior margin of the suborbital fenestrae (e.g., Cynodontosuchus, Pissarrachampsa, Baurusuchus pachecoi), and the palatine does not contribute to the anterior margin of this aperture.

41. Ventral face of palatine bar: flat and wide (0), ventral surface restricted and dorsal portion cylindrical with the same wideness through (1) ventral surface restricted and dorsal portion cylindrical constricted in the posterior portion (2). New character. Usually for Mesoeucrocodylia the palatine bar has a large flat ventral surface that does not allow the observation of the dorsal portion of the bone in ventral view as seen in eusuchians (e.g., Alligator) and Cynodontosuchus. On the other hand, in advanced baurusuchids, the ventral surface of palatine is restricted to a narrow surface, and the dorsal cylindrical portion of the bone is ventrally apparent (e.g., Pissarrachampsa, Baurusuchus pachecoi). Furthermore, the dorsal cylindrical surface can have the same wideness through (e.g., Pissarrachampsa) or be 
constricted at its posterior portion, near the palatine posterolateral divergent rami (e.g., Baurusuchus salgadoensis).

42. Medial palatal contact: smooth (0), rugose (1). New character. The medial contact of the palatines in Crocodyliformes is usually flat (e.g., Cynodontosuchus, Lomasuchus) or often somewhat sulcate (e.g., Alligator mississipiensis), but in Baurusuchia that contact is distinctly raised, forming a ridged rugose suture along its whole extension.

43. *Dorso-lateral surface of the ectopterygoid near jugal contact: smooth (0), bearing a series of irregularly-sized foramina (1). New character. The ectopterygoid of most analyzed taxa has a robust constitution, with a large and generally smooth lateral surface that curves dorsolaterally to meet the jugal (e.g., Mariliasuchus, Baurusuchus albertoi). Pissarrachampsa, on the other hand, shows a series of irregularly-sized foramina at this broad laterally exposed surface.

44. Row of foramina flanking the medial contact of the palatines: absent (0), present (1). New character. The palatine bar of Crocodyliformes usually has a smooth ventral surface (e.g., Mariliasuchus, Cynodontosuchus). The restricted ventral surface of that bar in some baurusuchids bears a series of foramina located in a pair shallow grooves flanking the median contact of the bones (e.g., Pissarrachampsa sera, Baurusuchus pachecoi). These foramina are regularly spaced and follow, for a short distance, the lateral curvature of the palatal posteroventral divergent rami where both grooves become confluent.

45. Ridge on the ectopterygoid-jugal articulation: absent (0), present and continuous with the ventral ridge of the infratemporal portion of jugal (1), present but separated from the ventral ridge of the infratemporal portion of jugal by a notch at the posterior margin of the articulation (2)._New character. Usually for Crocodyliformes the jugal-ectopterygoid contact is flat and located in the ventral surface of the skull (e.g., Hamadasuchus, Mariliasuchus). Baurusuchids posses the jugal-ectopterygoid suture located laterally in the skull. In addition, 
the contact between these bones is markedly ridged, partially because of the dorsolateral curvature of the ectopterygoid, and partially due to the more robust ventral margin of the jugal. This ridged suture extends along the ventral portion of cheek area and is either continuous with the laterally displaced ridge of the infratemporal ramus of the jugal (e.g., Baurusuchus pachecoi) or separated (e.g., Pissarrachampsa) by a notch at the posteriormost region of the ectopterygoid-jugal suture.

46. *Ectopterygoid-jugal contact behind pterygoid wing in ventral view: rounded (0), medially angled (1). New character. The ectopterygoid body in derived Notosuchia, including Baurusuchidae, is a anteromedially oriented, robust element. Its posterior end is rounded in most taxa (e.g., Stratiotosuchus), but in Pissarrachampsa, the posterior portion of the ectopterygoid-jugal suture forms a square angle between a medially directing segment perpendicular to the jugal main axis.

47. Ventral surface of the choanal septum: smooth (0), ridged (1). New character. The choanal septum of most of the analyzed taxa has a flat to rounded ventral surface, which is the variation found in most crocodyliforms (e.g., Mariliasuchus, Pissarrachampsa sera, Sebecus querejazus). In B. pachecoi and Stratiotosuchus, on the other hand, the central portion of the septum is markedly ridged and ventrally displaced relative to the adjacent regions.

48. Major surface of the pterygoid wing: lateroventrally oriented (0), ventrally oriented (1). New character. The pterygoid wing of Crocodyliformes is usually a flat structure with its main surface ventrally directed (e.g., Mariliasuchus, Pissarrachampsa, Alligator mississipiensis). However, in the species of Baurusuchus, the pterygoid wing is anteriorly twisted, so that the main surface is anterolaterally directed. This peculiar orientation makes the ectopterygoid as anteroposteriorly long as the pterygoid.

49. Posttemporal fenestrae: present (0), absent (1). New character. The size and location of the posttemporal fenestrae in Crocodyliformes varies across different group, probably with 
multiples gain/loss events. Within the analyzed taxa, it is either absent (e.g., Notosuchus, Pissarrachampsa) or found as a small opening (e.g., Mariliasuchus amarali, Baurusuchus pachecoi).

50. Pterygoid parachoanal fenestra and depressions: absent (0), present (1).

51. Basisphenoid ventral surface: continuous to surrounding bones (0), ventrally displaced and separated from the neighboring elements by a posteroventral step formed by a groove that separated the bone from the main occipital plane (forming a postchoanal pterygoidbasisphenoid tuberosity) (1). New character. The basisphenoid ventral exposure varies greatly within Crocodyliformes. In the analyzed taxa, as well as in other basal Mesoeucrocodylia, the basisphenoid is largely exposed ventrally. In the outgroup taxa (e.g., Armadillosuchus), the ventral surface of the bone is confluent with the other neurocranial bones, whereas in Baurusuchidae (e.g., Pissarrachampsa sera, Baurusuchus salgadoensis) its central portion is ventrally projected, forming a step between this surface and that of the surrounding bones. Because of this ventral projection, the basisphenoid is delimited by a tuberosity that is especially developed anteriorly and termed here as the postchoanal pterygoid-basisphenoid tuberosity.

52. Anterior wall of the lateral Eustachian foramina: present, separating each foramen from the sulcus (0), absent, foramina open into the sulcus (1). New character. The lateral Eustachian foramina are usually bordered anteriorly by a wall formed by the basisphenoid alone (e.g., Mariliasuchus), or by the suture of that bone with the pterygoid (e.g., Araripesuchus wegneri, Montealtosuchus). In some of the analyzed taxa (e.g., Armadillosuchus, Pissarrachampsa sera, Baurusuchus salgadoensis) this anterior wall is absent and the aperture of each lateral Eustachian foramina faces anterolaterally instead of strictly ventrally.

53. Lateral Eustachian foramen: smaller than medial one (0), as large or larger than medial one (1). New character. In most Crocodyliformes the median Eustachian foramen is larger than 
the lateral elements (e.g., Alligator), as also seen in part of the analyzed outgroup (e.g., Notosuchus) and ingroup (e.g., Baurusuchus salgadoensis). On the other hand, Armadillosuchus and Pissarrachampsa posses enlarged lateral Eustachian foramina, which are more developed than the medial one.

54. Paired ridges located medially on the ventral surface of the basisphenoid (originating at the anterior margins of lateral Eustachian foramina): absent (0), present and anteroventrally convergent (1), present and sub-parallel (2).

55. Tooth mesial and distal carinae: smooth (0), bearing a pebbled surface (1), serrated (2).

56. Premaxillary teeth: four (0), three (1).

57. *Enlarged premaxillary teeth: present (0), absent (1).

58. Last premaxillary tooth hypertrophy: present (0), absent (1).

59. *Maxillary teeth: five or more (0), only four (1).

60. Mandibular outer surface sculpture: present on dentary (0), present on dentary and splenial (1). New character. Ornaments on the anterior mandibular outer surface are usually restricted to the dentary in Crocodyliformes (e.g., Notosuchus, Alligator), but in some of the analyzed taxa the ventral (outer) surface of the splenial is also sculptured (e.g., Pissarrachampsa sera, Baurusuchus salgadoensis).

61. Foramen intramandibularis oralis: small or absent (0), big and slot-like (1).

62. Mandibular symphysis, orientation of anterior part: horizontal or slightly dorsally directed (0), forming an angle of approximately 45 degrees to the main axis of the jaw (1).

63. Peg at the posterior surface of the mandibular symphysis formed by a ridged splenial suture: absent (0), present (1). 
64. Posteroventral symphyseal depressions: absent (0), present (1). New character. The common condition found in basal Crocodyliformes is a vertically oriented splenial forming the posterior surface of the jaw symphysis (e.g., Notosuchus, Alligator mississipiensis). Yet, in various Mesoeucrocodylia the splenial enters ventral surface of the jaw (e. g., Montealtosuchus), but only in Baurusuchidae this area bears two distinct depressions (e.g., Cynodontosuchus, Pissarrachampsa, Baurusuchus salgadoensis). One depression is located at the level of dentary-splenial suture, dorsally displacing the entire posteroventral surface of the splenial. A second depression is located at the posteroventral surface of the splenial, displacing the posterior half of this surface more dorsally.

65. M. pterygoideous posterior insertion: reaching the anterior external mandibular fenestra (0), in a marked depression on surangular-angular lateral surface on posterior edge of external mandibular fenestra (1).

66. * Ridged border of the angular medial face: overcomes the anterior edge of the mandibular fenestra (0), does not overcome the anterior edge of mandibular fenestra (1). 


\section{Text S4.}

Character states (0-2) are given for outgroup and ingroup taxa. Brackets enclose variable conditions; question mark indicates missing data; and a dash indicates inapplicability due to extreme transformation.

Notosuchus terrestris

00000?1000 200000000- 1000-00000 0?000?0000 00?00?01100000000000 $00000 ?$

Mariliasuchus amarali

$000000100001000\{01\} 00001000-0100001001-000000000001010000100100001000$

Armadillosuchus arrudai

01000000000100111000 -????01110 01001100 ?? ?????????? 01101????? ??1???

Cynodontosuchus rothi

1????????? ?????????? ?\{1 2\}???????? ????????11 00?0?????? ????211-0? ?111??

Wargosuchus australis

11?111???1 ?2???????0 ?????????? ?????????? ?????????? ????2?00?? ??????

Pissarrachampsa sera

$111110001122111\{0$ 1\}11\{1 2\}1 121100211112200111 ?1 111121011111122100111111 ??

Stratiotosuchus maxhechti

1100201110120110111002110121101011001111 1???201?1? ??0?210001 1?11??

Baurusuchus albertoi 
?????????? ???111112? 1??11021?0 101110?1?? ??0?2??0?? ?????????? ????10

Baurusuchus pachecoi

11???????? ???11101\{1 2\}? ?1111021?0 101110?101 21?11?100? 11?220010? 111?10

Baurusuchus salgadoensis

1110200110120111111012 ?11021101011101101 21011??00? 1101200101111111 
Text S5.

List of apomorphic states by node for the minimum-length tree in the maximumparsimony analysis (Figure 17). Delayed transformations are indicated with an asterisk.

Armadillosuchus + Baurusuchidae

$2(1), 7(0), 15(1), 17(1), 28(1), 29(1), 52(1)$.

Baurusuchidae

$1(1) ; 22(2) ; 40(1)^{*} ; 55(2) ; 56(1)^{*} ; 62(1)^{*} ; 64(1)^{*}$

Pissarrachampsinae + Baurusuchinae

$5(1)^{*}, 9(1)^{*}, 12(2)^{*}, 14(1)^{*}, 18(1)^{*}, 19(1)^{*}, 23(1)^{*}, 24(1)^{*}, 27(2)^{*}, 31(1)^{*}, 33(1)^{*}, 37(1)^{*}$, $38(1)^{*}, 41(1), 42(1) ; 44(1), 45(1)^{*}, 51(1)^{*}, 54(1)^{*}, 60(1)^{*}, 61(1)^{*}$.

Pissarrachampsinae

$4(1), 5(1), 10(1)$.

Baurusuchinae

5(2), 8(1), 11(1)*, 32(0), 33(1)*, 34(1), 36(0), 47(1).

Baurusuchus

$25(1), 48(0)^{*}, 65(1)^{*}$

B. pachecoi + B. salgadoensis

$45(1), 41(2) *, 56(0) *, 58(1)$ 